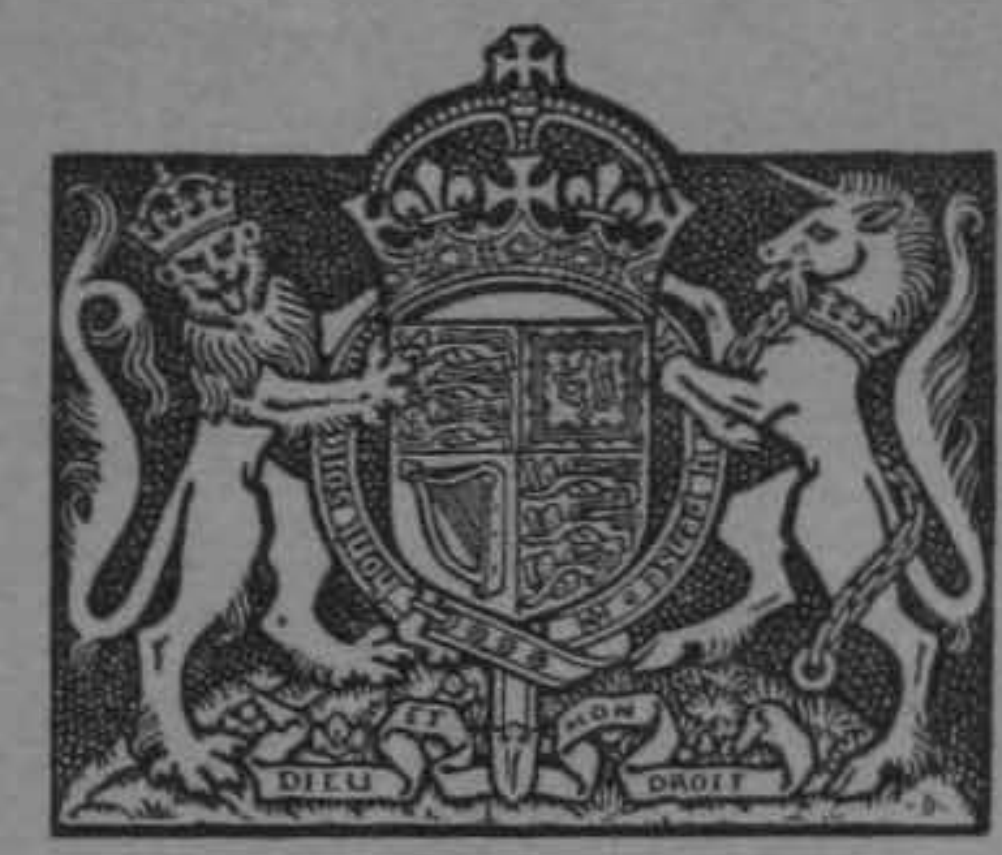

Treaty Series No. 1 (1953)

\title{
International Convention for the Safety of Life at Sea, 1948
}

London, 10th June, 1948

[The Convention was accepted by the Government of the United Kingdom on 30th September, 1949]

Presented by the Secretary of State for Foreign Aflairs to Parliament by Command of Her Majesty

January 1953

\section{LONDON \\ HER MAJESTY'S STATIONERY OFFICE \\ PRICE 6S. 6d. NET}

Cind. 8720 


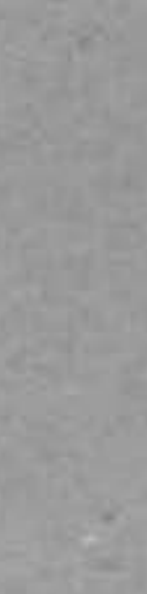

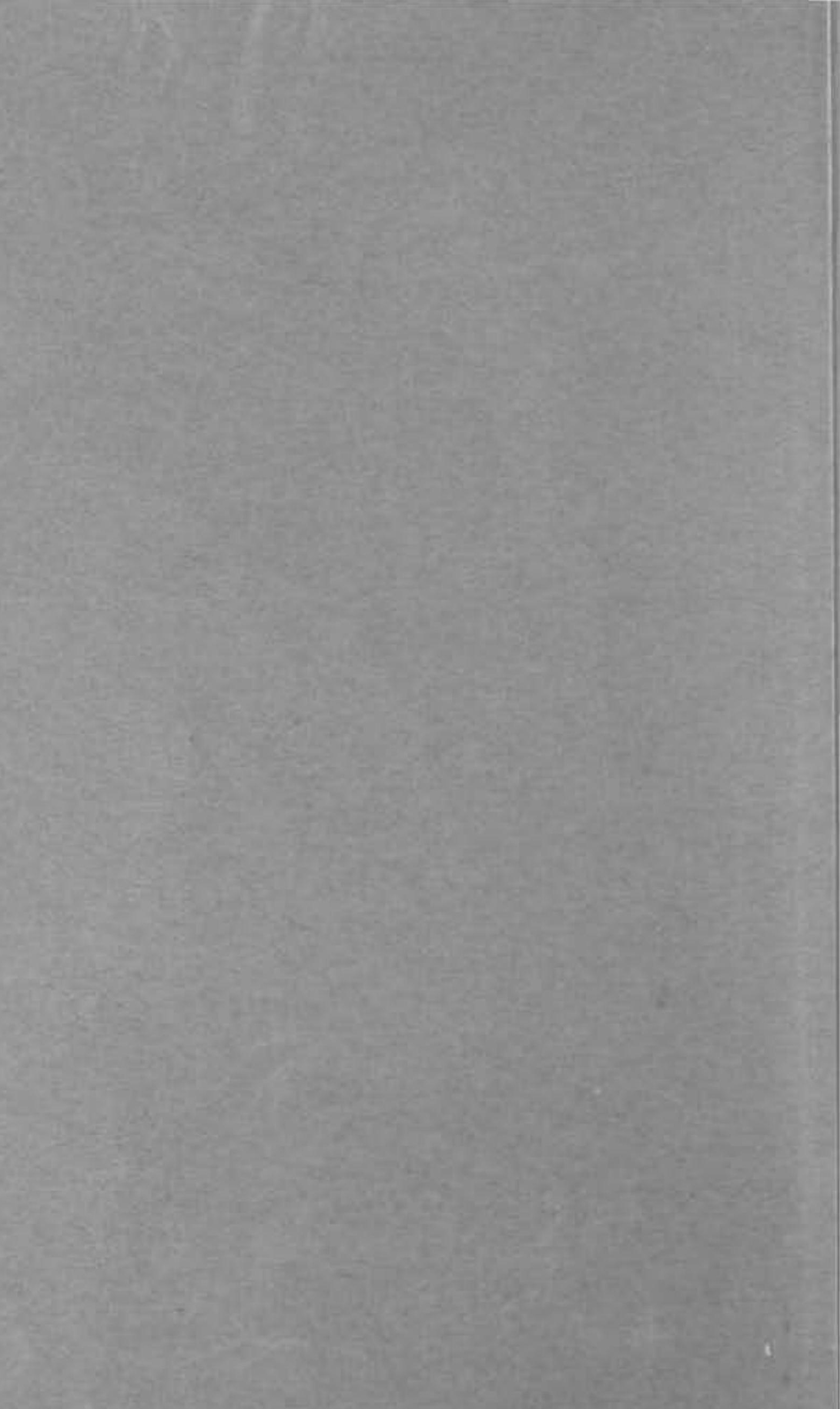




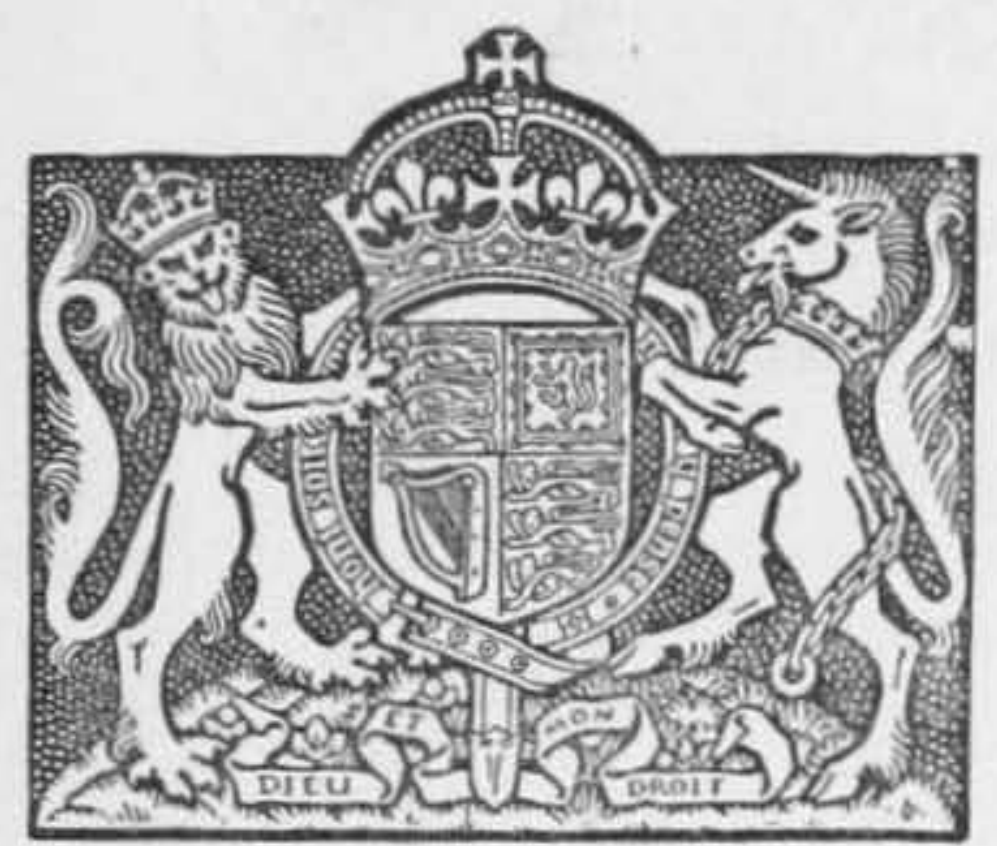

Treaty Series No. 1 (1953)

\section{International Convention for the}

\section{Safety of Life at Sea, 1948}

London, 10th June, 1948

[The Convention was accepted by the Government of the United Kingdom on 30th September, 1949]

Presented hy the Secretary of State for Foreign AlJuirs to Parliament by Command of Her Majesiy

January 1953

$-$

LONDON

HER MAJESTY'S STATIONERY OFFICE PRICE 6s. 6d. NET

Cind. 8720 



\section{International Convention for the Safety of Life at Sea, 1948}

INDEX

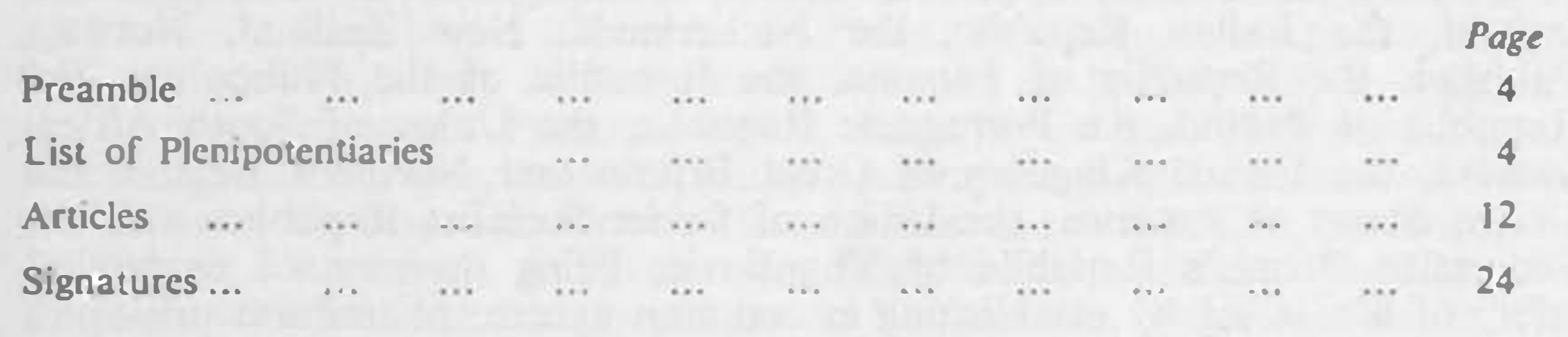

Regulations-

Chapter I.-General Provisions

Part A.-Application, Definitions, \&c. $\quad$.. 28

Part B.-Surveys and Cerificates ...

$\begin{array}{lllllll}\text { Part C.-Casualties ... } & \ldots & \ldots & \ldots & \ldots & 40\end{array}$

Chapter II.-Construction

$\begin{array}{lllllll}\text { Part A.-General } & \ldots & \ldots & \ldots & \ldots & \ldots & 42\end{array}$

Part B.-Subdivision and Stability $\quad \ldots \quad \ldots \quad$.. 44

Part C.-Electrical Installations ...

Part D.-Fire Protection in Accommodation and

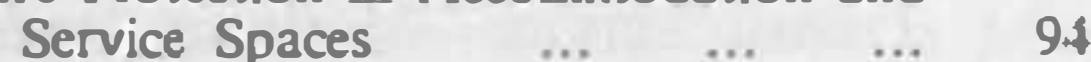

Part E.-Fire Detection and Extinction in Passenger Ships and Cargo Ships ... 114

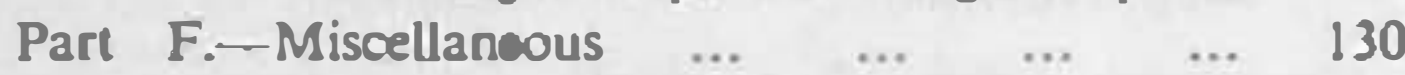

Chapter III.-Life Saving Applianoes, \&c.

$\begin{array}{lllllll}\text { Part A.-General } & \ldots & \ldots & \ldots & \ldots & \ldots & 132\end{array}$

Part B.-Passenger Ships only $\quad \ldots \quad$... $\quad \ldots \quad 152$

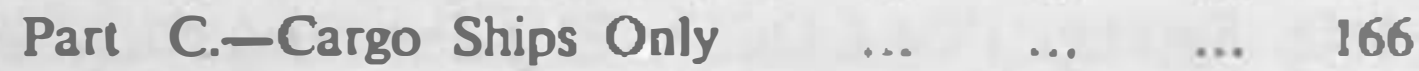

Chapter IV.-Radiotelegraphy and Radiotelephony

Part A.-Application and Definitions ... $\quad \ldots \quad 170$

$\begin{array}{lllllll}\text { Part B. }- \text { Watches ... } & \ldots & \ldots & \ldots & \ldots & 172\end{array}$

Part C.-Technical Requirements $\quad \ldots . \quad \ldots \quad 176$

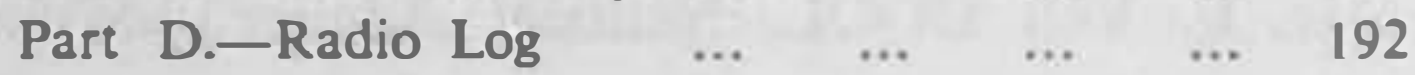

$\begin{array}{lllllll}\text { Chapter V.-Safety of Navigation } & \ldots & \ldots & \ldots & \ldots & 194\end{array}$

Chapter VI._Carriage of Grain and Dangerous Goods ... $\quad \ldots \quad 212$

$\begin{array}{llllllllll}\text { Certificates } & \ldots & \ldots & \ldots & \ldots & \ldots & \ldots & \ldots & \ldots & 218\end{array}$

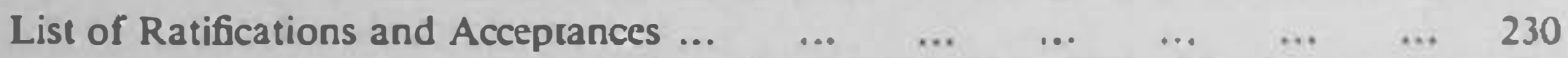




\section{INTERNATIONAL CONVENTION FOR THE SAFETY OF LIFE AT SEA, 1948}

London, JOih June, 1948

The Governments of the Argentine Republic, the Commonwealth of Australia, Belgium, the Republic of the United States of Brazil, Canada, the Republic of Chile, the Republic of China, Denmark, Egypt, the Republic of Finland, the Frcnch Republic. Greece, the Republic of Iceland, India, Ireland, the Italian Republic, the Netherlands, New Zealand, Norway. Pakistan, the Republic of Panama, the Republic of the Philippines, the Republic of Poland, the Porluguese Republic, the Union of South Africa, Sweden, the United Kingdom of Great Britain and Northern Ireland, the United States of America, the Union of Soviet Socialist Republics and the Federative People's Republic of Yugoslavia, being desirous of promoting safety of life at sea by establishing in common agreement uniform principles and rules directed thereto:

Considering that this end may best be achieved by the conclusion of a Convention to replace the International Convention for the Safety of Life at Sea, 1929:

Have appointed their Plenipotentiaries, namely:-

The Argenuine Republic

Captain Don Alberto J. ODDERA, Naval Attaché, Argentine Embassy, London.

Commander Don Juan Eugenio PEFFABET. Chief of Regime and Safety of Navigation Services Division in the Maritime and River Transit Service-Maritime Prefecture-Navy Department.

Lieutenant Don Jorge R. MARTINEZ-VIVOT, Naval Engineer, Navy Department.

The Commonwealth of Australia

Captain Norman Gerald ROSKRUGE. Acting Director of Navigation, Marine Branch, Deparıment of Shipping and Fuel.

Mr. Sydney POLLOCK, Engineer and Ship Surveyor-in-Chief, Marine Branch, Department of Shipping and Fuel.

Belgium

Mr. G. BERTRAND, Engineer in Chief. Director of the Marine Administration.

Mr. F. Van GOOL, Nautical Adviser, Marine Administration.

The Republic of the United States of Brazil

Vice-Admiral Gusiavo GOULART (Retd.). President, Maritime Tribunal.

Rear-Admiral Antonio Alves CAMARA, Director-General, Hydroglaphic and Navigation Department in the Ministry of the Navy.

Captain Paulo Nogueira PENIDO, Naval Attaché, Brazilian Embassy.

Commander J. C. Rego MONTEIRO. Naval Constructor. Head of the Technical Division, Rio de Janeiro Naval Yard. 


\title{
CONVENTION INTERNATIONALE POUR LA SAUVEGARDE DE LA VIE HUMAINE EN MER, 1948
}

\author{
Londres, le 10 juin 1948
}

Les Gouvernements de la République Argentine, du Commonwealth d'Australie, de la Belgique, de la République des Etats-Unis du Brésil, du Canada, de la République du Chili. de la République de Chine. du Danemark, de l'Egypte, de la République de Finlande, de la République française, de la Grèce. de la République d'Islande, de l'Inde, de l'Irlande, de la République italienne, des Pays-Bas, de la Nouvelle Zélande, de la Norvège, du Pakistan, de la République de Panama, de la République des Philippines, de la République de Pologne, de la République portugaise, de l'Union Sud-Africaine. de la Suède, du Royaume-Uni de Grande-Bretagne et d'lrlande du Nord, des Etats-Unis d'Amérique, de l'Union des Républiques socialistes soviétiques et de la République fédérative populaire de Yougoslavie, désireux d'établir d'un commun accord des principes et des règles uniformes à l'effet de sauvegarder la vie humaine en mer:

Considérant que le meilleur moyen d'atteindre ce but est la conclusion d'une Convention destinée à remplacer la Convention de 1929 pour la Sauvegarde de la Vie Humaine en Mer :

Ont désigné les Plénipotentiaires suivants:

Le Gouvernement de la République Argentine:

Le Capitaine de vaisseau Don Alberto J. ODDERA. Attaché Naval près l'Ambassade de la République Argentine à Londres.

Le Capitaine de frégate (R) Don Juan Eugenio PEFFABET. Chef de division des Services du Régime et de la Sécurité de la Navigation maritime et fluviale-Préfecture Maritime-Ministère dc la Marine.

Lieutenant Ingénieur Constructeur naval Don Jorge R. MARTINEZVIVOT, Ministère de la Marine.

Le Gouvernement du Commonwealth d'Australie:

Le Capitaine de vaisseau Norman ROSKRUGE, Directeur par intérim de la Navigation, branche maritime, Ministc̀re de la Navigation et des Combustibles.

Mr. Syciney POLLOCK. Ingénieur et Inspecteur en Chef des Navires. branche maritime. Ministère de la Navigation et des Combustibles.

Le Gouvernement belge:

Monsieur G. BERTRAND, Ingénieur en Chef, Directeur à l'Administration de la Marine.

Monsieur F. Van GOOL, Conseiller Nautique à l'Administration de la Marine.

Le Gouvernement des Etats-Unis de Brésil:

Le Vice-Amiral Gustavo GOULART (R). Président du Tribunal Maritime.

Le Contre-Amiral Antonio Alves CAMARA. Directeur général du Département de l'hydrographic et de la Navigation au Ministère de la Marine.

Le Capitaine de vaisseau Paulo Nogueira PENIDO. Attaché Naval près l'Ambassade des Etats-Unis du Brésil.

Commandant J. C. Rego MONTEIRO, Constructeur naval, chef de la division technique-Arsenal à Rio de Janeiro. 


\section{Canada}

Mr. Jules LEGER, Officer of the High Commissioner for Canada in London.

Mr. H. V. ANDERSON, Director of Marine Services.

The Republic of Chile

Commander Kaare OLSEN, Naval Attaché, Chilean Embassy, London.

\section{The Republic of China}

His Excellency Dr. Tien-Hsi CHENG, Ambassador.

\section{Denmark}

Mr. Ove NIELSEN, Head of Shipping Department, Royal Ministry of Trade, Industry and Shipping.

Mr. Aage H. LARSEN, Principal, Technical Section, Royal Ministry of Trade. Indusiry and Shipping.

Mr. Arnold POUlSEN, Civil Engineer, Adviser to the Royal Ministry of Trade, Industry and Shipping on Radio and Electrical Technique.

Mr. A. BACHE. Deputy Head of Section, Royal Ministry of Trade, Industry and Shipping. Secretary to the Delegation.

Mr. T. C. CHRISTENSEN, Shipowner. Member of the Board of Directors of the Danish Steamship Owners' Association.

Captain Th. PETERSEN, Secretary, Danish Steamship Owners' Association.

Captain J. Kastrup OLSEN, Chairman, General Danish Association of Master Mariners.

Mr. H. RASMUSSEN, Manager of the Firemen's Union of Denmark.

Egypt

Mr. Choukry Costandi FANOUS, Consul-General for Egypt in London.

The Republic of Finland

Captain William SÜDERMAN, Head of Marine Department of the Board of Navigation.

The French Republic

Mr. G. ANDUZE-FARIS. Secretary-General of the Merchant Marine.

\section{Greece}

Capiain Antoine BACHAS, R.H.N.F., Greek Ministry of Mercantile Marine, London.

The Republic of Iceland

His Excellency Mr. Stefan THORVARDSSON, Icelandic Minister to Great Britain.

\section{India}

Mr. V. K. Krishna MENON, High Commissioner for India in the United Kingdom.

Sir Raghavan PILLAI, Indian Chargé d’Affaires, Paris. 
Le Gouvernement du Canada:

Mr. Jules LEGER, Etat-Major du Haut-Commissaire à Londres.

Mr. H. V. ANDERSON, Directeur des Scrvices de la Marine.

Le Gouvernement du Chili:

Le Commandant Kaare OLSEN, Attaché Naval près l'Ambassade du Chili à Londres.

Le Gouvernement de la République de Chine:

Son Excellence le Dr. Tien-Hsi CHENG, Ambassadeur.

Le Gouvernement du Danemark:

Mr. Ove NIELSEN, Directeur des Services de la Marine Marchande, Ministère Royal du Commerce, de l'Industrie et de la Marine Marchande.

Mr. Aage H. LARSEN, Chef de la Section Technique, Ministère Royal du Commerce, de l'Industrie et de la Marine Marchande.

Mr. Arnold POULSEN, Ingénieur Civil, Conseiller technique en matière de radiotélégraphie et d'électricité, Ministère du Commerce.

Mr. A. BACHE, faisant fonction de Chef de Section, Ministère Royal du Commerce, de l'Industrie et de la Marine Marchande. Secrétaire de la Délégation.

Mr. T. C. CHRISTENSEN, Armateur, membre du Comité des Armateurs Danois.

Le Capitaine Th. PETERSEN, Secrétaire du Comité des Armateurs Danois.

Le Capitaine J. Kastrup OLSEN. Président de l'Association Génćrale Danoise des Capitaines de la Marine Marchande.

Mr. H. RASMUSSEN, Secrétaire Général du Syndicat des Chauffeurs.

Le Gouvernement de l'Egypte:

M. Choukry Costandi FANOUS, Consul Général d'Egypte à Londres.

Le Gouvernement de la République de Finlande:

Le Capitaine William SUDERMAN, Directeur de la Marine au Ministère de la Navigation.

Le Gouvernement de la République française:

Monsieur G. ANDUZE-FARIS, Secrétaire Général de la Marine Marchande.

Le Gouvernement de la Grèce:

Le Capitaine de vaisseau Antoine BACHAS, Ministère hellénique de la Marine Marchande, Londres.

Le Gouvernement d'Islande:

Son Excellence M. Stefan THORVARDSSON, Ministre d'Islande en Grande-Bretagne.

Le Gouvernement de l'Inde:

Mr. V. K. Krishna MENON, Haut-Commissaire pour l'Inde dans le Royaume-Uni.

Sir Raghavan PILLAI, Chargé d'Affaires pour l'Inde à Paris. 
Mr. M. A. MASTER, General Manager, Scindia Steam Navigation Company, Limited, Bombay.

Mr. R. S. MANI, Deputy High Commissioner for India in the United Kingdom.

Captain S. A. T. BULLOCK, Nautical Adviser, Government of India.

Lieutenant Commander T. B. BOSE, R.I.N., Principal Engineer and Ship Surveyor, Mercantile Marine Department, Calcutta.

Ireland

Mr. Denis DEVLIN, First Counsellor, Office of the High Commissioner for Ireland.

Miss Thekla J. BEERE, Principal Offcer, Department of Industry and Conmerce.

The Iralian Republic

Lieutenant-Gcneral of the Captains of the Port Giulio INGIANNI, Former Director-General of the Mercantile Marine. Chairman of the Italian Safety of Navigation Committee.

The Netherlands

Mr. P. S. van't HAAFF, Inspector-General of Shipping.

Mr. A. J. W. van ANROOY, Chief of the Mobile Telegraphy and Radiotelephony Services.

Captain G. J. BARENDSE, Former Commodore of the Holland-America Line.

Captain J. F. van MUIJLWIJK, Treasurer of the Merchant Navy Captains' and Officers' Union.

Mr. E. SMIT FZN, Naval Architect, Adviser to the Shipping Inspection Service.

Mr. D. HUDIG, Former Director of the Royal Netherlands Steam Navigation Company.

Mr. T. M. PELLINKHOF, Chief of Labour Section of the DirectorateGeneral of Shipping.

New Zealand

Engineer Lieutenant-Commander Edward BROWN, R.iv., Chief Surveyor of Ships, Marine Department.

Mr. Victor G. BOIVIN, Deputy Chief Surveyor of Ships, Marine Department.

\section{Norway}

Captain E. BR YN, Director of Shipping, Ministry of Industry, Trade and Shipping.

Mr. J. SCHÖNHEY DER, Engineer-in-Chief, Ministry of Industry, Trade and Shipping.

Commander O. I. LOENNECHEN, Commander, R.N.R.. and VicePresident in the Norwegian Shipowners' Association.

Captain Chr. MEYER, R.N. (Retd.), Former Director in the Norwegian Shipowners' Association. 
Mr. M. A. MASTER, Directeur Général de la Scindia Steam Navigation Company, Bombay.

Mr. R. S. MANI, Haut-Commissaire adjoint pour l'inde dans le Royaume-Uni.

Le Capitaine S. A. T. BULLOCK. Conseiller nautique du Gouvernement de l'Inde.

Le Capitaine de Corvette T. B. BOSE, R.I.N.. Ingénieur principal et Inspecteur de navire. Département de la Marine Marchande. Calcutta.

Le Gouvernement de l'Irlande:

Mr. Denis DEVLIN, Premier Conseiller, Bureau du Haut-Commissaire de l'Irlande.

Miss Thekla J. BEERE, chef de service. Ministère de l'Industrie et du Commerce.

Le Gouvernement de la République italienne:

Lieutenant général des Capitaineries de Port Giulio INGIANNI. Ancien Directeur général de la Marine Marchande et Président du Conuité italien pour la Sécurité de la Navigation.

Le Gouvernement des Pays-Bas:

M. P. S. van't HAAFF, inspecteur-général de la navigation.

M. A. J. W. van ANROOY, inspecteur de la radiotélégraphie côtière et navale.

Le Capitaine G. J. BARENDSE, ancien capitaine de la société anonyme de navigation, dite Holland-Amerika Lijn.

Le Capitaine J. F. van MUIJLWIJK, thésaurier de l'Union des capitaines et officiers de la Marine Marchande.

M. E. SMIT FZN, ingénieur, conseiller de construction navale auprès de l'Inspection de la navigation.

M. D. HUDIG, armateur, ancien directeur de la Société anonyme Koninklijke Nederlandsche Stoomboot Maatschappij.

M. T. M. PELLINKHOF, docteur en droit, fonctionnaire du Directorat Général de la Navigation.

Le Gouvernement de la Nouvelle-Zélande:

Le Capitaine de Corvette mécanicien Edward BROWN. Chef de la Surveillance des Navires, Ministère de la Marine.

Mr. Victor G. BOIVIN. Sous-chef de la Surveillance des Navires, Ministère de la Marine.

Le Gouvernement de la Norvège:

Le Capitaine E. BRYN, Directeur de la Navigation, Ministère de l'Industrie, du Commerce et de la Navigation.

Mr. J. SCHÖNHEYDER, Ingénieur en Chef, Ministère de l'Industrie, du Commerce et de la Navigation.

Le Capitaine de Frégate (cadre de réserve) O. I. LOENNECHEN, Marine Royale Norvégienne et vice-président de l'Association des Armateurs de Norvège.

Le Capitaine de vaisseau. Chr. MEYER, R.N.. en retraite. Ancien Directeur de l'Association des Armateurs de Norvège. 
Captain E. TONNESEN, Captain, Merchant Marine, and Chairman in the Norwegian Shipmasters' Association.

Mr. Johs. E. JOHANSEN, Secretary-General of the Norwegian Shipengineers' Union.

Mr. E. H. OTTERSEN, Radio Operator, Secretary in the Norwegian Seamen's Union.

\section{Pakistun}

Mr. H. I. R AHIMTOOLA, High Commissioner for Pakistan in London.

The Republic of Panama

Señor Eusebio A. MORALES, Counsellor at the Panamanian Legation in London.

The Republio of the Philippines

The Hon. Ramón J. FERNANDEZ, Minister designate.

The Republic of Poland

Captain H. BORAKOWSKI, Technical Shipping Adviser, Ministry of Shipping. Warszawa.

Captain Czeslaw ANTKOWIAK, Director of London Branch Office, Gdynia-America Lines Limited.

The Pormuguese Republic

Senhor João de Deus RAMOS, Counsellor to Embassy in London.

Commander José C. da ROCHA, Naval Altachc, Portuguese Embassy in London.

Constructor Commander Raul Alberto Soares da COSTA, Portuguese Navy. Division of Merchant Marine, Lisbon.

Lieut.-Commander Alfredo de Oliveira BAPTISTA. Portuguese Navy Division of Communications, Lisbon.

Captain Luiz Armando de LOURA, Portuguese Merchant Marine.

Sweden

Mr. Karl Hjalmar SıÖHOLM, Chief of Division to the Board of Trade.

\section{The Union of South Africa}

Mr. Reginald Gough PALMER, Senior Clerk of Department of Customs and Excise.

Captain G. A. CHETTLE, Examiner of Masters and Mates: Surveyor of Ships: Department of Customs and Excise. 
Le Capitaine E. TONNESEN, Marine marchande, et Président de l'Association Norvégienne des Capitaines de la Marine Marchande.

Mr. Jobs. E. JOHANSEN. Secrétaire général de l'Union norvécienne des Mécaniciens de Marine.

Mr. E. H. OTTERSEN. Opérateur de Radiotélégraphie, Secrétaire de I'Union Norvégienne des Marins.

Le Gouvernement du Pakistan:

Mr. H. I. RAHIMTOOLA, Haut-Commissaire pour le Pakistan à Londres.

Le Gouvernement de la République du Panama:

Señor Eusebio A. MORALES, Conseiller à la Légation du Panama à Londres.

Le Gouvernement des Philippines:

L'Honorable Ramón J. FERNANDEZ. Ministre.

Le Guuvernement de la République de Pologne:

Le Capitaine H. BORAKOWSKI, Conseiller technique de la Navigation, Ministère de la Navigation. Warszawa.

Le Capitaine Czeslaw ANTKOWIAK, Directeur de l'Agence GuyniaAmerica Lines à Londres.

Le Gouvernement de la République du Portugal:

Senhor Joào de Deus RAMOS, Conseiller à l'Ambassade du Portugal à Londres.

Capitaine de Frégate José C. DA ROCHA, Attaché naval à l'Ambassade du Portugal à Londres.

Ingénieur principal de construction navale Raul Alberto Soares da COSTA, Marine Portugaise, Directeur de la Marine Marchande. Ministère de la Marine, Lisbonne.

Le Capitaine de corvette Alfredo de Oliveira BAPTISTA, Branche des communications au Ministère de la Marine.

Le Capitaine Luiz Armando de LOURA, Marise Marchande Portugaise.

Le Gouvernement de la Suède:

Mr. Karl Hjalmar SJŏHOLM, Chef de division au Ministère du Commerce.

Le Gouvernement de l'Union Sud-Africaine:

Mr. Reginald Gough PALMER, Chef de Bureau au Département des Douanes.

Le Capitaine G. A. CHETTLE, Examinateur pour les Capitaines et les seconds-Capitaines, Inspecteur des navires au Département des Douanes.

Le Gouvernement de l'Union des Républiques Soviétiques Socialistes: 
The Unired Kingdom of Great Britain and Northern Ireland

Rt. Hon. Sir John ANDERSON, Chairman of the Port of London Authority.

Sir Gilmour JENKINS, Permanent Secretary of the British Ministry of Transport.

Mr. N. A. GUTTERY, Under-Secretary, British Ministry of Transport.

The United States of America

Admiral Joseph F. FARLEY, Commandant of the United States Coast Guard.

Mr. Jesse E. SAUGSTAD, Chief of the Shipping Division. Department of State.

The Federative People's Repuhlic of Yugoslavia

Mr. Luke DANCEVIC. Director-Directorate of Shipping. Split.

Who, having communicated their full powers, found in good and due form, have agreed as follows:-

\section{Article I}

(a) The Contracting Governments undertake to give effect to the provisions of the present Convention and of the Regulations annexed thereto. which shall be deemed to constitute an integral part of the present Convention. Every reference to the present Convention implies at the same time a reference to these Regulations.

(b) The Contracting Governments undertake to promulgate all laws, decrees, orders and regulations and to take all other steps which may be necessary to give the present Convention full and complete effect, so as to ensure that, from the point of view of safety of life, a ship is fit for the service for which it is intended.

\section{Article II}

The ships to which the present Convention applies are ships registered in countries the Governments of which are Contracting Governments, and ships registered in territories to which the present Convention is extended under Article XIII.

\section{Article III}

\section{Laws. Regulations, Reports}

The Contracting Governments undertake to communicate to the Intergovernmental Maritime Consultative Organisation (hereinafter called the Organisation)-

(a) the text of laws, decrees, orders and regulations which shall have been promulgated on the various matters within the scope of the present Convention:

(b) all available official reports or official summaries of reports in so far as they show the results of the provisions of the present Convention, provided always that such reports or summaries are not of a confidential nature; and 
Le Gouvernement du Royaume.Umi:

Le Très Honorable Sir John ANDERSON, Président de l'Administration du Port de Londres.

Sir Gilmour JENKINS. Secrétaire Permanent du Ministère des Transports.

Mr. N. A. GUTTERY. Sous-Secrétaire. Ministère des Transports.

Le Gouvernement des Erats-Unis d'Amérique:

L'Amiral Joseph F. FARLEY, Commandant de la Coast Guard des Etats-Unis d'Amérique.

Mr. Jesse E. SAUGSTAD, Chef de la division de la Navigation, Département d'Etat.

Le Gouvernement de Yougoslavie:

M. Luke DANCEVIC, Directeur de la Navigation à Split.

qui, après avoir communiqué leurs pleins pouvoirs trouvés en bonne et due forme, sont convenus des dispositions suivantes:

\section{Article 1}

(a) Les Gouvernements Contractants s'engagent à donner effet aux dispositions de la présente Convention et des Règles y annexées, qui seront considérées comme partie intégrante de la présente Convention. Toute référence à la présente Convention implique en même ternps une référence à ces Règles.

(b) Les Gouvernements Contractants s'engagent à promulguer toutes lois. tous décrets, ordres, et règlements et à prendre toutes autres mesures nécessaires pour donner à la Convention son plein et entier effet, afin de garantir, que du point de vue de la sauvegarde de la vie humaine, un navire est apte au service auquel il est destiné.

\section{Article II}

Les navires auxquels s'applique la présente Convention sont les navires immatriculés dans les Pays dont le Gouvemement est un Gouvernement Contractant, et les navires immatriculés dans les territoires auxquels la présente Convention est étendue en vertu de l'Article X'llI.

\section{Article III}

\section{Lois, Règlements, Rapporis}

Les Gouvernements Contractants s'engagent à communiquer à l'Organisation Maritime Consultative Intergouvernementale (ci-après dénommée l'Organisation--

(a) le texte des lois, décrets, ordres et règlements qui auront été promulgués sur les différentes matières qui entrent dans le champ de la présente Convention;

(b) tous les rapports officiels, ou résumés officiels de rapports dont ils pourraient disposer, dans la mesure où ces documents feront apparaitre les résultats des dispositions de la présente Convention. et à la condition, bien entendu, que ces rapports ou résumés de rapports n'aient pas un caractère confidentiel: 
(c) a sufficient number of specimens of their Certificates issued under the provisions of the present Convention for circulation to the Contracting Governments for the information of their officers.

\section{Article IV}

\section{Cases of Force Majeure}

(a) No ship, which is not subject to the provisions of the present Convention at the time of its departure on any voyage, shall become subject to the provisions of the present Convention on account of any deviation from its intended voyage due to stress of weather or any other cause of force majeure.

(b) Persons who are on board a ship by reason of force majeure or in consequence of the obligation laid upon the master to carry shipwrecked or other persons shall not be taken into account for the purpose of ascertaining the application to a ship of any provisions of the present Convention.

\section{Article V}

\section{Carriage of Persons in Emergency}

(a) For the purpose of moving persons from any territory in order to avoid a threat to the security of their lives a Contracting Government may permit the carriage of a larger number of persons in its ships than is otherwise permissible under the present Convention.

(b) Such permission shall not deprive other Contracting Governments of any right of control under the present Convention over such ships which come within their ports.

(c) Nolice of any such permission, together with a statement of the circumstances, shall be sent to the Organisation by the Contracting Government granting such permission.

\section{Article VI}

\section{Suspension in Case of War}

(a) In case of war, Contracting Governments which consider that they are affected, whether as belligerents or as neutrals, may suspend the whole or any part of the Regulations annexed hereto. The suspending Government shall immediately give notice of such suspension to the Organisation.

(b) Such suspension shall not deprive other Contracting Governments of any right of control under the present Convention over the ships of the suspending Government when such ships are within their ports.

(c) The suspending Government may at any time terminate such suspension and shall immediately give notice of such termination to the Organisation.

(d) The Organisation shall notify all Contracting Governments of any suspension or termination of suspension under this Article. 
(c) un nombre suffisant de spécimens des Certificats délivrés par eux, conformément aux dispositions de la présente Convention, en vue de les faire tenir aux Gouvernements Contractants qui les porteront à la connaissance de leurs fonctionnaires.

\section{Article IV \\ Cas de Force Majeure}

(a) Un navire qui n'est pas soumis, au moment de son départ pour un voyage quelconque, aux prescriptions de la présente Convention ne doit pas être astreint à ces prescriptions en raison d'un déroutement quelconque au cours de son voyage projeté. si ce déroutement est provoqué par le mauvais temps ou par toute autre cause de force majeure.

(b) Les personnes qui se trouvent à bord d'un navire par raison de force majeure ou qui s'y trouvent par suite de l'obligation imposée au Capitaine de transporter soit des naufragés, soit d'autres personnes, ne doivent pas entrer en ligne de compte lorsqu'il s'agit de vérifer l'application aux navires d'une prescription quelconque de la présente Convention.

\section{Article V}

\section{Transport des Personnes en cas d'urgence}

(a) Pour assurer l'évacuation des personnes d'un territoire quelconque en vue de les soustraire à une menace à la sécurité de leur vie. un Gouvernement Contractant peut permettre le transport sur ses navires d'un nombre de personnes supérieur au nombre permis en d'autres circonstances par la présente Convention.

(b) Une autorisation de cette nature ne prive pas les autres Gouvernements Contractants du droit de contrôle. aux termes de la présente Convention. sur de tels navires lorsque ces navires se trouvent dans les ports des dits Gouvernements.

(c) Avis de toute autorisation de cette nature sera envoyé à l'Organisation par le Gouvernement qui l'a accordée en même temps qu'un rapport sur les circonstances de fait.

\section{Article VI}

\section{Suspension en Cas de Guerre}

(a) Dans le cas d'une guerre les Gouvernements Contractants qui se considèrent comme affectés par elle, soit comme belligérants. soit comme neutres peuvent suspendre la totalité ou une partie quelconque de l'application des Règles y annexées. Le Gouvernement qui use de cette faculté doit immédiatement en donner avis à l'Organisation.

(b) Une telle décision ne prive les autres Gouvernements Contractants d'aucun droit de contrôle leur appartenant aux termes de la présente Convention sur les navires du Gouvernement usant de cette faculté, quand ces navires se trouvent dans leurs ports.

(c) Le Gouvernement qui a suspendu l'application de la totalité ou d'une partie de ces règles peut à tout moment mettre fin à cette suspension et doit immédiatement donner avis de sa décision à l'Organisation.

(d) L'Organisation doit notifier à tous les Gouvernements Contractants toute suspension ou fin de suspension décidée par application du présent Article. 


\section{Article VII}

\section{Prior Treaties and Conventions}

(a) As between the Contracting Governments the present Convention replaces and abrogates the International Convention for the Safety of Life at Sea which was signed in London on the 31 st May, 1929.( $\left.{ }^{1}\right)$

(b) All other treaties, conventions and arrangements relating to safety of life at sea, or matters appertaining thereto, at present in force between Governments parties to the present Convention, shall continue to have full and complete effect during the terms thereof as regards:-

(i) ships to which the present Convention does not apply;

(ii) ships to which the present Convention applies, in respect of matters for which it has not expressly provided.

(c) To the extent, however, that such treaties, conventions or arrangements conflict with the provisions of the present Convention, the provisions of the present Convention shall prevail.

(d) All matters which are not expressly provided for in the present Convention remain subject to the legislation of the Contracting Governments.

\section{Article VIII}

\section{Special Rules Drawn up by Agreement}

When in accordance with the present Convention special rules are drawn up by agreement between all or some of the Contracting Governments, such rules shall be communicated to the Organisation for circulation to all Contracting Governments.

\section{Article IX}

\section{Amendments}

(a) (i) The present Convention may be amended by unanimous agreement between the Contracting Governments.

(ii) Upon the request of any Contracting Government a proposed amendment shall be communicated by the Organisation to all Contracting Governments for consideration and acceptance under this paragraph.

(b) (i) An amendment to the present Convention may be proposed to the Organisation at any time by any Contracting Government, and such proposal if adopted by a two-thirds majority of the Assembly of the Organisation (hereinafter called the Assembly), upon recommendation adopted by a twothirds majority of the Maritime Safety Committee of the Organisation (hereinafter called the Maritime Safety Committee), shall be communicated by the Organisation to all Contracting Governments for their acceptance.

(ii) Any such recommendation by the Maritime Safety Committee shall be communicated by the Organisation to all Contracting Governments for their consideration at least six months before it is considered by the Assembly.

(c) (i) A conference of Governments to consider amendments to the present Convention proposed by any Contracting Government shall at any time be convened by the Organisation upon the request of one-third of the Contracting Governments.

$$
\text { (1) "Treaty Series No. } 34 \text { (1932)," Cmd. } 4198 .
$$




\section{Article VII}

Traités et Conventions Amtérieurs

(a) La présente Convention remplace et annule entre les Gouvernements Contractants la Convention Internationale pour la Sauvegarde de la Vie Humaine en Mer signée à Londres le 31 Mai 1929.

(b) Tous les autres Traités, Conventions ou Accords qui concernent la Sauvegarde de la Vie Humaine en Mer ou les questions qui s'y rapportent et qui sont actuellement en vigueur entre les Gouvernements parties à la présente Convention. conservent leur plein et enticr effet pendant la durée qui leur est assignée en ce qui concerne:

(i) les navires auxquels la présente Convention ne s’applique pas:

(ii) les navires auxquels la présente Convention s'applique en ce qui concerne les points ne taisant pas l'objet de prescriptions expresses dans la présente Convention:

(c) Au cas où, cependant, de tels Traités, Conventions ou Accords seraient en opposition avec les dispositions de la présente Convention, les dispositions de cette dernière doivent prévaloir.

(d) Tous les points qui ne font pas l'objet de prescriptions expresses dans la présente Convention restent soumis à la législation des Gouvernements Contractants.

\section{Article VIII}

Règles spéciales résullant d'Accords

Quand, en conformité avec la présente Convention, des règles spéciales sont établies par accords entre tous les Gouvernements Contractants, ou seulement quelques-uns d'entre eux, ces règles doivent être communiquées à l'Organisation pour être distribuées à tous les Gouvernements Contractants.

\section{Article IX}

Amendements

(a) (i) La présente Convention peut étre amendée par accord unanime entre les Gouvernements Contractants.

(ii) A la demande d'un Gouvernement Contractant quel qu'il soit, une proposition d'amendement doit être communiquée par l'Organisation à tous les Gouvernements Contractants, pour examen et acceptation au titre du présent paragrapbe.

(b) (i) Un amendement à la présente Convention peut, à tout moment, être proposé à l'Organisation par un Gouvernement Contractant. Si cette proposition est adoptée à la majorité des deux tiers par l'Assemblée de l'Organisation (ci-après dénommée l'Assemblée), sur une recommandation adoptée à la majorité des deux tiers par le Comité de la Sécurité Maritime de l'Organisation (ci-après dénommé le Comité de la Sécurité Maritime). elle doit être communiquée par l'Organisation à tous les Gouvernements Contractants en vue d'obtenir leur acceptation.

(ii) Toute recommandation de cette nature faite par le Comité de la Sécurité Maritime doit être communiquée par l'Organisation à tous les Gouvernements Contractants pour examen au moins six mois avant qu'elle ne soit examinée par l'Assemblée.

(c) (i) Une Conférence des Gouvernements, pour l'examen des amendements à la présente Convention proposés par l'un quelconque des Gouvernements Contractants, doit être convoquée à n'importe quel moment par l'Organisation à la demande d'un tiers des Gouvernements Contractants. 
(ii) Every amendment adopted by such conference by a two-thirds majority of the Contracting Governments shall be communicated by the Organisation to all Contracting Governments for their acceptance.

(d) Any amendment communicated to Contracting Governments for their acceptance under paragraph $(b)$ or $(c)$ of this Article shall come into force for all Contracting Governments, except those which before it comes into force make a declaration that they do not accept the amendment. twelve months after the date on which the amendment is accepted by two-thirds of the Contracting Governments including two-thirds of the Governments represented on the Maritime Safety Committee.

(e) The Assembly, by a two-thirds majority vote, including two-thirds of the Governments represented on the Maritime Safety Committee. and subject to the concurrence of two-thirds of the Contracting Governments to the present Convention, or a conference convened under paragraph $(c)$ of this Article by a two-thirds majority vote, may determine at the time of its adoption that the amendment is of such an important nature that any Contracting Government which makes a declaration under paragraph (d) of this Article and which does not accept the amendment within a period of twelve months after the amendment comes into force. shall. upon the expiry of this period, cease to be a party to the present Convention.

(f) Any amendment to the present Convention made under this Article which relates to the structure of a ship shall apply only to ships the keels of which are laid after the date on which the amendment comes into force.

(g) The Organisation shall inform all Contracting Governments of any amendments which come into force under this Article, together with the date on which such amendments shall come into force.

(h) Any acceptance or declaration under this Article shall be made by a notification in writing to the Organisation, which shall notify all Contracting Governments of the receipt of the acceptance or declaration.

\section{Article $\mathbf{X}$}

\section{Signature and Acceptance}

(a) The present Convention shall remain open for signature for one month from this day's date and shall. thereafter. remain open for acceptance. Governments of States may become parties to the Convention by :-

(i) signature without reservation as to acceptance:

(ii) signature subject to acceptance followed by acceptance; or

(iii) acceptance.

(b) Acceptance shall be effected by the deposit of an instrument with the Organisation, which shall inform all Governments that bave already accepted the Convention of each acceptance received and of the date of its receipt.

\section{Article XI}

\section{Coming into Force}

(a) The present Convention shall come into force on the Ist January, 1951, provided that. at least 12 montns before that date, not less than 15 acceptances, including 7 by countries each with not less than one million gross tons of shipping. have been deposited in accordance with Articles $\mathrm{X}$ and $\mathrm{XV}$. 
(ii) Tout amendement adopté à la majorité des deux tiers des Gouvernements Contractants par une telle Conférence doit être communiqué par l'Organisation à tous les Gouvernements Contractants en vue d'obtenir leur acceptation.

(d) Douze mois après la date de son acceptation par les deux tiers des Gouvernements Contractants-y compris les deux tiers des Gouvernements représentés au sein du Comité de la Sécurité Maritime-un amendement communiqué pour acceptation aux Gouvernements Contractants dans les conditions des paragraphes $(b)$ ou $(c)$ du présent Article. entre en vigueur pour tous les Gouvernements Contractants à l'exception de ceux qui, avant son entrée en vigueur, ont fait une déclaration aux termes de laquelle ils nacceptent pas le dit amendement.

(e) L'Assemblée, par un vote à la majorité des deux tiers comprenant les deux tiers des Gouvernements représentés au sein du Comité de la Sécurité Maritime. l'accord des deux tiers des Gouvernements parties à la présente Convention étant également obtenu, ou une Conférence convoquée, aux termes du paragraphe (c) du présent Article, par un vote à la majorité des deux tiers, peuvent spécifier au moment de l'adoption de l'amendement que celui-ci revêt une importance telle que tout Gouvernement Contractant, faisant une déclaration aux termes du paragraphe ( () du présent Article, et n'acceptant pas l'amendement dans un délai de douze mois à dater de son entrée en vigueur, cessera, à l'expiration du dit délai, d'être partie à la présente Convention.

(f) Un amendement à la présente Convention fait par application du présent Article et ayant trait à la structure des navires n'est applicable qu'aux navires dont la quille est posée après la date d'entrée en vigueur du dit amendement.

(g) L'Organisation doit informer tous les Gouvernements Contractants de tous amendements qui entrent en vigueur par application du présent Article, ainsi que de la date à laquelle ils prennent effet.

(h) Toute acceptation ou déclaration dans le cadre du présent Article doit être notifiée par écrit à l'Organisation qui notifiera à tous les Gouvernements la réception de cette acceptation ou déclaration.

\section{Article $\mathbf{X}$}

\section{Signature el acceptation}

(a) La présente Convention restera ouverte pour signature pendant un mois à compter de ce jour et restera ensuite ouverte pour acceptation. Les Gouvernements des Etats pourront devenir parties à la Convention par :

(i) la signature, sans réserve quant à l'acceptation;

(ii) la signature, sous réserve d'acceptation, suivie d'acceptation; ou

(iii) l'acceptation.

(b) L'acceptation s'effectue par le dépôt d'un instrument auprès de l'Organisation qui doit informer tous les Gouvernements ayant déjà accepté la Convention. de la réception de toute nouvelle acceptation et de la date de cette réception.

\section{Article XI}

\section{Entrée en vigueur}

(a) La présente Convention entrera en vigueur le $1^{\text {er }}$ Janvier 1951 à la condlition que, douze mois avant cette date, au moins quinze acceptations. dont celles de sept pays possédant chacun un tonnage global d'au moins un million de tonneaux de jauge brute, aient été déposées ell conformité avec les Articles X et XV. 
(b) Should 15 acceptances in accordance with paragraph (a) of this Article not have been deposited 12 months before the Ist January. 1951. the present Convention shall come into force 12 months after the date on which the last of such acceptances is deposited. The Organisation shall inform all Governments which have signed or accepted the present Convention of the date on which it comes into force. $\left({ }^{2}\right)$

(c) Acceptances deposited after the date on which the present Convention comes into force shall take effect three months after the date of their deposit.

\section{Article XII}

\section{Denunciarion}

(a) The present Convention may be denounced by any Contracting Government at any time after the expiry of five years from the date on which the Contention comes into force for that Government.

(b) Denunciation shall be effected by a notification in writing addressed to the Organisation which shall notify all the other Contracting Governments of any denunciation received and of the date of its receipt.

(c) A denunciation shall take effect one year, or such longer period as may be specified in the notification, after its receipt by the Organisation.

\section{Article Xill}

\section{Territorie's}

(a) (i) The United Nations in cases where they are the administering authority for a territory. or any Contracting Government responsible for the international relations of a territory, may at any time by notitication in writing given to the Organisation declare that the present Convention shall extend to such territory.

(ii) The present Convention shall from the date of the receipt of the notification or from such other date as may be specitied in the notification extend to the territory named therein.

(b) (i) The United Nations or any Contracting Government which has made a declaration under paragraph $(a)$ of this Article. at any time after the expiry of a period of five years from the date on which the Convention has been so extended to any territory, may by a notification in writing given to the Organisation declare that the present Convention shall cease to extend to any such territory named in the notification.

(ii) The present Convention shall cease to extend to any territory mentioned in such notification one year, or such longer period as may be specified therein, after the date of receipt of the notification by the Organisation.

(c) The Organisation shall inform all the Contracting Governments of the extension of the present Convention to any territories under paragraph $(a)$ of this Article, and of the termination of any such extension under the provisions of paragraph $(b)$. stating in each case the date from which the present Convention has been or will cease to be so extended. 
(b) Si 15 acceptations données par acceptation du paragraphe (a) du présent Article n'ont pas été déposées douze mois avant le ler Janvier 1951, la présente Convention entrera en vigueur douze mois après la date à laquelle la dernière de ces acceptations aura été déposée. L'Organisation devra informer tous les Gouvernements qui auront signé ou accepté la présente Convention de la date à laquelle elle entrera en vigueur.

(c) Les acceptations déposées postérieurement à la date à laquelle la présente Convention sera entrée en vigueur prendront effet trois mois après la date de leur dépôt.

\section{Article Xil}

\section{Dénonciation}

(a) La présente Convention peut être dénoncée par l'un quelconque des Gouvermements Contractants à tout moment après l'expiration d'une période de cinq ans, comptée à partir de la date à laquelle la Convention entre en vigueur pour ce Gouvernement.

(b) La dénonciation s'effectue par une notification écrite adressée a l'Organisation. Celle-ci notifiera à tous les autres Gouvernements Contractants toute dénonciation reçue et la date de sa réception.

(c) Une dénonciation prend effet un an après la date à laquelle la notification en aura été reçue par l'Organisation, ou à l'expiration de telle autre période plus longue spécifiée dans la notification.

\section{Article XIII}

\section{Territoires}

(a) (i) Les Nations Unies, lorsqu' clles sont responsables de l'Administration d'un territoire, ou tout Gouvernement Contractant qui a la responsabilité dassurer les relations internationales d'un territoire. peuvent à tout moment. par une notification écrite adressée à l'Organisation, déclarer que la présente Convention s'étend à un tel territoire.

(ii) L'application de la présente Convention sera étendue au territoire désigné dans la notification à partir de la date de réception de celle-ci, ou de telle autre date qui y serait indiquée.

(b) (i) Les Nations Unies, ou tout Gouvernement Contractant, qui ont fait une déclaration conformément au paragraphe $(a)$ du présent Article, peuvent à tout moment, après l'expiration d'une période de cinq ans à partir de la date à laquelle l'application de la Convention a été ainsi étendue à un territoire quelconque, déclarer par une notification écrite à l'Organisation que la présente Convention cessera de s'appliquer au dit territoire désigné dans la notification.

(ii) La Convention cessera de s'appliquer au Territoire désigné dans la notification au bout d'un an à partir de la date de réception de la notification par l'Organisation, ou de toute autre période plus longue qui serait fixée dans la notification.

(c) L'Organisation doit informer tous les Gouvernements Contractants de l'extension de la présente Convention à tout territoire dans le cadre du paragraphe (a) du présent Article et de la cessation de la dite extension conformément aux disposicions du paragraphe $(b)$, en spécifiant, dans chaque cas, la date à partir de laquelle la présente Convention est devenue ou a cessé d'être applicable. 


\section{Article XIV}

\section{Registration}

As soon as the present Convention comes into force it shall be registered by the Organisation with the Secretary-General of the United Nations.

\section{Article XV}

\section{Inerim Arrangements}

(a) Unless and until the Organisation, in accordance with the Convention on the Intergovernmental Maritime Consultative Organisation signed at Geneva on the 6th March, 1948, $\left({ }^{3}\right)$ takes over the duties assigned to it under the present Convention, the following provisions shall apply:-

(i) All duties which are assigned to the Organisation, other than those set forth in Article IX, shall be carried out by the Government of the United Kingdom of Great Britain and Northern Ireland (bereinafter called the Government of the United Kingdom).

(ii) Amendments to the present Convention may be proposed at any time by any Contracting Government to the Government of the United Kingdom and such proposals shall be communicated by the latter to the other Contracting Governments for their consideration and acceptance. If any such amendment is unanimously accepted by the Contracting Governments, the present Convention shall be amended accordinglv.

(iii) A Conference for the purpose of revising the present Convention shall be convened by the Government of the United Kingdom whenever, after the present Convention has been in force for five years, onethird of the Contracting Governments express a desire to that effect.

(iv) The present Convention shall be deposited in the archives of the Government of the United Kingdom, which shall transmit certified true copies thereof to all Signatory Governments.

(b) When the Organisation takes over the duties assigned to it under the present Convention, the Government of the United Kingdom will transmit to the Organisation any documents which have been deposited with or received by the Government of the United Kingdom under the present Convention. 


\section{Article XIV}

Enregistrement

Dès qu'elle entrera en vigueur, la présente Convention sera déposée pour znregistrement par l'Organisation auprès du Secrétaire Général des Nations Jnies.

\section{Article XV}

\section{Dispositions transitoires}

(a) Dans le cas où l'Organisation n'assumerait pas dans les conditions prévues par la Convention sur l'Organisation Maritime Consultative Intergouvernementale signée à Genève le 6 Mars 1948, les fonctions qui lui sont assignées par la présente Convention, ou en attendant qu'elle les assume, les dispositions suivantes seront appliquées:

(i) Toutes les fonctions qui sont assignées à l'Organisation, autres que celles prévues dans l'Article IX, seront assumées par le Gouvernement du Royaume-Uni de Grande-Bretagne et d'Irlande du Nord (ci-après dénommé le Gouvernement du Royaume-Uni).

(ii) Des amendements à la présente Convention peuvent être proposés à tout moment par l'un des Gouvernements Contractants au Gouvernement du Royaume-Uni. Ces propositions doivent être communiquées par ce dernier aux autres Gouvernements Contractants pour examen et acceptation. Si l'un quelconque de ces amendements est accepté unanimement par les Gouvernements Contractants. la présente Convention doit être amendée en conséquence.

(iii) Une Conférence ayant pour objet la révision de la présente Convention sera convoquée par le Gouvernement du Royaume-Uni lorsque, la présente Convention élant restée en vigueur pendant cinq ans. un tiers des Gouvernements Contractants en exprimera le désir.

(iv) La présente Convention sera déposée dans les archives du Gouvernement du Royaume-Uni qui en transmettra des copies certifiées conformes à tous les Gouvernements Signataires.

(b) Lorsque l'Organisation assumera les fonctions qui lui incombent aux termes de la présente Convention, le Gouvernement du Royaume-Uni transmettra à l'Organisation tous les documents qui auront été déposés ou reçus par le Gouvernement du Royaume-Uni aux tenmes de la présente Convention. 
In witness whereof the undersigned Plenipotentiaries have signed the present Convention.

Done in London this tenth day of June, 1948, in a single copy in English and French, each text being equally authoritative.

For the Argentine Republic:

A. J. ODDERA. JUAN EUGENIO PEFFABET.

J. MARTINEZ-VIVOT.

(Subject to acceptance.)

For the Commonwealth of Australia: Pour le Gouvernement du Commonwealth d'Australie:

NORMAN G. ROSKRUGE. SYDNEY POLLOCK.

(Subject to acceptance.)

For Belgium:

Pour le Gouvernement belge:

G. BERTRAND.

F. VAN GOOL.

(Subject to acceptance.)

For the Republic of the United Pour le Gouvernement des Etats-Unis States of Brazil:

GUSTAVO GOULART.

ANTONIO ALVES CAMARA.

PAULO NOGUEIRA PENIDO

J. C. REGO MONTEIRO.

(Subject to acceptance.)

For Canada:

J. LÉGER.

H. V. ANDERSON.

Pour le Gouvernement du Canada:

(Subject to acceptance.)

For the Republic of Chile:

Pour Ie Gouvernement du Chili:

K. OLSEN.

(Subject to acceptance.) 
For the Republic of China:

Pour le Gouvernement de la République de Chine:

T. H. CHENG.

(Subject to acceptance.)

For Denmark:

Pour le Gouvernement du Danemark:

OVE NIELSEN.

AAGE H. LARSEN.

A. POULSEN.

A. BACHE.

T. C. CHRISTENSEN.

TH. PETERSEN.

J. KASTRUP OLSEN.

HARRY EM RASMUSSEN.

(Subject to acceptance.)

For Egypt:

C. C. FANOUS.

Pour le Gouvernement de l'Égypte:

(Subject to acceptance.)

For the Republic of Finland:

Pour le Gouvernement de la République de Finlande:

WILLIAM SÖDERMAN.

(Subject to acceptance.)

For the French Republic:

Pour le Gouvernement de la République française:

G. ANDUZE-FARIS.

(Subject to acceptance.)

For Greece :

Pour le Gouvernement de la Grèce:

A. BACHAS.

(Subject to acceptance.)

For the Republic of Iceland:

Pour le Gouvernement d'Islande:

STEFAN THORVARDSSON.

(Subject to ratification.)

For India :

Pour le Gouvernement de l'Inde:

V. K. KRISHNA MENON.

W. A. MASTER.

T. B. BOSE.

S. A. T. BULLOCK.

(Subject to acceptance.) 
For Ireland:

Pour le Gouvernement de l'Irlande:

DENIS DEVLIN.

(Subject to acceptance.)

For the Italian Republic:

Pour le Gouvernement de la République italienne:

GIULIO INGIANNI.

(Subject to acceptance.)

For the Netherlands:

Pour le Gouvernement des Pays-Bas:

P. S. VAN'T HAAFF.

A. VAN ANROOY.

D. HUDIG.

E. SMIT FZN.

G. J. BARENDSE.

T. M. PELLINKHOF.

(Subject to acceptance.)

For New Zealand:

Pour le Gouvernement de NouvelleZélande :

EDWARD BROWN.

V. G. BOIVIN.

(Subject to acceptance.)

For Norway:

Pour le Gouvernesment de la Norvège:

E. BRYN.

J. SCHÖNHEYDER.

CHR. MEYER.

JOHS. E. JOHANSEN.

(Subject to acceptance.)

For Pakistan:

Pour le Gouvernement du Pakistan:

HABIB I. RAHIMTOOLA.

(Subject to acceptance.)

For the Republic of Panamá:

E. A. MORALES.

Pour le Gouvernesaent de la République du Panamá:

(Subject to acceptance.)

For the Republic of the Philippines: Pour le Gouvernement des Philippines:

R. J. FERNANDEZ.

(Subject to acceptance.) 
For the Republic of Poland:

H. BORAKOWSKI.

Pour le Gouvernement de la République de Pologne:

C. ANTKOWIAK.

(Subject to acceptance.)

For the Portuguese Republic:

Pour le Gouvernement de la République du Portugal:

JOAO DE DEUS RAMOS.

JOSE C. DA ROCHA.

RAUL ALBERTO SOARES DA COSTA

ALFREDO DE OLIVIERA BAPTISTA.

LUIZ ARMANDO DE LOURA.

(Subject to acceptance.)

For Sweden:

Pour le Gouvernement de la Suède:

HJALMAR SJÖHOLM.

(Subject to acceptance.)

For the Union of South Africa:

Pour le Gouvernement de l'Union Sud-Africaine:

R. GOUGH PALMER.

G. A. CHETTLE.

(Subject to acceptance.)

For the Union of Soviet Socialist Pour le Gouvernement de l'Union Republics :

des Républiques Soviétiques Socialistes:

For the United Kingdom of Great Pour le Gouvernement du Royaume. Britain and Northern Ireland: Uni:

JOHN ANDERSON.

GILMOUR JENKINS.

N. A. GUTTERY.

(Subject to acceptance.)

For the United States of America: Pour le Gouvernement des États-Unis d'Amérique:

JOSEPH F. FARLEY.

JESSE E. SAUGSTAD.

(Subject to acceptance.)

For the Federative People's Republic Pour le Gouvernement de Yougo of Yugoslavia: slavie: 


\section{REGULATIONS}

\section{CHAPTER I.-GENERAL PROVISIONS}

PART A.-APPLICATION, DEFINITIONS, \&c.

\section{Regulation I}

Application

(a) Unless expressly provided otherwise, the present Regulations apply only to ships engaged on international voyages.

(b) The classes of ships to which each Chapter applies are more precisely defined, and the extent of the application is shown, in each Chapter.

\section{Regnlation 2 \\ Definitions}

For the purpose of the present Regulations, unless expressly provided otherwise :-

(a) "Regulations" means the Regulations referred to in Article I $(a)$ of the present Convention.

(b) "Administration" means the Government of the country in which the ship is registered.

(c) "Approved" means approved by an Administration.

(d) "International voyage" means a voyage from a country to which the present Convention applies to a port outside such country, or conversely; and for this purpose every territory for the international relations of which a Contracting Government is responsible or for which the United Nations are the administering authority is regarded as a separate country.

(e) A passenger is every person other than:-

(i) the master and the members of the crew or other persons employed or engaged in any capacity on board a ship on the business of that ship; and

(ii) a child under one year of age.

(f) A passenger ship is a ship which carries more than 12 passengers.

(g) A cargo ship is any ship which is not a passenger ship.

(h) A tanker is a cargo ship constructed or adapted for the carriage in bulk of liquid cargoes of an inflammable nature.

(i) "New ship" means a ship the keel of which is laid on or after the date of coming into force of the present Convention.

(1) "Existing ship" means a ship which is not a new ship.

(k) A mile is 6.080 feet or 1.852 metres.

\section{Regulation 3}

\section{Exceptions}

(a) The present Regulations, unless expressly provided otherwise, do not apply to:-

(i) Ships of war and troopships.

(ii) Cargo ships of less than 500 tons gross tonnage.

(iii) Ships not propelled by mechanical means. 
REGLES

CHAPITRE I.-DISPOSITIONS GENERALES

PARTIE A-APPLICATION, DEFINITIONS, ETC.

\section{Règle 1}

Application

(a) Sauf disposition expresse contraire. le présent Règlement s'applique uniquement aux navires effectuant des voyages internationaux.

(b) Chacun des Chapitres définit avec plus de précision les catégories de navires auxquels il s'applique ainsi que le champ des dispositions qui leur sont applicables.

\section{Règle 2}

\section{Définitions}

Pour l'application des présentes Règles, sauf disposition expresse contraire :

(a) l'expression "Règles" désigne les Règles auxquelles se réfère l'Article I (a) de la présente Convention.

(b) l'expression "Administration" désigne le Gouvernement du pays où le navire est immatriculé.

(c) "Approuvée" signifie approuvé par une Administration.

(d) par "voyage international" il faut comprendre un voyage entre un pays auquel s'applique la présente Convention et un port situé en dehors de ce pays, ou réciproquement; et à cet égard tout territoire des relations internationales duquel un Gouvernement contractant est chargé ou qui est placé sous l'Administration de l'Organisation des Nations-Unies est considéré comme un pays distinct.

(e) un passager s'entend de toute personne autre que:

(i) le Capitaine et les membres de l'équipage ou autres personnes employées ou occupées en quelque qualité que ce soit à bord d'un navire pour les besoins de ce navire, et

(ii) les enfants de moins d'un an.

(f) un navire à passagers est un navire qui transporte plus de 12 passagers.

(g) un navire de charge est tout navire autre qu'un navire à passagers.

(h) l'expression " navire-citerne " désigne un navire de charge construit pour le transport en vrac de cargaisons liquides de nature inflammable, ou adapté à cet usage.

(i) l'expression "navire neuf" désigne un navire dont la quille a été posée le jour de l'entrée en vigueur de la présente Convention, ou postérieurement.

(j) l'expression " navire existant" désigne un navire qui n'est pas un navire neuf.

(k) un mille est égal à 1,852 mètres (ou 6,080 pieds).

\section{Règle 3}

\section{Exceptions}

(a) Sauf disposition expresse contraire, les présentes Règles ne s'appliquent pas:

(i) aux navires de guerre et aux transports de troupes,

(ii) aux navires de charge de moins de 500 tonneaux de jauge brute,

(iii) aux navires sans moyen de propulsion mécanique. 
(iv) Wooden ships of primitive build, such as dhows, junks, \&ec.

(v) Pleasure yachts not engaged in trade.

(vi) Fishing vessels.

(b) Notwithstanding any provisions of the present Regulations, nothing herein shall apply to ships solely navigating the Great Lakes of North America and their connecting and tributary waters as far east as the lower exit of the Lachinc Canal at Montreal in the Province of Quebec, Canada.

\section{Regulation 4}

\section{Exemprions}

(a) A ship which is not normally engaged on international voyages but which, in exceptional circumstances, is required to undertake a single international voyage may be exempted by the Administration from any of the requirements of the present Regulations provided that it complies with safety requirements which are adequate in the opinion of the Administration for the voyage which is to be undertaken by the ship.

(b) Each Administration shall submit to the Organisation as soon as possible after the lst of January each year a report showing the number of voyages of this nature for which cxemptions have been granted in the previous calendar year.

\section{Regulation 5}

\section{Equivalemis}

(a) Where in the present Regulations it is provided that a particular fitting. appliance or apparatus, or type thereof. shall be fitted or carried in a ship, or that any particular arrangement shall be adopted, an Administration may accept in substitution therefor any other fitting, appliance or apparatus, or type thereof, or any other arrangement, provided that the Administration shall have been satisfied by suitable trials that the fitting. appliance or apparatus. or type thereof. or the arrangement substituted is at least as effective as that specified in the present Regulations.

(b) Any Administration which so accepts, in substitution, a fitting. appliance or apparatus, or type thereof, or other arrangement, shall inform the Organisation. and, upon request. shall communicate to the Organisation particulars thereof together with a report on the trials made.

\section{PART B.-SURVEYS AND CERTIFICATES}

\section{Regulation 6 \\ Inspection and Survey}

The inspection and survey of ships, so far as regards the enforcement of the provisions of the present Regulations and the granting of exemptions therefrom, shall be carried out by officers of the country in which the ship is registered, provided that the Government of each country may entrust the 
(iv) aux navires en bois de construction primitive, tels que dhows. jonques. etc.

(v) aux yac:hts de plaisance ne se livrant à aucun trafic commercial,

(vi) aux navires de péche.

(b) Nonobstant toutes dispositions des présentes Règles, aucune de leurs stipulations ne doit s'appliquer aux navires circulant uniquement sur les Grands Lacs de l'Amérique du Nord, et sur les eaux qui les relient entre eux, ou en sont tributaires, limitées à l'Est, par le débouché du Canal Lachine à Montréal, dans la Province de Québec, Canada.

\section{Règle 4}

\section{Exemprions}

(a) Si par suite de circonstances exceptionnelles, un navire qui normalement n'eflectue pas de voyages internationaux, est amené à entreprendre un voyage international isolé, il peut être exempté par l'Administration d'une quelconque des dispositions des présentes Régles, à condition qu'il se conforme aux dispositions qui, de l'avis de l'Administration, sont suffisantes pour en assurer la sécurite au cours du voyage qu'il entreprend.

(b) Toute Administration doit soumettre à l'Organisation, à la date la plus rapprochée possible du $1^{\text {er }}$ janvier de chaque année, un rapport indiquant le nombre de voyages de cette nature pour lesquels ont été accordées des exemptions au cours de l'année civile précédente.

\section{Règle 5}

\section{Equivalences}

(a) Lorsque, dans les présentes Règles, il est prévu que l'on doit placer ou avoir à bord une installation, un dispositif ou un appareil quelconque. ou un certain type d'installation, de dispositif ou d'appareil, ou encore lorsqu'il est prévu qu'une disposition particulière doit être adoptée, toute Administration peut accepter en substitution toute autre installation, dispositif ou appareil, ou tout type d'installation, de dispositif ou d'appareil, ou tout autre arrangement, à la condition que cette Administration estime. à la suite d'essais appropriés, que l'installation, le dispositif ou l'appareil, ou le type d'installation, de dispositif ou d'appareil, ou la disposition substituée. a une efficacité au moins égale à celle qui est spécifiée dans les présentes Règles.

(b) Toute Administration qui accepte dans ces conditions la substitution d'une installation, d'un dispositif ou d'un appareil nouveau. ou d'un nouveau type d'installation, de dispositif ou d'appareil, ou d'une nouvelle disposition, doit en donner connaissance à l'Organisation et, sur demande, lui en communiquer la description détaillée en même temps qu'un rapport sur les essais effectués.

\section{PARTIE B.-VISITES ET CERTIFICATS \\ Règle 6}

\section{Inspections et Visires}

L'inspection et la visite des navires, en ce qui concerne l'application des prescriptions des présentes Règles et l'octroi des exemptions pouvant être accordées, doivent être effectuées par des fonctionnaires du pays où le navire est immatriculé. Toutefois, le Gouvernement de chaque pays peut confier 
inspection and survev either to surveyors nominated for the purpose or to organisations recognised by it. In every case the Government concemed fully guarantees the completeness and efficiency of the inspection and survey.

\section{Regulation 7}

\section{Initial and Subsequent Survey's of Passenger Ships}

(a) A passenger ship shall be subjected to the surveys specified below:(i) A survey before the ship is put in service.

(ii) A periodical survey once every 12 months.

(iii) Additional surveys, as occasion arises.

(b) The surveys referred to above shall be carried out as follows:-

(i) The survey before the ship is put in service shall include a complete inspection of its structure, machinery and equipments, including the outside of the ship's bottom and the inside and outside of the boilers. This survey shall be such as to ensure that the arrangements, material, and scantlings of the structure, boilers and their appurtenances, main and auxiliary machinery, electrical installation. radio installation, life saving appliances, fire detecting and extinguishing appliances, and other equipments, fully comply with the requirements of the present Convention, and of the laws, decrees. orders and regulations promulgated as a result thereof by the Administration for ships of the service for which it is intended. The survey shall also be such as to ensure that the workmanship of all parts of the ship and its equipments is in all respects satisfactory.

(ii) The periodical survey shall include an inspection of the structure, boilers, machinery and equipments, including the outside of the ship's bottom. The survey shall be such as to ensure that the ship, as regards the structure, boilers and their appurtenances, main and auxiliary machinery, electrical installation, radio installation, life saving appliances, Gire detecting and extinguishing appliances, and other equipments, is in satisfactory condition and fit for the service for which it is intended, and that it complies with the requirements of the present Convention, and of the laws, decrees, orders and regulations promulgated as a result thereof by the Administration.

(iii) A survey either general or partial, according to the circumstances. shall he made every time an accident occurs or a defect is discovered which affects the safety of the ship or the efficiency or completeness of its life saving appliances or other equipments, or whenever any important repairs or renewals are made. The survey shall be such as to ensure that the necessary repairs or renewals have been effectively made, that the material and workmanship of such repairs or renewals are in all respects satisfactory, and that the ship complies in all respects with the provisions of the present Convention and of the laws, decrees, orders and regulations promulgated as a result thereof by the Administration. 
l'inspaction et la visite de ses navires, soit à des inspecteurs désignés à cet effet, soit à des organismes reconnus par lui. Dans tous les cas, le Gouvernement intéressé se porte garant de l'intėgrité et de l'efficacité de l'inspection et de la visite.

\section{Règle 7}

\section{Inspections intitales et subséquentes des Navires à Passagers}

(a) Tout navirc à passagers doit être soumis aux visites définies ci-dessous:

(i) Une visite effectuée avant la mise en service du navire.

(ii) Une visite périodique effectuée tous les 12 mois.

(iii) Des visites supplémentaires le cas écbéant.

(b) Les visites spécifées ci-dessus doivent être effectuées comme suit:

(i) La visite effectuée avant la mise en service du navire doit comprendre une inspection complete de sa structure, de ses machines, du matériel d'armement, y compris une visite à sec de la carène, ainsi qu'une visite intérieure et extérieure des chaudières. Cette visite doit être effectuée de façon à assurer que les dispositions genérales, les matériaux et les échantillons de la structure, des chaudières et de leurs auxiliaires, des machines principales et auxiliaires, des installations électriques, des appareils de radio, des engins de sauvetage, des dispositifs de détection et d'extinction d'incendie. et de toute autre partie de l'armement, soient intégralement conformes aux prescriptions de la présente Convention, ainsi qu'aux dispositions de toutes lois, décrets, ordres et règlements promulgués pour l'application de cette Convention, par l'Administration, pour les navires affectés au service auquel ce navire est destiné. La visite doit également être effectuée de façon à assurer que l'état de toutes les parties du navire et de son armement soit à tous égards satisfaisant.

(ii) La visite périodique doit comprendre une inspection de la structurc, des chaudières, des machines et de l'armement, y compris une visite à sec de la carène. Cette visite doit être eff ectuée de façon à garantir qu'en ce qui concerne la structure, les chaudières et leurs auxiliaires, les machiues principales et auxiliaires, les installations électriques, les appareils de radio, les engins de sauvetage, les dispositifs de détection et d'extinction d'incendie et autres parties de l'armement, le navire est dans un état satisfaisant et approprié au service auquel il est destiné et qu'il répond aux prescriptions de la présente Convention ainsi qu'aux dispositions de toutes lois, décrets, ordres et règlements promulgués par l'Administration pour l'application de la présente Convention.

(iii) Une visite générale, ou partielle, sclon le cas, doit être effectuée chaque fois que se produit un accident ou qu'il se révèle un défaut affectant la sécurité du navire ou l'efficacité ou l'intégrité des engins de sauvetage ou autres apparaux. ou chaque fois que le navire subit des réparations ou rénovations importantes. La visite doit être effectuée de façon à garantir que les réparations ou rénovations nécessaires ont été réellement effectuées. que les matériaux employés pour ces réparations ou rénovations et leur exécution sont à tous points de vue satisfaisants et que le navire répond à tous égards aux prescriptions de la présente Convention ainsi qu'aux dispositions des lois, décrets, ordres. et règlements promulgués par l'Adminis. tration pour l'application de la prćsente Convention. 
(c) (i) The laws, decrees, orders and regulations referred to in paragraph (b) shall be in all respects such as to ensure that, from the point of view of safety of life, the ship is fit for the service for which it is intended.

(ii) They shall among other things prescribe the requirements to be observed as to the initial and subsequent hydraulic tests to which the main and auxiliary boilers, connections, steam pipes, high pressure receivers, and fuel tanks for internal combustion engines are to be submitted. including the test pressure to be applied and the intervals between two consecutive tests.

(d) The main and auxiliary boilers. connections, tanks and receivers, also steam-piping of more than 3 inches (or 76 millimetres) internal diameter shall be satisfactorily tested by hydraulic pressure when new. Steam pipes of more than 3 inches (or 76 millimetres) intcrnal diameter shall be tested by hydraulic pressure periodically.

\section{Regulation 8}

\section{Survey's of Life Saving Appliances and other Equipments of Cargo Ships}

The life saving and fire extinguishing appliances of cargo ships to which Chapters II and III of the present Regulations apply shall be subject to initial and subsequent surveys as provided for passenger ships in paragraph (a) of Regulation 7 with the substitution of 24 months for 12 months in subparagraph (a) (ii). and in paragraph (b) of that Regulation so far as it relates to life saving and fire extinguishing appliances. The lights and means of making sound signals and distress signals carried by the ship shall also be included in the surveys for the purpose of ensuring that they comply fully with the requirements of the present Convention and the International Collision Regulations.

\section{Regulation 9}

\section{Survey's of Radio Installations of Cargo Ships}

The radio installations of cargo ships to which Chapter $\mathrm{N}$ of the present Regulations applies shal] be subject to initial and subsequent surveys as provided for passenger ships in paragraph (a) of Regulation 7 and in paragraph (b) of that Regulation so far as it relates to radio installations.

\section{Regulation 10}

\section{Maintenance of Conditions after Survey}

After any survey of the ship under Regulation 7. 8 or 9 has been completed, no change shall be made in the structural arrangements, machinery. equipments. \&c.. covered by the survey. without the sanction of the Administration.

\section{Regulation 11}

\section{Issue of Cerrificates}

(a) (i) A certificate called a Safety Certificate shall be issued after inspection and survey to a passenger ship which complies in an efficient manner with the requirements of Chapters II. III, and IV and any other relevant requirements of the present Regulations. 
(c) (i) Les lois, décrets, ordres et règlements mentionnés au paragraphe (b) doivent être tels, à tous égards, qu'au point de vue de la sauvegarde de la vie humaine. le navire soit approprié au service auquel il est destiné.

(ii) Ces lois, décrets, ordres et réglements doivent, entre autres, fixer les prescriptions à observer en ce qui concerne les essais hydrauliques avant et après la mise en service, applicables aux chaudières principales et auxiliaires, aux connexions, aux tuyaux de vapeur, aux reservoirs à haute pression, aux réservoirs à combustible liquide pour moteurs à combustion interne, y compris les épreuves de pression et les intervalles entre deux épreuves consécutives.

(d) Les chaudières principales eı auxiliaires, les connections, les réservoirs et les caisses. ainsi que le tuyautage de vapeur de plus de 76 millimètres (ou 3 pouces) de diamètre intérieur doivent subir avec succès une épreuve hydraulique à l'état de neuf. Les tuyaux de vapeur de plus de 76 millimètres (ou 3 pouces) de diamètre intérieur doivent subir des épreuves hydrauliques périodiques.

\section{Règle 8}

Visites des Engins de Sauvetage et autres parlies de l'Armement des Navires de Charge

A bord des navires de charge, les engins de sauvetage et les dispositifs d'extinction d'incendie auxquels s'appliquent les Chapitres II et III des présentes Règles, doivent être soumis à une inspection avant et après la mise en service, semblable à celle prévue par les dispositions du paragraphe (a) de la Règle 7, pour les navires à passagers, sauf à remplacer 12 mois par 24 mois à l'alinéa (ii) du paragraphe $(a)$, et au paragraphe $(b)$. de la Règle dans la mesure où elle se rapporte aux engins de sauvetage ct aux dispositifs d'extinction d'incendie. Les feux et les dispositifs portés par le navire pour l'émission de signaux sonores, et de signaux de détresse, doivent également être soumis à ces visites en vue de garantir qu'ils répondent absolument aux dispositions de la présente Convention et aux Règles Internationales pour la prévention des Abordages.

\section{Règle 9}

\section{Visites des Installations radiotélígraphiques des Navires de Charge}

A bord des navires de charge, les installations de radio auxquelles s'applique le Chapitre IV des présentes Règles doivent être soumises aux visites a vant et après la mise en service, prévues par les paragraphes $(a)$ et (b) de la Règle 7 pour les navires à passagers, dans la mesure où cette Règle vise les installations radiotélégraphiques.

\section{Règle 10 \\ Maintien des Conditions après Visite}

Après l'une quelconque des visites prévues aux Règles 7,8 ou 9. aucun changement ne doit etre apporté sauf autorisation de l'Administration aux dispositions de structure, aux machines, à l'armement, etc., faisant l'objet de la visite.

\section{Règle 11}

\section{Délivrance de Certificars}

(a) (i) Un certificat dit Certificat de Sécurité doit être délivré après inspection et visite à un navire à passagers qui satisfait d'une manière effective aux prescriptions des Chapitres II. III et IV, et à toutes autres prescriptions applicables des présentes Règles. 
(ii) A certificate called a Safety Equipment Certificate shall be issued after inspection to a cargo ship which complies in an efficient manner with the relevant requirements of Chapters $\Pi$ and $I I I$ and any other relevant requirements of the present Regulations.

(iii) A certilicate called a Safety Radiotelegraphy Certificate shall be issued after inspection to a cargo ship, fitted with a radiotelegraph installation, which complies in an efficient manner with the requirements of Chapter IV and any other relevant requirements of the present Regulations.

(iv) A certificate called a Sufety Radiotelephony Certificate shall be issued after inspection to a cargo ship, fitted with a radiotelephone installation, which complies in an efficient manner with the requirements of Chapter IV and any other relevant requirements of the present Regulations.

(v) A certificate called an Exemption Certificate shall be issued to every ship to which exemption is granted by a Contracting Government under, and in accordance with, any of the provisions of the present Regulations.

(vi) Safety Certificates, Safety Equipment Certificates, Safety Radiotelegraphy Certificates. Safety Radiotelephony Certificates and Exemption Certificates shall be issued either by the Government of the country in which the ship is registered or by any person or organisation duly authorised by that Government. In every case that Government assumes full responsibility for the certificate.

(b) Notwithstanding any other provision of the present Convention. any certificate issued under, and in accordance with. the provisions of the International Couvention for the Safety of Life at Sea, 1929. which is current when the present Convention comes into force in respect of the Administration by which the certificate is issued. shall remain valid until it expires under the terms of Article 52 of the Convention of 1929.

\section{Regulation 12}

\section{Issue of Cerificase by another Governmens}

A Contracting Government may, at the request of the Administration. cause a ship to be surveyed. and, if satisfied that the requirements of the present Regulations are complied with, issue certificates to the ship in accordance with the present Regulations. Any certificate so issued must contain a statement to the effect that it has been issued at the request of the Government of the country in which the ship is registered, and it shall have the same force and receive the same recognition as a certificate issued under Regulation 11.

\section{Regulation 13}

\section{Duration of Certificases}

(a) Certificates shall be issued for a period of not more than 12 months, except Safety Equipment Certificates which shall be issued for a period of not more than 24 months.

(b) If a ship at the time when its certificate expires is not in a port of the country in which it is registered, the certificate may be extended by a duly authorised officer of that country; but such extension shall be granted only for the purpose of allowing the ship to complete its return voyage to the country in which it is registered. and then only in cases where it appears proper and reasonable so to do. 
(ii) Un certificat dit Certificat de Sécurité de Matériel d'Armement doit être délivré, après inspection, au navire de charge qui satisfait d'une manière effective aux prescriptions applicables des Chapitres U et III, et à toutes autres prescriptions applicables des présentes Règles.

(iii) Un certificat dit CertiGcat de Sécurité Radiotélégraphique doit être délivré après inspection au navire de charge, muni d'une installation radiotélégraphique, qui satisfait d'une manière effective aux prescriptions du Chapitre IV et à toutes autres prescriptions applicables des présentes Règles.

(iv) Un certificat dit Certificat de Sécurité Radiotéléphonique doit être délivré, après inspection, au navire de charge, muni d'une installation radiotéléphonique, qui satisfait d'une mauière effective aux prescriptions du Chapitre IV et à toutes autres prescriptions applicables des présentes Règles.

(v) Un certificat dit Certiticat d'Exemption doit être délivré à tout navire auquel une exemption est accordée par un Gouvernement Contractant pour l'application et en conformité des prescriptions de l'une quelconque des présentes Règles.

(vi) Des Certificats de Sécurité, des Certificats de Sécurité Radio. télégraphique, des Certificats de Sécurité Radiotéléphonique, des Certificats de Sécurité de Matériel d'Armement, et des Certilicats d'Exemption doivent être délivrés soit par le Gouvernement du pays dans lequel le navire est inınatriculé. soit par toute personne ou organisme dûment autorisé par ce Gouvernement. Dans tous les cas, ce Gouvernement assume l'entière responsabilité du certificat.

(b) Nonobstant toute autre prescription de la présente Convention. tout certificat delivré par application et en conformité des prescriptions de la Convention Internationale pour la sauvegarde de la Vie humaine en mer. 1929. qui est valable lors de l'entrée en vigueur de la présente Convention pour l'Administration qui a délivré le certificat, restera valable jusqu'à la date de son expiration aux termes de l'Article 52 de ladite Convention de 1929.

\section{Règle 12}

\section{Délivrance d'un Cerfificat par un autre Gouvernement}

Un Gouvernement Contractant peut, à la requête de l'Administration, faire visiter un navire et, s'il estime que les exigences des présentes Règles sont satisfaites, peut délivrer à ce navire des certificats en conformité avec les présentes Règles. Tout certilicat ainsi délivré doit porter une déclaration établissant qu'il a été delivré à la requète du Gouvernenıent du pays où le navire est immatriculé. Ce Certificat a la nuême valeur que le certificat délivré conformément à la Règle 11, et doit être accepté de la même façon.

\section{Règle 13}

\section{Durée de Validité des Certificats}

(a) Aucun certificat ne doit être délivré pour une durée de plus de douze mois, à l'exception des Certilicats de Sécurité de Matériel d'Armement qui ne doivent pas être délivrés pour une durée de plus de 24 mois.

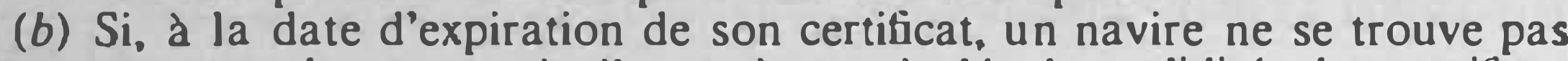
dans un port du pays où il est immatriculé, la validité du certificat peut être prorogée par un fonctionnaire dûment autorisé du pays où il est immatriculé; une telle prorogation ne doit, toutefois, être accordée que pour permettre au navire d'achever son voyage de retour au pays dans lequel il est immatriculé, et seulement dans le cas où cette mesure apparaîtra comme opportune et raisonnable. 
(c) No certificate shall be thus extended for a longer period than five months. and a ship to which such extension is granted shall not, on returning to the country in which it is registered. be entitled by virtue of such extension to leave that country again without liaving obtained a new certilicate.

(d) A certificate which has not been extended under the foregoing provisions of this Regulation may be extended by the Administration for a period of grace of up to one month from the date of expiry stated on it.

\section{Regulation 14 \\ Form of Cerrificates}

(a) All certiticates shall be drawn up in the official language or languages of the country by which they are issued.

(b) The form of the certificates shall be that of the models given in the Appendix to the present Regulations. The arrangement of the printed part of the model certificates shall be exactly reproduced in the certificates issued, or in certified copies thereof, and the particulars inserted in the certificates issued, or in certified copies thereof, shall be in Roman characters and Arabic figures.

\section{Regulation 15 \\ Posting up of Cerificates}

All certificates or certified copics thereof issued under the present Regulations, except Exemption Certificates or certified copies thereof, shall be posted up in a prominent and accessible place in the ship.

\section{Regulation 16}

\section{Acceptance of Cerlificales}

Certificates issued under the authority of a Contracting Government shall be accepted by the other Contracting Governments for all purposes covered by the present Convention. They shall be regarded by the other Contracting Governments as having the same force as the certilicates issued by them to their own ships.

\section{Regulation 17 \\ Qualificution of Cerrificares}

(a) If in the course of a particular voyage a ship bas on board a number of persons less than the total number stated in the Safety Certificate and is in consequence, in accordance with the provisions of the present Regulations, free to carry a smaller number of lifeboats and other life saving appliances than that stated in the certificate. a memorandum may be issued by the Government, officer, person, or organisation referred to in Regulation 11 and Regulation 13.

(b) This memorandum shall state that in the circumstances there is no infringement of the provisions of the present Regulations. It shall be annexed to the certificate and shall be substituted for it in so far as the life saving appliances are concerned. It shall be valid only for the particular voyage for which it is issued. 
(c) Aucun certificat ne doit être ainsi prorogé pour une période de plus de cinq mois, et un navire auquel cette prorogation aura été accordée ne sera pas en droit, en vertu de cette prorogation, à son retour dans le pays dans lequel il est immatriculé, de quitter à nouveau ce pays sans avoir obtenu un nouveau certificat.

(d) Un certificat qui n'a pas été prorogé conformément aux dispositions précédentes de la présente Règle peut être prorogé par l'Administration pour une période de grâce ne dépassant pas d'un mois la date d'expiration indiquée sur ce certificat.

\section{Règle 14}

\section{Type des Cerrificals}

(a) Tous les certificats doivent être rédigés dans la langue ou les langues officielles du pays par lequel ils sont délivrés.

(b) Le type des certificats doit être conforme aux modèles donnés à l'Annexe des présentes Règles. La disposition typographique des modèles de certificats doit être reproduite exactement dans les certificats délivrés, ou dans les copies certifiées conformes, et les indications portées sur les certificats délivrés, ou sur les copies certifiées conformes, doivent être écrites en caractères romains et en chiffres arabes.

\section{Règle 15 \\ Affichage des Cerrificais}

Tous les certificats, ou leur copie certifièc conforme, délivrés en vertu des présentes Règles, à l'exception des Certificats d'Exemption, ou de leur copie certifiée conforme, doivent être affichés sur le navire, à un endroit bien en vue et d’accès facile.

\section{Règle 16 \\ Acceptation des Cerrificuts}

Les certificats délivrés au nom d'un Gouvernement contractant doivent être acceptés par les autres Gouvernements contractants pour tout ce qui fait l'objet de la présente Convention. Ils doivent être considérés par les autres Gouvernements contractants comme ayant la même valeur que les certificats délivrés par ceux-ci à leurs propres navires.

\section{Règle 17}

\section{Avenant all Certificas}

(a) Si au cours d'un voyage particulier le nombre des personnes présentes à bord d'un navire est inférieur au nombre total indiqué sur le Certiticat de Sécurité et, si par suite ce navire a la faculté. conformément aux prescriptions des présentes Règles, d'avoir à bord un nombre d'embarcations de sauvetage et d'autres engins de sauvetage inférieur à celui qui est inscrit sur le certificat. un avenant peut être délivré par le Gouvernement. le fonctionnaire, la personne ou l'organisme mentionnés à la Règle 11 et à la Règle 13.

(b) Cet avenant doit mentionner que, dans les circonstances existantes. il n'est dérogé à aucune des dispositions des présentes Règles. 11 doit être annexé au Certificat et lui être substitué pour ce qui concerne les engins de sauvetage. Il n'est valable que pour le voyage particulier en vue duquel il est délivré. 


\section{Regulation 18}

\section{Control}

Every ship holding a certificate issued under Regulation 11 or Regulation 12 is subject in the ports of the other Contracting Governments to control by officers duly authorised by such Governments in so far as this control is dirccted towards verifying that there is on board a valid certificate and. if necessary, that the conditions of the ship's seaworthiness correspond substantially with the particulars of that certificate. Such certificate shall be accepted unless, in the opinion of the officer carrying out the control, the conditions of the ship's seaworthiness do not correspond substantially with the particulars of that certificate and the ship cannot proceed to sea without danger to the passengers or the crew. when he shall take such steps as will ensure that the ship shall not sail until it can proceed to sea without danger to the passengers or the crew. In the event of this control giving rise to intervention of any kind. the oflicer carrying out the control shall inform the Consul of the country in which the ship is registered in writing forthwith of all the circumstances in which intervention was deemed to be necessary, and the facts shall be reported to the Organisation.

\section{Regulation 19}

Privileges

The privileges of the present Convention may not be claimed in favour of any ship unless it holds appropriate valid certificates.

\section{PART C.-CASUALTIES}

\section{Regulation 20}

\section{Casualties}

(a) Each Administration undertakes to conduct an investigation of any major marine casualty occurring to any of its ships subject to the provisions of the present Convention. Such investigation, in addition to any other purpose, shall have the object of deternuning whether any changes in the present Regulations are desirable.

(b) Each Contracting Government undertakes to supply the Organisation with pertinent information concerning such casualties. No reports or recommendations of the Organisation based upon such information shall disclose the identity or nationality of the ships concerned or in any manner fix or imply responsibility upon any ship or person. 


\section{Règle 18}

\section{Contrôle}

Tout navire possédant un certificat délivré en vertu de la Règle 11 ou de la Zègle 12 est sujet, dans les ports des autres Gouvernements contractants, au contrôle de fonctionnaires dûment autorisés par ces Gouvernements, dans la limite où ce controle a pour objet de vérifier qu’il existe à bord un certificat valable, et, si nécessaire, de s'assurer que le navire est dans un état de navigabilité correspondant en substance aux indications de ce certificat. Ce certificat loit être accepté, à moins que, de l'avis du fonctionnaire qui effectue le conrôle, l'état de navigabilité du navire ne corresponde pas en substance aux ndications de ce certificat, et que le navire ne puisse prendre la mer sans langer pour les passagers et l'équipage. Dans ce cas il doit prendre les nesures nécessaires pour empêcher le navire d'appareiller jusqu'à ce qu'il puisse prendre la mer sans danger pour les passagers et l'équipage. Dans le zas où ce contrôle donnerait lieu à une intervention quelconque, le fonctionnaire exerçant ce contrôle doit informer immédiatement et par écrit le Consul Iu pays où le navire est immatriculé de toutes les circonstances qui ont fait zonsidérer cette intervention comme nécessaire, et il sera fait rapport des faits \& l'Organisation.

\section{Règle 19 \\ Bénéfice de la Convention}

Le bénéfice de la présente Convention ne peut être revendiqué en faveur d'aucun navire, s'il ne possède pas les certificats voulus, non périmés.

\section{PARTIE C.-ACCIDENTS}

\section{Règle 20}

Accidents

(a) Chaque Administration s'engage à effectuer une enquête au sujet de tout accident important survenu en mer a un de ses navires tombant sous le coup de la présente Convention. Cette enquête doit avoir pour objet, entre autres, de déterminer s'il convient d'apporter des modifications aux Règles.

(b) Chaque Gouvernement contractant s'engage à transmettre à l'Organisation toutes informations pertinentes sur ces accidents. Aucun rapport ou recommandation de l'Organisation basé sur ces informations ne doit révéler l'identité ou la nationalité des navires en cause, ni en aucune manière imputer la responsabilité de cet accident à un navire ou à une personne, ou laisser présumer leur responsabilité. 


\title{
CHAPTER II.-CONSTRUCTION
}

\author{
PART A.-GENERAL
}

\section{Regulation 1}

\section{Applicusion}

(a) (i) Unless expressly provided otherwise, this Chapter applies to new ships.

(ii) In the case of existing passenger ships and cargo ships which do not already comply with the provisions of this Chapter relating to new ships, the arrangements on each ship shall be considered by the Administration. with a view to improvements being made to provide increased safety where practicable and reasonable.

(b) For the purpose of this Chapter :-

(i) A new passenger shif is a passenger ship the keel of which is laid on or after the date of coming into force of the present Convention, or a cargo ship which is converted to a passenger ship on or after that date, all other passenger ships being described as existing passenger ships.

(ii) A new cargo ship is a cargo ship the keel of which is laid on or after the date of coming into force of the present Convention.

(c) Each Administration may, if it considers that the sheltered nature and conditions of the voyage are such as to render the application of any specific requirements of this Chapter unreasonable or unnecessary, exempt from those requirements individual ships or classes of ships belonging to its country which, in the course of their voyage, do not proceed more than 20 miles from the nearest land.

(d) In the case of a passenger ship which is permitted under Regulation 22 of Chapter 111 to carry a number of persons on board in excess of the lifeboat capacity provided, it shall comply with the special standards of subdivision set out in Regulation $5(e)$, and the associated special provisions regarding permeability in Regulation $4(d)$, unless the Administration is satisfied that, having regard to the nature and conditions of :he voyage. compliance with the other provisions of the Regulations of this Chapter is sufficient.

(e) In the case of passenger ships which are employed in the carriage of large numbers of unberthed passengers in special trades, such. for example, as the pilgrim trade, the Administration. if satisfied that it is impracticable to enforce compliance with the requirements of this Chapter, may exempt such ships, when they belong to its country, from those requirements on the following conditions:-

(i) That the fullest provision which the circumstances of the trade will permit shall be made in the matter of construction.

(ii) That steps shall be taken to formulate general rules which shall be applicable to the particular circumstances of these trades. Such rules shall be formulated in concert with such other Contracting Governments, if any, as may be directly interested in the carriage of such passengers in such trades. 


\title{
CHAPITRE 11.-CONSTRUCTION
}

\author{
PARTIE A.-GÉNÉRALITÉS
}

\section{Règle 1}

\section{Applicalion}

(a) (i) Le présent Chapitre s’applique aux navires neufs sauf dans les zas où il en est expressément disposé autrement.

(ii) Dans le cas de navires à passagers et de navires de charge existants ae satisfaisant pas déjà aux dispositions du présent Chapitre relatives aux navires neufs, les mesures à prendre pour chaque navire seront déterminées par l'Administration du pays auquel il appartient, de manière à accroître la sécurité sur les points où cela sera pratiquement rćalisable et raisonnable.

(b) Pour l'application de ce Chapitre:

(i) Un navire à passagers neuf est, soit un navire à passagers dont la quille a été posée à la date d'entrée en vigueur de la présente Convention. ou postérieurement, soit un navire de charge qui est transformé pour être affecté à un service de passagers à cette date ou postérieurement. Tous les autres navires à passagers sont considérés comme navires à passagers existants.

(ii) Un navire de charge neuf est un navire de charge dont la quille a été posée à la date d'entrée en vigueur de la présente Convention ou postérieurement à cette date.

(c) L'Administration, si elle considère que le parcours et les conditions de voyage sont tels que l'application d'une prescription quelconque du présent Chapitre n'est ni raisonnable, ni nécessaire. peut exempter de cette prescription des navires déterminés ou des catégories de navires, appartenant à son pays, qui, au cours de leur voyage. ne s’éloignent pas de plus de 20 milles de la terre la plus proche.

(d) Si un navire à passagers est autorisé, en vertu du Chapitre III, Règle 22. à transporter un nombre de personnes supérieur à celui que peuvent recevoir ses embarcations de sauvetage. il doit se conformer aux règles spéciales de cloisonnement faisant l'objet de la Règle $5(e)$, et aux dispositions spéciales connexes relatives à la perméabilité faisant l'objet de la Règle 4 (d). à moins que, compte tenu de la nature et des conditions du voyage. l'Aúministration considère comme suffisante l'application des autres dispositions des Règles du présent Chapitre.

(e) Dans le cas de navires à passagers qui sont utilisés à des transports spéciaux d'un grand nombre de passagers sans installation de couchettes, comme, par exemple, le transport de pèlerins, l'Administration peut, si elle juge qu'il est pratiquement impossible d'appliquer les prescriptions du présent Chapitre, exerupter ceux de ces navires qui appartiennent à son pays de l'application des prescriptions en question, sous les conditions suivantes:

(i) On doit appliquer, dans la plus large mesure compatible avec les circonstances du trafic. les prescriptions relatives à la construction.

(ii) Des mesures doivent être prises pour formuler des prescriptions générales qui devront s'appliquer au cas particulier de ce genre de trafic. Ces prescriptions doivent être formulées d'accord avec ceux des autres Gouvernements contractants, s'il y en a, qui pourraient être directement intéressés au transport de ces passagers. 
Notwithstanding any provisions of the present Convention, the Simla Rules, 1931. shall continue in force as between the parties to those Rules until the rules formulated under sub-paragraph (e) (ii) of this Regulation shall come into force.

\section{Regulation 2}

\section{Definitions}

For the purpose of this Chapter, unless expressly provided otherwise-

(a) (i) The subdivision loadline is the waterline used in determining the subdivision of the ship.

(ii) The deepest subdivision loadline is the waterline which corresponds to the greatest draught.

(b) The length of the ship is the length measured between perpendiculars taken at the extremities of the deepest subdivision loadline.

(c) The breadth of the ship is the extreme width from outside of frame to outside of frame at or below the deepest subdivision loadline.

(d) The bulkhead deck is the uppermost deck up to which the transverse watertight bulkheads are carried.

(e) The margin line is a line drawn at least 3 inches (or 76 millimetres) below the upper surface of the bulkhead deck at side.

(f) The draught is the vertical distance from the moulded base line amidships to the subdivision loadline in question.

(g) The permeability of a space is the percentage of that space which can be occupied by water.

The volume of a space which extends above the margin line shall be measured only to the height of that line.

(h) The machinery space is to be taken as extending from the moulded base line to the margin line and between the extreme main transverse watertight bulkheads bounding the spaces devoted to the main and auxiliary propelling machinery, hoilers when installed, and all permanent coal bunkers.

In the case of unusual arrangements, the Administration may define the limits of the machinery spaces.

(i) Passenger spaces are those which are provided for the accommodation and use of passengers, excluding baggage, store, provision and mail rooms.

For the purposes of Regulations 4 and 5 , spaces provided below the margin line for the accommodation and use of the crew shall be regarded as passenger spaces.

(j) In all cases volımnes shall be calculated to moulded lines.

\section{PART B.-SUBDIVISION AND STABILITY}

(Part B applies to passenger ships only except that Regulation 18 also applies to cargo ships)

\section{Regulation 3}

Floodable Length

(a) The floodable length at any point of the length of a ship shall be determined by a method of calculation which takes into consideration the form. draught and other characteristics of the ship in question. 
Jonobstant toute disposition contraire de la présente Convention, le Règle. nent de Simla de 1931 doit demeurer en viguseur entre les pays ayant souscrit - ce Règlement jusqu’à l'entrée en vigueur des prescriptions établies en iertu du paragraphe (e) (ii) de la Règle I des présentes Règles.

\section{Règle 2}

\section{Définitions}

Dans ce Chapitre, à moins qu'il n'en soit expressément disposé autrement :

(a) (i) La ligne de charge de compartimentage est la flottaison considérée lans la détermination du compartimentage du navire.

(ii) La ligne de charge maximum de compartimentage est la flottaison qui correspond au tirant d'eau le plus élevé.

(b) La longueur du navire est la longueur mesurée entre les pcrpendiculaires menées aux extrémités de la ligne de charge maximum de compartimentage.

(c) La largeur du navire est la largeur extrême hors membres mesurée à la ligne de charge maximum de compartimentage ou au-dessous de celte ligne de charge.

(d) Le pont de cloisonnement est le pont le plus élevé jusqu'auquel s'élèvent les cloisons étanches transversales.

(e) La ligne de surimmersion est une ligne tracée sur le bordé, à 76 millimètres (ou 3 pouces) au moins, au-dessous de la surface supérieure du pont de cloisonnement.

(f) Le tirant d'eau est la distance verticale du tracé de la quille hors membres au milieu, à la ligne de charge de compartimentage considérée.

(g) La perméabilité d'un espace s'exprime par le pourcentage du volume de cet espace que l'eau peut occuper.

Le volume d'un espace qui s'étend au-dessus de la ligne de surimmersion sera mesuré seulement jusqu'à la hauteur de cette ligne.

(h) La trunche des machines s'étend entre le tracé de la quille hors membres et la ligne de surimmersion, d'une part, et, d'autre part, entre les cloisons étanches transversales principales qui limitent l'espace occupé par les machines principales, les machines auxiliaires relatives à la propulsion, les chaudières, s'il y en a, et toutes les soutes à charbon permanentes.

Dans le cas de dispositions peu usuelles, l'Administration peut définir les limites des tranches des machines.

(i) Les espaces à passagers sont ceux qui sont prévus pour le logement et l'usage des passagers, à l'exclusion des soutes à bagage, des magasins, des soutes à provisions, à colis postaux et à dépêches.

Pour l'application des prescriptions des Règles 4 et 5 , les espaces prévus en dessous de la ligne de surimmersion pour le logement et l'usage de l'équipage, seront considérés comme espaces à passagers.

(j) Dans tous les cas, les volumes doivent être calculés hors membres.

\section{PARTIE B.--CLOISONNEMENT ET STABILITE}

(La Partie B s'applique seulement aux navires à passagers à l'exception de la Règle 18 qui s'applique également aux navires de charge)

\section{Règle 3}

\section{Longueur envahissable}

(a) Pour chaque point de la longueur du navire la longueur envahissable doit être déterminée par une méthode de calcul tenant compte des formes, du tirant d'eau et des autres caractéristiques du navire considéré. 
(b) In a ship with a continuous bulkhead deck, the floodable length at a given point is the maximum portion of the length of the ship, having its centre at the point in question, which can be flooded under the definite assumptions hereafter set forth in Regulation 4 without the ship being submerged beyond the margin line.

(c) (i) In the case of a ship not having a continuous bulkhead deck, the floodable length at any point may be determined to an assumed continuous margin line which at no point is less than 3 inches (or 76 millimetres) below the top of the deck (at side) to which the bulkbeads concerned and the shell are carried watertight.

(ii) Where a portion of an assumed margin line is appreciably below the deck to which bulkheads are carried, the Administration may permit a limited relaxation in the watertightness of those portions of the bulkheads which are above the margin line and immediately under the higher leck.

\section{Regulation 4}

\section{Permeability}

(a) The definite assumptions referred to in Regulation 3 relate to the permeabilities of the spaces below the margin line.

In detennining the floodable length. a uniform average permeability shall be used throughout the whole length of each of the following portions of the ship below the margin line :-

(i) the machinery space as defined in Regulation 2:

(ii) the portion forward of the machinery space; and

(iii) the portion abaft the machinery space.

(b) (i) For steamships the uniform average permeability throughout the machinery space shall be determined from the formula-

$$
80+12 \cdot 5\left(\frac{a-c}{v}\right) \text {. where }
$$

$\mathrm{a}=$ volume of the passenger spaces, as defined in Regulation 2, which are situated below the margin line within the limits of the machinery space.

$c=$ volume of between deck spaces below the margin line within the limits of the machinery space which are appropriated to cargo, coal or stores.

$v=$ whole volume of the machinery space below the margin line.

(ii) For ships propelled by internal combustion engines, the uniform average permeability shall be taken as 5 greater than that given by the above formula.

(iii) Where it is shown to the satisfaction of the Administration that the average permeability as determined by detailed calculation. is less than that given by the formula, the detailed calculated value may be used. For the purpose of such calculation, the permeabilities of passenger spaces, as defined in Regulation 2, shall be taken as 95, that of all cargo, coal and store spaces as 60. and that of double bottom, oil fuel and other tanks at such values as may be approved in each case by the Administration. 
(b) Pour un navire dont les cloisons transversales étanches sont limitées sar un pont de cloisonnement continu, la longueur envahissable en un point onné est la portion maximum de la longueur du navire, ayant pour centre e point considéré et qui peut être envahie par l'eau dans l'hypothèse des onditions définies par la Règle 4, sans que le navire s'immerge au-delà le la ligne de surimmersion.

(c) (i) Pour un navire n'ayant pas de pont de cloisonnement continu, la ongueur envabissable en chaque point peut être déterminée en considérant me ligne de surimmersion continue qui n'est en aucun point à moins de 36 millimètres (ou 3 pouces) au-dessous de la partie supérieure du pont (en zbord) jusqu'où les cloisonnements en question et le bordé extérieur sont naintenus étanches.

(ii) Si une partie de la ligne de surimmersion considéréc est sensiblement iu-dessous du pont jusqu'où les cloisonnements sont prolongés, l'Administraion peut autoriser des dérogations dans une certaine limite. pour l'étanchéité Jes parties du cloisonnement qui sont au-dessus de la ligne de surimmersion at immédiatement au-dessous du pont le plus élevé.

\section{Règle \&}

\section{Perméabilité}

(a) Les hypothèses visées à la Règle 3 sont relatives aux perméabilités des volumes limités à la partie haute par la ligne de surimmersion.

Dans la détermination des longueurs envahissables, on adopte une perméabilité moyenne uniforme pour l'ensemble de chacune des trois régions suivantes du navire, limitées à la partie haute par la ligne de surimmersion:

(i) la tranche des machines, comme définie par la Règle 2;

(ii) la partie du navire à l'avant de la tranche des machines;

(iii) la partie du navire à l'arrière de la tranche des machines.

(b) (i) Pour les navires à vapeur, la perruéabilité uniforme moyenne de la tranche des machines sera calculée par la formule:

dans laquelle

$$
80+12 \cdot 5\left(\frac{a-c}{v}\right)
$$

$a=$ volume des espaces à passagers, suivant la définition de la Règle 2 , qui sont situés au-dessous de la ligne de surimmersion et compris dans la tranche des machines;

$c=$ volume des entreponts affectés aux marchandises, au charbon ou aux provisions de bord, qui sont situés au-dessous de la ligne de surimmersion et compris dans la tranche des machines;

$v=$ volume total de la tranche des machines au-dessous de la ligne de surimmersion.

(ii) Pour les navires mus par moteurs à combustion interne, la perméabilité moyenne uniforme sera égale à la valeur donnée par la formule précédente augmentée de 5.

(iii) Lorsqu'on pourra établir, à la satisfaction de l'Administration, que la perméabilité moyenne déterminée par un calcul direct est moindre que celle qui résulte de la formule, on pourra substituer à cette dernière la perméabilité calculée directement. Pour ce calcul direct, la perméabilité des espaces affectés aux passagers, défnis par la Règle 2 sera prise égale à 95 , celle des espaces affectés aux marchandises, au charbon et aux provisions de bord, égale à 60 , et celle du double-fond, des soutes à combustible liquide et autres liquides sera fixée aux valeurs approuvées dans chaque cas par l'Administration. 
(c) Except as provided in paragraph (d) below, the uniform average permeability throughout the portion of the ship before (or abaft) the machinery space shall be determined from the formula-

$$
63+35 \frac{a}{v}
$$

where :-

$\mathrm{a}=$ volume of the passenger spaces, as defined in Regulation 2, which are situated below the margin line, before (or abaft) the machinery space, and

$v=$ whole volume of the portion of the ship below the margin line before (or abaft) the machinery space.

(d) In the case of a ship which is permitted under Regulation 22 of Chapter III to carry a number of persons on board in excess of the lifeboat capacity provided, and is required under paragraph (d) of Regulation 1 in this Chapter to comply with special provisions, the uniform average permeability throughout the portion of the ship before (or abaft) the machinery space shall be determined from the formula-

$$
95-35 \frac{b}{v}
$$

where:-

$\mathrm{b}=$ the volume of the spaces below the margin line and above the tops of floors, inner bottom, or peak tanks, as the case may be. which are appropriated to and used as cargo spaces, coal or oil fuel bunkers, store rooms. baggage and mail rooms, chain lockers and fresh water tanks, before (or abaft) the machinery space; and

$v=$ whole volume of the portion of the ship below the margin line before (or abaft) the machinery space.

In the case of ships engaged on services where the cargo holds are not generally occupied by any substantial quantities of cargo, no part of the cargo spaces is to be included in calculating "b."

(e) In the case of unusual arrangements the Administration may allow. or require, a detailed calculation of average permeability for the portions before or abaft the machinery spaces. For the purpose of such calculation the permeability of passenger spaces as defined in Regulation 2 shall be taken as 95 , that of spaces containing machinery as 80, that of all cargo, coal and store spaces as 60 , and that of double bottom, oil fuel and other tanks at such value as may be approved in each case by the Administration.

(f) If a between deck compartment between two watertight transverse bulkheads contains any passenger or crew space, the whole of that compartment. less any space completely enclosed within permanent steel bulkheads and appropriated to other purposes. shall be regarded as passenger space. If, however, the passenger or crew space in question is completely enclosed within permanent steel bulkheads, only the space so enclosed need be considered as passenger space. 
(c) Sauf dans les cas prévus au paragraphe (d) ci-après, la perméabilité noyenne uniforme sur toute la longueur du navire en avant (ou en arrière) de a tranche des machines, sera déterminée par la formule:

$$
63+35 \frac{a}{v}
$$

lans laquelle :

$a=$ volume des espaces à passagers, suivant la définition de la Règle 2. qui sont situés sous la ligne de surimmersion, en avant (ou en arrière) de la tranche des machines:

$v=$ volume total de la partie du navire au-dessous de la ligne de surimmersion et en avant (ou en arrière) de la tranche des machines.

(d) Dans le cas d'un navire autorisé, aux termes de la Règle 22 du Chapitre III, à transporter un nombre de personnes supérieur à la capacité de ses embarcations, et qui doit, aux termes du paragraphe (d) de la Règle 1 du présent Chapitre, satisfaire à des dispositions spéciales, la perméabilité uniforme moyenne dans toutes les parties du navire en avant (ou en arrière) de la tranche des machines doit être déterminée par la formule:

$$
95-35 \frac{b}{v}
$$

dans laquelle:

$\mathrm{b}=$ le volume des espaces situés en avant (ou en arrière) de la tranche des machines, au-dessous de la ligne de surimmersion et au-dessus de la partie supérieure des varangues, du double-fond ou des peaks, selon le cas, et propres à servir de cales à marchandises, de soutes à charbon ou à combustible liquide, de magasins à provisions de bord, de soutes à bagages, à dépêches et colis postaux, de puits aux chaînes et de citernes à eau douce :

$v=$ le volume total de la partie du navire située au-dessous de la ligne de surimmersion en avant (ou en arrière) de la tranche des machines.

Dans le cas de navires assurant des services au cours desquels les cales à marchandises ne sont généralement pas occupées par de fortes quantités de marchandises, il ne doit pas être tenu compte des espaces réservés aux marchandises dans le calcul de "b."

(e) Dans le cas de dispositions peu usuelles, l'Administration peut adnettre ou exiger le calcul direct de la perméabilité moyenne pour les parties situées à l'avant et à l'arrière de la tranche des machines. Afin de permettre ce calcul, la perméabilité des espaces à passagers. tels qu'ils sont définis au paragraphe (i) de la Règle 2, sera prise égale à 95, celle de la tranche des machines à 80 , celle de toutes les soutes à marchandises, à charbon et des magasins à 60 , et celle des doubles-fonds, des soutes à combustible et autres liquides, à un chiffre qui peut être dans chaque cas approuvé par l'Administration.

(f) $\mathrm{Si}$ un compartiment, dans un entrepont, entre deux cloisons étanches transversales, renferme un espace affecté aux passagers ou à l'équipage, on considérera comme espace à passagers l'ensemble de ce compartiment, en déduisant, toutefois, tout espace affecté à un autre service qui serait cornplètement entouré de cloisons métalliques permanentes. Si, cependant. l'espace en question affecté aux passagers ou à l'équipage est lui-même complètement entouré de cloisons métalliques permanentes, on ne comptera que cet espace comme espace à passagers.

43055 


\section{Regulation 5}

\section{Permissible Lengrh of Comparments}

(a) Ships shall be as efficiently subdivided as is possible baving regard to the nature of the service for which they are intended. The degree of subdivision shall vary with the length of the ship and with the service, in such manner that the highest degree of subdivision corresponds with the ships of greatest length, primarily engaged in the carriage of passengers.

(b) Factor of Subdivision.-The maximum permissible length of a compartment having its centre at any point in the ship's length is obtained from the tloodable length by multiplying the latter by an appropriate factor called the factor of subdivision.

The factor of subdivision shall depend on the length of the ship, and for a given length shall vary according to the nature of the service for which the ship is intended. It shall decrease in a regular and continuous manner-

(i) as the length of the ship increases, and

(ii) from a factor $A$, applicable to ships primarily engaged in the carriage of cargo. to a factor B. applicable to ships primarily engaged in the carriage of passengers.

The variations of the factors $A$ and $B$ shall be expressed by the following formulie (I) and (11) where L is the length of the ship as defined in Regulation 2:-

$L$ in feet

$$
\begin{aligned}
& A= \frac{190}{\mathrm{~L}-198}+\cdot 18(\mathrm{~L}=430 \text { and } \\
&\text { upwards }) \\
& \mathrm{L} \text { in metres } \\
& \mathrm{A}=\frac{58 \cdot 2}{\mathrm{~L}-60}+.18(\mathrm{~L}=131 \text { and } \\
&\text { upwards }) \\
& \mathrm{L} \mathrm{in} \mathrm{feet} \\
& \mathrm{B}=\frac{100}{\mathrm{~L}-138}+.18(\mathrm{~L}=260 \text { and } \\
&\text { upwards })
\end{aligned}
$$

$\mathrm{L}$ in metres

$$
\mathrm{B}=\frac{30 \cdot 3}{\mathrm{~L}-42}+\cdot 18(\mathrm{~L}=79 \text { and }
$$

(c) Critcrion of Service.-For a ship of given length the appropriate factor of subdivision shall be determined by the Critcrion of Service Numeral (hereinafter called the Criterion Numeral) as given by the following formula (III) and (IV) where:-

$\mathrm{C}_{\mathbf{8}}=$ the Criterion Numeral;

$\mathrm{L}=$ length of the ship. as defined in Regulation 2;

$M=$ the volume of the machinery space. as defined in Regulation 2: with the addition thereto of the volume of any permanent oil fuel bunkers which may be situated above the inner bottom and before or abaft the machinery space;

$P=$ The whole volume of the passenger spaces below the margin line, as defined in Regulation 2;

$\mathbf{V}=$ the whole volume of the ship below the margin line: 


\section{Règle 5}

\section{Longueur admissible des Compartiments}

(a) Lesnaviresdoivent être compartimentés aussi efficacement que possible eu égard à la nature du service auquel ils sont destinés. Le degré de compartimentage doit varier avec la longueur du navire et le service auquel le navire est destiné, de telle manière que le degré de compartimentage le plus élevé corresponde aux plus longs navires essentiellement affectés au transport des passagers.

(b) Facteur de cloisonnement.-La longueur maximum admissible pour le compartiment ayant son centre en un point quelconque de la longueur d'un navire, se déduit de la longueur envahissable, en multipliant celle-ci par un facteur approprié dit facteur de cloisonnement.

Le facteur de cloisonnement doit dépendre de la longueur du navire, et pour une longueur donnée. varic selon la nature du service pour lequel le navire est prévu. Ce facteur doit décroitre d'une façon régulière et continue :

(i) à mesure que la longueur du navire augmente, et

(ii) depuis un facteur $\mathrm{A}$ applicable aux navires essentiellement affectés au transport des marchandises. jusqu'à un facteur B applicable aux navires essentiellement affectés au transport des passagers.

Les variations des facteurs $A$ et $B$ sont dornées par les formules (I) et (II) suivantes, dans lesquelles $L$ est la longueur du navire définie par la Règle 2:

L en mètres

$$
\begin{aligned}
& A=\frac{58,2}{L-60}+0,18(L=131 \text { et au-dessus }) \\
& A=\frac{190}{L-198}+0,18(L=430 \text { et au-dessus }) \\
& B=\frac{L 0,3}{L-4}+0,18(L=79 \text { et au-dessus }) \\
& B=\frac{100}{L-138}+0,18(L=260 \text { et au-dessus })
\end{aligned}
$$

(c) Critérium de Service.-Pour un navire de longueur donnée, le facteur de cloisonnement approprié est déterminé à l'aide de la valeur du Critérium de Service (appelé ci-après Critérium), donné par les formules III et IV ci-après, dans lesquelles:

$\mathrm{C}_{\mathrm{s}}=$ le Critérium;

$\mathbf{L}=$ la longueur du navire, défnie par la Règle 2:

$M=$ le volume de la tranche des machines, détini par la Règle 2, mais en y ajoutant le volume de toutes les soutes permanentes à combustible liquide, situees hors du double-fond et en avant ou en arrière de la tranche des machines;

$P=$ le volume total des espaces à passagers au-dessous de la ligne de surimmersion d'après la définition de la Règle 2:

$V=$ le volume total du navire au-dessous de la ligne de surimmersion: 
$P_{1}=K N$ where:-

$\mathbf{N}=$ number of passengers for which the ship is to be certifed, and

$\mathrm{K}$ has the following values :-

Length in feet and volumes in cubic feet ... $.6 \mathrm{~L}$.

Length in metres and volumes in cubic metres $.056 \mathrm{~L}$.

Where the value of $\mathrm{KN}$ is greater than the sum of $\mathrm{P}$ and the whole volume of the actual passenger spaces above the margin line. the figure to be taken as $P_{1}$ is that sum or $\frac{z}{3}$, whichever is the greater.

When $P_{1}$ is greater than $P$ -

$$
C_{3}=72 \frac{M+2 P_{1}}{V+P_{1}-P}
$$

and in other cases-

$$
C_{3}=72 \frac{M+2 P}{V}
$$

For ships not having a continuous bulkhead deck the volumes are to be taken up to the actual margin lines used in determining the floodable lengths.

(d) Rules for Subdivision of Ships other than those covered by paragraph (e) of this Regulation.-(i) The subdivision abaft the forepeak of ships 430 feet (or 131 metres) in length and upwards baving a criterion numeral of 23 or less shall be governed by the factor $A$ given by formula (I); of those having a criterion numeral of 123 or more by the factor $\mathrm{B}$ given by formula (II); and of those having a criterion numeral between 23 and 123 by the factor $F$ obtained by linear interpolation between the factors $A$ and $B$, using the formula :-

$$
F=A-\frac{(A-B)(C,-23)}{100}
$$

Where the factor $F$ is less than $\cdot 40$ and it is shown to the satisfaction of the Administration to be impracticable to comply with the factor $F$ in a machinery compartment of the ship. the subdivision of such compartment may be governed by an increased factor, which, however, shall not exceed 40 .

(ii) The subdivision abaft the forepeak of ships less than 430 feet (or 131 metres) but not less than 260 feet (or 79 metres) in length baving a criterion numeral equal to S, where-

$$
S=\frac{9,382-20 L}{34}(L \text { in feet })=\frac{3,574-25 L}{13}(L \text { in metres })
$$

shall be governed by the factor unity; of those having a criterion numeral of 123 or more by the factor B given by the formula (II); of those having a criterion numeral between $S$ and 123 by the factor $F$ obtained by linear 
$\mathbf{P}_{1}=$ le produit $\mathrm{KN}$;

$\mathrm{N}=$ le nombre de passagers pour lequel le navire est destiné à être autorisé

$\mathrm{K}=0,056 \mathrm{~L}$, si $\mathrm{L}$ et $\mathrm{V}$ sont mesurés en mètres et mètres cubes respectivement $(0,6 \mathrm{~L}$, si $\mathrm{L}$ et $\mathrm{V}$ sont mesurés en pieds et pieds cubes respectivement).

Si la valeur du produit $\mathrm{KN}$ est plus grande que la valeur de la somme de $P$ et du volume total réel affecté aux passagers, au-dessus de la ligne de surimmersion, on peut prendre pour $P_{1}$ le plus grand des deux nombres correspondant à la somme mentionnée ci-dessus d'une part, et à la valeur de 2/3 de KN d'autre part.

Si $P_{1}$ est plus grand que $P$ on aura

$$
C_{s}=72 \frac{M+2 P_{i}}{V+P_{1}-P}
$$

et dans les autres cas

$$
C_{s}=72 \frac{M+2 P}{V}
$$

Dans le cas des navires n'ayant pas de pont de cloisonnement continu, on calculera les volumes jusqu'à la ligne de surimmersion effectivement considérée dans le calcul de la longueur envahissable.

(d) Prescriptions pour le Compartimentage des navires autres que ceux visés par le paragraphe (e) de la présente Règle.-(i) Le cloisonnement en arrière de la cloison d'abordage des navires ayant une longueur de 131 mètres (ou 430 pieds) et au-dessus et dont le critérium est au plus égal à 23. doit être déterminé par le facteur $A$ donné par la formule $I$; celui de ceux qui ont un critérium au moins égal à 123, par le facteur B donné par la formule II : enfin, celui de ceux qui ont un critérium compris entre 23 et 123, par un facteur $\mathrm{F}$ obtenu par interpolation linéaire, à l'aide de la formule:

$$
F=A-\frac{(A-B)\left(C_{s}-23\right)}{100}
$$

Si le facteur $F$ est inférieur à 0,40 et s'il est établi, à la satisfaction de l'Administrarion, qu'il est pratiquement impossible d'adopter ce facteur pour un compartiment de la tranche des machines du navire considéré, le cloisonnement de ce compartiment peut être déterminé avec un facteur plus élevé. pourvu, toutefois, que ce facteur ne soit pas supérieur à 0,40 .

(ii) Le cloisonnement en arrière de la cloison d'abordage des navires ayant moins de 131 mètres (ou 430 pieds), mais pas moins de 79 mètres (ou 260 pieds) de longueur, dont le critérium aura la valeur S donnée par la formule:

$$
S=\frac{3574-25 L}{13} \text { (L en mètres) }=\frac{9382-20 L}{34} \text { ( } L \text { en pieds) }
$$

doit être déterminé par un facteur égal à l'unité; celui de ceux dont le critérium est égal ou supérieur à 123, par le facteur B donné par la formule (II); entin. celui de ceux dont le critérium est compris entre $S$ et 123, par un facteur 
interpolation between unity and the factor B using the formula:-

$$
F=1-\frac{(1-B)\left(C_{5}-S\right)}{123-S}
$$

(iii) The subdivision abaft the forepeak of ships less than 430 feet (or 131 metres) but not less than 260 feet (or 79 metres) in length and having a criterion numeral less than S, and of all ships less than 260 feet (or 79 metres) in length shall be governed by the factor unity, unless, in either case, it is shown to the satisfaction of the Administration to be impracticable to comply with this factor in any part of the ship, in which case the Administration may allow such relaxation as may appear to be justified, having regard to all the circumstances.

(iv) The provisions of sub-paragraph (d) (iii) shall apply also to ships of whatever length, which are to be certified to carry a number of passengers exceeding 12 but not exceeding-

$$
{\frac{L^{2}}{7,000}}^{\text {(in feet) }}=\frac{L^{2} \text { (in metres) }}{650} \text { or } 50, \text { whichever is the less. }
$$

(e) Special Standards of Subdivision for Ships which are permitted under Regulation 22 of Chapter III to carry a number of persons on board in excess of the lifeboat capacity provided and are required under paragraph (d) of Regulation 1 in this Chapter 10 comply with special provisions.

(i) (a) In the case of ships primarily engaged in the carriage of passengers, the subdivision abaft the forepeak shall be governed by a factor of -50 or by the factor determined according to paragraphs $(c)$ and $(d)$ of this Regulation, if less than $\cdot 50$.

(b) In the case of such ships less than 300 feet (or 91.5 metres) in length, if the Administration is satisfied that compliance with such factor would be impracticable in a compartment. it may allow the length of that compartment to be governed by a higher factor provided the factor used is the lowest that is practicable and reasonable in the circumstances.

(ii) If, in the case of any ship whether less than 300 feet (or 91.5 metres) or not, the necessity of carrying appreciable quantities of cargo makes it impracticable to require the subdivision abaft the forepeak to be governed by a factor not exceeding 50 the standard of subdivision to be applied shall be determined in accordance with the following sub-paragraphs $(a)$ to $(e)$, subject to the condition that where the Administration is satisfied that insistence on strict compliance in any respect would be unreasonable. it may allow such alternative arrangement of the watertight bulkheads as appears to be justified on merits and will not diminish the general effectiveness of the subdivision.

(a) The provisions of paragraph (c) of this Regulation relating to the criterion numeral shall apply with the exception that in calculating the value of $P_{1}$ for berthed passengers $K$ is to have the value defined in paragraph $(c)$ of this Regulation or 125 cubic feet (or 3.55 cubic metres). whichever is the greater, and for unberthed passengers $\mathrm{K}$ is to have the value 125 cubic feet (or 3.55 cubic metres\}. 
sbtenu par interpolation linéaire entre l'unité et le facteur $\mathrm{B}$, au moyen de a formule:

$$
F=1-\frac{(1-B)\left(C_{9}-S\right)}{123-S}
$$

(iii) Le cloisonnement en arrière de la cloison d'abordage des navires iyant moins de 131 mètres (ou 430 pieds) de longueur, mais pas moins de 79 mètres (ou 260 pieds), dont le critérium est moindre que S, et de tous les navires ayant moins de 79 mètres (ou 260 pieds) de longueur, doit être déterminé par un facteur égal à l'unitci, à moins que, dans l'un ou l'autre cas il ne soit établi à la satisfaction de l'Administration qu'il est pratiquement impossible de maintenir ce facteur dans une partie quelconque du navire; dans ce cas, l'Administration pourra accorder des tolérances dans la mesure qui lui paraîtra justifiée par les circonstances.

(iv) Les prescriptions de l'alinéa (d) (iii) s'appliqueront également, quelle que soit leur longueur, aux navires qui seront prévus pour porter un nombre de passagers dépassant douze (12), mais ne dépassant pas le plus petit des deux nombres.

$$
\frac{L^{2}}{650}(L \text { en mètres })=\frac{L^{2}}{7,000}(L \text { en pieds) } \text { ou } 50
$$

(e) Règles spéciales de compartimentage des navires uutorisés, en verü de la Règle 22 du Chapitre III, d̀ transporter un nombre de personnes supérieur au nombre que peuvent recevoir leurs emburcations de sauvetage et tenus, aux termes du paragraphe (d) de la Règle I du présent Chapitre, de se conformer à des dispositions spéciales.

(i) (a) Dans le cas de navires essentiellement destinés au transport de passagers, le compartimentage en arrière de la cloison d'abordage doit être déterminé par le facteur 0.50 , ou par un facteur déterminé conformément aux paragraphes $(c)$ et $(d)$ de la présente Règle, s'il est inférieur à 0,50.

(b) $\mathrm{Si}$, dans le cas de navires de ce genre, d'une longueur inférieure à $91,5 \mathrm{~m}$. (ou 300 pieds), l'Administration reconnaît qu'il serait impossible d'appliquer un tel facteur à un compartiment, elle peut tolérer que la longueur de ce compartiment soit déterminée par un facteur supérieur, à condition que le facteur employé soit le plus faible qu'il est pratiquement possible et raisonnable d'adopter dans les circonstances envisagées.

(ii) $\mathrm{Si}$, dans le cas d'un navire quelconque, qu'il soit d'une longueur inférieure à $91,5 \mathrm{~m}$. (ou 300 pieds), ou non. la nécessité de transporter de fortes quantités de marchandises ne permet pas, en pratique, d'exiger que le cloisonnement en arrière de la cloison d'abordage soit déterminé par un facteur ne dépassant pas 0,50 . le degré de compartimentage applicable sera déterminé conformément aux alinéas $(a)$ à $(e)$ suivants, étant entendu, toutefois, que l'Administration pourra admettre, si elle estime peu raisonnable d'insîster pour une application stricte à quelque égard que ce soit, toute autre disposition de cloisons étanches se justifiant par ses qualités, et ne diminuant pas l'efficacité générale du compartimentage.

(a) Les dispositions du paragraphe (c) de la présente Règle, relatives au Critérium de Service, doivent s'appliquer; toutefois, pour le calcul de la valeur de $P_{1}$. K doit avoir, pour les passagers en couchettes, la plus grande des deux valeurs suivantes, soit la valeur déter. minee au paragraphe $(c)$ de la présente Règle, soit 3,55 mètres cubes (ou 125 pieds cubes), et, pour les passagers non pourvus de couchettes, une valeur de 3,55 metres cubes (ou 125 pieds cubes). 
(b) The factor $\mathrm{B}$ in paragraph (b) of this Regulation shall be replaced by the factor $\mathrm{BB}$ determined by the following formula:-

$\mathrm{L}$ in feet

$\mathrm{BB}=\frac{57.6}{\mathrm{~L}-108}+\cdot 20(\mathrm{~L}=180$ and upwards $)$

$\mathrm{L}$ in metres

$\mathrm{BB}=\frac{17.6}{\mathrm{~L}-33}+\cdot 20(\mathrm{~L}=55$ and upwards $)$

(c) The subdivision abaft the fore peak of ships 430 feet (or 131 metres) in length and upwards having a criterion numeral of 23 or less shall be governed by the factor $\mathbf{A}$ given by formula (I) in paragraph $(b)$ of this Regulation; of those having a criterion numeral of 123 or more by the factor BB given by the formula in sub. paragraph (ii) (b) of this paragraph: and of those having a criterion numeral between 23 and 123 by the factor $F$ obtained by linear interpolation between the factors $A$ and $B B$, using the formula:-

$$
F=A-\frac{(A-B B)\left(C_{s}-23\right)}{100}
$$

except that if the factor $F$ so obtained is less than 50 the factor to be used shall be either -50 or the factor calculated according to the provisions of paragraph (d) (i) of this Regulation, whichever is the smaller.

(d) The subdivision abaft the fore peak of ships less than 430 feet (or 131 metres) but not less than 180 feet (or 55 metres) in length having a criterion numeral equal to $S_{1}$ where-

$$
\begin{aligned}
& S_{1}=\frac{1,950-4 L}{10}(L \text { in feet }) \\
& S_{2}=\frac{3,712-25 L}{19}(L \text { in metres })
\end{aligned}
$$

shall be governed by the factor unity; of those having a criterion numeral of 123 or more by the factor BB given by the formula in sub-paragraph (ii) (b) of this paragraph: of those having a criterion numeral between $S_{1}$ and 123 by the factor $F$ obtained by linear interpolation between unity and the factor $B B$, using the formula:-

$$
F=1-\frac{(1-B B)\left(C_{s}-S_{1}\right)}{123-S_{1}}
$$

except that in either of the two latter cases if the factor so obtained is less than - 50 the subdivision may be governed by a factor not exceeding $\cdot 50$.

(e) The subdivision abaft the fore peak of ships less than 430 feet (or 131 metres) but not less than 180 feet (or 55 metres) in length and having a criterion numeral less than $S_{1}$, and of all ships less than 180 feet (or 55 metres) in length shall be governed by the factor unity, unless it is shown to the satisfaction of the Administra. tion to be impracticable to comply with this factor in particular compartments. in which event the Administration may allow such 
(b) Le facteur B au paragraphe (b) de la présente Règle doit être remplacé par le facteur BB, déterminé selon la formule suivante:

L en mètres

$$
\begin{aligned}
\mathrm{BB} & =\frac{17,6}{\mathrm{~L}-33}+0,20 \quad(\mathrm{~L}=55 \text { et au-dessus }) \\
& \mathrm{L} \text { en pieds } \\
\mathrm{BB} & =\frac{57,6}{\mathrm{~L}-108}+50,20 \quad(\mathrm{~L}=180 \text { et au-dessus })
\end{aligned}
$$

(c) Le cloisomement en arrière de la cloison d'abordage des navires ayant une longueur de 131 mètres (ou 430 pieds) et au-dessus. et dont le critérium est au plus égal à 23, doit être déterminé par le facteur A donné par la formule (I) figurant au paragraphe (b) de la présente Règle; celui de ceux qui ont un critérium au moins égal à 123 , par le facteur BB, donné par la formule figurant à l'alinéa (ii) (b) ci-dessus; enfin, celui de ceux qui ont un critérium compris entre 23 et 123. par un facteur $F$ obtenu par interpolation linéaire entre les facteurs $A$ et $B B$ à l'aide de la formule.

$$
F=A-\frac{(A-B B)\left(C_{8}-23\right)}{100}
$$

sous réserve que, si le facteur $\mathrm{F}$ ainsi obtenu est inférieur à 0,50. le facteur à employer sera le moindre des deux nombres, soit 0,50. soit un facteur calculé conformément aux dispositions du para. graphe (d) (i) de la présente Règle.

(d) Le cloisonnement en arrière de la cloison d'abordage des navires ayant moins de 131 mètres (ou 430 pieds) mais pas moins de 55 mètres (ou 180 pieds) de longueur, dont le critérium aura la valeur $S_{1}$ donnée par la formule:

$$
\begin{aligned}
& S_{8}=\frac{3712-25 L}{19} \text { (L en mètres) } \\
& S_{8}=\frac{1950-4 L}{10} \text { (L en pieds) }
\end{aligned}
$$

doit être déterminé par un facteur égal à l'unité; celui de ceux dont le critérium est égal ou supérieur à 123, par le facteur BB donné par la formule figurant à l'alinéa (ii) (b) du présent paragraphe, enfin celui de ceux dont le critérium est compris entre $S_{1}$ et 123 par le facteur $F$ obtenu par interpolation linéaire entre l'unité et le facteur BB, au moyen de la formule :

$$
F=1-\frac{(1-B B)\left(C_{s}-S_{s}\right)}{123-S_{1}}
$$

sous réserve que, si dans chacun des deux derniers cas, le facteur ainsi obtenu est inférieur à 0,5 , le cloisonnement puisse être déterminé par un facteur ne dépassant pas 0,50 .

(e) Le cloisonnement en arrière de la cloison d'abordage des navires ayant moins de 131 mètres (ou 430 pieds) de longueur, mais pas moins de 55 mètres (ou 180 pieds) de longueur, et dont le critérium est moindre que $S_{1}$, et celui de tous les navires ayant moins de 55 mères (ou 180 pieds) de longueur, doit être déterminé par un facteur égal à l'unité, à moins qu'il ne soit établi à la satisfaction de l'Administration qu'il est pratiquement impossible de maintenir ce facteur 
relaxations in respect of those compartments as appear to be justified, having regard to all the circumstances, provided that the aftermost compartment and as many as possible of the forward compartments (between the forepeak and the after end of the machinery space) shall be kept within the boodable length.

\section{Regulation 6}

\section{Special Rules concerning Subdivision}

(a) Where in a portion or portions of a ship the watertigbt bulkbeads are carried to a higher deck than in the remainder of the sbip. and it is desired to take advantage of this higher extension of the bulkheads in calculating the fondable length. separate margin lines may be used for each such portion of the ship provided that-

(i) the sides of the ship are extended througbout the ship's length to the deck corresponding to the upper margin line and all openings in the shell plating below this deck throughout the length of the ship are treated as being below a margin line. for the purposes of Regulation 13; and

(ii) the two compartments adjacent to the "step " in the bulkbead deck are each within the permissible length corresponding to their respective margin lines and. in addition, their combined lengtb does not exceed twice the permissible length based on the lower margin line.

(b) (i) A compartment may exceed the permissible length determined by the rules of Regulation 5 provided the combined length of each pair of adjacent compartments to which the compartment in question is common does not exceed either the floodable length or twice the permissible length, whichever is the less.

(ii) If one of the two adjacent compartments is situated inside the machinery space, and the second is situated outside the machinery space. and the average permeability of the portion of the sbip in which the second is situated differs from that of the machinery space, the combined length of the two compartments shall be adjusted to the mean average permeability of the two portions of the ship in which the compartments are situated.

(iii) Where the two adjacent compartments have different factors of subdivision, the combined length of the two compartments shall be determined proportionately.

(c) In ships 430 feet (or 131 metres) in length and upwards, one of the main tiansverse bulkheads abaft the fore peak shall be fitted at a distance from the forward perpendicular which is not greater than the permissible length.

(d) A main transverse bulkhead may be recessed provided that all parts of the recess lie inboard of vertical surfaces on both sides of the ship, situated at a distance from the shell plating equal to one-fifth the breadth of the ship, as defined in Regulation 2, and measured at right angles to the centre line at the level of the deepest subdivision loadline.

Any part of a recess which lies outside these limits shall be dealt with as a step in accordance with the following paragraph. 
dans des compartiments particuliers; dans ce cas, l'Administration pourra accorder des tolérances en ce qui concerne ces compartiments, dans la mesure qui lui paraîtra justifiée par les circonstances. à condition toutefois que le compartiment extrême arrière et le plus grand nombre possible des compartiments avant (compris entre la cloison d'abordage et l'extrémité arrière de la tranche des machines) n'aient pas une longueur dépassant la longueur admissible.

\section{Règle 6 \\ Prescriprions spéciales relasives «u Comparsimeniage}

(a) Quand, dans une olı plusieurs régions du navire, les cloisons étanches ont prolongées jusqu’à un pont plus élevé que sur le reste du navire et u'on désire bénéficier de cette extension des cloisons en hauteur. on peut. jour calculer la longueur envahissable, utiliser des lignes de surimmersion éparées, pour chacune de ces régions du navire, à condition:

(i) que la muraille du navire s'étende sur toute la longueur du navire jusqu'au pont correspondant à la ligne de surimmersion la plus haute et que toutes les ouvertures dans le bordé extérieur au-dessous de ce pont sur toute la longueur du navire soient considérées comme étant, au regard de la Règle 13, au-dessous de la ligne de surimmersion.

(ii) que les deux compartiments adjacents à la "baionnette" du pont de cloisonnement soient, chacun, dans les limites de la longeur admissible, correspondant à leurs lignes de surimmersion respectives, et qu'en outre, leurs longueurs combinées n'excèdent pas le double de la longueur admissible calculée avec la ligne de surimmersion inférieure.

(b) (i) La longueur d'un compartiment peut dépasser la longueur admissible fixée par les prescriptions de la Règle 5. pourvu que la longueur de chacune des deux paires de compartiments adjacents, comprenant chacune le compartiment en question, ne dépasse ni la longueur envahissable, ni deux fois la longueur admissible.

(ii) Si l'un des deux compartiments adjacents est situé dans la tranche des machines et le second en dehors de la tranche des machines, et si la perméabilité moyenne de la portion du navire où le second est situé n'est pas la même que celle de la tranche des machines, la longueur combinée des deux compartiments doit être fixée en prenant pour base la moyenne des perméabilités des deux portions du navire auquel les compartiments en question appartiennent.

(iii) Lorsque les deux compartiments adjacents ont des facteurs de cloisonnement différents, la longueur combinée de ces deux compartiments doit être déterminée proportionnellement.

(c) Pour les navires d'au moins 131 mètres (ou 430 pieds) de longueur, une des cloisons principales transversales en arrière de la cloison d'abordage doit être placée à une distance de la perpendiculaire avant au plus égale à la longueur admissible.

(d) Une cloison transversale principale peut présenter une niche, pourvu qu'aucun point de la niche ne dépasse. vers l'extérieur du navire, deux surfaces verticales menées de chaque bord à une distance du bordé égale à $1 / 5^{\text {smo }}$ de la largeur du navire définie par la Règle 2, cette distance étant mesurée normalement au plan diamétral du navire et dans le plan de la ligne de charge maximum de compartimentage.

Si une partie d'une niche dépasse les limites ainsi fixées, cette partie sera considérée comme une baionnette et on lui appliquera les règles du paragraphe suivant. 
(e) A main transverse bulkhead may be stepped provided that it meets one of the following conditions:-

(i) The combined length of the two compartments, separated by the bulkhead in question, does not exceed either 90 per cent. of the floodable length or twice the permissible length, except that in ships having a factor of subdivision greater than 9 , the combined length of the two compartments in question shall not exceed the permissible length.

(ii) Additional subdivision is provided in way of the step to maintain the same measure of safety as that secured by a plane bulkhead.

(iii) The compartment over which the step extends does not exceed the permissible length corresponding to a margin line taken 3 inches (or 76 millimetres) below the step.

(f) Where a main transverse bulkhead is recessed or stepped, an equivalent plane bulkhead shall be used in determining the subdivision.

(8) If the distance between two adjacent main transverse bulkheads, or their equivalent plane bulkheads. or the distance between the transverse planes passing through the nearest stepped portions of the bulkheads, is less than 10 feet (or 3.05 metres) plus 3 per cent. of the length of the ship, or 35 feet (or 10.67 metres) whichever is the less, only one of these bulkheads shall be regarded as forming part of the subdivision of the ship in accordance with the provisions of Regulation 5.

(h) Where a main transverse watertight compartment contains local subdivision and it can be shown to the satisfaction of the Administration that, after any assumed side damage extending over a length of 10 feet (or 3.05 metres) plus 3 per cent. of the length of the ship. or 35 feet (or 10.67 metres) whichever is the less, the whole volume of the main compartment will not be flooded, a proportionate allowance may be made in the permissible length otherwise required for such compartment. In such a case the volume of effective buoyancy assumed on the undamaged side shall not be greater than that assumed on the damaged side.

\section{Regulation 7}

\section{Stability of Ships in Dumaged Condition}

(a) Sufficient intact stability shall be provided in all service conditions so as to enable the ship to withstand the final stage of flooding of any one main compartment which is required to be within the floodable length.

Where two adjacent main compartments are separated by a bulkhead which is stepped under the conditions of subparagraph (e) (i) of Regulation 6 , the intact stability shall be adequate to withstand the flooding of those two adjacent main compartments.

Where the required factor of subdivision is .50 or less the intact stability shall be adequate to withstand the fooding of any two adjacent main compartments.

(b) (i) The requirements of paragraph (a) of this Regulation shall be determined by calculations which are in accordance with paragraphs (c), $(d)$ and $(f)$. following, and which take into consideration the proportions and design characteristics of the ship and the arrangement and configuration 
(e) Une cloison transversale principale peut être à baionnette pourvu qu'elle ttisfasse à l'une des conditions suivantes:

(i) La longueur combinée des deux compartiments séparés par la cloison en question n'excède pas 90 pour cent de la longueur envahissable ou deux fois la longueur admissible, avec la réserve, toutefois, que pour les navires ayant un facteur de cloisonnement supérieur à 0,9 la longueur totale des deux compartiments en question ne dépasse pas la longueur admissible.

(ii) Un compartimentage supplémentaire est prévu par le travers de la baionnette pour maintenir le même degré de sécurité que si la cloison était plane.

(iii) Le compartiment au-dessus duquel s'étend la baionnette ne dépasse pas la longueur admissible correspondant à une ligne de surimmersion prise $76 \mathrm{~mm}$. ( 3 pouces) au-dessous de la baionnette.

(f) Lorsqu'une cloison transversale principale présente une niche ou une aiionnette, on la remplacera, dans la détermination du cloisonnement, par une loison plane équivalente.

(g) Si la distance entre deux cloisons transversales principales adjacentes, u entre les cloisons planes équivalentes ou enfin la distance entre deux plans 'erticaux passant par les points les plus rapprochés des baiionnettes, s'il y en a. st inférieure à la plus petite des deux longueurs 3,05 mètres (ou 10 pieds) slus 3 pour cent de la longueur du navire, ou 10,67 mètres (ou 35 pieds), une seule de ces cloisons sera acceptée comme faisant partie du cloisonnement lu navire tel qu'il est prescrit par la Règle 5.

(h) Lorsqu'un compartiment principal étanche transversal est lui-même :ompartimenté, s'il peut être établi à la satisfaction de l'Administration que. lans l'hypothèse d'une avarie s'étendant sur la plus petite des deux longueurs 3,05 mètres (ou 10 pieds) plus 3 pour cent de la longueur du navire, ou 10,67 mètres (ou 35 pieds), l'ensemble du compartiment principal n'est pas :nvahi, une augmentation proportionnelle de la longueur admissible peut itre accordée par rapport à celle qui serait calculée sans tenir compte du :ompartimentage supplémentaire. Dans ce cas, le volume de la réserve de lottabilité supposé intact du côté opposé à l'avarie ne doit pas être supérieur I celui qui est supposé intact du côté de l'avarie.

\section{Règle 7}

\section{Srabilisé des navires en cas d'avarie}

(a) Il devra être prévu, pour le navire intact, daas les diverses conditions d'exploitation, une stabilité telle, qu'après envahissement d'un compartiment principal quelconque restant dans la limite des longueurs envahissables, le navire, au stade final de l'envahissement, puisse satisfaire aux conditions définies ci-dessous.

Lorsque deux compartiments principaux adjacents sont séparés par un cloisonnement avec baionnette répondant aux prescriptions de l'alinéa (e) (i) de la Règle 6. la stabilité à l'état intact doit être telle que le navire satisfasse à ces conditions, avec les deux compartiments adjacents supposés envahis.

Lorsque le facteur de compartimentage prévu est 0,5 , ou moins, la stabilité à l'état intact doit être telle que le navire satisfasse à ces conditions, avec deux compartiments principaux adjacents quelconques envahis.

(b) (i) Les dispositions du paragraphe $(a)$ de la présente Règle seront déterminées conformément aux paragraphes $(c)$. (d) et $(f)$ suivants, par des calculs tenant compte des proportions et des caractéristiques de base du navire. ainsi que de la disposition et de la configuration des compartiments ayant 
of the damaged compartments. In making these calculations the ship is to be assumed in the worst anticipated service condition as regards stability.

(ii) Where it is proposed to fit decks, inner skins or longitudinal bulkheads of sufficient tightness to seriously restrict the flow of water, the Administration shall be satisfied that proper consideration is given to such restrictions in the calculations.

(c) For the purpose of making damage stability calculations the volume and surface permeabilities shall be as follows:-

Spaces

Occupied by Cargo, Coal or Stores

Occupied by Accommodations

Occupied by Machinery ...

lntended for Liquids

\begin{tabular}{ccccc} 
& & \multicolumn{3}{c}{ Permeabil } \\
$\ldots$ & $\ldots$ & $\ldots$ & 60 \\
$\ldots$ & $\ldots$ & $\ldots$ & 95 \\
$\ldots$ & $\ldots$ & $\ldots$ & 85 \\
$\ldots$ & $\ldots$ & \multicolumn{2}{c}{0 or } & 95
\end{tabular}

- Whichever results in the more severe requirements.

(d) Minimum assumed extent of damage shall be as follows:-

(i) Longitudinal extent: $10 \mathrm{ft}$. (or 3.05 metres) plus 3 per cent. of the length of the ship, or 35 feet (or 10.67 metres) whichever is the less.

(ii) Transverse extent (measured inboard from the ship's side, at right angles to the centre line at the level of the deepest sub-division load line) : a distance of one-fifth of the breadth of the ship, as defined in Regulation 2.

(iii) Vertical extent : From top of double bottom up to the margin line.

(iv) If any damage of lesser extent than that indicated in the foregoing sub-paragraphs (i), (ii) and (iii), would result in a more severe condition regarding heel or loss of metacentric height such damage shall be assumed in the calculations.

(e) Unsymmetrical flooding is to be kept to a minimum consistent with efficient arrangements. Where special cross-flooding fittings are provided these, together with the maximum heel before equalisation. shall be acceptable to the Administration. Suitable information concerning the use of such fittings shall be supplied to the master of the ship.

(f) The final conditions of the ship after damage and after equalisation measures have been taken shall be as follows :-

(i) In the case of symmetrical flooding the residual metacentric height shall be positive, except that, in special cases, the Administration may accept a negative metacentric height (upright) provided the resulting heel is not more than seven degrees.

(ii) In the case of unsymmetrical flooding the total heel shall not exceed seven degrees, except that, in special cases, the Administration may allow additional heel due to the unsymmetrical moment, but in no case shall the final heel exceed fifteen degrees.

(iii) In no case shall the margin line be submerged in the final stage of flooding. If it is considered that the margin line may become 
subi une avarie. Pour ces calculs, on considère le navire comme étant dans les plus mauvaises conditions de service possibles du point de vue de la stabilité.

(ii) Lorsqu'il est proposé d'installer des ponts, des doubles coques ou des cloisons longitudinales qui, sans être étanches, sont de nature à retarder sérieusement l'envahissement de l'eau, l'Administration doit donner accord sur la mesure dans laquelle ces dispositions sont de nature à influencer les résultats des calculs.

(c) Pour le calcul de la stabilité en cas d'avarie, on adoptera les perméabilités de volume et de surface suivantes:

\section{Espaces}

Perméabilité

Occupés par les marchandises, le charbon ou les magasins 60

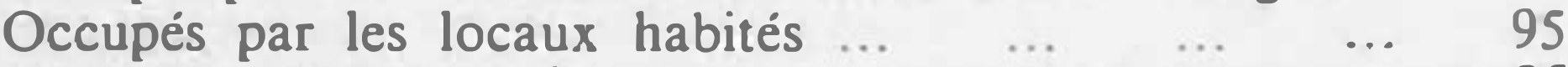

Occupés par des machines $\quad \ldots . \quad \ldots \quad \ldots . \quad \ldots \quad 85$

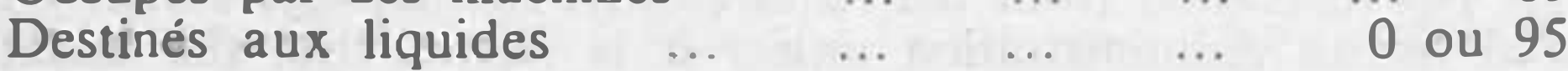

en choisissant pour les deux derniers nombres celui qui entraine les exigences les plus sévères.

(d) On suppose que les dimensions minima de l'avarie considérée sont les suivantes:

(i) Etendue longitudinale : la plus petite des deux valeurs: 3,05 mètres (ou 10 pieds), plus 3 pour cent de la longueur du navire ou 10,67 mètres (ou 35 pieds).

(ii) Etendue transversale (mesurée de la muraille du navire vers l'intérieur et perpendiculairement au plan diamétral au niveau de la ligne de charge maximum de compartimentage: une distance d'un cinquième de la largeur du navire, telle que définie dans la Règle 2.

(iii) Etendue verticale: de la face supérieure du double-fond jusqu'à la ligne de surimmersion.

(iv) Si une avarie d'une étendue inférieure à celle indiquée dans les alinéas précédents (i), (ii) et (iii) entraîne des conditions plus sévères du point de vue de la bande, ou de la hauteur métacentrique résiduelle, une telle avarie sera adoptée comme hypothèse des calculs.

(e) L'envabissement dissymétrique doit être réduit au minimum grâce à des dispositions convenables. Lorsque des traverses d'équilibrage sont prévues, leur disposition, ainsi que la valeur de la bande maxima avant équilibrage, doivent être acceptées par l'Administration. Une documentation convenable concernant l'usage de ces dispositions doit être fournie au Capitaine du navire.

(f) Le navire, dans sa situation définitive après avarie et après que les mesures d'équilibrage ont été prises, doit satisfaire aux conditions suivantes:

(i) En cas d'envabissement symétrique, la bauteur métacentrique résiduelle devra être positive, sauf dans des cas particuliers pour lesquels l'Administration a la faculté d'accepter une hauteur métacentrique négative (navire droit) pourvu que la bande qui en résulte soit inférieure à sept degrès.

(ii) Dans le cas d'un envahissement dissymétrique, la bande totale ne doit pas excéder sept degrés, sauf dans certains cas spéciaux, pour lesquels l'Administration peut autoriser une bande supplémentaire. résultant de l'envahissement dissymétrique, pourvu que, en aucun cas, la bande totale dans le stade final n'excède pas quinze degrés.

(iii) En aucun cas, la ligne de surimmersion ne doit être immergée dans le stade tinal de l'envahissement. S'il est considéré comme 
submerged during an intermediate stage of flooding, the Administration may require such investigations and arrangements as it shall consider necessary for the safety of the ship.

(g) The master of the ship shall be supplied with the data necessary to maintain sufficient intact stability under service conditions to enable the ship to withstand the critical damage. In the case of ships requiring cross-flooding the master of the ship shall be informed of the conditions of stability on which the calculations of heel are based and be warned that excessive beeling might result should the ship sustain damage when in a less favourable condition.

(h) (i) No relaxation from the requirements for damage stability may be considered by an Administration unless it is shown that the intact metacentric height in any service condition necessary to meet these requirements is excessive for the service intended.

(ii) Relaxations from the requirements for damage stability shall be permitted only in exceptional cases and subject to the condition that the Administration is to be satisfied that the proportions, arrangements and other characteristics of the ship are the most favourable to stability after damage which can practically and reasonably be adopted in the particular circumstances.

\section{Regulation 8}

Peak and Machinery Space Bulkheads, Shaft Tunnels. \&c.

(a) (i) A ship shall have a forepeak or collision bulkhead, which shall be watertight up to the bulkhead deck. This bulkhead shall be fitted not less than 5 per cent. of the length of the ship, and not more than 10 feet (or 3.05 metres) plus 5 per cent. of the length of the ship from the forward perpendicular.

(ii) If the ship has a long forward superstructure, the forepeak bulkhead shall be extended weathertight to the deck next above the bulkbead deck. The extension need not be titted directly over the bulkhead below, provided it is at least 5 per cent. of the length of the ship from the forward perpendicular, and the part of the bulkbead deck which forms the step is made effectively weathertight.

(b) An afterpeak bulkhead, and bulkheads dividing the machinery space, as defined in Regulation 2, from the cargo and passenger spaces forward and aft, shall also be fitted and made watertight up to the bulkhead deck, The afterpeak bulkhead may, however, be stopped below the bulkhead deck, provided the degree of safety of the ship as regards subdivision is not thereby diminished.

(c) In all cases stern tubes shall be enclosed in watertight spaces of moderate volume. The stern gland shall be situated in a watertight shaft tunnel or other watertight space separate from the stern tube compartment and of such volume that, if flooded by leakage through the stern gland, the margin line will not be submerged. 
probable, que la ligne de surimmersion se trouve immergée au cours d'un stade intermédiaire de l'envahissement, l'Administration peut exiger toutes études et dispositions qu'elle jugera nécessaires pour la sécurité du navire.

(g) Le Capitaine sera pourvu des données nécessaires pour assurer dans les conditions d'exploitation une stabilité à l'état intact suffisante pour permettre au navire de satisfaire aux conditions ci-dessus dans les hypothèses d'avarie les plus défavorables restant dans le cadre défini plus haut. Dans le cas de navires pourvus de traverses d'équilibrage, le Capitaine du navire doit être informé des conditions de stabilité dans lesquelles les calculs de la bande ont été effectués, et il doit être averti que si le navire se trouvait, à l'état intact, dans des conditions moins avantageuses, il pourrait prendre une bande trop importante en cas d'avarie.

(h) (i) L'Administration ne pourra accorder de dérogation aux exigences concernant la stabilití en cas d'avarie, à moins qu'il ne soit démontré que, dans toute condition d'exploitation, la hauteur métacentrique à l'état intact, résultant de ces exigences, est trop élevée pour l'exploitation envisagée.

(ii) Des dérogations aux prescriptions relatives à la stabilité en cas d'avarie, ne doivent être accordées que dans des cas exceptionnels et sous réserve que l'Administration estime que les proportions. les dispositions et autres caractéristiques du navire, susceptibles d'être pratiquement et raisonnablement adoptées dans des circonstances d'exploitation particulières propres au navire, sont les plus favorables possibles du point de vue stabilité en cas d'avarie.

\section{Règle 8}

\section{Cloisons d'extrémiré, Cloisons limitant la Tranche des Machines, Tunnels des Lignes d'arbres, elc.}

(a) (i) Un navire doit être pourvu d'une cloison de coqueron avant ou d'abordage qui doit être étanche jusqu'au pont de cloisonnement. Cette cloison doit être placée à une distance de la perpendiculaire avant égale au moins à 5 pour cent de la longueur du navire et au plus à 3.05 mètres (ou 10 pieds) plus 5 pour cent de la longueur du navire.

(ii) S'il existe à l'avant une longue superstructure, une cloison étanche aux intempéries doit être établie au-dessus de la cloison d'abordage entre le pont de cloisonnement et le pont situé immédiatement au-dessus. Le prolongement de la cloison d'abordage peut ne pas être placé directement au-dessus de celle-ci, pourvu que ce prolongement soit à une distance de la perpendiculaire avant au moins égale à 5 pour cent de la longueur du navire et que la partie du pont de cloisonnement qui forme baionnette soit effectivement étanche aux intempéries.

(b) Il y aura également une cloison de coqueron arrière et des cloisons séparant la tranche des machines, telle qu'elle est définie par la Règle 2, des espaces à passagers ct à marchandises situés à l'avant et à l'arrière; ces cloisons doivent être étanches jusqu'au pont de cloisonnement. Toutefois, la cloison du coqueron arrière peut être arrêtée au-dessous de ce pont. pourvu que le degré de sécurité du navire en ce qui concerne le compartimentage ne soit pas diminué de ce fait.

(c) Dans tous les cas, les tubes de sortie d'arbres arrière doivent être enfermés dans des espaces étanches de volume modéré. Le presse-étoupe arrière doit être placé dans un tunnel étanche ou dans un autre espace étanche séparé du compartiment des tubes de sortie d'arbres arrière et d'un volume assez réduit pour qu'il puisse être rempli par une fuite du presse-étoupe sans que la ligne de surimmersion soit immergée. 


\section{Regulation 9}

\section{Double Borroms}

(a) A double bottom should be fitted extending from the forepeak bulk head to the afterpeak bulkhead as far as this is practicable and compatible with the design and proper working of the ship.

(i) In ships 200 feet (or 61 metres) and under 249 feet (or 76 metres) in length a double bottom shall be fitted at least from the machinery space to the forepeak bulkhead, or as near thereto as practicable

(ii) In ships 249 feet (or 76 metres) and under 330 feet (or 100 metres) in length a double bottom shall be fitted at least outside the machinery space, and shall extend to the fore and after peals bulkheads, or as near thereto as practicable.

(iii) In ships 330 feet (or 100 metres) in length and upwards a double bottom shall be fitted amidships. and shall extend to the fore and after peak bulkheads, or as near thereto as practicable.

(b) Where a double bottom is required to be fitted the inner bottom shall be continued out to the ship's sides in such a manner as to protect the bottom to the turn of the bilge. Such protection will be deemed satisfactory if the line of intersection of the outer edge of the margin plate with the bilge plating is not lower at any part than a horizontal plane passing through the point of intersection with the frame line amidships of a transverse diagonal line inclined at 25 degrees to the base line and cutting it at a point one-half the ship's moulded breadth from the middle line.

(c) Small wells constructed in the double bottom in connection with drainage arrangements of holds, \&ec., shall not extend downwards more than necessary, nor shall they be less than 18 inches (or 457 millimetres) from the outer bottom or from the inner edge of the margin plate. A well extending to the outer bottom is. however, permitted at the after end of the shaft tunnel of screw ships. Other wells (e.g., for lubricating oil under main engines) may be permitted by the Administration, if satisfied that the arrangements give protection equivalent to that afforded by a double bottom complying with this Regulation.

(d) A double bottom need not be fitted in way of watertight compartments of moderate size used exclusively for the carriage of liquids, provided the safety of the ship, in the event of bottom or side damage, is not, in the opinion of the Administration, thereby impaired.

(e) In the case of ships to which the provisions of paragraph (d) of Regulation 1 of this Chapter apply and which are engaged on regular service within the limits of a short international voyage as defined in Regulation 2 of Chapter Ill, the Administration may permit a double bottom to be dispensed with in any part of the ship which is subdivided by a factor not exceeding .50 . if satisfied that the fitting of a double bottom in that part would not be compatible with the design and proper working of the ship. 


\section{Règle 9}

\section{Doubles-fonds}

(a) Un double-fond doit être installé de la cloison du coqueron avant à la cloison du coqueron arrière, dans la mesure où cela est praticable et compatible avec les caractéristiques et l'utilisation normale du navire :

(i) Les navires dont la longueur est au moins égale à 61 mètres (ou 200 pieds) et inférieure à 76 mètres (ou 249 pieds) doivent être pourvus d'un double-fond s'étendant au moins depuis l'avant de la tranche des machines jusqu'a la cloison du coqueron avant ou aussi près que pratiquement possible de cette cloison.

(ii) Les navires dont la longueur est au moins égale à 76 mètres (ou 249 pieds) et inférieure à 100 mètres (ou 330 pieds) doivent être pourvus de doubles-fonds au moins en dehors de la tranche des machines. Ces doubles-fonds doivent s'étendre jusqu'aux cloisons des coquerons avant et arrière aussi près que pratiquement possible de ces cloisons.

(iii) Les navires dont la longueur est égale ou supérieure à 100 mètres (ou 330 pieds) doivent être pourvus au milieu d'un double-fond s'étendant jusqu'aux cloisons des coquerons avant et arrière ou aussi près que pratiquement possible de ces cloisons.

(b) Là où un double-fond est exigé, il doit se prolonger en abord vers la muraiłle de manière à protéger efficacement les bouchains. Cette protection sera considerée comme satisfaisante si aucun point de la ligne d'intersection de l'arête extérieure de la tôle de côté avec le bordé extericur ne vient au. dessous d'un plan horizontal passant par le point du tracé hors membres où le couple milieu est coupé par une droite inclinée à $25^{\circ}$ sur l'borizontale et menée par le sommet inférieur correspondant du rectangle circonscrit à la maitresse section.

(c) Les petits puisards établis dans les doubles-fonds pour recevoir les aspirations des pompes de cale, ne doivent pas être plus profonds qu'il n'est nécessaire et. en tous les cas, ils ne doivent pas être à moins de 457 millimètres (ou 18 pouces) du bordé extérieur ou du bord intérieur de la tôle de côté. Des puisards allant jusqu'au bordé peuvent cependant étre admis à I'extrémité arrière des tunnels d'arbres des navires à hélice. D'autres puisards (par exemple les tanks de retour d'huile de graissage sous les machines principales) peuvent être autorisés par l'Administration, si elle estime que les dispositions d'ensemble assurent une protection équivalente à celle que fournit un double-fond conforme aux termes de la présente Règle.

(d) Il n'est pas nécessaire d'installer un double-fond par le travers des compartiments étanches de dimensions moyennes, utilisés exclusivement pour le transport des liquides, à condition que, dans l'esprit de l'Administration. la sécurité du navire dans le cas d'une avarie du fond ou du bordé ne s'en trouve pas diminuee.

(e) Dans le cas de navires auxquels s'appliquent les prescriptions du paragraphe $(d)$ de la Règle 1 du présent ctapitre et qui effectuent un service régulier dans les limites prévues pour un voyage international court. à la Règle 2 du Chapitre III, l'Administration peut accorder l'exemption d'un double-fond dans toute partie du navire compartimentée suivant un facteur ne dépassant pas 0.50 . si elle reconnaît que l'installation d'un double-fond dans cette partie ne serait pas compatible avec les caractéristiques de base et l'exploitation normale du navire. 


\section{Regulation 10}

\section{Assigning. Marking and Recording of Subdivision Load Lines}

(a) In order that the required degree of subdivision shall be maintained, a loadline corresponding to the approved subdivision draught shall be assigned and marked on the ship's sides. A ship having spaces which are specially adapted for the accommodation of passengers and the carriage of cargo alternatively may, if the owners desire, have one or more additional loadlines assigned and marked to correspond with the subdivision draughts which the Administration may approve for the alternative service conditions.

(b) The subdivision loadlines assigned and marked shall be recorded in the Safety Certiticate, and shall be distinguished by the notation C.I for the principal passenger condition, and C.2, C.3, \&c., for the alternative conditions.

(c) The freeboard corresponding to each of these loadlines shall be measured at the same position and from the same deck line as the freeboards determined in accordance with the International Convention respecting Load Lines, 1930.( $\left(^{\text {t) }}\right.$

(d) The freeboard corresponding to each approved subdivision loadline and the conditions of service for which it is approved. shall be clearly indicated on the Safety Certiticate.

(e) In no case shall any subdivision loadline mark be placed above the deepest loadline in salt water as determined by the strength of the ship and/or the International Convention respecting Load Lines, 1930.

(f) Whatever may be the position of the subdivision loadline marks, a ship shall in no case be loaded so as to submerge the load line mark appropriate to the season and locality as determined in accordance with the International Convention respecting Load Lines, 1930.

(g) A ship shall in no case be so loaded that when she is in salt water the subdivision loadline mark appropriate to the particular voyage and condition of service is submerged.

\section{Regulation II}

Construction and Initial Testing of Watertight Bulkheads, \&c.

(a) Watertight subdivision bulkheads, whether transverse or longitudinal, shall be constructed in such a manner that they shall be capable of supporting, with a proper margin of resistance, the pressure due to a head of water up to the margin line in way of each bulkhead. The construction of these bulkheads shall be to the satisfaction of the Administration.

(b) (i) Steps and recesses in bulkheads shall be watertight and as strong as the bulkhead at the place where each occurs.

(ii) Where frames or beams pass through a watertight deck or bulkhead, such deck or bulkhead shall be made structurally watertight without the use of wood or cement.

(c) Testing main compartments by filling them with water is not compulsory. A complete examination of the bulkheads shall be made by a suiveyor: and, in addition, a hose test shall be made in all cases.

(d) The forepeak, double bottoms (including duct keels) and inner skins shall be tested with water to a head up to the margin line.

$$
\text { (4) "Treaty Series No. } 35 \text { (1932)." Cind. } 4199 .
$$




\section{Détermination, Marquage el Inscription des Lignes de Churge de Compartimemage}

(a) Pour assurer le maintien du degré de cloisonnement exigé, une ligne Je charge correspondant au tirant d'eau adopté pour le calcul de cloisonnement 3pprouvé doit être déterminée et marquée sur la muraille du navire. Un navire, ayant des locaux spécialement adaptés alternativement à l'usage des passagers et au transport de marchandises, peut, si l'armateur le désire, avoir une ou plusieurs lignes de charge additionnelles, marquées de façon à correspondre aux tirants d'eau de compartimentage correspondants, que l'Administration peut approuver pour les conditions d'exploitation considćrées.

(b) Les lignes de charge de compartimentage déterminées doivent être mentionnées sur le Certificat de Sécurité en désignant par la notation C.I. celle qui se rapporte au cas où le navire est employé principalement au service des passagers, et par les notations C.2, C.3., etc., celles qui se rapportent aux autres cas d'utilisation du navire.

(c) Le franc-bord correspondant à chacune de ces lignes de charge doit être mesuré au même emplacement et à partir de la même ligne de pont que le̊ francs-bords déterminés conformément à la Convention Internationale sur les Lignes de Charge 1930.

(d) Le franc-bord relatif à chaque ligne de charge de compartimentage approuvée et aux conditions d'exploitation correspondantes, doit être clairement indiqué dans le Certificat de Sécurité.

(e) Dans aucun cas, une marque de ligne de charge de compartimentage ne peut être placée au-dessus de la ligne de charge maximum en eau salée correspondant soit à l'échantillonnage du navire, soit à la Convention Internationale sur les Lignes de Charge 1930.

(f) Quelles que soient les positions des marques de lignes de charge de compartimentage, un navire ne doit jamais être chargé de façon à immerger la ligne de charge correspondant à la saison et à la région du globe, tracée conformément à la Convention Internationale sur les Lignes de Charge 1930.

(g) Un navire ne doit en aucun cas être chargé de telle sorte que, lorsqu'il est en eau salée, la marque de ligne de charge de compartimentage. correspondant à la nature de ce voyage particulier et aux conditions de service, se trouve immergée.

\section{Règle 11}

\section{Construction el Epreuves initiales des Cloisons éranches}

(a) Les cloisons étanches de compartimentage, qu'elles soient transversales ou longitudinales, doivent être construites de manière à pouvoir supporter, avec une marge de résistance convenable, la pression due à une colonne d'eau s'élevant jusqu'à la ligne de surimmersion par le travers de chacune d'elles. La construction de ces cloisons doit donner satisfaction à l'Administration.

(b) (i) Les baionnettes et niches pratiquées dans les cloisons doivent être étanches et présenter la même résistance que les parties avoisinantes de la cloison.

(ii) Quand des membrures ou des barrots traversent un pont étanche ou une cloison étanche, ce pont et cette cloison doivent être rendus étanches par leur construction propre, sans emploi de bois ou de ciment.

(c) L'essai par remplissage des compartiments principaux n'est pas obligatoire. Un examen complet des cloisons doit être fait par un inspecteur agréé; cet examen doit être complété, dans tous les cas, par un essai à la lance.

(d) Le coqueron avant. les doubles-fonds (y compris les quilles tubulaires) et les doubles-coques, doivent être sounis à une épreuve sous une hauteur d'eau limitée à la ligne de surimmersion. 
(e) Tanks which are intended to hold liquids, and which form part of the subdivision of the ship. shall be tested for tightness with water to a head up to the deepest subdivision loadline or to a head corresponding to two-thirds of the depth from the top of keel to the margin line in way of the tanks, whichever is the greater; provided that in no case shall the test head be less than 3 feet (or 0.92 metres) above the top of the tank.

$(f)$ The tests referred to in paragraphs $(d)$ and $(e)$ are for the purpose of ensuring that the subdivision structural arrangements are watertight and are not to be regarded as a test of the fitness of any compartment for the storage of oil fuel or for other special purposes for which a test of a superior character may be required depending on the height to which the liquid has access in the tank or its connections.

\section{Regulation 12}

\section{Openings in Wateright Bulkheuds}

(a) The number of openings in watertight bulkheads shall be reduced to the minimum compatible with the design and proper working of the ship; satisfactory means shall be provided for closing these openings.

(b) (i) Where pipes, scuppers. electric cables. \&c.. are carried through watertight subdivision bulkheads. arrangements shall be made to ensure the integrity of the watertightness of the bulkheads.

(ii) Valves and cocks not forming part of a piping system shall not be permitted in watertight subdivision bulkheads.

(c) (i) No doors, manholes, or access openings are permitted-

(a) in the collision bulkhead below the margin line;

(b) in watertight transverse bulkheads dividing a cargo space from an adjoining cargo space or from a permanent or reserve bunker. except as provided in paragraph $(g)$ of this Regulation.

(ii) Except as provided in sub-paragraph (c) (iii) below, the collision bulkhead may be pierced below the margin line by not more than one pipe for dealing with fluid in the forepeak tank, provided that the pipe is fitted with a screwdown valve capable of being operated from above the bulkhead deck. the valve chest being secured inside the forepeak to the collision bulkhead.

(iii) If the forepeak is divided to hold two different kinds of liquids, the Administration may allow the collision bulkhead to be pierced below the margin line by two pipes, each of which is fitted as required by the preceding clause, provided the Administration is satisfied that there is no practical alternative to the fitting of such second pipe and that, having regard to the additional subdivision provided in the forepeak, the safety of the ship is maintained.

(d) (i) Watertight doors fitted in bulkheads between permanent and reserve bunkers, shall be always accessible, except as provided in subparagraph (i) (ii) for between deck bunker doors.

(ii) Satisfactory arrangements shall be made by means of screens or otherwise. to prevent the coal from interfering with the closing of watertight bunker doors. 
(e) Les citernes qui doivent contenir des liquides et qui forment une partie lu compartimentage du navire doivent être éprouvées pour vérification de 'étanchéité sous une charge d'eau correspondant soit à la ligne de charge naximum de compartimentage, soit aux deux tiers du creux mesuré depuis le lessus de la quille jusqu'à la ligne de surimmersion, par le travers de la :iterne, en prenant la plus grande de ces charges: toutefois la hauteur de bharge au-dessus du plafond ne doit être en aucun cas inférieure à $0.92 \mathrm{~m}$. ou 3 pieds).

$(f)$ Les essais mentionnés aux paragraphes $(d)$ et $(e)$ ont pour but de vérifier que les dispositions structurales de cloisonnement sont étanches à l'eau et ae doivent pas être considérées comme sanctionnant l'aptitude d'un compartiment quelconque à recevoir des combustibles liquides ou à ètre utilisé à d'autres usages particuliers pour lesquels un essai d'un caractère plus sévère peut être exigé compte tenu de la hauteur que le liquide peut atteindre dans la citerne considérée ou dans les tuyautages qui la desservent.

\section{Règle 12}

\section{Ouverlures dans les Cloisons étanches}

(a) Le nombre des ouvertures pratiquées dans les cloisons étanches doit être rédujt au minimum compatible avec les dispositions générales et la bonne exploitation du navire; ces ouvertures doivent être pourvues de dispositifs de fermeture satisfaisants.

(b) (i) Si des tuyautages, dalots, câbles électriques, etc., traversent des cloisons étancbes de compartimentage, des dispositions doivent être prises pour maintenir l'intégrité de l'étanchéité de ces cloisons

(ii) Il ne peut exister sur les cloisons étanches de compartimentage ni vannes, ni robinets ne faisant pas partie d'un ensemble de tuyautages.

(c) (i) Il ne peut exister ni porte, ni trou d'homme, ni aucun orifice d'accès:

(a) dans la cloison étanche d'abordage au-dessous de la ligne de surimmersion;

(b) dans les cloisons transversales étanches séparant un local à marchandises d'un local à marchandises contigu ou d'une soute à charbon permanente ou de réserve, sauf exceptions spécifiées au paragraphe (§) de la présente Régle.

(ii) Sauf dans les cas prévus au sous-paragraphe (c) (iii), on peut faire traverser la cloison d'abordage au-dessous de la ligne de surimmersion par un tuyau au plus, pour le service du liquide contenu dans le coqueron avant. pourvu que ce tuyau soit muni d'une vanne à fermeture à vis, commandée d'un point au-dessus du pont de compartimentage et dont le corps sera fixé à la cloison d'ahordage à l'intérieur du coqueron avant.

(iii) Si le coqueron avant est divisé pour recevoir deux espèces de liquides différents, l'Administration peut permettre que la cloison d'ahordage soit traversée au-dessous de la ligne de surimmersion par deux tuyaux, chacun d'eux satisfaisant aux prescriptions de la clause ci-dessus, pourvu que cette Administration reconnaisse qu'il n'y a pas d'autre moyen pratique en dehors de l'installation de ce second tuyau et que. compte tenu du cloisonnement supplémentaire prévu dans la coqueron avant, la sécurité du navire demeure assuree.

(d) (i) Les portes étanches dans les cloisons séparant les soutes permanenltes des soutes de réserve doivent être toujours accessibles, sauf toutefois l'exception prévue au paragraphe (i), (ii) pour les portes des soutes d'entrepont.

(ii) Des dispositions satisfaisantes, au moyen d'écrans ou autrement. doivent être prises pour éviter que le charbon n'empêche la fermeture des portes étanches des soutes à charbon. 
(e) Within the machinery space and apart from bunker and shaft tunnel doors, not more than one door may be fitted in each main transverse bulkhead for intercommunication. These doors shall be of the sliding type and shall be located so as to have the sills as high as practicable. The hand gear for operating these doors from above the bulkhead deck shall be situated outside the machinery space if this is consistent with a satisfactory arrangement of the necessary gearing.

(f) (i) The only types of watertight doors permissible are hinged doors, sliding doors, and doors of other equivalent patterns, excluding plate doors secured only by bolts and doors required to be closed by dropping or by the action of a dropping weight.

(ii) A hinged door shall be fitted with catches workable from each side of the bulkheid.

(iii) A sliding door may have a horizontal or vertical motion. If required to be hand operated only, the gearing shall be operated with an all round crank motion, both at the door and at an accessible position above the bulkhead deck.

(iv) If a door is required to be power operated from a central control, the gearing shall be so arranged that the door can be operated by power also at the door itself. The arrangement shall be such that the door will close automatically if opened by the local control after being closed from the central control and also such that any door can be kept closed by local arrangements which will prevent that door from being opened from the central control. Local control handles in connection with the power gear shall be provided at each side of the bulkhead and shall be so arranged as to enable persons passing through the doorway to hold both handles in the open position. Such power operated doors shall be provided with hand gear, workable both at the door itself and from an accessible position above the tulk. head deck. At the latter position the hand gear shall be operated with an all round crank motion. Provision shall be made to give warning by sound signal when the door is about to be closed: the signal shall precede the movement of the door by a safe interval.

(v) In all classes of doors indicators shall be fitted at all operating stations other than at the donr itself, showing whether the door is opened or closed.

(g) (i) Hinged watertight doors in passenger, crew, and working spaces are only permitted above a deck the underside of whicl, at its lowest point at side, is at least 7 feet (or 2.13 metres) above the deepest subdivision loadline, and they are not permitted in those spaces below such deck.

(ii) Hinged watcrtight doors of satisfactory construction may be fitted in bulkheads dividing cargo between deck spaces, at the highest level consistent with practicability. The outboard vertical edges of such doors shall be situated at a distance from the shell plating which is not less than one-fifth the breadth of the ship, as defined in Regulation 2. such distance being measured at right angles to the centre line of the ship at the level of the deepest sub-division load line. These doors shall be closed before the voyage commences and shall be kept closed during navigation, and the time of opening such doors in port and of rlosing them before the ship leaves port 
(e) Dans la tranche des machines, exclusion faite des portes des soutes charbon et des tunnels de lignes d'arbres, il ne peut exister qu'une porte e communication dans chaque cloison transversale principale. Ces portes oivent étre à glissières et placées de manière que leurs seuils soient pratiqueaent aussi hauts que possible. La commande à main pour la manœuvre le ces portes à partir d'un point se trouvant au-dessus du pont de cloisonneaent, doit être située à l'extérieur de la tranche des machines. si cet aménageaent est compatible avec une disposition satisfaisante du mécanisme corresiondant.

(f) (i) Ne sont admises comme portes étanches que les portes à charnic̀res -t les portes à glissières ou toutes autres portes d'un type équivalent, à exclusion des portes montées simplement sur boulons et des portes se ermant par gravité ou par l'action d'un poids.

(ii) Les portes à charnières doivent être pourvues de tourniquets mancuvrables de chaque côté de la cloison.

(iii) Les portes à glissières peuvent être à déplacement vertical ou 1orizontal. Si elles doivent être seulement commandées à bras, le mécanisme Joit pouvoir être manœuvré sur place, et en outre, d'un point accessible situé au-dessus du pont de cloisonnement, par un mouvement de Inanivelle à rotation continue.

(iv) Lorsqu'il est prévu qu'une porte doit être fermée au moyen d'une source d'énergie, d'un poste central de manœuvre. le mécanisme doit être disposé de manière à permettre la commande de la porte sur place au moyen je la même source d'énergie. La porte devra se refermer automatiquement si. après avoir été fermée du poste de commande central, elle est ouverte sur place. De même, il doit exister sur place un moyen de la maintenir fermée sans qu'clle puisse être ouverte par le poste de commande central. Des poignées de manœuvre locale. communiquant avec le mécanisme mú par une source d'énergie, doivent être prévues de chaque côté de la cloison et doivent être disposées de telle façon qu'une personne passant par la porte puisse maintenir les deux poignées dans la position ouverte. De telles portes inues par une source d'énergie doivent ètre munies d'une commande à main manæuvrable de la porte elle-même et d'un point accessible au-dessus du pont de cloisonnement. A cette dernière position, la commande à main sera manœuvrée par un mouvement de manivelle à rotation continue. Des dispositions doivent être prises pour avertir par un signal sonore que la porte est sur le point de se fermer : l'intervalle de temps entre le signal et le mouvement de la porte doit être suffisant pour assurer toute sécurité.

(v) Les portes de toutes catégories doivent être munies d'indicateurs d'ouverture, permettant de vérifier de tous les postes de commande, autres que sur place, si la porte est ouverte ou fermée.

(g) (i) Des portes étanches à charnières peuvent être admises dans les parties du navire affectées aux passagers et à l'équipage, ainsi que dans les locaux de service, à condition qu'elles soient établies au-dessus d'un pont dont la surface inférieure, à son point le plus bas en abord, se trouve au moins à 2.13 mètres (ou 7 pieds) au-dessus de la ligne de charge maximum de compartimentage: ces portes ne sont pas autorisées dans ces parties et locaux du navire au-dessous d'un tel pont.

(ii) Des portes étanches à charnic̀res de construction satisfaisante peuvent être admises dans les cloisons d'entrepont des locaux à marchandises au niveau le plus élevé permettant encore leur utilisation. Les bords verticaux extérieurs de ces portes ne devront pas être situés à une distance du bordé extérieur inférieure à un cinquième de la largeur du navire telle qu'elle est définie à la Règle 2. cette distance étant mesurée perpendiculairement au plan diamétral du navire au niveau de la ligne de charge maximum de compartimentage. Ces purtes doivent être fermées avant le départ et tenues fermées pendant la navigation, et les heures de leur ouverture à l'arrivée au port et 
shall be entered in such log book as may be prescribed by the Administration Where it is proposed to fit such doors, the number and arrangements shal receive the special consideration of the Administration, and a statement shal be required from the owners certifying as to the absolute necessity of suct doors.

(h) All other watertight doors shall be sliding doors.

(i) (i) When any watertight doors which may be sometimes opened a sea, excluding those at the entrances of tunnels, are fitted in the main trans verse watertight bulkheads at such a height that their sills are below the deepest subdivision loadline, the following rules shall apply:-

(I) When the number of such doors exceeds 5 all the watertight sliding doors shall be power operated and shall be capable of being simultaneously closed from a station situated on the bridge.

(II) When the number of such doors does not exceed 5-

(a) if the criterion numeral does not exceed 30 all the watertight sliding doors may be operated by hand only;

(b) if the criterion numeral exceeds 30 all the watertight sliding doors shall be operated by power:

(c) in any ship, of whatever criterion numeral, if there is only one watertight door apart from the tunnel door, and it is in the machinery space the Administration may allow these two doors to be operated by hand only.

(ii) If watertight doors which have sometimes to be open at sea for the purpose of trimming coal are fitted between bunkers in the between-decks below the bulkhead deck, these doors shall be operated by power. The open. ing and closing of these doors shall be recorded in such log book as may be prescribed by the Administration.

(iii) When trunkways in connection with refrigerated cargo are carried through more than one main transverse watertight bulkhead and the sills of the openings are less than 7 feet (or 2.13 metres) above the deepest subdivision loadline, the watertight doors at such openings shall be operated by power.

(j) Portable plates on bulkheads shall not be permitted except in machincry spaces. Such plates shall always be in place before the ship leaves port, and shall not be removed during navigation except in case of urgent necessity. The necessary precautions shall be taken in replacing them to ensure that the joints shall be watertight.

(k) All watertight doors shall be kept closed during navigation except when necessarily opened for the working of the ship. and shall always be ready to be immediately closed.

(l) (i) Where trunkways or tunnels for access from crew's accommodation to the stokehold, for piping. or for any other purpose are carried through main transverse watertight bulkheads, they shall be watertight and in accordance with the requirements of Regulation 15. The access to at least one end of each such tunnel or trunkway. if used as a passage at sea. shall be through a trunk extending watertight to a height sufficient to permit access above the margin line. The access to the other end of the trunkway or tunnel may be through a watertight door of the type required by its location in the ship. Such trunkways or tunnels shall not extend through the first subdivision bulkhead abaft the collision bulkhead. 
e leur fermeture avant le départ du port doivent être inscrites dans le joumal e hord prescrit par l'Administration. Lorsqu'il existe des portes de cette ature. leur nombre et le détail de leurs dispositions font l'objet d'un examen pécial par l'Administration. Celle-ci exigera de l'armateur une attestation ue cette installation est une nécessité de service absolue.

(h) Toutes les autres portes étanches doivent être à glissières.

(i) (i) Lorsqu'il existe des portes étanches devant être, à certains moments, uvertes à la mer, exception faite de celles des entrées des tunnels, et que ces ortes sont placćes dans les cloisons étanches transversales principales de façon lue leur seuil soit au-dessous de la ligne de charge maximum de compartimenage, les règles suivantes sont appliquées :

(I) Si le nombre de ces portes excède 5 , toutes les portes étanches à glissières doivent être manceuvrées au moyen d'une source d'énergie et pouvoir être fermées simultanément d'un poste de mancuvre situé sur la passerelle.

(II) Si le nombre de ces portes n'excède pas 5:

(a) si le critérium n'excède pas 30, toutes les portes étanches i glissières peuvent être mancuvrées à la main seulement;

(b) si le critérium excède 30 , toutes les portes étanches à glissières doivent être manœuvrées au moyen d'une source d'énergie;

(c) sur tout navire. quel que soit son critérium de service. s'il n'y a qu'une porte étanche, en dehors de la porte du tunnel. et qu'elle se trouve dans la tranche des machines, l'Administration peut autoriser ces deux portes à être manœuvrées à main seulement.

(ii) S'il existe, entre des soutes à charbon dans les entreponts au-dessous du pont de cloisonnement, des portes étanches qui doivent. à la mer, être occasionnellement ouvertes pour la manipulation du charbon, lemploi d'une source d'énergie est exigé pour la manœuvre de ces portes. L'ouverture et la fermeture doivent être mentionnées au journal de bord prescrit par l'Administration.

(iii) L'emploi d'une source d'énergie est également exigé pour la mancuvre des portes établies au passage des conduits des cales frigorifiques, si ces conduits traversent plus d'une cloison transversale principale étanche, et si les seuils de ces portes sont situés à moins de 2,13 mètres (ou 7 pieds) au-dessus de la ligne de charge maximum de compartimentage.

(i) L'emploi de panneaux démontables en tôle n'est toléré que dans la tranche des machines. Ces panneaux doivent toujours être en place avant l'appareillage: ils ne peuvent être enlevés à la mer, si ce n'est en cas d'impérieuse nécessité. Les précautions nécessaires doivent être prises au remontage pour rétablir la parfaite étanchéité du joint.

(k) Toutes les portes étanches doivent être fermées en cours de navigation sauf si le service du navire exige qu'elles soient ouvertes. Dans ce cas elles doivent toujours être prêtes à être immédiatement fermées.

(I) $\mathrm{Si}$ des tambours ou tunnels reliant les logements du personnel aux chaufferies ou disposés pour renfermer des tuyautages ou pour tout autre but, sont ménagés à travers les cloisons transversales étanches, ces tambours ou tunnels doivent être étanches et satisfaire aux prescriptions de la Règle 15. L'accès à l'une au moins des extrémités de ces tunnels ou tambours, si on s'en sert à la mer comme passage, doit être réalisé par un puits étanche d'une hauteur sufisante pour que son débouché soit au-dessus de la ligne de surimmersion. L'accès à l'autre extrémité peut se faire par une porte étanche du type exigé par son emplacement dans le navire. Aucun de ces tunnels ou tambours ne doit traverser la cloison de compartimentage immédiatement eD arrière de la cloison d'abordage. 
(ii) Where it is proposed to fit tunnels or trunkways for forced dra piercing main transverse watertight bulkheads, these shall receive the speci consideration of the Administration.

\section{Regulation 13}

\section{Openings in the Shell Plating below the Margin Line}

(a) The number of openings in the shell plating shall be reduced to $t$ minimum compatible with the design and proper working of the ship.

(b) The arrangement and efficiency of the means for closing any openi in the shell plating shall be consistent with its intended purpose and $t$ position in which it is fitted and generally to the satisfaction of $t$ Administration.

(c) (i) If in a between decks, the sills of any sidescuttles are belowi line drawn parallel to the bulkhead deck at side and having its lowest poif $2 \frac{1}{2}$ per cent. of the breadth of the ship above the deepest subdivision loaline, all sidescuttles in that between deck shall be of a non-opening type.

(ii) All sidescuttles the sills of which are below the margin line, oth than those required to be of a non-opening type by sub-paragraph (c) if shall be of such construction as will effectively prevent any person openif them without the consent of the master of the ship.

(iii) (a) If in a between decks, the sills of any of the sidescuttles referri to in sub-paragraph (c) (ii) are below a line drawn parale to the bulkhead deck at side and having its lowest point $4 \frac{1}{2}$ fdt (or 1.37 metres) plus $2 \frac{1}{2}$ per cent. of the breadth of the stp above the water when the ship departs from any port, all te sidescuttles in that between decks shall be closed watertig and locked before the ship leaves port, and they shall not opened before the ship arrives at the next port. In the applicttion of this sub-paragraph the appropriate allowance for freh water may be made when applicable.

(b) The time of opening such sidescuttles in port and of closing a locking them before the ship leaves port shall be entered in sub log book as may be prescribed by the Administration.

(c) For any ship that has one or more sidescuttles so placed that te requirements of the first clause of this sub-paragraph woid apply when she was floating at her deepest subdivision load lis: the Administration may indicate the limiting mean draught $k$ which these sidescuttles will have their sills above the lie drawn parallel to the bulkhead deck at side, and having lowest point $4 \frac{1}{2}$ feet (or 1.37 metres) plus $2 \frac{1}{2}$ per cent. of $t$. breadth of the ship above the waterline corresponding to 1 limiting mean draught, and at which it will therefore be $\mathrm{p}$. missible to depart from port without previously closing af locking them and to open them at sea on the responsibility the master during the voyage to the next port. In tropi zones as defined in the International Convention respect Load Lines, 1930, this limiting draught may be increased 1 foot (or 0.305 metres).

(d) Efficient hinged inside deadlights arranged so that they can be eas and effectively closed and secured watertight shall be fitted to all sidescutt) 
Lorsqu'il est prévu des tunnels ou tambours pour tirage forcé traversant us cloisons étanches transversales principales, le cas doit être spécialement raminé par l'Administration

\section{Règle 13}

Juverlures dans le Bordé Exlérieur au-dessons de la Ligne de Surimmersion

(a) Le nombre d'ouvertures dans le bordé extérieur doit être réduit au ninimum compatible avec les caractéristiques de base du navire et ses conlitions normales d'utilisation.

(b) La disposition et l'efficacité des moyens de fermeture de toutes les uvertures pratiquées dans le bordé extérieur du navire doivent correspondre u but à réaliser et à l'emplacement oú ils sont fixés; ils doivent, d'une nanière générale. être à la satisfaction de l'Administration.

(c) (i) $\mathrm{Si}$, dans un entrepont, le bord inférieur de l'ouverture d'un hublot quelconque est au-dessous d'une ligne tracée sur le bordé parallèlement au ivet du pont de cloisonnement, et ayant son point le plus bas à $2 \frac{1}{2}$ pour cent He la largeur du navire au-dessus de la ligne de charge maximum de comjartimentage, tous les hublots de cet entrepont doivent être des bublots ixes.

(ii) Tous les hublots dont les bords inférieurs sont en-dessous de la igne de surimmersion, autres que ceux qui, par application du précédent linéa, sont du type fixe. doivent être construits de telle sorte que nul ze puisse les ouvrir sans l'autorisation du Capitaine.

(iii) (a) $\mathrm{Si}$, dans un entrepont le bord inférieur des hublots du type prévu à l'alinéa (c) (ii) ci-dessus, est situé au-dessous d'une ligne tracée parallèlement au livet du pont de cloisonnement. et ayant son point le plus bas à $1 \mathrm{~m} .37$ (ou $4 \frac{1}{2}$ pieds) +2.5 pour cent de la largeur du navire. au-dessus de la flottaison au départ du port. tous les hublots de cet entrepont doivent être fermés de façon étanche et à clef avant l'appareillage et ils ne doivent pas être ouverts avant que le navire n'entre dans un port. 11 y aura lieu. le cas échéant, de tenir compte du fait que le navire est en eau douce.

(b) Les heures d'ouverture de ces hublots dans le port et de leur fermeture à clef avant le départ seront inscrites au journal de bord prescrit par l'Administration.

(c) Si un ou plusieurs hublots sont situés de telle façon que les prescriptions de l'alinéa (c) (iii) (a) leur soient applicables lorsque le navire est à sa ligne de charge maximum de compartimentage. l'Administration peut préciser le tirant d'eau moven le plus élevé pour lequel les hublots en question auront le bord inférieur de leur ouverture au-dessus de la ligne tracée parallèlement au livet du pont de cloisonnement et ayant son point le plus bas à $1 \mathrm{~m} .37$ (4t pieds). plus 2.5 pour cent de la largeur du navire au-dessus de la flottaison du navire correspondant à ce tirant d'eau moyen et pour lequel. par conséquent, il sera permis de prendre la mer sans fermer ces hublots à clef auparavant, et de les ouvrir en mer sous la responsabilité du capitaine au cours du voyage vers le port suivant. Dans les zcnes tropicales, telles qu'elles sont définies dans la Convention internationale de 1930 relative aux lignes de charge, ce tirant d'eau peut êtrc augmenté de 305 millimètres (1 pied).

(d) Des tapes à charnière d'un modèle efficace et disposées de manière a pouvoir être aisément et effectivement fermées et verrouillées étanches. 
except that abaft one-eighth of the ship's length from the forward perpen dicular and above a line drawn parallel to the bulkhead deck at side an having its lowest point at a height of 12 feet (or 3.66 metres) plus $2 \frac{1}{2}$ per cent of the breadth of the ship above the deepest subdivision load line, the dead lights may be portable in passenger accommodation other than that fo f steerage passengers, unless the deadlights are required by the Internationa Convention respecting Load Lines, 1930, to be permanently attached in thei proper positions. Such portable dcadlights shall be stowed adjacent to th sidescuttles they serve.

(e) Sidescuttles and their deadlights, which will not be accessible durin navigation, shall be closed and secured before the ship leaves port.

(v) (i) No sidescuttles shall be fitted in any spaces which are appropriate exclusively to the carriage of cargo or coal.

(ii) Sidescuttles may, however, be fitted in spaces appropriated alte) natively to the carriage of cargo or passengers, but they snaii be of suc construction as will effectively prevent any person opening them or thei deadlights without the consent of the master of the ship.

(iii) If cargo is carried in such spaces, the sidescuttles and their deadligh shall be closed watertight and locked before the cargo is shipped and suc closing and locking shall be recorded in such logbook as may be prescribe by the Administration.

(g) Automatic ventilating sidescuttles shall not be fitted in the shell platin below the margin line without the special sanction of the Administration.

(h) The number of scuppers, sanitary discharges and other similar opening in the shell platiug shall be reduced to the minimum either by making eac discharge serve for as many as possible of the sanitary and other pipes, in any other satisfactory manner.

(i) (i) All inlets and discharges in the shell plating shall be fitted wit efficient and accessible arrangements for preventing the accidenta] admissio of water into the ship.

(ii) (a) Except as provided in sub-paragraph (i) (iii), each separa discharge led through the shell plating from spaces below th margin line shall be provided either with one automatic nol return valve fitted with a positive means of closing it from abor the bulkhead deck, or. alternatively, with two automatic no1 return valves without such means, the upper of which is : situated above the deepest subdivision load line as to be alwa: accessible for examination under service conditions, and is of type which is normally closed.

(b) Where a valve with positive means of closing is fitted, $u$ operating position above the bulkhead deck shall always 1 readily accessible, and means shall be provided for indicatir whether the valve is open or closed.

(iii) Main and auxiliary sea inlets and discharges in connection wi machinery shall be fitted with readily accessible cocks or valves betwei the pipes and shell plating or between the pipes and fabricated boxes attachs to the shell plating.

(j) (i) Gangway, cargo and coaling ports fitted below the margin li shall be of sufficient strength. They shall be effectively closed and securi watertight before the ship leaves port, and shall be kept closed duris navigation. 
oivent être installées sur tous les hublots, sous réserve du fait que, sur arrière du huitième de la longueur du navire à partir de la perpendiculaire vant, et au-dessus d'une ligne tracée parallèlement au livet du pont de loisonnement, et ayant son point le plus bas à $3 \mathrm{~m}$. 66 (ou 12 pieds) +2.5 our cent de la largeur du navire au-dessus de la ligne de charge maximum e compartimentage, les tapes peuvent être amovibles dans les locaux éservés aux passagers, autres que ceux réservés aux passagers d'entrepont. moins que, en vertu de la Convention Internationale de 1930 relative aux ignes de charge, elles ne doivent être inamovibles. Ces tapes amovibles loivent être déposées à proximité des hublots qu'elles sont destinées à ermer.

(e) Les bublots et leurs tapes qui ne sont pas accessibles en cours de lavigation doivent être fermés et condamnés avant l'appareillage.

(f) (i) Aucun hublot ne peut être établi dans les locaux affectés exclusivenent au transport de marchandises ou de charbon.

(ii) Des hublots pourront toutefois être installés dans des espaces affectés Ilternativement au transport de marchandises ou de passagers, mais ils seront :onstruits de telle façon que personne ne puisse ouvrir ces hublots ou leurs apes sans l'autorisation du Capitaine.

(iii) Si des marchandises sont transportées dans ces espaces. les hublots it leurs tapes seront fermés à clef et de façon étanche avant que les marchandises ne soient chargées, et la fermeture et le verrouillage des bublots et des tapes feront l'objet d'une mention au journal de bord prescrit par l'Administration.

(g) Aucun hublot à ventilation automatique ne peut être établi dans le bordé extérieur du navire au-dessous de la ligne de surimmersion, sans autorisation spéciale de l'Administration.

(h) Le nombre de dalots, tuyaux de décharge sanitaire et autres ouvertures similaires dans le bordé extérieur, doit être réduit au minimum, soit en utilisant chaque oritice de décharge pour le plus grand nombre possible de tuyaux, sanitaires ou autres, soit de toute autre manière satisfaisante.

(i) (i) Toutes les prises d'eau et décharges dans le bordé extérieur doivent être disposées de façon à empêcher soute iniroduction accidentelle d'eau dans le navire.

(ii) (a) Sous réserve des dispositions de l'alinéa (i) (iii), chaque décharge séparée partant de locaux situés au-dessous de la ligne de surimmersion et traversant le bordé extéricur, doit être pourvue, soit d'un clapet automatique de non retour muni d'un moyen de fermeture directe. manoeuvrable d'un point situé au-dessus du pont de cloisonnement, soit de deux soupapes automatiques de non-retour sans moyen de fermeture direct. pourvu que la plus élevée soit placée de telle sorte qu'elle soit toujours accessible pour être visitée dans les circonstances de service, et d'un type normalement fermé.

(b) Lorsqu'on emploie des valves à commande de fcrmeture directe, les postes de manoeuvre au-dessus du pont de cloisonnement doivent toujours être facilement accessibles et ils doivent comporter des indicateurs d'ouverture et de fermeture.

(iii) Les prises d'eau et décharges principales et auxiliaires communiquant avec les machines seront pourvues de robinets et de vannes interposés. à des endroits facilement accessibles, entre les tuyaux et le bordé extérieur, ou entre les tuyaux et les caissons fixés sur le bordé extérieur.

(j) (i) Les coupées, portes de chargement et sabords à charbon situés au-dessous de la ligne de surimmersion doivent être de résistance suffisante. lls doivent être efficacement fermés et assujettis avant l'appareillage et rester fermés pendant la navigation. 
(ii) Such ports shall be in no case fitted so as to have their lowest point below the deepest subdivision loadline.

(k) (i) The inboard opening of each ash-shoot, rubbish-shoot, \&ec., shall be fitted with an eflicient cover.

(ii) If the inboard opening is situated below the margin line, the cover shall be watertight, and in addition an automatic non-return valve shall be fitted in the shoot in an easily accessible position above the deepest subdivision loadline. When the shoot is not in use both the cover and the valve shall be kept closed and secured.

\section{Regulation 14}

Construction and Initial Tests of Watertight Doors, Sidescuttles, \&c.

(a)(i) The design, materials and construction of all watertight doors, sidescuttles, gangway. cargo and coaling ports, valves, pipes, ash-shoots and rubbish-shoots referred to in these Regulations shall be to the satisfaction of the Administration.

(ii) The frames of vertical watertight doors shall have no groove at the bottom in which dirt might lodge and prevent the door closing properly.

(iii) Watertight doors giving direct access to any space containing bunker coal shall, together with the frames, be made of cast or wrought steel.

(iv) Cocks or valves of more than 3 inches borc (or 76 millimetres) for main and auxiliary sea inlets and discharges in connection with machinery shall be of steel or bronze as applicable, or other approved ductile material

(v) Ordinary cast iron shall not be used for the other cocks and valves of any size. which are fitted to the shell plating below the bulkhead deck or which affect the subdivision arrangements of the ship.

(b) Each watertight door shall be tested by water pressure to a head up to the margin line. The test shall be made before the ship is put in service, either before or after the door is fitted.

\section{Regulation 15}

Construction and Initial Tests of Watertight Decks. Trunks. \&c.

(a) Watertight decks, trunks, tunnels, duct keels and ventilators shall be of the same strength as watertight bulkheads at corresponding levels. The means used for making them watertight, and the arrangements adopted for closing openings in them, shall be to the satisfaction of the Administration. Watertight ventilators and trunks shall be carried at least up to the bulkhead deck.

(b) After completion, a hose or flooding test shall be applied to watertight decks and a hose test to watertight trunks, tunnels and ventilators. 
(ii) Ces ouvertures ne seront en aucun cas situées de façon que leur oint le plus bas se trouve au-dessous de la ligne de charge maximum de ompartimentage.

(k) (i) Les ouvertures intérieures des manches à escarbilles, manches à lletés, etc., doivent être pourvues d'un couvercle efficace.

(ii) Si ces ouvertures sont situcies au-dessous de la ligne de surimmersion, couvercle doit être étanche, et on doit, en outre, installer dans la manche un apet de non-retour placé dans un endroit accessible au-dessus de la ligne e charge maximum de compartimentage. Quand on ne se servira pas de la tanche, le couvercle et le clapet devront être fermés et assujettis en place.

\section{Règle 14}

Construction et Epreuves Initiales des Portes Etanches. Hublots, elc.

(a) (i) Le tracé, les matériaux utilisés et la construction des portes tanches, hublots, coupées, sabords à charbon, portes de chargement. oupapes, tuyaux, manches à escarbilles et à saletés visés dans les présentes Règles doivent être à la satisfaction de l'Administration.

(ii) Le cadre des portes étanches verticales ne doit présenter à sa rartie inférieure aucune rainure où pourrait se loger de la poussière risquant l'empêcher la porte de se fermer convenablement.

(iii) Les portes étanches donnant directement accès à des espaces ontenant du charbon en soute doivent être, ainsi que leurs cadres, construites n acier moulé ou forgé.

(iv) Les robinets ou vannes, de plus de 76 millimètres (ou 3 pouces) le diamètre intérieur, pour les prises d'eau et décharges principales et uxiliaires desservant la machinerie, doivent être en acier ou en bronze, selon \& cas, ou en toute autre matière peu fragile agréée.

(v) Il ne doit pas être employé de fonte ordinaire pour les autres obinets et vannes, de quelques dimensions que ce soit, quand ils sont lisposés sur le bordé extérieur au-dessous du pont de cloisonnement, ou juand ils intéressent les arrangements relatifs au compartimentage du navire.

(b) Toute porte étanche doit être soumise à un essai à l'eau sous une sression correspondant à la hauteur d'eau jusqu'à la ligne de surimmersion. Let essai doit être fait avant l'entrée en service du navire, soit avant, soit tprès mise en place de la porte à bord.

\section{Règle 15}

\section{Construction et Epreuves Initiales des Ponts Etanclies, Tambours, etc.}

(a) Lorsqu'ils sont étanches, les ponts, tambours, tunnels, quilles ubulaires, et manches de ventilation, doirent être d'un échantillonnage quivalent à celui des cloisons étanches placées au même niveau. Le mode le construction utilisé pour assurer l'étanchéité de ces éléments, ainsi que es dispositifs adoptés pour la fermeture des ouvertures qu'ils comportent. loivent être à la satisfaction de l'Administration. Les manches de ventilation t les tambours étanches doivent s'élever au moins jusqu'au niveau du pont le cloisonnement.

(b) Lorsqu'ils sont étanches, les tambours, tunnels et manches de ventiation doivent être soumis à une épreuve d'étanchéité à la lance après leur :onstruction; l'essai des ponts étanches peut être effectué soit à la lance, soit in les recouvrant d'eau. 


\section{Regulation 16}

Side and other Openings, \&c., above the Margin Line

(a) Sidescuttles, gangway, cargo and coaling ports, and other means fo closing openings in the shell plating above the margin line shall be of efficient design and construction and of sufficient strength having regari to the spaces in which they are fitted and their positions relative to thi deepest subdivision loadline.

(b) The bulkhead deck or a deck above it shall be weathertight in thi sense that in ordinary sea conditions water will not penetrate in a downwars direction. All openings in the exposed weather deck shall have coaming of ample height and strength and shall be provided with efficient means fo expeditiously closing them weathertight.

(c) Freeing ports and ior scuppers shall be fitted as necessary for rapidl) clearing the weather deck of water under all weather conditions.

\section{Regulation 17}

\section{Pumping Arrangements}

(a) Ships shall be provided with an efficient pumping plant, capable of pumping from and draining any watertight compartment under all practicable conditions after a casualty whether the ship is upright or listed. For this purpose wing suctions will generally be necessary except in narrow compartments at the ends of the ship. where one suction may be sufficient. In compartments of unusual form. additional suctions may be required. Arrangements shall be made whercby water in the compartment may find its way to the suction pipes. Efficient means shall be provided for draining water from insulated holds.

(b) (i) Except as provided elsewhere in this Regulation, ships shall have at least three power pumps connected to the bilge main, one of which may be attached to the propelling unit. Where the criterion numeral is 30 or more, one additional independent power pump shall be provided. In ships less than 300 feet (or 91.5 metres) in length and having a criterion numeral less than 30, two efficient hand-pumps of the crank type, fitted one forward and one aft, may be substituted for one of the independent power pumps.

(ii) The requirements are summarised in the following table:-

\begin{tabular}{|c|c|c|c|c|}
\hline Length of ship & \multicolumn{2}{|c|}{$\begin{array}{l}\text { Less than } 300 \text { feet } \\
\text { (or } 91.5 \text { metres) }\end{array}$} & \multicolumn{2}{|c|}{$\begin{array}{l}300 \text { feet (or } 91 \cdot 5 \\
\text { metres) and over }\end{array}$} \\
\hline Criterion numeral & $\begin{array}{c}\text { Less than } \\
30\end{array}$ & $\begin{array}{l}30 \text { and } \\
\text { over }\end{array}$ & $\begin{array}{c}\text { Less than } \\
30\end{array}$ & $\begin{array}{l}30 \text { and } \\
\text { over }\end{array}$ \\
\hline $\begin{array}{l}\text { Hand pumps (may be replaced by } \\
\text { one independent pump) }\end{array}$ & 2 & $\cdots$ & $\cdots$ & $\cdots$ \\
\hline $\begin{array}{l}\text { Main engine pump (may be replaced } \\
\text { by one independent pump) }\end{array}$ & 1 & 1 & 1 & 1 \\
\hline Independent pumps & 1 & 3 & 2 & 3 \\
\hline
\end{tabular}




\section{Règle 16}

ublors el .Autres Ouversures, etc. au-dessus de la Ligne de Surimmersion

(a) Les hublots, les portes de coupées. les portes de chargement, les bords à charbon, et autres dispositifs fermant les ouvertures pratiquées ans le bordé extérieur au-dessus de la ligne de surimnersion. doivent être invenablement dessinés et construits et présenter une résistance suffisante. l égard au compartiment dans lequel ils sont placés et à leur position par pport à la ligne de charge maximum de compartimentage.

(b) Le pont de cloisonnement ou un autre pont situé au-dessus doit être anche, en ce sens que, dans des circonstances de mer ordinaire, il ne laisse as l'eau pénétrer de haut en bas. Toutes les ouvertures pratiquées dans pont exposé à la mer doivent être pourvues de surbaux de hauteur et e résistance suffisantes, et munies de moyens de fermeture efficaces ermettant de les fermer rapidement et de les rendre étanches à la mer.

(c) Des sabords de décharge à la mer et (ou) des dalots doivent être istallés pour évacuer rapidement l'eau des ponts exposés à la mer en jutes circonstances de mer.

\section{Règle 17}

\section{Moyens de Pontpage}

(a) Tout navire doit être pourvu d'une installation de pompage efficace ermettant d'épuiser et d'assécher, dans la mesure pratiquement possible, la suite d'une avarie, un compartiment étanche quelconque, que le navire oit droit ou incliné. A cet effet, des aspirations latérales sont en général écessaires, sauf dans les parties resserrées aux extrémités du navire, où une zule aspiration peut être considérée comme suffisante. Dans les compartiments ui ne sont pas d'une forme usuelle, des aspirations supplémentaires peuvent tre exigées. On prendra les dispositions nécessaires pour assurer l'écoulement e l'eau vers les aspirations du compartiment. Des moyens efficaces doivent tre prévus pour l'épuisement de l'eau des cales frigorifiques.

(b) (i) Sauf dispositions contraires dans une autre partie de la présente Zègle, les navires doivent être pourvus d'au moins trois pompes actionnées yr une source d'énergie et reliées au collecteur principal d'aspiration, l'une l'entre elles pouvant être conduite par la machine principale. Quand le ritérium de service est égal ou supérieur à 30, une pompe indépendante upplémentaire, actionnée par une source d’énergie, doit être prévue. Sur es navires de moins de 91,5 mètres (300 pieds) de longueur, ayant un critérium le service inférieur à 30 , une des pompes indépendantes peut être remplacée jar deux pompes à bras à manivelle, efficaces, placées, l'une à l'avant, l'autre à 'arrière.

(ii) Le tableau ci-dessous donne le nombre de pompes exigibles:-

\begin{tabular}{|c|c|c|c|c|}
\hline \multirow{2}{*}{$\begin{array}{l}\text { Longueur du navire } \\
\text { Critérium de service }\end{array}$} & \multicolumn{2}{|c|}{$\begin{array}{l}\text { Moins de } 91,5 \mathrm{~m} \text {. } \\
\text { (ou } 300 \text { pieds) }\end{array}$} & \multicolumn{2}{|c|}{$\begin{array}{c}91,5 \mathrm{~m} \text {. (ou } 300 \text { pieds) } \\
\text { et au-dessus }\end{array}$} \\
\hline & $\begin{array}{l}\text { moins } \\
\text { de } 30\end{array}$ & $\begin{array}{l}30 \text { et } \\
\text { au-dessus }\end{array}$ & $\begin{array}{l}\text { moins } \\
\text { de } 30\end{array}$ & $\begin{array}{l}30 \text { et } \\
\text { au-dessus }\end{array}$ \\
\hline $\begin{array}{l}\text { Pompes à bras (peuvent ètre rem- } \\
\text { placées par une pompe indépen- } \\
\text { dante) } \\
\text { Pompe conduite par la machine } \\
\text { principale (peut être remplacée } \\
\text { par une pompe indépendante) ... } \\
\text { Pompes indépendantes ... }\end{array}$ & 1 & $\begin{array}{l}1 \\
3\end{array}$ & $\begin{array}{l}1 \\
2\end{array}$ & $\begin{array}{l}1 \\
3\end{array}$ \\
\hline
\end{tabular}


(iii) Sanitary, ballast and general service pumps may be accepted a independent power bilge pumps if fitted with the necessary connections $b$ the bilge pumping system.

(c) Where practicable, the power bilge pumps shall be placed in separat watertight compartments so arranged or situated that these compartments wil not readily be hooded by the same damage. If the engines and boilers are is two or more watertight compartments, the pumps available for bilge servia shall be distributed through these compartments as far as is possible.

(d) On ships 300 feet (or 91.5 metres) or more in length or having : criterion numeral of 30 or more, the arrangements shall be such that at leas one power pump will be available for use in all ordinary circumstances ir which a ship may be flooded at sea. This requirement will be satisfied if-

(i) One of the required pumps is an emergency pump of a reliable submersible type having a source of power situated above the bulkhead deck. or

(ii) The pumps and their sources of power are so disposed throughout the length of the ship that under any condition of flooding which the ship is required to withstand. at least one pump in an undamaged compartment will be available.

(e) With the exception of pumps which may be provided for peak compartments only, each bilge pump, whether operated by hand or by power shall be arranged to draw water from any hold or machinery compartment in the ship.

(f) (i) Each independent power bilge pump shall be capable of giving a speed of water through the main bilge pipe of not less than 400 feet (or 122 metres) per minute. Independent power bilge pumps situated in machinery spaces shall have direct suctions from these spaces, except that not more than two such suctions shall be required in any one space. The Administration may require independent power bilge pumps situated in other spaces to have separate direct suctions. Direct suctions shall be suitably arranged and those in a machinery space shall be of a diameter not less than that of the bilge main.

(ii) In coal-burning ships there shall be provided in the stokehold. in addition to the other suctions required by this Regulation, a fexible suction hose of suitable diameter and sufficient length. capable of being connected to the suction side of an independent power pump.

(g) Main circulating pumps shall have direct suction connections, provided with non-return valves, to the lowest drainage level in the machinery space. and of a diameter at least two-thirds that of the main sea inlet. Where the fuel is. or may be, coal and there is no watertight bulkhead between the engines and the boilers. a direct discharge overboard shall be fitted from at least one circulating pump, or, alternatively, a ty-pass may be fitted to the 
(iii) Les pompes sanitaires, les pompes de ballast ou de service, peuvent e considérées comme des pompes de cale indépendantes si elles sont urvues des liaisons nécessaires avec le réseau du tuyautage de cale.

(c) S'il est pratiquement possible, les pompes de cale actionnées par une urce d'énergie doivent être placées dans des compartiments étanches séparés situés ou disposés de telle sorte qu'une même avarie ne puisse vraisemblableent pas en amener l'envahissement rapide simultané. Si les machines et chaudières sont dans deux ou plus de deux compartiments étanches, les mpes utilisables comme pompes de cale doivent, autant qu'il est possible, e réparties dans ces divers compartiments.

(d) Sur les navires de 91,5 mètres (300 pieds) de longueur ou davantage, dont le critérium de service est égal ou supérieur à 30 , toutes mesures cessaires doivent être prises pour qu'une au moins des pompes mues par une urce d'énergie puisse être utilisée normalement au cas oủ le navire à la er viendrait à être envahi. Cette condition sera considérée comme remplie

(i) une des pompes exigées est une pompe de secours d'un type slibmersible éprouvé, ayant sa source d'énergie située au-dessus du pont de cloisonnement,

ou si:

(ii) les pompes et les sources d'énergie correspondantes sont, réparties sur la longueur du navire de telle manière que, pour tout envahissement que le navire doit être en mesure de supporter, une pompe au moins située dans un compartiment exempt d'avarie puisse être utilisée.

(e) Chaque pompe de cale, qu'elle soit à bras ou actionnée par une source énergie, à l'exception de celles qui sont prévues pour les coquerons seulement, it être disposée pour aspirer dans une cale quelconque ou un compartiment ielconque de la tranche des machines.

$(f)$ (i) Chaque pompe de cale indépendante mue par une source d'énergie it être capable d'imprimer à l'eau, dans le collecteur principal d'aspiration, e vitesse d'au moins 122 métres (ou 400 pieds) par minute. Les pompes de le indépendantes actionnées par une source d'énergie et placées dans la inche des machines, doivent avoir des aspirations directes dans les divers mpartiments de cette tranche, avec cette réserve qu'il ne peut être exigé us de deux aspirations pour l'un quelconque de ces compartiments. Administration peut exiger que les pompes de cale indépendantes actionnées $r$ une source d'énergie et placées dans d'autres compartiments aient des pirations directes séparées. Les aspirations directes doivent être connablement disposées et celles qui sont situées dans un compartiment de la inche des machines doivent être d'un diamètre au moins égal à celui $d u$ llecteur principal d'aspiration.

(ii) Sur les navires chauffant au charbon, on doit installer dans la aufferie, en sus des autres aspirations prévues par la présente Règle, un yau d'aspiration flexible, de diamètre convenable et de longueur suffisante, ii puisse être reliè à l'aspiration d'une pompe indépendante mue par une urce d'énergie.

(g) Les pompes de circulation principales doivent avoir des aspirations rectes munies de clapets de non-retour au point d'aspiration le plus bas de la ambre des machines, et d'un diamètre au moins égal aux deux tiers de celui la prise d'eau principale à la mer. Si le combustible est, ou peut être du arbon, et s'il n'y a pas de cloison étanche entre les machines et les chaudières, ie pompe de circulation au moins doit pouvoir refouler directement à la mer, 
circulating discharge. The spindles of the sea inlet and direct suction valvi, shall extend well above the engine room platform.

(h) (i) All pipes from the pumps which are required for draining care or machinery spaces shall be entirely distinct from pipes which may be use for tilling or emptying spaces where water or oil is carried.

(ii) Lead pipes shall not be used in or under coal bunkers or oil fur storage tanks, or in boiler or machinery spaces, including motor rooms i which oil settling tanks or oil fuel pumping units are situated.

(i) The Administration shall make rules relating to the diameters of th bilge main and branch pipes. The diameter of the bilge main may be dete mined approximately from the following formulre:-

$$
\mathrm{d}=\sqrt{\frac{\mathrm{L}(\mathrm{B}+\mathrm{D})}{2.500}+1}
$$

where $\mathrm{d}=$ internal diameter of the bilge main in inches

$\mathrm{L}=$ length of ship in feet

$\mathrm{B}=$ breadth of ship in feet

$\mathrm{D}=$ moulded depth of ship at bulkhead deck in feet;

$$
d=1.68 \sqrt{ } L \frac{\text { or }}{(B+D)+25}
$$

where $\mathrm{d}=$ internal diameter of the bilge main in millimetres

$\mathrm{L}=$ length of ship in metres

$\mathrm{B}=$ breadth of ship in metres

$\mathrm{D}=$ moulded depth of ship at bulkhead deck in metres.

(4) The arrangement of the bilge and ballast pumping system shall be suc as to prevent the possibility of water passing from the sea and from wate ballast spaces into the cargo and machinery spaces, or from one compartmer to another. Special provision shall be made to prevent any deep tank havio bilge and ballast connections being inadvertently run up from the sea whe containing cargo, or pumped out through a bilge pipe when containing wate ballast.

(k) Provision shall be made to prevent the compartment served by an bilge sustion pipe being flooded in the event of the pipe being severed, $c$ otherwise damaged by collision or grounding, in any other compartment. Fc this purpose. where the pipe is at any part situated nearer the side of the shi than one-tifth the breadth of the ship (measured at right angles to the centr line at the level of the deepest sub-division load line), or in a duct keel. non-return valve shall be titted to the pipe in the compartment containin the open end.

(I) All the distribution boxes, cocks, and valves in connection with th bilge pumping arrangements shall be in positions which are accessible at a times under ordinary circumstances. They shall be so arranged that, in th event of flooding. one of the bilge pumps may be operative on any compar ment. If there is only one system of pipes common to all the pumps, th necessary cocks or valves for controlling the bilge suctions must be workabl from above the bulkhead deck. If, in addition to the main bilge pumpin 
bien un tuyautage direct doit être installé allant à la décharge principale. es tiges de commande de la prise d'eau et des soupapes d'aspiration doivent onter nettement au-dessus du parquet des machines.

(h) (i) Le tuyautage desservant les pompes exigées pour l'epuisement des ompartiments des machines ou des cales à marchandises doit être entièrement istinct du tuyautage employé pour le remplissage ou l'épuisement des ompartiments à eau ou à combustible liquide.

(ii) L'emploi de tuyaux de plomb est interdit à l'intérieur et au-dessous es soutes à charbon et des soutes à combustible liquide, ainsi que dans les ompartiments des machines et dans les chaufferies, y compris les locaux enfermant des pompes à combustible liquide ou des caisses de décantation.

(i) L'Administration doit établir des règles pour le calcul du diamètre u collecteur principal et de ses branchements. Pour la détermination pprochée du diamètre du collecteur principal d'aspiration, on pourra employer is formules suivantes:

$$
d=\sqrt{\frac{L(B+D)}{2500}}+1
$$

où

$\mathrm{d}=$ diamètre intérieur du collecteur principal en pouces

$\mathrm{L}=$ longueur (en pieds) du navire

$B=$ largeur (en pieds) du navire

$\mathrm{D}=$ creux hors membres (en pieds) du navire, mesuré au pont de cloisonnement.

$$
d=1,68 \sqrt{ } \frac{\mathrm{ou}}{\mathrm{L}}(\mathrm{B}+\mathrm{D})+25
$$

$\mathrm{d}=$ diamètre intérieur du collecteur principal en millimètres

$\mathrm{L}=$ longueur (en mètres) du navire

$B=$ largeur (en mètres) du navire

$\mathrm{D}=$ creux hors membres (en mètres) du navire, mesuré au pont de cloisonnement.

$(j)$ la disposition du tuyautage des cales et du tuyautage des ballasts doit être telle que l'eau ne puisse passer de la mer ou des ballasts dans les compartiments des machines ou dans les cales à marchandises, ni d'un compartiment quelconque dans un autre. On doit prendre en particulier des mesures pour éviter qu'une cale à eau ayant des aspirations sur le tuyautage de cale et sur celui des ballasts ne puisse, par inadvertance, être remplie d'eau de mer quand elle contient des marchandises, ou vidée par un tuyau de cale quand elle contient du lest liquide.

(k) Des mesures doivent être prises pour qu'un compartiment desservi par une aspiration de cale ne puisse être envahi dans l'hypothèse où le tuyau correspondant viendrait à être brisé, ou avarié dans un autre compartiment par collision ou par échouage. A cette fin, lorsque le tuyau en question se trouve, en une partie quelconque du navire, à une distance du bordé inférieure à un cinquième de la largeur du navire, mesurée perpendiculairement au plan longitudinal au niveau de la ligne de charge maximum de compartimentage, ou dans une quille tubulaire, il doit être pourvu d'un clapet de non-retour dans le compartiment contenant l'aspiration.

(l) Tous les robinets, vannes, boites de distribution, faisant partie du système d'épuisement des cales, doivent être placés en des endroits où ils soient toujours accessibles dans les circonstances normales. Ils doivent être disposés de telle sorte qu'en cas d'envahissement d'un compartiment, on puisse faire aspirer une pompe de cale dans un compartiment quelconque. S'il n'y a qu'un réseau de tuyaux commun à toutes les pompes, les vannes et robinets qu'il est nécessaire de manœuvrer pour régler les aspirations de cale 
system an emergency bilge pumping system is provided, it shall be inde-do pendent of the main system and so arranged that a pump is capable of operating on any compartment under flooding conditions.

\section{Regulation 18}

\section{Stability Tests for Passenger Ships and Cargo Ships}

(a) Passenger ships and cargo ships shall be inclined upon their completion and the elements of their stability determined. The master shall be supplied with such information on this subject as is necessary to permit efficient handling of the ship, and a copy shall be furnished to the Administration concerned.

(b) The Administration may allow the inclining test of an individual ship to be dispensed with provided basic stability data are available from the inclining test of a sister ship and it is shown 10 the satisfaction of tbe Administration that reliable stability information for the exempted ship can be obtained from such basic data.

\section{Regulation 19}

Periodical Operation and Inspection of Watertight Doors, \&c.

(a) In new and existing ships drills for the operating of watertight doors, sidescuttles, valves and closing mechanisms of scuppers, ash-shoots and rubbish-shoots, shall take place weekly. In ships in which the voyage exceeds one week in duration a complete drill shall be held before leaving port, and others thereafter at least once a week during the voyage, provided that all watertight power doors and hinged doors, in main transverse bulkheads, in use at sea, shall be operated daily.

(b) The watertight doors and all mechanisms and indicators connected therewith, all valves the closing of which is necessary to make a compartment watertight and all valves the operation of which is necessary for damage control cross connections shall be periodically inspected at sea, at least once a week.

\section{Regulation 20}

\section{Entries in Log}

(a) In new and existing ships hinged doors, portable plates, sidescuttles, gangway, cargo and coaling ports and other openings. which are required oy these Regulations to be kept closed during navigation, shall be closed before the ship leaves port. The time of closing and the time of opening (if permissible under these Regulations), shall be recorded in such log book as may be prescribed by the Administration.

(b) A record of all drills and inspections required by Regulation 19 sball be entered in the log book witb an explicit record of any defects which may be disclosed. 
livent pouvoir être commandés d'un point situé au-dessus du pont de jisonnement. Si, en plus du réseau principal de tuyautage de cale, il y a un seau de secours, il doit être indépendant du réseau principal, et disposé de lle sorte qu'une pompe puisse aspirer dans un compartiment quelconque en s d'envahissement.

\section{Règle 18}

\section{Essais de Stabilité pour Navires à passagers et Navires de Charge}

(a) Les navires à passagers et les navires de charge doivent subir, après ur achévement, un essai permettant de déterminer les éléments de leur abilité. Le capitaine recevra à ce sujet tous les renseignements qui lui sont - ¿́cessaires pour utiliser convenablement le navire, et un exenplaire de ces nseignements sera remis à l'Administration.

(b) L'Administration peut dispenser un navire donné de cet essal de abilité pourvu qu'on dispose des éléments de base déduits de l'essai de abilité d'un navire identique et qu'il soit établi à la satisfaction de l'Adminisation que tous les renseignements relatifs à la stabilité du navire en cause zuvent être valablement utilisés.

\section{Règle 19}

Manouvres el Inspections périodiques des Porles Elanches, elc.

(a) Sur tout navire neuf ou existant, il doit être procédé hebdomadairetent à des exercices de manceuvre des portes étanches, des hublots, des bbinets ou vannes et des organes de fermeture des dalots, des manches à icarbilles et des manches à saletés. Sur les navires effectuant des voyages ont la durée excède une semaine, un exercice complet doit avoir lieu avant appareillage, et d'autres ensuite pendant la navigation, à raison d'un au loins par semaine ; toutefois, les portes étanches dont la manœuvre comporte emploi d'une source d'énergie et les portes à charnières des cloisons transersales principales doivent être manœuvrées quotidiennement, lorsqu'elles ont utilisées à la mer.

(b) Les portes étanches, y compris les mécanismes et indicateurs corresondants, ainsi que les soupapes dont la fermeture est nécessaire pour zadre un compartiment étanche, et toutes celles qui commandent la ranœuvre des traverses d'équilibrage utilisables en cas d'avarie, doivent être ériodiquement inspectées à la mer à raison d'une fois au moins par semaine.

\section{Règle 20}

\section{Mentions au Journal de Bord}

(a) Sur tout navire neuf ou existant, les portes à charnières, panneaux émontables, hublots, coupées, portes de chargement, sabords à charbon et utres ouvertures qui doivent rester fermées pendant la navigation, en appliation des présentes Règles, doivent être fermés avant l'appareillage. Mention es heures de fermeture de tous ces organes et des heures auxquelles auront lé ouverts ceux dont les présentes Règles permettent l'ouverture, doit être iite au journal de bord prescrit par l'Administration.

(b) Mention de tous exercices et de toutes inspections prescrits par la règle 19 ci-dessus doit être faite au joumal de bord: toute défectuosité onstatée y est explicitement notée. 


\section{PART C.-ELECTRICAL INSTALLATIONS}

(Part C applies to passenger ships only)

\section{Regulation 21}

\section{General}

(a) Electrical installations in ships shall be such that:-

(i) services essential for safety will be maintained under various emergenc conditions; and

(ii) the safety of passengers, crew and ship from electrical hazards will $b$ assured.

(b) Every ship, the electrical power of which constitutes the only mean of maintaining the auxiliary services indispensable for the propulsion and th safety of the ship, shall be provided witb at least two main generating sets The power of these sets shall be such that it shall still be possible to ensur the functioning of the said services in the event of any one of these generatin sets being stopped.

\section{Regulation 22}

\section{Eimergency Source of Power}

(a) There shall be above the bulkhead deck a self-contained emergenc: source of electrical power. It shall be situated outside the machinery casings The power available shall be sufficient to supply all those services that are, $\mathrm{i}$ the opinion of the Administration, necessary for the safety of the passenger and the crew in an emergency, due regard being paid to such services as ma have to be operated simultaneously. Special consideration shall be given $t$ emergency lighting at every boat station on deck and oversides, in all alleyways: stairways and exits, in the machinery spaces and in the control stations a defined in Regulation 26, and to navigation lights if solely electric. Th power shall be adequate for a period of 36 hours, except that, in the case 0 ships engaged regularly on voyages of short duration, the Administration ma accept a lesser supply if satisfied that the same standard of safety would b attained. The source of emergency power may be either-

(i) an accumulator (storage) battery capable of carrying the emergenc load without recharging or excessive voltage drop; or

(ii) a generator driven by a suitable type of compression ignition engine with an independent fuel supply and with starting arrangement approved by the Administration. The fuel used shall have a flasl point of not less than $110^{\circ} \mathrm{F}$. (or $43 \cdot 3^{\circ} \mathrm{C}$.).

(b) Arrangements shall be such that the emergency plant will functio efficiently when the ship is inclined $22 \frac{1}{2}^{\circ}$ and/or when the trim of the ship i $10^{\circ}$ from an even keel.

(c) (i) Where the emergency power is derived from an accumulator battery arrangements shall be made to ensure that emergency lighting will auto matically come into operation in the event of failure of the main lightin supply. 


\section{PARTIE C.-INSTALLATIONS ELECTRIQUES}

(La partie C s’applique seulement aux navires à passagers)

\section{Règle 21}

\section{Généralités}

(a) Les installations électriques doivent être telles que:

(i) les services essentiels pour le maintien de la sécurité soient assurés en toutes circonstances nécessitant des mesures de secours;

(ii) la sécurité des passagers, de l'équipage et du navire soit assurée à l'égard des accidents d'origine électrique.

(b) Tout navire sur lequel l'électricité constitue le seul moyen d'assurer les services auxiliaires indispensables à sa propulsion et à sa sécurité, doit étre pourvu d’au moins deux groupes électrogènes principaux. La puissance de ces groupes doit être telle qu il soit encore possible d'assurer le fonctionnement des dits services en cas d'arrêt de l'un des groupes.

\section{Règle 22}

\section{Source d'Energie de Secours}

(a) Une source autonome d'énergie électrique doit être placée au-dessus du pont de cloisonnement. Elle doit être située en dehors des tambours de l'appareil propulsif. L'énergie disponible doit être suffisante pour alimenter tous les services que l'Administration considère comme nécessaires à la sécurité des passagers et de l'équipage. au cas oì des mesures de secours doivent être prises, compte tenu des services qui peuvent avoir à fonctionner simultanément. On prendra spécialement en considération l'éclairage de secours aux postes d'embarquement sur le pont et à l'extérieur le long du bord, dans toutes les coursives, escaliers et échappées. dans les compartiments des macbines et dans les postes de sécurité définis à la Règle 26, ainsi que l'alimentation des feux de navigation, si ceux-ci sont exclusivement électriques. L'énergie doit être assurée et maintenue pendant 36 heures. Toutefois, dans le cas de navires effectuant régulièrement des voyages de courte durée, l'Administration peut accepter une alimentation réduite si elle estime qu'on obtient ainsi le même degré de sécurité. La source d'énergie de secours peut être:

soit, (i) une batterie d'accumulateurs capable de supporter la charge de secours sans avoir besoin d'être rechargée et sans cluute excessive de tension;

soit, (ii) une génératrice entraînée par un type approprié de moteur à allumage par compression, muni d'une alimentation indépendante de combustible et d'un système de démarrage approuvé par l'Administration. Le combustible utilisé ne doit pas avoir un point éclair inférieur à $43.3^{\circ} \mathrm{C}$. (ou $110^{\circ} \mathrm{F}$ ).

(b) L'installation de secours doit être réalisée de manière qu'elle puisse fonctionner efficacement lorsque le navire a une bande de $22^{\circ} .5^{\text {avec. simul- }}$ tanément ou non, un angle d'assiette de $10^{\circ}$.

(c) (i) Quand l'énergie électrique de secours provient d'une batterie d'accumulateurs, des dispositions doivent être prises pour assurer la mise en marche automatique d'un éclairage de secours en cas de défaillance de l'alimentation normale. 
(c) (i) All metal sheaths and armour of cables shall be electrically continuous and shall be earthed (grounded).

(ii) Where the cables are neither metal sheathed nor armoured and there might be risk of fire in the event of a n electrical fault, precautions shall be required by the Administration.

(iii) Metal sheathed or armoured cables may be required by the Administration in certain compartments or sections of the ship, with a view to the prevention of fire.

(d) (i) Joints in all conductors except for low voltage communication circuits shall be made only in junction or outlet boxes. All such boxes or wiring devices shall be so constructed as to prevent the spread of fire from the box or device.

(ii) Lighting fittings shall be arranged to prevent temperature rises that would be injurious to the wiring, and to prevent surrounding material from becoming excessively bot.

(e) Wiring shall be supported in such a manner as to avoid chafing or other injury.

(f) Except as provided in paragraph (d) of Regulation 22. each separate circuit shall be protected against overload. The current-carrying capacity of each circuit shall be permanently indicated, together with the rating or setting of the appropriate overload protective device.

(g) (i) Accumulator batteries shall be suitably housed, and compartments used primarily for their accommodation shall be properly constructed and efficiently ventilated.

(ii) Devices liable to arc shall not be installed in a compartment assigned principally to accumulator batteries unless the devices are flameproof (explosion proof).

\section{PART D.-FIRE PROTECTION IN ACCOMMODATION AND SERVICE SPACES}

(Part D applies to passenger ships only)

\section{Regulation 25 \\ Application and General}

(a) The application of this Part of this Chapter is subject to the condition that a ship carrying not more than 36 passengers need comply only with Regulations 28 and 29 provided that, in addition to complying with paragraph (b) of Regulation 50, it is fitted with a fire detection system of a type approved by the Administration, which will automatically indicate at one or more points or stations, where it can be most quickly observed by officers and crew. the presence or indication and location of fire in all enclosed spaces appropriated to the use or service of passengers and crew. except spaces which afford no substantial fire risk.

(b) The main structure, including decks and deck houses, shall be of steel except where the Administration may sanction the use of other suitable material in special cases. It shall be divided into main vertical zones by "A " class bulkheads (as defined later) and further divided by similar bulkheads forming the boundaries protecting spaces which provide vertical access, 
(c) (i) Toutes les gaines et armures métalliques des câbles doivent être ntinues au sens électrique du terme et mises à la masse (à la coque).

(ii) Si les câbles ne sont nj sous gaîne métallique ni armés, et qu’u . uisse y avoir risque d'incendie par suite d'un défaut d'origine électrique, Administration exigera que des précautions spéciales soient prises.

(iii) L'Administration peut imposer, en vue de prévenir l'incendie, des ibles sous gaine métallique ou armés dans certains compartiments ou zrtaines zônes du navire.

(d) (i) Les jonctions de tous les conducteurs, à l'exception des circuits transmission à bas voltage, doivent se faire exclusivement dans des boites \& jonction ou dans des boites de connexion de câbles. Toutes ces boîtes ou ccessoires de câblage doivent être construits de manière à empêcher la ropagation d'un feu prenant sa source à l'intérieur de ces boîtes ou cessoires.

(ii) Les appareils d'éclairage doivent être disposés de manière à viter une élévation de température qui pourrait endommager le câblage et empêcher que les matériaux environnants ne s'échauffent exagérément.

(e) Le câblage doit être supporté de manière à éviter l'usure par frottement u toute autre détérioration.

$(f)$ A l'exception du cas prévu au paragraphe (d) de la Règle 22, chaque ircuit séparé doit être protégé contre les surcharges. L'intensité admissible le chaque circuit doit être indiquée de façon .permanente, ainsi que le alibre ou le réglage du dispositif approprié de protection contre les urcharges.

(g) (i) Les batteries d'accumulateurs doivent être convenablement britées et les compartiments principalement destinés à les contenir doivent tre correctement construits et efficacement ventilés.

(ii) Des dispositifs susceptibles de produire des arcs électriques ne oivent pas être installés dans un compartiment affecté principalement aux ratteries d'accumulateurs, à moins que ces dispositifs ne soient du type nti-déflagrant.

\section{PARTIE D.-PROTECTION CONTRE L'INCENDIE DANS LES LOCAUX HABITES ET LES LOCAUX DE SER VICE}

\section{(La Partie D s'applique aux navires à passagers seulement)}

\section{Règle 25}

\section{Application et dispositions générales}

(a) L'application de cette partie du présent Chapitre fait l'objet d'une éserve pour les navires ne transportant pas plus de 36 passagers. Ces lavires ne sont soumis qu'aux Règles 28 et 29, à condition que, tout en - epondant aux dispositions du paragraphe (b) de la Règle 50. ils soient jourvus d'un dispositif de détection d'incendie d'un type approuvé par 'Administration, dispositif qui indiquera automatiquement en un ou Jlusieurs postes ou emplacements du navire, où ces indications peuvent stre rapidement observées par les officiers et l'équipage, la présence ou les itgnes, ainsi que la localisation, d'un incendie dans tous les locaux fermés reservés à l'usage ou au service des passagers et de l'équipage, à l'exception les locaux qui ne présentent pas de risque important d'incendie.

(b) La structure principale, y compris les ponts et roofs, doit être en acier, sauf dans des cas spéciaux où l'Administration pourra autoriser l'emploi de tout autre matériau approprié.

Cette structure doit être divisée en tranches verticales principales par des cloisons du type "A" (définies plus loin), ces tranches étant subdivisées 
and the boundaries separating the accommodation spaces from the machinery cargo and service spaces and others. In addition, and supplementary to the patrol systems, alarm systems and fire extinguishing apparatus required by Part E of this Chapter, either of the following methods of protection, or : combination of these methods to the satisfaction of the Administration, shal be adopted in accommodation and service spaces with a view to preventing the spread of incipient fires from the spaces of their origin:-

Method I.-The construction of internal divisional bulkheading of " $B$ " class divisions (as defined later) generally without the installation of a detection or sprinkler system in the accommodation and service spaces; or

Method II.- The fitting of an automatic sprinkler and fire alarm system for the detection and extinction of fire in all spaces in which a fire might be expected to originate generally with no restriction on the type of internal divisional bulkheading in spaces so protected; or

Method III.-A system of subdivision within each main vertical zone using " $\mathrm{A}$ " and " $\mathrm{B}$ " class divisions distributed according to the importance, size, and nature of the various compartments, with an automatic fire detection system in all spaces in which a fire might be expected to originate, and with restricted use of combustible and highly inflammable materials and furnishings: but generally without the installation of a sprinkler system.

The detailed requirements are set out in Regulations 27 to 44. The heading of each indicates under which method or methods the Regulation is a requirement.

\section{Regulation 26}

\section{Definitions}

Wherever the phrases defined below occur throughout this Part of this Chapter they shall be interpreted in accordance with the following definitions:-

(a) "Incombustible Material" means a material which neither burns nor gives off inflammable vapours in sufficient quantity to ignite at a pilot flame when heated to approximately $1382^{\circ} \mathrm{F}$. (or $750^{\circ} \mathrm{C}$.). Any other material is a "Combustible Material."

(b) "A Standard Fire Test" is one which develops in the test furnace a series of time temperature relationships approximately as follows:-

$$
\begin{aligned}
& \text { At the end of the first } 5 \text { minutes }-1,000^{\circ} \mathrm{F} \text {. (or } 538^{\circ} \mathrm{C} \text {.) } \\
& " \quad " \quad " \quad 10 \quad " 1,300^{\circ} \mathrm{F} \text {. (or } 704^{\circ} \mathrm{C} \text { ) }
\end{aligned}
$$

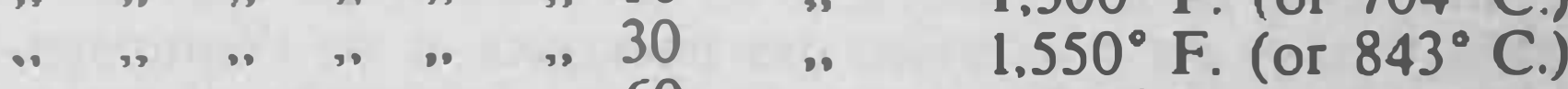

$$
\begin{aligned}
& \text { " " } " \text { " } 60 \text { " } 60 \text { " } 1.700^{\circ} \text { F. (or 927 C.) }
\end{aligned}
$$

(c) " A ' Class or Fire-resisting Divisions" are those divisions formed by bulkheads and decks which comply with the following:-

(i) They shall be constructed of steel or other equivalent material.

(ii) They shall be suitably stiftened. 
es-mêmes par des cloisons similaires assurant la protection des accès rticaux ou constituant les séparations entre les locaux habités et la tranche is machines d'une part et les locaux à marchandises, locaux de service et tres locaux d'autre part. En outre, en plus des services de rondes, des spositifs d'alarme et d'extinction d'incendie tels qu'ils sont prescrits dans partie "E" du présent Chapitrc, l'une ou l'autre des méthodes suivantes protection, ou toute combinaison de ces méthodes acceptée par l'Administion, doit être appliquée dans les locaux habités et les locaux de service, n d'éviter la propagation d'un début d'incendie en dehors du local oi a pris naissance.

Méthode 1.-Construction du cloisonnement divisionnaire intérieur suivant type "B" (détini plus loin) gènéralement sans dispositifs de détection oul d'extinction par pulvérisation d'eau dans les locaux habités et locaux de service.

Méthode Il.- Installation d'un dispositif automatique d'alarme et de pulvérisation d'eau pour la détection et l'extinction de l'incendie dans tous les locaux où un incendie risque de se déclarer, sans aucune restriction en général quant au type de cloisonnements subdivisionnaires à l'intérieur des zones ainsi protégées.

Méthode III.--Construction, à l'intérieur de chacune des tranches verticales, d'un réseau de cloisonnements, constitué par des cloisons des types "A " et "B." réparties selon l"importance. les dimensions et la nature des divers compartiments, avec un système automatique de détection d'incendie dans tous les locaux où un incendie risque de se déclarer, et avec une utilisation restreinte de matériaux et d'accessoires d'emménagement combustibles ou très inflammables, et en général sans installation d'un dispositif automatique d'extinction par pulvérisation d'eau.

Les prescriptions détaillées figurent dans les Règles 27 à 44 dont les titres diquent la méthode ou les méthodes auxquelles elles doivent s'appliquer.

\section{Règle 26 \\ Définitions}

Partout où dans ce Chapitre se présentent les expressions ci-dessous, elles jivent être interprétées comme suit:

(a) "Matériau Incombustible" signifie un matériau qui ne brûle ni n'émet * vapeurs inflammables en quantité suffisante pour s'enflammer au contact une flamme pilote, quand il est porté à une température d'environ $750^{\circ} \mathrm{C}$. ıu $1382^{\circ}$ F.). Tout autre matériau est considéré comme "Matériau ombustible."

(b) "L'essai au feu standard" est un essai au cours duquel, dans le four essai, on réalise approximativement les températures suivantes en fonction 1 temps:

$$
\begin{aligned}
& \text { Au bout des } 5 \text { premières minutes }-538^{\circ} \mathrm{C} \text {. (ou } 1000^{\circ} \mathrm{F} \text {.) } \\
& \text { " " } \quad 10 \quad \text { " } 10 \quad \text {. } \quad-704^{\circ} \text { C. (ou } 1300^{\circ} \text { F.) } \\
& \text { " " "30 " } \quad \text { " } \quad \text { " } \quad-843^{\circ} \text { C. (ou } 1550^{\circ} \mathrm{F} \text {.) } \\
& \text { " " } 60 \quad \text { " " } \quad-927^{\circ} \text { C. (ou 1700 F.) }
\end{aligned}
$$

(c) Les Cloisons Type "A " ou "Cloisons Coupe-feu," sont constituées ar des cloisons et des ponts conformes aux dispositions suivantes:

(i) Elles doivent être construites en acier ou autre matériau équivalent. (ii) Elles doivent être convenablement armaturées. 
(iii) They shall be so constructed as to be capable of preventing it passage of smoke and flame up to the end of the one-hour standar fire test.

(iv) They shall have an insulating value to the satisfaction of the Admini: tration, having regard to the nature of the adjacent spaces. I general, where such bulkheads and decks are required to forn fire-resisting divisions between spaces either of which contair adjacent woodwork, wood lining, or other combustible materia they shall be so insulated that, if either face is exposed to th standard fire test for one hour, the average temperature on th unexposed face will not increase at any time during the test $b$ more than $250^{\circ} \mathrm{F}$. (or $139^{\circ} \mathrm{C}$.) above the initial temperature no shall the temperature at any one point rise more than $325^{\circ} \mathrm{F}$. (c $180^{\circ}$ C.) abuve the initial tempcrature. Reduced amounts insulation or none at all may be provided where in the opinion s the Administration a reduced fire hazard is present.

(d) " 'B' Class or Fire-retarding Divisions" are those divisions forme by bulkheads which are so constructed that they will be capable of preventin the passage of flame up to the end of the first one-half hour of the standar fire test. In addition they shall have an insulating value to the satisfactic of the Administration, having regard to the nature of the adjacent space In general, where such hulkheads arc required to form fire-retarding divisior between cabins, they shall be of material which, if either face is exposed fo the first one-half hour period of the standard fire test, will prevent the ten perature on the unexposed side from increasing during the test by more tha $250^{\circ} \mathrm{F}$. (or $139^{\circ} \mathrm{C}$.) above the initial temperature. For panels which are incombustible materials it will only be necessary to comply with the abov temperature rise limitation during the first 15 -minute period of the standar fire test, but the test shall be continued to the end of the one-half hour test the panel's integrity in the usual manner. Reduced amounts of insulatio or none at all may be provided where in the opinion of the Administration reduced fire hazard is present.

(e) "Main Vertical Zones" are those sections into which the hull, supe structure, and deck houses are divided by main fire-resisting bulkheads, th mean length of which above the bulkhead deck does not, in general, excee 131 feet (or 40 metres).

(f) "Control Stations" are those spaces in which radio, main navigatin or central fire-recording equipment or the emergency generator is located.

(g) "Accommodation" spaces are those used for public spaces, corridor lavatories, cabins, offices, crew quarters, barber shops, isolated pantries an lockers, and similar spaces.

(h) "Public Spaces" are those portions of the accommodation which as used for halls, dining rooms, lounges, and similar permanently enclose spaces.

(i) "Service Spaces" are those used for galleys, main pantries, stort (except isolated pantries and lockers). mail and specie rooms, and simili spaces and trunks to such spaces. 
(iii) Elles doivent être construites de façon à pouvoir empêcher le passage de la fumée et des flammes à la tin de l'essai d'une heure au feu standard.

(iv) Elles doivent présenter un degré d'isolation suivant des règles ćtablies par l'Administration, compte tenu de la nature des locaux contigus. En règle générale, lorsque des cloisons et des ponts de ce genre sont exigés pour constituer des cloisonnements résistant au feu entre des locaux dont l'un ou l'autre comportent des lambourdages. des revêtements en bois, ou d'autres matériaux combustibles en contact avec la cloison. ils doivent être isolés de telle façon, que s'ils sont soumis pendant une heure à l'essai au feu standard, la température moyenne de la surface non exposée, quelle que soit celle-ci, n'augmente à aucun moment au cours de l'essai de plus de $139^{\circ} \mathrm{C}$. (ou $250^{\circ} \mathrm{F}$.) au-dessus de la tempćrature initiale, et que la température en un point quelconque ne s'élève pas de plus de $180^{\circ} \mathrm{C}$. (ou $325^{\circ}$ F.) au-dessus de la température initiale. Lisolation peut étre réduite ou supprimée complètement aux endroits où l'Administration reconnait qu'il y a un risque d'incendie moindre.

(d) Les cloisons Type "B." ou cloisons écrans retardant la propagation e l'incendie. sont constituées par des cloisons construites de manière à ouvoir empêcher le passage des flammes jusqu'à la fin de la première demieure de l'essai au feu standard. En outre, elles doivent présenter un degré isolation conforme aux exigences de l'Administration, compte tenu de la ature des locaux avoisinants. En règle générale, lorsque des cloisons de ce enre sont exigées pour constituer des cloisonnements retardant la propagation e l'incendie entre des cabines, elles doivent être construites en matériaux ui, soumis pendant la première période d'une demi-heure à l'essai au feu tandard, empêcheront la température de la face non-exposée, quelle que oit celle-ci, de s'élever, au cours de l'essai, de plus de $139^{\circ} \mathrm{C}$. (ou $250^{\circ} \mathrm{F}$.) u-dessus de la température initiale. Lorsque les panneaux constitutifs sont n matériaux incombustibles, il suffira de vérifier que la condition d'élévation le température mentionée ci-dessus est réalisée au bout des 15 premières ninutes de l'essai au feu standard, mais l'essai devra être poursuivi jusqu'à la in des trente minutes, afin de vérifier, de la manjère habituelle, l'intégrité lu panneau.

L'isolation peut être réduite ou supprimée complètement, lorsque l'Adninistration reconnaît qu'il y a un moindre risque d'incendie.

(e) Les "Tranches Verticales Principales" sont les zônes qui résultent de a division de la coque, de la superstructure et des roofs par des cloisons rincipales résistant au feu. Leur longueur moyenne, au-dessus du pont de zloisonnement, ne dépasse pas en règle générale 40 mètres (ou 131 pieds).

(f) Les "Postes de Sécurité" sont les locaux dans lesquels sont placés les appareils de radio. ou les appareils principaux de navigation, ou les installations centrales de détection et de signalisation d'incendie, ou la génératrice de secours.

(g) Les "Locaux Habités" comprennent les locaux de réunion, les coursives, les locaux sanitaires, les cabines, les bureaux, les locaux affectés à l'équipage, les salons de coiffure, les offices isolés, armoires de service ou locaux similaires.

(h) Les "Locaux de Réunion" sont les parties des locaux habités qui comprennent les halls, salles à manger, salons et autres locaux similaires, isolés de l'extérieur du navire d'une façon permanente.

(i) Les "Locaux de Service" comprennent les cuisines, les offices principaux les magasins (sauf les cffices isolés et les armoires de service). les soutes à dépêches, les soutes à valeurs, et les locaux similaires, ainsi que les entourages de descente qui y conduisent. 
(i) "Cargo Spaces" are all spaces used for cargo (including cargo o tanks) and trunks to such spaces.

(k) "Machinery Spaces" include all spaces used for propelling, auxiliar or refrigerating machinery, boilers, pumps, workshops, generators, ventilatio and air conditioning machinery, oil filling stations, and similar spaces an trunks to such spaces.

(l) "Steel or Other Equivalent Material."-Where the words "steel other equivalent material " occur, "equivalent material" means any materi which, by itself or due to insulation provided, has integrity properties equiva lent to steel at the end of the applicable fire exposure (e.g., aluminium wit appropriate insulation).

\section{Regulation 27}

\section{Siructure (Methods I, II and III)}

The hull, superstructure, structural bulkheads, decks and deckhouses sha be constructed of steel, except where the Administration may sanction th use of other suitable material in special cases.

\section{Regulation 28}

\section{Main Verical Zones (Methods I. II and III)}

(a) The hull, superstructure and deck houses shall be subdivided b "A" Class divisions into main vertical zones, the mean length of whic above the bulkhead deck shall not in general exceed 131 feet (or 40 metres) Where steps are necessary they shall be of "A " Class divisions.

(b) As far as practicable the portions of such bulkheads above the bulk head deck shall be in line with watertight subdivision bulkheads situater immediately below the bulkhead deck.

(c) Such bulkheads shall extend from deck to deck and to the shell o other boundaries.

(d) On ships designed for special purposes, such as automobile or rail road car ferries, where installation of such bulkheads would defeat the purpose for which the ship is intended, equivalent means for controlling and limiting a fire shall be substituted and specifically approved by the Administration.

\section{Regulation 29}

Openings in Main Vertical Zone Bulkheads (Methods I, II and III)

(a) Where main vertical zone bulkheads are pierced for the passage ol electric cables, pipes, trunks, \&c., or for girders, beams or other structures arrangements shall be made to ensure that the fire-resistance of the bulkheads is not impaired.

(b) Dampers are to be fitted in trunks passing through main vertical zone bulkheads and shall be fitted with suitable local control capable of being operated from both sides of the bulkhcad. The operating positions 
(i) Les "Locaux à Marchandises" comprennent tous les locaux utilisés sur les marchandises (y compris les citernes à fret liquide) ainsi que les tourages de panneaux qui y aboutissent.

(k) Les "Locaux de Machines" comprennent tous les locaux contenant ippareil propulsif, les machines auxiliaires ou les machines frigorifiques, les taudières, les pompes. les ateliers, les génératrices, les installations de ventilaon et de conditionnement d'air, les postes de mazoutage et les locaux milaires, ainsi que les entourages des panneaux qui y aboutissent.

(l) "Acier ou autre Matériau équivalent." Toutes les fois que se ésentent les mots "acier ou autre matériau équivalent" il faut comprendre ut matériau qui, de lui-même ou par isolation, possède des propriétés intégrité équivalentes à celles de l'acier, après avoir été exposé au feu endant le temps exigé (par exemple l'aluminium, isolé de manière spropriée).

\section{Règle 27}

\section{Structure (Méthodes I. II el III)}

La coque, les superstructures, les cloisons de structure, les ponts et les jofs doivent être construits en acier, sauf dans les cas spéciaux où Administration pourra autoriser l'emploi de tout autre matériau approprié.

\section{Règle 28}

\section{Tranches verticales principales (Méthodes I, II et III)}

(a) La coque, les superstructures et les roofs doivent être divisés par des loisons du type "A" en tranches verticales principales dont la longueur hoyenne au-dessus du pont de cloisonnement ne doit pas, en règle générale, épasser 40 mètres (ou 131 pieds). Là oì des baïonnettes sont nécessaires. eur construction doit être du type "A."

(b) Dans la mesure du possible, les portions de ces cloisons qui se trouvent u-dessus du pont de cloisonnement, doivent être à l'aplomb des cloisons tanches de compartimentage situées immédiatement au-dessous du pont de loisonnement.

(c) Ces cloisons doivent s'étendre de pont à pont, jusqu'au bordé :xtérieur ou autres entourages.

(d) A bord des navires destinés à des services spéciaux. tels que le transort d'automobiles et de wagons de chemin de fer, sur lesquels la contruction des cloisons de ce genre serait incompatible avec l'utilisation de ces lavires, des moyens équivalents permettant de maîtriser et de localiser incendie seront admis en remplacement des dispositions réglementaires avec 'approbation spéciale de l'Administration.

\section{Règle 29}

Juveriures pratiquées dans les Cloisons des Tranches verticales principales d'Incendie

\section{(Méthodes I. II et III)}

(a) Lorsque les cloisons des tranches verticales principales d'incendie sont percées pour le passage de câbles électriques, de tuyaux, de conduits, etc., ou pour des hiloires, des barrots ou autres éléments de la structure de la zoque, des dispositions doivent être prises pour que la résistance de ces loisons au feu ne soit pas compromise.

(b) Des volets de fermeture doivent être installés dans les conduits raversant les cloisons des tranches verticales principales d'incendie et doivent être munis d'un dispositif convenable de commande locale susceptible d'être 
shall be readily accessible and marked in red. Indicators shall be fitted t show whether the dampers are open or shut.

(c) All openings shall be provided with permanently attached means ( closing which shall be at least as elfective for resisting fires as the bulkheac in which they are fitted.

(d) The construction of all doors and doorways in main vertical zone bull heads, with the means of securing them when closed. shall provide fir resistance at least as effective as the bulkheads in which the doors are situate and must be capable of resisting the passage of smoke and flame. Watertigl doors need not be insulated.

(e) It shall be possible to open each door from either side of the bulkhea by one person only. Fire doors other than watertight doors shall be of th self-closing type with simple and easy means of release from the open position These doors shall be of types and designs approved by the Administration.

\section{Regulation 30}

Bulkheads within Main V'ertical Zones (not required for Method II)

\section{(a) Merhod I}

(i) Within the accommodation spaces, all enclosure bulkheads, other tha those required to be of "A " class divisions, shall be constructed of " $B$ class divisions and assembled in such a manner as to ensure the integrity $c$ the unit. The Administration may require an assembly test. On ships whic carry more than 100 passengers the "B " class divisions shall be of incon bustible materials which may, however, be faced with combustible material in accordance with Regulation 39.

(ii) All corridor bulkheads shall extend from deck to deck. Ventilatio openings will be permitted in the corridor bulkheads, preferably in the lowe portion. All other enclosure bulkheads shall extend from deck to dec vertically, and to the shell or other boundaries transversely. unless incom bustible ceilings or linings are fitted, in which case the bulkheads may te? minate at the ceilings or linings.

\section{(b) Method III}

(i) Within the accommodation spaces enclosure bulkheads other than thos required to be of "A " class divisions shall be constructed of " $B$ " clas divisions so as to form a continuous network of fire retarding bulkhead within which the area of any one compartment shall not in general excee 1,300 square feet (or 120 square metres) with a maximum of 1.600 square fee (or 150 square metres).

(ii) All public spaces without interior subdivisions shall be surrounde by " B " class bulkheads. The insulation of "A " class and "B" clas divisions except those constituting the separation of the main vertical zones, th control stations, the stairway enclosures, and the corridors, may be omitte where the divisions constitute the outside part of the ship or when th adjoining compartment does not contain fire hazard. 
tín anœuvré des deux côtés de la cloison. Les postes de manœuvre de ces rans doivent être facilement accessibles et repérés en rouge. Des indicateurs ouverture et de fermeture doivent être installés.

(c) Toutes les ouvertures doivent être munies de moyens de fermeture tachés de manière permanente à la cloison et dont la résistance au feu jit être au moins égale à celle de cette cloison principale.

(d) La structure de toutes les portes et encadrements de portes dans les oisons des tranches principales d'incendie, ainsi que les dispositifs permettant e maintenir ces portes fermées. doivent pouvoir résister au feu d'une manière 4 moins aussi efficace que les cloisons dans lesquelles ces portes sont ratiquées et doivent également pouvoir empêcher le passage de la fumée des flammes. 11 n'est pas nécessaire d'isoler les portes étanches.

(e) Chacune de ces portes doit pouvoir être ouverte de chaque côté de cloison par une seule personne. Les portes d'incendie autres que les ortes étanches doivent pouvoir se fermer d'elles-mêmes, avec un moyen imple et facile de déclenchement du verrouillage qui les maintient dans la osition ouverte. Le type et les plans de ces portes doivent être approuvés ar l'Administration.

\section{Règle 30}

:loisons situées à l'intérieur des Tranches verticales principales d'Incendie (non exigées pour la Mérhode II)

\section{o) Méthode I}

A l'intérieur des locaux habités, toutes les cloisons d'entourage, autres jue celles qui doivent être des cloisons du type "A." doivent être du type B," et assemblées de manière à assurer l'intégrité de l'ensemble. L'Adminisration peut imposer, sur l'ensemble monté, un essai du maintien de cette ntégrité au feu. Sur les navires qui transportent plus de 160 passagers. les loisons de la classe "B" doivent être d'un matériau incombustible, qui peut ependant être revêtu d'un matériau combustible. en conformité avec la Règle 39.

Toutes les cloisons de coursives doivent s'étendre de pont à pont. Les Juvertures de ventilation seront autorisées dans les cloisons de coursives. de préférence dans la partie inférieure. Toutes les autres cloisons d'entourage Joivent s'étendre de pont à pont dans le sens vertical, et jusqu'au bordé extérieur ou aux autres limites transversales, à moins que l'installation ne comporte des plafonds ou des revêtements incombustibles, auquel cas les cloisons peuvent se limiter aux plafonds ou revêtements.

\section{(b) Mérhode III}

A l'intérieur des locaux habités, les cloisons d'entourage, autres que celles wh qui doivent être constituées par des cloisons du type "A." doivent être du "type "B," construites de manière à former un réseau continu de cloisons susceptibles de retarder la propagation de l'incendie, et à l'intérieur duquel la superficie d'un compartiment quelconque ne doit pas dépasser en général 120 mètres carrés (1300 pieds carrés), avec un maximum de 150 mètres carrés (1600 pieds carrés).

Tous les locaux publics sans cloisonnements intérieurs doivent être entourés de cloisons du type "B." L'isolation des cloisons des types "A " et "B," sauf en ce qui concerne celles qui séparent les tranches verticales principales, les postes de sécurité, les entourages d'escalier et les coursives, peut être supprimie partout où les cloisonnements constituent la partic extérieure du navire, ou quand le compartiment adjacent ne présente pas de risque d'incendie. 
(iii) All corridor bulkheads shall be of "B" class divisions and shall extend from deck to deck. When no ceilings are fitted or when the ceilings are of incombustible materials ventilation openings having grilles of incombustible material will be permitted. All other enclosure bulkheads shall also extend intact from deck to deck.

(iv) The "B" class divisions shall be of a type having incombustible cores or of an assembled type having internal layers of sheet asbestos or similar incombustible material, and the temperature rise limitation referred to in the definition of "B" class divisions in Regulation 26 shall apply at the end of the half hour test.

\section{Regulation 31}

Separusion of Accommodasion Spaces from Machinery. Cargo and Service Spaces (Meshods I, II and III)

The boundary bulkheads and decks separating accommodation spaces from machinery, cargo and service spaces shall be constructed as "A "class divisions, and these bulkheads and decks shall have an insulation value to the satisfaction of the Administration having regard to the nature of the adjacent spaces.

\section{Regulation 32}

Deck Coverings (Meshods I, II and III)

Primary deck coverings within accommodation spaces, control stations, stainvays and corridors shall be of material which will not readily ignite and as approved by the Administration.

\section{Regulation 33}

\section{Protection of Versical Srainways}

(a) Methods I and III

(i) All stairways shall be of steel frame construction and shall be within enclosures formed of "A " class divisions, with positive means of closure at all openings from the lowest accommodation deck at least to a level which is directly accessible to the open deck, except that:-

(a) A stairway serving only two decks need not be enclosed provided the integrity of the deck is maintained by proper bulkheads or doors at one level.

(b) Stairways may be fitted in the open in a public space provided they lie wholly within such public space.

(ii) Stairway enclosures shall have direct communication with the corridors and be of sufficient area to prevent congestion having in view the number of persons likely to use them in an emergency, and shall contain as little accommodation or other enclosed space in which a fire may originate as practicable. 
Toutes les cloisons de coursives doivcnt être constituées par des cloisons du type "B," et doivent s'étendre de pont à pont. Lorsqu'il n'y a pas de plafond, ou lorsque les plafonds sont construits d'un matériau incombustible, on autorisera des ouvertures de ventilation munies d'un grillage incombustible. Toutes les autres cloisons d'entourage doivent également s'étendre intégralement de pont à pont.

Les cloisonnements du type "B" doivent être d'un type à âme incombustible ou d'un type composite, comportant à l'intérieur des couches de feuilles d'amiante ou de matériaux incombustiles analogues, et la limite d'élévation de température à laquelle on se réfère dans les définitions des cloisons du type "B" à la Règle 26, doit être observée à la fin de l'essai de 30 minutes au feu standard.

\section{Règle 31}

Séparation entre les locaux habités d'une part et les locaux de machines, les locaux à marchandises et les locaux de service d'autre part

Les cloisons et ponts qui séparent les locaux habités des locaux de machines, des locaux à marchandises et des locaux de service, doivent être construits suivant le type des cloisons "A," et ces cloisons et ponts doivent avoir un degré d'isolation jugé satisfaisant par l'Administration intéressée, eu égard à la nature des locaux adjacents.

\section{Règle 32}

\section{Revêrements de Ponts}

(Méthodes I, II et III)

Les sous-couches constituant les revêtements des ponts à l'intérieur des locaux habités, des postes de sécurité, des escaliers et des coursives, doivent être en matériaux ne s'enflammant pas spontanément et approuvés par l'Administration.

\section{Règle 33}

\section{Protection des Escaliers}

\section{(a) Méthodes l et III}

(i) Tous les escaliers doivent avoir une charpente en acier et être disposés dans des entourages constitués de cloisons du type "A." munis de moyens efficaces de fermeture de toutes les ouvertures, et s'étendant depuis le pont d'emménagement le plus bas jusqu'au moins à une hauteur d'où l'on peut accéder directement au pont découvert, sauf les exceptions suivantes:

(a) Il n'est pas nécessaire de prévoir d'entourage pour les escaliers qui desservent seulement deux entreponts, à condition que l'intégrité du pont découpé par la descente soit maintenue, au moyen de cloisons ou de portes convenables, dans l'un ou l'autre des deux entreponts.

(b) Des escaliers peuvent être installés sans entourage dans un local de réunion, à condition qu'ils se trouvent complètement à l'intérieur de ce local.

(ii) Les entourages d'escalier doivent avoir une communication directe avec les coursives et enclore une superficie suffisante pour empêcher l'embouteillage, compte tenu du nombre de personnes susceptibles de les utiliser en cas d'urgence. Ils doivent contenir le moins possible de locaux habités ou autres locaux fermés dans lesquels un incendie peut prendre naissance. 
(iii) Stairway enclosure bulkheads shall have an insulation value to the satisfaction of the Administration, having regard to the nature of the adjacent spaces. The means for closure at openings in stairway enclosures shall be at least as effective for resisting fre as the bulkheads in which they are fitted. Doors other than watertight doors shall be of the self-closing type, as required for the main vertical zone bulkheads.

\section{(b) Merhod II}

(i) Main stairways shall be of steel frame construction and shall be within enclosures formed of "A " class divisions with positive means of closure at all openings from the lowest accommodation deck at least to a level which is directly accessible to the open deck except that:-

(a) A stairway serving only two decks need not be enclosed provided the integrity of the deck is maintained by proper bulkheads or doors at one level:

(b) Stairways may be fitted in the open in a public space provided they lie wholly within such public space.

(ii) Stairway enclosures shall have direct communication with the corridors and be of sufficient area to prevent congestion having in view the number of persons likely to use them in an emergency, and shall contain as little accommodation or other enclosed space in which a fire may originate as practicable.

(iii) Stairway enclosure bulkheads shall have an insulation value to the satisfaction of the Administration, having regard to the nature of the adjacent spaces. The means for closure at openings in stairway enclosures shall be at least as effective for resisting fire as the bulkheads in which they are fitted. Doors other than watertight doors shall be of the selfclosing type, as required for the main vertical zone bulkheads.

(iv) Auxiliary stairways shall be of steel frame construction but need not be within enclosures provided the integrity of the deck is maintained by the fitting of sprinklers at the auxiliary stairways.

\section{Regulation 34}

Protection of Lifts (Passenger and Service). Verlical Trunks for Light and Air. \&c. (Methods $I, I I$ and $I I I$ )

(a) Passenger and service lift trunks, vertical trunks for light and air to passenger spaces, \&c., shall be of "A" class divisions. Doors shall be of steel or other incombustible material and when closed shall provide fire resistance at least as effective as the trunks in which they are fitted.

(b) Lift trunks shall be so fitted as to prevent the passage of smoke and flame from one between deck to another and shall be provided with means of closing so as to permit of draught and smoke control. The insulation of lift trunks which are within stairway enclosures shall not be compulsory. 
(iii) Les entourages d'escalier doivent avoir un degré d'isolation jugé satisfaisant par l'Administration. compte tenu de la nature des locaux adjacents.

Les dispositifs de fermeture des ouvertures des entourages d'escaliers doivent avoir une résistance au feu au moins aussi efficace que les cloisons dans lesquelles ces ouvertures sont pratiquées. Les portes, autres que les portes étanches. doivent pouvoir se fermer d'elles-mèmes, comme il est prescrit pour les cloisons des tranches verticales principales.

(b) Méthode II

(i) Les escaliers principaux doivent avoir une charpente en acier et doivent se trouver dans des entourages constitués par des cloisons du type " A," avec des moyens de fermeture à toutes les ouvertures depuis le pont d'emménage. ment le plus bas jusqu'au moins à une hauteur d'où l'on peut accéder directement au pont découvert, sauf les exceptions suivantes:

(a) Il n'est pas nécessaire de prévoir d'entourage pour les escaliers qui desservent seulement deux entreponts à condition que l'intégrité du pont découpé par la descente soit maintenue au moyen de cloisons ou de portes convenables, dans l'un ou l'autre des deux entreponts.

(b) Des escaliers peuvent être installés sans entourage dans un local de réunion. à condition qu'ils se trouvent entièrement à l'intérieur de ce local.

(ii) Les entourages d'escalier doivent avoir une communication directe avec les coursives et enclore une superficie suffisante pour empêcher l'embouteillage, compte tenu du nombre de personnes susceptibles de les utiliser en cas d'urgence. Us doivent contenir le moins possible de locaux habités ou autres locaux fermés dans lesquels un incendie peut prendre naissance.

(iii) Les cloisons qui enferment les escaliers doivent avoir un degré d'isolation jugé satisfaisant par l'Administration. compte tenu de la nature des locaux adjacents. Les moyens de fermeture des ouvertures des entourages d'escaliers doivent avoir une résistance au feu au moins aussi efficace que les cloisons dans lesquelles ces ouvertures sont pratiquées. Les portes autres que les portes étanches doivent pouvoir se fermer d'elles-mêmes comme il est prescrit pour les cloisons des tranches verticales principales.

(iv) Les escaliers secondaires devront comporter des charpentes en acier, mais ne seront pas nécessairement à l'intérieur d'entourages. à condition que l'intégrité des ponts découpés par ces escaliers soit maintenue par l'installation de dispositifs d'extinction par pulvérisation dans ces escaliers.

\section{Règle 34}

Protection des Ascenseurs et Monte-charges, Puits d'Eclairage, d'Aération, etc. (Méthodes $1, I I$ et III)

(a) Les cages des ascenseurs et monte-charges, les puits d'éclairage et d'aération desservant les locaux habités, etc., doivent être constitués de cloisons du type "A." Les portes doivent être en acier ou en un autre matériau incombustible, et. lorsqu'elles sont fermées, doivent assurer une résistance au feu au moins aussi efficace que celle des entourages sur lesquels elles sont disposées.

(b) Les cages des ascenseurs doivent être disposées de manière à empêcher la fumée et les flammes de passer d'un entrepont à un autre et doivent être munies de dispositifs de fermeture, permettant de limiter le tirage et le passage des fumées. L'isolation des cages d'ascenseurs qui se trouvent à l'intérieur des entourages d'escaliers n'est pas obligatoire. 
(c) Where a trunk for light and air communicates with more than one between deck space, and in the opinion of the Administration, smoke and flame are likely to be conducted from one between deck to another, smoke shutters, suitably placed, shall be fitted so that each space can be isolated in case of fire.

(d) Any other trunks (e.g. for electric cables) shall be so constructed as not to afford passage for fire from one between deck or compartment to another.

\section{Regulation 35}

Protection of Control Stations (Methods I, II and III)

Control stations shall be separated from the remainder of the ship by "A " class bulkheads and decks.

\section{Regulation 36}

Protection of Store Rooms, \&c. (Methods I. II and III)

The boundary bulkheads of baggage rooms, mail rooms, store rooms, paint and lamp lockers. galleys, and similar spaces shall be of "A "class divisions. Spaces containing highly inflammable stores shall be so situated as to minimise the danger to passengers or crew in the event of fire.

\section{Regulation 37}

\section{Windows and Sidescutiles}

\section{(a) Methods I and III}

All windows and sidescuttles within accommodation spaces shall be constructed with metal frames or equivalent material. The glass shall be retained by a metal glazing bead or equivalent means. All windows or sidescuttles opening on to corridors or stairways shall conform to the integrity requirements of the type of bulkheads in which they are fitted.

\section{(b) Method II}

All windows or sidescuttles opening on to corridors or stairways shall conform to the integrity requirements of the type of bulkhead in which they are fitted.

\section{Regulation 38}

\section{Ventilation Systems (Methods I, II and III)}

(a) The main inlets and outlets of all ventilation systems shall have accessible means of closure which can be shut in the event of fire. In general, the ventilating fans shall be so disposed that the ducts reaching the various quarters shall remain within the same main vertical zone.

(b) All power ventilation, except machinery space ventilation, shall be fitted with master controls so that all fans may be stopped from either of two control stations which should be situated as far apart as practicable. One of the master controls of the power ventilation serving machinery spaces shall be operable from a position outside the machinery space. Efficient insulation shall be provided for exhaust ducts from galley ranges where the ducts pass through accommodation spaces. 
(c) Dans le cas où un puits d'aération ou d'éclairage communique avec plus d'un entrepont, et lorsque, suivant l'opinion de l'Administration, les fumées et les flammes risquent de passer d'un entrepont à l'autre, des écrans contre la fumée doivent être installés de manière que chacun des locaux se trouve isolé en cas d'incendie.

(d) Tous les autres conduits (par exeınple, pour les câbles électriques) doivent être construits de façon à ne pas permettre à un incendie de se propager entre plusieurs entreponts ou plusieurs compartiments.

\section{Règle 35}

Protection des Postes de Sécurité (Méthodes I, II et III)

Les postes de sécurité doivent être séparés des autres régions du navire par des cloisons et des ponts du type "A."

\section{Règle 36}

Protection des Magasins, elc. (Méthodes I, Il el III)

Les cloisons d'entourage de soutes à bagages, soutes à dépèches, magasins à peinture, lampisteries, cuisines et autres locaux similaires doivent étre du type "A." Les locaux contenant des objets ou un matériel éminemment inflammables doivent être situés de manière à réduire le danger pour les passagers ou l'équipage en cas d'incendie.

\section{Règle 37}

\section{Fenêrres et Hublots}

\section{(a) Méthodes I et III}

Toutes les fenêtres et hublots à l'intérieur des locaux habités doivent être construits avec des cadres en métal ou en un matériau équivalent. Le vitrage doit être assujetti dans un encadrement avec couvre-joints métalliques ou avec un dispositif équivalent. Toutes les fenêtres ou hublots ouvrant sur les coursives ou sur les escaliers doivent répondre aux prescriptions d'intégrité des cloisons sur lesquelles ils sont disposés.

\section{(b) Méthode II}

Toutes les fenêtres et hublots ouvrant sur les coursives ou les escaliers doivent répondre aux prescriptions d'intégrité des cloisons sur lesquelles ils sont disposés.

\section{Règle 38}

\section{Sysièmes de Ventilation (Méthodes I, II et III)}

(a) Les orifices d'arrivée d'air frais ou d'aspiration d'air vicié doivent avoir des moyens de fermeture accessibles pouvant être manouvrés en cas d'incendie. D'une manière générale, les ventilateurs doivent être disposés de façon que les conduits débouchant dans les divers locaux restent à l'intérieur de la même tranche verticale principale.

(b) Tous les appareils de ventilation mécanique, à l'exception des ventilateurs des locaux de machines, doivent être nuunis d'une commande principale telle que l'on puisse arrêter tous les ventilateurs de l'un ou l'autre de deux postes de commande aussi éloignés l'un de l'autre qu'il est pratiquement possible. L'une des commandes principales des appareils de ventilation mécanique desservant des locaux de machines doit pouvoir être manœuvrée de l'extérieur de ces locaux. Lin isolement efficace doit être prévu pour les conduits d'évacuation des fourneaux des cuisines, partout où ces conduits traversent des locaux habités. 


\section{Regulation 39}

Details of Construction (not required for Method II)

\section{(a) Method I}

Except in cargo spaces, mail rooms, baggage rooms or refrigerated compartments of service spaces, all linings, grounds, ceilings, and insulations, shall be of incombustible materials, but in ships carrying not more than 100 passengers the linings, grounds and ceilings need not be of incombustible materials provided they conform to the conditions applicable to the bulkheads of the spaces in which they are situated. The total volume of combustible facings, mouldings, decorations, and veneers in any accommodation or public space shall not exceed a volume equivalent to one-tenth inch (or 2.54 millimetres) veneer on the combined area of the walls and ceiling. Combustible facings, mouldings, decorations or veneers shall not be used in corridors or stairway enclosures.

\section{(b) Meshod III}

The use of combustible materials of all kinds such as untreated wood, veneers, ceilings, curtains, carpets, \&c., shall be reduced in so far as it is reasonable and practicable. In large public spaces the grounds and supports to the linings and ceilings, shall be of steel or equivalent material.

\section{Regulation 40}

\section{Miscellaneous Items (Methods I, II and III)}

(a) (i) Air spaces enclosed behind ceilings, panellings or linings shall be suitably divided by close-fitting draught stops not more than 45 feet (or 13.73 metres) apart in the fore and after direction.

(ii) In the vertical direction, such spaces, including those behind linings of stairways, trunks, \&ec., shall be closed at each deck.

(b) The construction of ceiling and bulkheading shall be such that it will be possible for tbe fire patrols to detect any smoke originating in concealed and inaccessible spaces without impairing the efficiency of the fire protection.

(c) The concealed surfaces of all bulkheads, linings, panellings, stairways, wood grounds, \&c., in accommodation spaces shall be such as will, in the opinion of the Administration, restrict the spread of flame to a satisfactory degree.

(d) Paints, varnishes and similar preparations having a nitro-cellulose base shall not be used.

(e) Lead shall not be used for overhoard scuppers, sanitary discharges and other outlets which are close to the water line nor where the fusing of the lead in the event of fire would give rise to danger of fooding.

(f) Electric radiators, if used, must be fixed in position and so constructed as in reduce fire risks to a minimum. Electric radiators of the exposed element type shall not be used. 
Règle 39

Détails de Construction (non exigés pour la Méshude II)

(a) Méthode l

Sauf dans les locaux à marchandises, les soutes à dépêches, soutes à bagages et les chambres à vivres réfrigérées. tous les revêtements, semelles, lambourdages, plafonds et isolations devront être constitués en materiaux incombustibles. Toutefois, à bord des navires ne transportant pas plus de 100 passagers. il n'est pas nécessaire que les vaigrages, semelles. lambourdages et plafonds soient constitués en matériaux incombustibles, pourvu qu'ils soient conformes aux prescriptions relatives aux cloisons des locaux dans lesquels ils sont situés.

Le volume total des éléments combustibles: revêtements, moulures. décorations et placages dans tout local habité ou local de réunion, ne doit pas dépasser un volume éauivalent au volume d'un placage de 2,54 millimètres (1/10 pouce) d'épaisseur, recouvrant la surface totale des parois et du plafond. Dans les entourages d'escaliers et cloisons des coursives, les éléments combustibles sont interdits pour la constitution des vaigrages, moulures, décorations ou placages.

\section{(b) Mérhode III}

On doit réduire autant qu'il est pratique et raisonnable l'emploi des matériaux combustibles de tous genres, tels que les bois, placages, éléments de plafonds, rideaux, tapis, non protégés contre le feu. Dans les grands locaux de réunion, les semelles, le lambourdage des parois et des plafonds et les supports divers doivent être en acier ou en matériau equivalent.

\section{Règle 40}

\section{Détails Divers (Méthodes I, II et III)}

(a) (i) Les lames d'air et espaces vides se trouvant derrière les boiseries, ou entre ponts et plafonds doivent être convenablement divisés par des écrans bien ajustés, pour éviter les tirages. Leur écartement ne doit pas dépasser 13,70 mètres (45 pieds) dans le sens longitudinal.

(ii) Dans le sens vertical, ces espaces, y compris ceux qui se trouvent derrière les vaigrages des entourages, escaliers, puits, etc. . .., doivent être fermés à chaque pont.

(b) La construction des plafonds et des cloisonnements doit être telle qu'elle permette aux rondes d'incendie de découvrir toute fumée provenant d'espaces dissimulés et inaccessibles, sans que l'efficacité de la protection contre l'incendie en soit diminuée.

(c) Les surfaces non apparentes de tous les vaigrages, cloisons, boiseries. escaliers, lambourdages, etc. ..... dans les locaux habités, doivent être tels qu'ils présentent un pouvoir limité de propagation de la flamme, à la satisfaction de l'Administration.

(d) Les peintures, vernis, et autres substances analogues, à base de nitrocellulose, ne doivent pas être employés.

(e) Le plomb ne doit pas être employé dans la construction des dalots extérieurs et boîtes de décharge sur bordé, des décharges sanitaires et autres conduits d'évacuation situés près de la ligne de charge, de même que partout où la fusion du plomb, en cas d'incendie, créerait des dangers d'envahissement.

(f) Les radiateurs électriques, s'il y en a à bord. doivent être fixés à demeure et construits de façon à réduire au minimum les risques d'incendie. Il est interdit d'employer des radiateurs électriques du type à feu ouvert. 
Required only for Method III

(g) All exposed surfaces and their coatings in accommodation spaces shall be of limited flame-spreading power to the satisfaction of the Administration.

\section{Regulation +1}

\section{Cinematograph Apparatus (Methods I, II and III)}

Except where only "non-inflammable" film is used the installation and use of cinematograph apparatus on ships shall be subject to special fire precautions to be prescribed by the Administration. Lockers for the storage of highly inflammable film shall have an outlet to the open air with a total area of 1 square inch for each 5 lbs. (10 square centimetres for each 3.5 kilogrammes) reel of film or equivalent stored therein.

\section{Regulation 42}

Automatic Sprinkler and Fire Alarm and Detection Systems (Method II)

In ships in which method II is adopted, an automatic sprinkler and fire alarm system of a type approved by the Administration and complying with the requirements of Regulation 48 shall be installed and so arranged as to protect all enclosed spaces appropriated to the use or service of passengers or crew, except spaces which afford no substantial fire risk.

\section{Regulation 43}

\section{Automatic Fire Alarm and Fire Detection Systems (Method III)}

In ships in which method III is adopted a fire detecting system of a type approved by the Administration shall be installed and so arranged as to detect the presence of fire in all enclosed spaces appropriated to the use or service of passengers or crew (except spaces which afford no substantial tire hazard) and automatically to indicate at one or more points or stations, where it can be most quickly observed by officers and crew, the presence or indication and location of fire.

\section{Regulation 44}

\section{Plans (Methods I, II and III)}

There shall be permanently exhibited. for the guidance of the officer in charge of the ship, general arrangement plans showing for each deck the various fire sections enclosed by fire-resisting bulkheads, the sections enclosed by fire-retarding bulkheads (if any). together with particulars of the firc alarms, detecting systems, the sprinkler installation (if any). the fire-extinguishing appliances, means of ingress to and egress from different compartments, decks. \&c.. and the ventilating system including the positions of dampers and identification numbers of the ventilating fans serving each section. 
'rescription s'appliquant seulement à la Méthode III

$(g)$ Toutes les surfaces apparentes des locaux habités, ainsi que lcurs snduits ou revêtements, doivent avoir un pouvoir propagateur de flamme imité. à la satisfaction de l'Administration.

\section{Règle 41}

\section{Appareils cinématographiques (Méthodes I. II et III)}

Sauf dans les cas oì l'on n'utilıse que des films "ininflammables," l'installation et l'utilisation d'appareils cinématographiques à bord des navires à passagers doivent être soumises à des précautions spéciales contre l'incendie, prescrites par l'Administration. Les armoires et magasins où sont placés les films très inflammables doivent être pourvus d'un conduit aboutissant à l'air libre, ayant une section totale de $2,85 \mathrm{~cm}^{2}$ par kilogramme (1 pouce carré par 5 livres) de bobines de film ou de matièrc équivalente entreposées.

\section{Règle 42}

Dispositif automatique d'extinction par pulvérisation d'eau. Sy'stème Avertisseur d'incendie et Système de détection (Méthode (I)

A bord des navires utilisant la Méthode Il, on doit installer un dispositif automatique d'extinction par pulvérisation d'eau et un système avertisseur d'incendie d'un type approuvé par l'Administration et conforme aux Dispositions de la Règle 48 . Ces installations sont disposées de façon à protéger tous les locaux fermés affectés à l'usage ou au service des passagers ou de l'équipage. à l'exception des locaux ne présentant pas un risque notable d'incendie.

\section{Règle $\mathbf{4 3}$}

Avertisseurs d'Incendie automatiques et Dispositifs de Détection d'Incendie (Mérhode III)

Sur les navires où l'on utilise la Méthode III, on doit installer un dispositif de détection d'incendie, d'un type approuvé par l'Administration, qui sera installé de façon à permettre de découvrir la présence d'un incendie dans tous les locaux fermés affectés à l'usage et au service des passagers ou de l'équipage (à l'exception des locaux qui ne présentent pas un risque notable d'incendie). Cette installation doit signaler automatiquement en un ou plusieurs endroits ou postes de sécurité du navire (ou les officiers et les membres de l'équipage peuvent observer arec le plus de rapidité) la présence ou l'indication d'un incendie. ainsi que son emplacement.

\section{Règle t4}

\section{Plans (Méthodes 1 , II er III)}

Des plans d'ensemble seront affichés en permanence à l'usage de l'Officier de service du navire: ils indiqueront l'emplacement. sur chaque pont, des diverses cloisons d'incendie du type coupe-feu, des zones limitées par des cloisons écrans retardant la propagasion de l'incendie (s'il y en a). ainsi que tous renseignements utiles sur les avertisseurs d'incendie, les dispositifs de détection, les extincteurs automatiques par pulvérisation d'eau (s'il y en a). les dispositifs d'extinction d'incendie, les moyens d'entrée et de sortie des divers compartiments, ponts, etc, et l'installation de ventilation, y compris la position des volets de fermeture et les numéros d'identification des ventilateurs deservant chaque zone. 
PART E.-FIRE DETECTION AND EXTINCTION IN PASSENGER SHIPS AND CARGO SHIPS

(Part E applies to passenger ships and cargo ships except that Regulation 50 applies only to passenger ships and Regulation 51 applies only to cargo ships)

NorE.-Regulations 45 to 49 inclusive set forth the conditions with which the appliances mentioned in Regulations 50 and 51 are required to comply

\section{Regulation 45}

\section{Pumps, Water Service Pipes, Hydrants and Hoses}

(a) Fire pumps shall be independently driven. Sanitary, ballast, bilge or general service pumps may be accepted as fire pumps. In any ship the capacity of the pumps designated for fre-fighting purposes shall be at least two-thirds the capacity of the bilge pumps required for the particular ship. Each pump shall be capable of producing at least the two powerful jets to which reference is made in these Regulations. The throw at any nozzle shall be about 40 feet (or 12 metres).

(b) Relief valves shall be provided in connection with all tire pumps. These valves shall be so placed and adjusted as to prevent excessive pressure in any part of the fire main system.

(c) The diameter of the water service pipes shall be sufficient to ensure an adequate supply of water for the simultaneous operation of at least two fire hoses. and shall be based on the required capacity of the pumps designated for fire-fighting purposes.

(d) The number and position of the hydrants shall be such that at least two streams of water, one of which shall be from a single length of hose, may be directed into any part of the ship.

(e) The pipes and hydrants shall be so placed that the fire hoses may be easily coupled to them. In ships where deck cargo may be carried, the positions of the hydrants shall be such that they are alway's readily accessible and the pipes shall be arranged as far as practicable to avoid risk of damage by such cargo.

(f) Cocks or valves shall be fitted in such positions on the pipes that any of the fire hoses may be removed while the fre pumps are at work.

(g) Fire hoses shall be of material approved by the Administration, and sufficient in length to project a jet of water to any of the spaces in which they may be required to be used. They shall be provided with the necessary fittings. The internal diameter of the nozzle shall be not less than $\frac{1}{2}$ inch (or 12 millimetres).

(h) Hoses specified in these Regulations as "fire hoses" shall, together with any necessary fittings and tools, be kept ready for use in conspicuous positions near the water service hydrants or connections. 


\section{PARTIE E.-DETECTION ET EXTINCIION DE LINCENDIE SUR}

\section{LES NAVIRES A PASSAGERS ET LES NAVIRES DE CHARGE}

La parie E est applicable aux navires à passagers et aux navires de charge. l'exception de la Règle 50 qui ne s'applique qu'aux navires à passagers. t de la Règle 51 qui ne s'applique quaux navires de charge. Les dispositions des Règles 45 à 49 incluses sont applicables aux appareils et instalations mentionnés dans les Règles 50 et 51 .

\section{Règle 45}

\section{Pompes. Tuyautages d'Eau de Mer. Prises d'Incendie et Manches}

(a) Les pompes d'incendie ne doivent pas être attelées. Les pompes sanitaires, pompes de ballast et de cale ou pompes d'usage général peuvent étre considérées comme pompes d'incendie. Sur tout navire. le débit des pompes affectées à la lutte contre l'incendie doit être au moins égal aux deux tiers du débit des pompes de cale exigies pour le dit navire. Chaque pompe doit être assez puissante pour fournir au minimum les deux jets énergiques dont il est question dans les présentes Règles. La portée du jet à la sortie des lances doit être d'environ 12 mètres (40 pieds).

(b) Les pompes d'incendie doivent toutes être munies de soupapes de súreté. La disposition et le réglage de ces soupapes doivent être tels, qu'ils empêchent la pression de s'élever d'une manière excessive en quelqu' endroit que ce soit du réseau principal d'incendie.

(c) Le diamètre des tuyaux doit être sufisant pour assurer un débit d'eau permettant l'utilisation simultanée d'au moins deux manches d'incendie. Il doit être calculé en fonction du débit exigé pour les pompes affectées à la lutte contre l'incendie.

(d) Le nombre et la répartition des bouches d'incendie doivent être tels. que deux jets au moins, dont l'un fourni par une manche d'une seule pièce puissent être simultanément dirigés sur un point quelconque du navire.

(e) Les tuyaux et bouches d'incendie doivent être disposés de manière que les manches puissent s'y adapter facilement. Sur les navires susceptibles de transporter des cargaisons en pontée, l'emplacement des bouches d'ineendie doit être tel que leur accès soit toujours facile, et les tuyaux doivent être. dans toute la mesure du possible, installés de manière à ne pas risquer d'être endommages par les dites cargaisons.

(f) Des robinets ou soupapes doivent être disposés sur les tuyautages, de telle manière qu'une quelconque des manches puisse être débranchée pendant que les pompes d'incendie sont en marche.

(g) Les manches d'incendie doivent être fabriquées avec des matières approuvées par l'Administration : elles doivent être d'une longueur suffisante pour permettre de diriger un jet d'eau sur l'un quelconque des points ou leur utilisation peut être rendue nécessaire. Elles doivent être pourvues des accessoires nécessaires. Le diamètre intérieur de l'ajutage de la lance ne doit pas être inférieur à $12 \mathrm{~mm}$. (un demi-pouce).

(h) Les manches prévues dans les présentes Règles comme "manches d'incendie" ainsi que les outils et accessoires nécessaires, doivent étre constamment maintenus en état de servir. Ils doivent être placés en évidence et à proximité des bouches ou prises à raccord. 


\section{Regulation 46}

Fire Extinguishers

(a) All fire extinguishers shall be of types and designs approved by the Administration. The capacity of portable extinguishers shall be not mori than 3 gallons (or $13 \frac{1}{2}$ litres) and not less than 2 gallons (or 9 litres).

(b) Spare charges shall be provided in accordance with requirements tc be specified by the Administration.

(c) Extinguishers in which the medium is stored under pressure shall not be kept in passenger or crew accommodation.

(d) Portable fire extinguishers shall be periodically examined and subjected to such tests as the Administration may require.

(e) One of the portable fire extinguishers intended for use in any space shall be stowed near the entrance to that space.

(f) The control valves for fixed extinguishing apparatus shall be so placed that they will be easily accessible and not readily cut off from use by an outbreak of tire.

\section{Regulation 47}

Fire-smorhering Gas or Steam for Cargo Spaces and Boiler Rooms

(a) Where provision is made for the injection of gas or steam into cargo spaces or boiler rooms for fire extinguishing purposes, the necessary pipes for conveying the gas or steam shall be provided with control valves or cocks which shall be readily accessible from the deck in any circumstances. and so marked as to indicate clearly the compartments to which the pipes are led. Suitable provision shall be made to prevent inadvertent admission of the gas or steam to any compartment. If any pipe is led to a space to which passengers inay have access, it shall be furnished with an additional stop valve or cock suitably protected.

(b) The piping shall be arranged so as to provide effective distribution of the fre smothering gas or steam. In large holds there shall be at least two pipes, one of which shall be fitted at the forward part and one at the after part. Where steam is used. the pipes shall be led well down into the space.

(c) (i) W'hen carbon dioxide is supplied as the extinguishing medium in cargo spaces, the quantity of gas available shall be sufficient to give a minimum volume of free gas equal to 30 per cent. of the gross volume of the largest cargo compartment in the ship which is capable of being sealed.

(ii) When carbon dioxide is supplied as an extinguishing medium for boiler rooms, the quantity of gas carried shall be sufficient to give a minimum quantity of free gas equal to 30 per cent. of the gross volume of the largest boiler room measured to the top of the boilers. If the engine and boiler rooms are not entirely separate and fuel oil can drain from the boiler room into the engine room bilges. the combined engine and boiler rooms shall be considered as one compartment.

(iii) When carbon dioxide is supplied as the extinguishing medium both for cargo spaces and for boiler rooms, the quantity of gas need not be more than that required for the largest compartment protected in this way, whether cargo compartment or boiler room.

(iv) For the purpose of this paragraph (c), the volume of gas shall be calculated at 9 cubic feet to the pound (or 0.56 cubic metres to the kilogramme). 


\section{Règle 46}

\section{Extincteurs d'lncendie}

(a) Les extincteurs d'incendie doivent être de modèles et de :aractéristiques approuvées par l'Administration. La capacité des extincteurs portatifs ne doit être ni supérieure à 13.5 litres (3 gallons) ni inférieure à 9 litres ( 2 gallons).

(b) Le nombre des charges de rechange à prévoir est fixé par l'AdminisIration.

(c) Les extincteurs contenant du gaz sous pression sont interdits dans les locaux habités servant aux passagers ou à l'équipage.

(d) Les extincteurs portatifs sont examinés périodiquement et soumis aux essais demandés par l'Administration.

(e) Un des extincteurs portatifs destinés à être employés dans un local déterminé doit être placé près de l'entrée de ce local.

$(f)$ Les robinets de mancuvre des dispositifs fixes d'extinction doivent être a facilement accessibles et placés de manière à n'être pas rendus rapidement inutilisables par un commencement d'incendie.

\section{Règle 47}

\section{Extinction par la Vapeur oul par Gaz Inerte}

(a) Quand il est fait emploi de gaz ou de vapeur comme moyen d'extinction dans les cales à marchandises ou dans les chaufferies, les tuyautages nécessaires pour amener le gaz ou la vapeur doivent être munis de soupapes ou de robinets, aisément accessibles du pont, en toutes circonstances, et sur lesquels soient clairement indiqués les compartiments desservis par chacun des tuyautages. Toutes dispositions nécessaires doivent être prises pour que du gaz ou de la vapeur ne puissent être envoyés par inadvertance dans un compartiment quelconque. Si un tuyau aboutit à un local auquel les passagers ont accès, il doit être muni d'une vanne ou d'un robinet d'arrêt supplémentaire convenablement protégé.

(b) Le tuyautage sera disposé de manière à assurer une répartition efficace du gaz extincteur ou de la vapeur. Dans les cales de grandes dimensions, seront installés au moins deux tuyaux, l'un dans la partie avant de la cale et l'autre dans la partie arrière. En cas d'emploi de vapeur, les tuyaux doivent descendre jusqu'en un point du local considéré situé suffisamment bas.

(c) (i) Quand le gaz carbonique est l'agent extincteur prévu pour les cales à marchandises, la quantité de gaz disponible doit correspondre à un volume de gaz libre au moins égal à 30 pour cent du volume brut de la plus grande des cales à marchandises susceptibles d'être isolées.

(ii) Quand le gaz carbonique est employé comme agent extincteur dans les chaufferies, la quantité de gaz amenée par le tuyautage doit être suftisante pour fournir un volume de gaz libre égal à 30 pour cent au moins du volume brut de la chaulferie la plus vaste, dimensions prises jusqu'au-dessus des chaudières. Au cas où la chambre des machines n'est pas complètement séparée de la chaufferie et où il peut se faire que du combustible liquide s'écoule de la chaufferie dans la chambre des machines, l'ensemble formé par la chaufferie et la chambre des machines doit être considéré comme formant un seul compartiment.

(iii) Quand le gaz carbonique est l'agent extincteur prévu à la fois pour les cales à marchandises et les chaufferies, il n'est pas besoin que la quantité de gaz soit supérieure à celle requise pour la protection du plus grand de ces compartiments, que celui-ci soit une cale à marchandises ou une chaufferie.

(iv) Pour l'application du présent paragraphe $(c)$, le volume occupé par le gaz sera calculé sur la base de 0.56 mètres cubes par kilog. ( 9 pieds cubes par livre). 
(d) When steam is the extinguishing medium in holds, the boiler ( boilers available for supplying steam shall have an evaporation of at lea: $1 \mathrm{lb}$. of steam per hour for each 12 cubic feet (or 1 kilogramme for eac 0.75 cubic metres) of the gross volume of the largest cargo compartmer in the ship.

(e) Means shall be provided for stopping ventilating fans from outsid the space and for closing all doorways, ventilators, annular spaces aroun, funnels and other openings to spaces in which fire smothering gas or stean may be used as a fire extinguishing medium.

( $f$ Means shall be provided for giving audible warning of the releas of carbon dioxide to any working space.

\section{Regulation 48}

\section{Auromatic Sprinkler Systems}

(a) Water sprinkler systems automatic in operation may be acceptec as satisfactory means for fire extinguishing. Where such a system is fittec it shall be kept charged at the necessary pressure and shall have provisior for a continuous supply of water.

(b) The system shall be subdivided into a number of sections to be decided by the Administration, and automatic alarms shall be provided to indicate at one or more suitable points or stations the occurrence or indication of fire, and its location.

(c) The pump or pumps to provide the discharge from sprinkler heads shall be so connected as to be brought into action automatically by a pressure drop in the system.

(d) Each pump shall be capable of maintaining a sufficient supply of water at the appropriate pressure, at the sprinkler heads, while such number of sprinkler heads as will be decided by the Administration are in operation.

(e) There shall be not less than two sources of power supply for seawater pumps, air compressors. and automatic alarns. Where the power is electrical the supply shall be taken through the emergency switchboard by a feeder reserved solely for that purpose. There shall be no switch in the circuit other than that at the switchboard. The switch shall be clearly labelled and shall normally be kept closed.

$(f)$ Sprinkler heads shall be required to operate at temperatures that will be decided by the Administration. Suitable means for the periodic testing of all automatic arrangements shall be provided.

\section{Regulation 49}

\section{Brearhing Apparatus, Smoke Helmets and Safety Lamps}

(a) A breathing apparatus or smoke helmet shall be of a type approved by the Administration.

(b) In order to avoid smoke being breathed by the wearer of a smoke helmet or mask fitted with an air bose, the length of air hose supplied shall be sufficient to reach from the open deck, well clear of hatch or doorway, to any part of the holds or machinery spaces.

(c) Safety lamps shall have a minimum burning period of three hours and be of a type approved by the Administration. 
(d) Quand la vapeur est l'agent extincteur employé dans les cales, la ou les chaudières prévues pour fournir cette vapeur doivent avoir une capacité de - production horaire d'au moins $1 \mathrm{~kg}$. de vapeur par 0,750 mètre cube (1 livre par 12 pieds cubes) de volume brut de la plus grande des cales a marchandises du navire.

(e) Des dispositifs doivent être prévus pour stopper les ventilateurs de l'extérieur du local ou ils fonctionnent et pour fermer toutes les portes. conduits de ventilation, espaces annulaires autour des cheminées et autres ouvertures des locaux où un gaz inerte ou de la vapeur peuvent être utilisés comme agents extincteurs.

(f) Un signal sonore doit permettre d'avertir de l'envoi de gaz carbonique dans tout local où du personnel peut être appelé à travailler.

\section{Règle 48}

\section{Disposirifs auromariques à Pulvérisarion d'Eau}

(a) Les dispositifs automatiques à pulvérisation d'eau peuvent être considérés comme des moyens satisfaisants pour l'extinction de l'incendie. Quand un tel dispositif est installé, il doit être main:enu chargé à la pression nécessaire et toutes mesures utiles doivent être prises pour en assurer en permanence l'alimentation en eau.

(b) L'installation doit être divisée en sections dont le nombre doit être approuvé par l'Administration et des avertisseurs automatiques doivent permettre de signaler, en un ou plusieurs points ou stations convenables, la naissance ou l'existence, ainsi que l'emplacement d'un feu.

(c) La ou les pompes, alimentant en eau les têtes des pulvérisateurs doivent être connectées de manière à assurer leur mise en marche automatique par suite de chute de pression dans l'installation.

(d) Chaque pompe doit permettre d'alimenter en eau, en quantité suff. sante et à la pression convenable pour assurer leur fonctionnement simultané. un nombre de pulvérisateurs à déterminer par l'Administration.

(e) Le nombre de sources d'énergie alimentant les pompes à eau de mer. compresseurs d'air, et avertisseurs automatiques, ne doit pas être inférieur à deux. Quand il s'agit d'énergie électrique. celle-ci doit être fournie par l'intermédiaire du tableau de secours et par une canalisation exclusivement réservée à cet usage. Le circuit ne doit comporter aucun interrupteur autre que celui du tableau de secours. Cet interrupteur doit être clairement désigné par une plaque indicatrice; il doit normalement être enfermé.

(f) La température à laquelle les pulvérisateurs doivent entrer en action sera dans chaque cas agréée par l'Administration. Toutes mesures utiles doivent être prises pour assurer la vérification, à intervalles réguliers, de tous les dispositifs automatiques.

\section{Règle 49}

\section{Appareils Respiratoires, Casques et Fanaux de Sécuriré}

(a) Tout appareil ou casque respiratoire doit être d'un modèle approuvé par l'Administration.

(b) Pour empêcher que le porteur d'un casque ou d'un masque respiratoire équipé d'un tuyau de prise d'air ne respire de la fumée. la longueur de ce tuyau devra être telle qu'elle permette d'atteindre un point quelconque des cales ou de la tranche des machines à partir d'un point situé sur le pont découvert à distance suffisante du panneau d'écoutille ou de la porte.

(c) Les fanaux de sécurité doivent avoir une capacité de marche d'au moins 3 heures; ils doivent être d'un modele approuvé par l'Administration. 


\section{Regulation 50}

\section{Requirements for Passenger Ships}

\section{Patrols and Detection}

(a) An efficient patrol system shall be maintained in all passenger ships so that any outbreak of fire may be promptly detected. Manual fire alarms are to be fitted throughout the passenger and crew accommodation to enable the fire patrol to give an alarm immediately to the bridge or fire control station.

(b) An approved fire alarm or fire-detecting system shall be provided which will automatically indicate at one or more suitable points or stations. where it can be most quickly observed by officers and crew, the presence or indication and location of fire in any part of the ship which, in the opinion of the Administration, is not accessible to the patrol system; except where it is shown to the satisfaction of the Administration that the ship is engaged on voyages of such short duration that it would be unreasonable to apply this requirement.

\section{Spaces used by Passengers and Crew}

(c) A passenger ship shall be provided with appliances whereby at least two powerful jets of water can be rapidly and simultaneously directed on any part of each deck or space used by passengers or crew when all watertight doors and all doors in the main fire-resisting bulkheads are closed. Doors in intermediate bulkheads may be provided with suitable apertures fitted with covers.

(d) A passenger ship shall be provided with such approved portable fire extinguishers as the Administration may deem to be appropriate and sufficient.

\section{Cargo Spaces}

(e) A passenger ship shall be provided with appliances whereby at least two powerful jets of water can be rapidly and simultaneously directed into any cargo space.

(f) (i) A passenger ship of 1,000 tons gross tonnage or over shall be provided with appliances whereby fire smothering gas, sufficient to give a minimum volume of free gas equal to 30 per cent. of the gross volume of the largest hold in the ship which is capable of being sealed, can be promptly conveyed by a permanent piping system into any compartment in which cargo may be carried. The Administration may allow the use of steam in lieu of smothering gas in steamships and in ships propelled by internal combustion machinery if the arrangements comply with paragraph (d) of Regulation 47.

(ii) Where it is shown to the satisfaction of an Administration that a ship is engaged on voyages of such short duration that it would be unreasonable to apply the above requirement and also in passenger ships of less than 1.000 tons gross tonnage. the arrangements in cargo spaces shall be to the satisfaction of the Administration.

\section{Machinery and Bunker Spaces}

(g) A passenger ship shall be provided with appliances whereby at least two powerful jets of water can be rapidly and simultaneously directed into any furt of the coal bunker spaces, boiler rooms and engine rooms. 
Règle 50

\section{Dispositions concernant les Navires is Passagers}

Services de ronde et détection d'incendie

(a) Un service de ronde convenable doit être organisé sur tout navire à passagers, de manière à permettre de découvrir rapidement tout commencement dincendie. Des avertisseurs à commande manuelle doivent étre installés dans tous les locaux habités à l'usage des passagers et de l'équipage, pour permettre aux rondiers de donner immédiatement l'alerte à la passerelle ou à un poste de securité.

(b) Un système approuvé d'avertisseurs d'incendie ou de détecteurs d'incendie doit être installé pour signaler automatiquement. en un ou plusieurs endroits ou postes de sicurité du navire (où les officiers et les membres de l'équipage peuvent observer avec le plus de rapidité). la présence ou l'indication. ainsi que l'emplacement, d'un incendie dans toute région du navire qui. de l'avis de l'Administration, n'est pas accessible au service de ronde, excepté quand il est démontré à la satisfaction de l'Administration que le navire effectue des voyages d'une durée si courte qu'il serait déraisonnable d'exiger cette disposition.

\section{Locaux urilisés par les Passagers ef l'Equipage}

(c) Tout navire à passagers doit être muni d'installations permetcant de diriger rapidement au moins deux jets énergiques simultanés sur tout point de chaque pont ou espace utilisé par les passagers ou par l'équipage quand les portes étanches, ainsi que toutes les portes des cloisons principales d'incendie, sont fermées. Les portes des cloisons intermédiaires peuvent être pourvues d'orifices de dimensions convenables munis d'un dispositif d'obturation.

(d) Tout navire à passagers doit être pourvu d'extincteurs d'incendie portatifs approuvés, d'un modèle approprié, et en nombre jugé suffisant par l'Administration.

\section{Locaut à Marchandises}

(e) Tout navire à passagers doit être muni d'installations permettant de diriger rapidement au moins deux jets énergiques simultanés dans l'un quelconque des locaux à marchandises.

(f) (i) Tout navire à passagers d'une jauge brute égale ou supérieure à 1,000 tonneaux doit ètre muni d'installations comportant un réseau de tuyautage permanent et permettant d'amener, dans tout compartiment susceptible d'être occupé par des marchanơises, une quantité de gaz inerte suffisante pour donner un volume de gaz libre au moins égal à 30 pour cent. du volume brut de la cale la plus vaste susceptible d'être herméliquement fermée. L'Administration intéressée pourra autoriser l'emploi de vapeur au lieu de gaz inerte sur les navires à vapeur et sur les navires mus par des moteurs à combustion interne, quand ils sont pourvus d'installations satisfaisant aux conditions requises par le paragraphe (d) de la Règle 47.

(ii) Quand il est montré à la satisfaction de l'Administration qu'un navire effectue des voyages d'une durée si courte qu'il serait déraisonnable d'exiger la disposition ci-dessus et aussi sur les navires à passagers d'une jauge brute inférieure à 1,000 tonneaux. les installations d'extinction dans les locaux à marchandises doivent étre réalisées à la satisfaction de l’Administration.

\section{Compartiment des machines ef soutes à combustible}

(g) Tout navire à passagers doit être muni d'installations pernnettant de diriger rapidement au moins deur jets énergiques simultanés sur un point quelconaue des soutes à charbon, des chaufferies et des compartiments des machines. 
(h) A passenger ship fitted with oil-fired boilers or internal combustion propelling machinery shall be provided in the machinery spaces with at least two fire hydrants, one port and one starboard, and fire hoses for each hydrant complete with couplings and conductors, together with nozzles suitable for spraying water on oil.

(i) A passenger ship in which the main or auxiliary boilers are oil fired shall comply with paragraphs $(g)$ and $(h)$ of this Regulation and with the following:-

(i) In each firing space there shall be a receptacle containing sand, sawdust impregnated with soda or other approved dry material. in such quantity as may be required by the Administration.

(ii) There shall be at least two approved portable extinguishers discharging froth or other approved medium suitable for quenching oil fires, in each fring space in each boiler room and each space in whicb a part of the oil fuel installation is situated.

(iii) There shall be approved appliances whereby froth can be rapidly discharged and distributed over the boiler room or rooms and any space in which oil fuel units or settling tanks are situated. The quantity of froth available for discharge shall be sufficient to cover to a depth of 6 inches (or 15 centimetres) the largest area over which oil fuel is liable to spread in the event of an accidental leakage. Alternatively, smothering gas or a fixed high-pressure water spraying system may be employed. If the engine and boiler rooms are not entirely separate, and fuel oil can drain from the boiler room into the engine room bilges, the combined engine and boiler rooms shall be considered as one compartment. Apparatus shall be controlled from an easily accessible position or positions. which will not be readily cut off by an outbreak of fre.

(iv) There shall be one approved froth extinguisher of at least 30 gallons (or 136 litres) capacity in the case of ships having one boiler room, and two such extinguishers in the case of ships with more than one hoiler room. These extinguishers shall be provided with hoses on reels suitable for reaching any part of the boiler rooms and spaces containing any part of the oil fuel installations. A 100 lbs. (or 45 kilogrammes) carbon dioxide extinguisher may be accepted as an alternative to a 30 gallons (or 136 litres) froth extinguisher.

(j) A passenger ship propelled by internal combustion machinery shall, in addition to complying with paragraphs $(g)$ and $(h)$ of this Regulation, be provided in each of the machinery spaces with at least one approved froth extinguisher of not less than 10 gallons (or 45 litres) capacity, and also with one approved portable froth extinguisher for each 1,000 b.h.p. of the engines or part thereof ; but the total number of portable extinguishers so supplied shall be not less than two and need not exceed six. A 35 lbs. (or 16 kilogrammes) carbon dioxide extinguisher may be accepted as an alternative to the 10 gallons (or 45 litres) froth extinguisher. 
(h) Sur tout navire à passagers équipé de chaudières à combustible liquide ou mu par des moteurs à combustion interne. on doit prévoir dans les locaux des machines au moins deux bouches d'incendie, l'une à tribord, l'autre à bâbord, et, pour chaque bouche, les manches correspondantes munies de raccords et manchons nécessaires, ainsi que les ajutages d'un modèle convenable pour projeter de l'eau en pluie sur le combustible liquide.

(i) Tout navire à passagers, sur lequel les chaudières principales ou auxiliaires sont alimentées au combustible liquide, doit satistaire aux conditions fgurant aux paragrapines $(g)$ et $(h)$ ci-dessus et répondre, en outre. aux prescriptions suivantes:

(i) Il doit y avoir. dans chaque rue de chauffe, un récipient contenant du sable. de la sciure de bois imprégnée de soude, ou toute autre matière sèche approuvée. en quantité à la satisfaction de l'Administration :

(ii) il doit y avoir, dans chaque rue de chauffe, ainsi que dans tout local renfermant une partie de l'installation relative au combustible liquide, au moins deux extincteurs portatifs distributeurs de mousse ou d'un autre agent approuvé efficace pour éteindre un incendie de combustible liquide.

(iii) des dispositifs approuvés doivent permettre de fourniret de distribuer promptement de la mousse sur le sol de la ou des chaulferies et de tout local renfermant des pompes à combustible ou des caisses de décantation. La quantité de mousse que ces appareils peuvent fournir doit être suffisante pour couvrir, sur une épaisseur de 152mm. (6 pouces), la surface la plus étendue sur laquelle il est possible que se répande du combustible liquide au cas où une fuite viendrait à se produire. Au lieu de mousse. ou peut faire usage de gaz inerte ou employer un système fixe d'extinction par projection en pluie d'eau sous forte pression. Au cas où la chambre des machines n'est pas complètement séparée de la cbaufferie et oì il peut se faire que du combustible liquide s'écoule de la chaufferie dans la chambre des machines, l'ensemble formé par la chaufferie et la chambre des machines est considéré comme formant un seul compartiment. Les appareils doivent pouvoir être commandés d'un point, ou de plusieurs points, facilement accessibles, et qui ne puissent se trouver rapidement isolés par un commencement d'incendie.

(iv) Il doit y avoir un extincteur à mousse d'un modèle approuvé et d'une capacité minima de 136 litres (30 gallons) sur les navires n'ayant qu'une chaulferie; il doit y en avoir deux sur les navires ayant plus d'une chaufferie. Ces extincteurs seront munis de manches et de dévidoirs permettant d'atteindre toute région des chaufferies et des locaux des machines où se trouve une partie quelconque de l'installation relative au combustible liquide. L'emploi d'un extincteur à gaz carbonique de $45 \mathrm{~kg}$. (100 livres) peut être admis comme équivalent à celui d'un extincteur à mousse de 136 litres (30 gallons).

(j) Sur tout navire a passagers mu par un moteur a combustion interne. en sus des dispositifs prévus aux paragraphes $(g)$ et $(h)$ ci-dessus, il doit être installé. dans chacun des compartiments des machines. au moins un extincteur à mousse d'un modèle approuvé et d'une capacité minimum de 45 litres (10 gallons). Il doit en outre être prévu, dans chacun de ces compartiments, un extincteur portatif d'un modèle approuvé par 1000 ou fraction de 1000 chevaux de puissance au frein des machines, sans que le nombre total par compartiment de ces extincteurs puisse être inférieur à deux ni qu'il puisse en être exigé plus de six par compartiment. L'emploi d'un extincteur à gaz carbonique de $16 \mathrm{~kg}$. (35 livres) peut être admis comme équivalent à un extincteur à mousse de 45 litres (10 gallons). 
(k) If in a passenger ship propelled by internal combustion machinery a donkey boiler is fitted, paragraph (i) shall be complied with. If the donkey boiler is situated in a machinery space. there shall be provided in that space. in place of the large extinguisher required by the preceding paragraph. an approved froth extinguisher of at least 30 gallons (or 136 litres) capacity fitted with suitable hose altachments or other approved means for distributing froth. A 100 lbs. (or 45 kilogrammes) carbon dioxide extinguisher may be accepted as an alternative to a 30 gallons (or 136 litres) froth extinguisher.

\section{Pumps}

(D) A passenger ship of 4.000 tons gross tonnage or over shall be provided with at least three fire pumps operated by steam or other motive power. and every passenger ship of under 4.000 tons gross tonnage, with at least two such fire pumps. Each fire pump shall be capable of delivering such quantity of water as the Administration may deem sufficient in at least two powerful jets simultaneously in any part of the ship.

(mi) In a passenger ship of 300 feet (or 91.5 metres) in length or over, fitted with oil fired boilers or internal combustion machinery. the arrangements of sea connections, pumps and sources of power for operating them shall be such as to ensure that a fire in any one compartment will not put all the tire pumps out of action. In a ship less than 300 feet (or 91.5 metres) in length, if a fire in any one compartment could put all the pumps out of action, there shall be an alternative means of extinguishing the fire.

\section{Water Service Pipes and Hydrants}

(il) A passenger ship shall be provided with water service pipes and hydrants complying with the relevant requirements of Regulation 45 .

\section{Fire Hoses}

(o) A passenger ship shall be provided with such number of fire hoses as the Administration may deem sufficient. There shall be at least one fire hose for each hydrant and these hoses shall be used only for the purpose of extinguishing fires or testing the fire-extinguishing apparatus at fire drills and survevs.

\section{Smoke Helmets and Sajety Lamps}

(p) A passenger ship shall carry at least two outfits each consisting of a breathing apparatus or smoke helmet, a safety lamp and a fireman's axe. These outfits shall be kept in widely separated places ready for use. A portable electric drilling machine to provide emergency means of access to fires through decks, casings or bulkheads. shall be available.

\section{Regulation 51}

\section{Requirements for Cargo Ships of 1,000 Tons Gross Tonnage or over}

(a) (i) A cargo ship of 2,000 tons gross tonnage or over shall be provided with apparatus whereby tire smothering gas sufficient to give a minimum volume of free gas equal to 30 per cent. of the gross volume of the largest hold in the ship which is capable of being sealed. can be promptly conveyed by a pennanent piping system into any compartment in which cargo may be 
(k) Si un navire à passalgers, muoi d'une chaudière auxiliaire, est mû par un moteur à combustion interne, il doit satisfaire aux prescriptions du paragraphe (i). Si la chaudière auxiliaire est installée dans un compartiment des machines, on doit remplacer, dans ce local, l'extincteur à mousse de 45 litres prévu au précédent paragraphe par un extincteur à mousse d'un modèle approuvé et d'une capacité minimum de 136 litres (30 gallons), muni des flexibles convenables, ou par tout autre dispositif approuvé pour la distribution de la mousse. Un extincteur à gaz carbonique de 45 kilogrammes (100 livres) peut être admis comme équivalent à un extincteur à mousse de 136 litres (30 gallons).

\section{Pompes}

(l) Tout navire à passagers d'une jauge brute égale ou supérieure à 4000 tonneaux doit être muni d'au moins trois pompes d'incendie mues par la vapeur ou par toute autre source d'énergie, et tout navire à passagers d'une jauge brute inférieure à 4000 tonneaux, d'au moins deux pompes à incendie de ce type.

Chacune de ces pompes doit être assez puissante pour débiter la quantité d'eau que l'Administration jugera utile par deux jets énergiques simultanés en un point quelconque du navire.

(m) Sur les navires à passagers d'une longueur égale ou supérieure à $91.5 \mathrm{~m}$. (300 pieds). munis de chaudières alimentées au combustible liquide ou de moteurs à combustion interne, les conduites d'eau, les pompes et les sources d'énergie qui les actionnent doivent être disposées de manière à éviter qu'un incendie dans l'un quelconque des compartiments puisse mettre toutes les pompes d'incendie hors de service.

Sur les navires d'une longueur inférieure à $91,5 \mathrm{~m}$. (300 pieds), si un incendie dans un compartiment quelconque peut rendre les pompes inutilisables, il doit y avoir à bord un autre moyen d'éteindre l'incendie.

\section{Tuyautage et bouches d'incendie}

(n) Tout navire à passagers doit être pourvu de tuyautages et de bouches d'incendie répondant aux prescriptions de la Règle 45.

\section{Manches d'incendie}

(o) Tout navire à passagers doit être pourvu de manches d'incendie en nombre suffisant à la satisfaction de l'Administration. Il doit y avoir au moins une manche par bouche d'incendie. et ces manches d'incendie ne doivent être utilisées que pour l'extinction des incendies ou pour l'essai des systèmes d'extinction lors des exercices d'incendie et des visites des installations.

\section{Casques respiratoires et fanaux de sûreté}

(p) Tout navire à passagers doit avoir à bord deux équipements au moins. composés chacun d'un casque ou appareil respiratoire. d'un fanal de sùreté et d'une hache de pompier. Ces équipements doivent être déposés en deux endroits suffisamment éloignés l'un de l'autre et maintenus en état de service. Une perceuse électrique portative. permettant en cas d'urgence de frayer un accès au lieu de l'incendie à travers ponts, tambours ou cloisons, doit être constamment disponible.

\section{Règle 51 \\ Dispositions concernant les Navires de Charge de 1000 Tomneaux de Jauge brute et au-dessus}

(a) (i) Tout navire de charge d'une jauge brute égale ou supérieure à 2,000 tonneaux doit être muni d'une installation d'extinction par gaz inerte. permettant d'envoyer, par un réseau de tuyautages fixes, dans tout cornpartiment susceptible d'être occupé par des marchandises, une quantité de gaz suffisante pour donner un volume de gaz libre au moins égal 
carried. The Administration may allow the use of steam in lieu of smothering gas in steam ships and in motor ships if the arrangements comply with paragraph (d) of Regulation 47. In tankers, froth may be accepted as a suitable alternative to smothering gas or steam.

(ii) The Administration may exempt from this requirement cargo holds of any ship (other than the tanks of a tanker)-

(a) if they are provided with steel hatch covers and effective means of closing all ventilators and other openings leading to the holds;

(b) if the ship is constructed and intended solely for carrying such cargoes as ore or coal;

(c) where it is shown to the satisfaction of the Administration that the ship is engaged on voyages of such short duration that it would be unreasonable to apply the requirement.

(b) A cargo ship of 1.000 tons gross tonnage or over shall comply with the following :-

(i) (a) There shall be two power pumps each capable of providing a full supply of water to the fire hoses together with appliances whereby at least two powerful jets of water can be rapidly and simultaneously directed into any part of the ship; such appliances to include as many fire hoses, each complete with couplings and conductor, as the Administration may deem sufficient.

(b) In such ships fitted with oil-fired boilers or internal combustion machinery, if a fire in any one compartment could put all the pumps out of action, there must be an alternative means of extinguishing the fire.

(ii) There shall be portable fire extinguishers available for immediate use in the spaces used by crew and passengers, if any. and in any case a minimum of five such extinguishers.

(iii) There shall be an outfit consisting of a breathing apparatus or smoke helmet, a safety lamp, a fireman's axe and, except in tankers, a portable electric drilling machine to provide emergency means of access to fires through decks, casings or bulkheads.

(c) A cargo ship of 1,000 tons gross tonnage or over with oil-fired boilers or internal combustion propelling machinery shall be provided in the machinery spaces with at least two fire hydrants, one port and one starboard. and for each hydrant a fire hose, complete with couplings and conductor together with a nozzle suitable for spraying water on oil.

(d) A cargo ship of 1,000 tons gross tonnage or over in which oil is used as fuel for the main or auxiljary boilers shall also comply in the boiler and machinery spaces with the following:-

(i) In each firing space there shall be a receptacle containing sand. sawdust impregnated with soda, or other approved dry material in such quantity as may be required by the Administration. 
à 30 pour cent du volume brut de la cale la plus vaste susceptible d'être hermétiquement fermée. L'Administration pourra autoriser l'emploi de vapeur au lieu de gaz inerte sur les navires à vapeur et sur les navires à moteur quand ils sont pourvus d'installations satisfaisant aux conditions requises par le paragraphe (d) de la Règle 47. Sur les bateaux-citernes, l'emploi de la mousse peut être autorisé comme un équivalent convenable du gaz inerte ou de la vapeur.

(ii) L'Auministration peut dispenser de l'observation de ces prescriptions les cales à marchandises de tous les navires (autres que les citernes des pétroliers):

(a) si les cales sont pourvues de panneaux d'écoutille en acier et de moyens efficaces de fernneture de tous les conduits d'air et autres ouvertures conduisant aux cales;

(b) si le navire est construit pour être affecté uniquement aux transports de cargaisons telles que le minerai ou le charbon;

(c) s'il est démontré à la satisfaction de l'Administration que le navire effectue des voyages de durée si courte qu'il serait déraisonnable d'exiger l'observation de ces prescriptions.

(b) Tout navire de charge d'une jauge brute égale ou supérieure à 1,000 tonneaux doit être muni:

(i) (a) de 2 pompes mues par une source d'énergie d'une puissance assurant le plein débit des manches d'incendie et d'installations permettant de diriger rapidement au moins deux jets énergiques simultanés en un point quelconque du navire. Ces installations doivent conprendre autant de manches d'incendie, comportant chacune les raccords et liexibles nécessaires, que l'Administration intéressée le jugera utile;

(b) Toutes les fois que, sur un tel navire où sont installées des chaudières à combustible liquide ou des moteurs à combustion interne, un incendie dans un compartiment quelconque peut rendre toutes les pompes inutilisables, il doit $y$ avoir à bord un autre moyen d'éteindre l'incendie.

(ii) D'extincteurs portatifs d'incendie prêts à un emploi immédiat dans tout local utilisé par l'équipage et les passagers, s il y en a. sans que ce nombre puisse jamais être inférieur à cinq;

(iii) D'un équipement composé d'un appareil ou casque respiratoire, d'un fanal de sûreté, d'une hache de pompier et, sauf sur les bateauxciternes, d'une perceuse électrique portative permettant en cas d'urgence de frayer un accès au lieu de l'incendie à travers ponts, tambours ou cloisons.

(c) Sur tout navire de charge d'une jauge brute éyale ou supérieure à 1.000 tonneaux, équipé de chaudières à combustible liquide ou de moteurs à combustion interne, il doit être prévu dans les compartiments des machines. au moins deux bouches d'incendie, l'une à tribord. l'autre à bâbord, et, pour chaque bouche d'incendie, une manche munie des raccords et inanchons nécessaires, ainsi qu'un ajutage d'un modèle convenable pour projeter de l'eau en pluie sur le combustible liquide.

(d) Sur tout navire de charge diune jauge brute égale ou supérieure à 1,000 tonneaux, sur lequel les chaudières principales ou auxiliaires sont alimentées avec un combustible liquide. les prescriptions suivantes doivent être en outre observées:

(i) il doit y avoir dans chaque rue de chauffe un récipient contenant du sable, de la sciure de bois imprégnée de soude, ou toute autre matière sèche approuvée, en quantité à la satisfaction de l'Administration. 
(ii) There sball be at least two approved portable extinguishers discbarging froth or other approved medium suitable for quenching oil fires, in each firing space in each boiler room and each space in which a part of the oil fuel installation is situated. In addition, there shall be at least one extinguisher of the same description with a capacity of 2 gallons (or 9 litres) for each burner, provided that tbe total capacity of the additional extinguisber(s) need not exceed 10 gallons (or 45 litres) for any one boiler room.

(iii) There shall be approved appliances whereby frotb can be rapidly discbarged and distributed over the boiler room and any space in whicb oil fuel units or settling tanks are situated. The quantity of froth available for discharge shall be sufficient to cover to a depth of 6 inches tbe largest area over which oil fuel is liable to spread in the event of an accidental leakage. Alternatively, smothering gas or steam or a fixed high pressure water-spraying system may be employed. If the engine and boiler rooms are not entirely separate and fuel oil can drain from the boiler room into the engine room bilges. tbe combined engine and boiler rooms shall be considered as one compartment. Apparatus shall be controlled from an easily accessible position or positions, which will not be readily cut off by an outbreak of fire.

(e) The Adnuinistration shall give special consideration to the fire extinguishing arrangements 10 be provided in the engine and boiler spaces of cargo ships of 1.000 tons gross tonnage or over in which oil and coal are used as fuel simultaneously.

(f) A cargo ship of 1,000 tons gross tonnage or over propelled by internal combustion machinery, shall be provided in the machinery spaces with-

(i) appliances in accordance with paragraph (c) of this Regulation:

(ii) one approved froth extinguisher of at least 10 gallons (or 45 litres) capacily or a $35 \mathrm{lbs}$. (or 16 kilogrammes) carbon dioxide extinguisher;

(iii) portable extinguishers in such number and so distributed as may be required by the Administration having regard to the size and lay-out of the engine room and to the borse-power of the engines, it being understood that the number of extinguishers may not be less than two and need not exceed six.

Wbere an oil-fired boiler is fitted, tbe requirements of paragrapb (d) of this Regulation are applicable.

\section{Regulation 52}

Ready Availability of Appliances

Fire extinguishing appliances in new and existing passenger ships ard cargo ships shall be kept in good order and available for immediate use at all times during the voyage. 
(ii) Il doit y avoir, dans chaque rue de chauffe, ainsi que dans tout local renfermant une partie de l'installation relative au combustible liquide, au moins deux extincteurs portatifs d'un type approuvé. distributeurs de mousse ou d'un autre agent approuvé efficace pour éteindre un incendie de combustible liquide. Il doit y avoir, en outre, au moins un extincteur répondant aux mêmes conditions, la capacité correspondante devant être de 9 litres (2 gallons) par brûleur. sans qu'on puisse toutefois exiger pour la capacité totale du ou des extincteur(s) supplémentaire(s) plus de 45 litres (10 gallons) par chaufferie.

(iii) Des dispositifs approuvés doivent permettre de produire et distribuer promptement de la mousse sur le sol de la chaufferie et de tout local qui renferme des pompes à combustible ou des caisses de décantation. La quantité de mousse que ces appareils peuvent fournir doit être sutfisante pour couvrir sur une épaisseur de $152 \mathrm{~mm}$. (6 pouces) la surface la plus étendue sur laquelle il est possible que se répande du combustible liquide au cas où une fuite viendrait à se produire. Au lieu de mousse, on peut faire usage de gaz inerte ou de vapeur, ou employer un système fixe d'extinction par projection en pluie d'eau sous forte pression. Au cas où la chambre des machines n'est pas complètement séparée de la chaufferie et où il peut se faire que du combustible liquide s'écoule de la chaufferie dans la chambre des machines. l'ensemble formé par la chaufferie et la chambre des machines est considéré comme formant un seul compartiment. Les appareils doivent pouvoir être commandés d'un point ou de plusieurs points facilement accessibles et qui ne puissent se trouver rapidement isolés par un commencement d'incendie.

(e) L'Administration devra étudier tout spécialement les dispositions d'extinction à installer dans les chaufferies et les locaux des machines des navires de charge d'une jauge brute égale ou supérieure à 1.000 tonneaux et pouvant utiliser simultanément du charbon et du combustible liquide.

(f) Sur tout navire de charge d'une jauge brute égale ou supérieure à 1000 tonneaux et mu par un moteur à combustion interne, les compartiments des machines doivent contenir :

(i) les dispositifs prévus au paragraphe (c) de la présente Règle :

(ii) un extincteur à mousse d'un modèle approuvé et d'une capacité minimum de 45 litres (10 gallons) ou un extincteur à gaz carbonique de $16 \mathrm{~kg}$. (35 livres) :

(iii) des extincteurs portatifs dont le nombre et la répartition seront fixés par l'Administration, compte tenu de la dimension et de la disposition de la chambre des machines ainsi que de la puissance des machines, étant entendu que le nombre de ces extincteurs ne peut être inférieur à deux, ni qu'on puisse en exiger plus de six.

Les prescriptions du paragraphe (d) de la présente Règle doivent être appliquées quand le navire est muni d'une chaudière à combustible liquide.

\section{Règle 52}

\section{Possibilité d'utilisation rapide des Installations}

Les installations d'extinction d'incendie des navires à passagers et des navires de charge neufs ou existants, doivent être maintenues en bon état de fonctionnement et prêtes à être immédiatement utilisées à tout moment du voyage. 


\section{Regnlation 53}

Acceptance of Substitutes

Where in this Part of this Chapter any special type of appliance, apparatus extinguishing medium or arrangement is specified, any other type of ap pliance, \&ec., may be allowed, provided the Administration is satisfied tha it is not less effective.

\section{PART F.-MISCELLANEOUS}

(Part F applies only to passenger ships)

\section{Regulation 54}

\section{Means of Escape}

(a) In and from all passenger and crew spaces, stairways and ladderways shall be arranged so as to provide a ready means of escape to the lifeboat embarkation deck. In particular the following provisions shall be complied with : -

(i) Below the bulkhead deck sufficient exit facilities shall be provided from each watertight compartment independent of watertight doors to provide adequate means of escape and shall be arranged so as to be readily accessible.

(ii) Above the bulkhead deck there shall be at least two practicable means of escape from each space bounded by main fre-resisting bulkheads, at least one of which shall give access to a stairway forming a vertical escape.

(iii) The width, number and arrangement of the stairways shall be to the satisfaction of the Administration.

(b) Practicable means of escape for the crew shall be provided from each engine room. shaft tunnel, stokehold compartment, and other working spaces, independent of watertight doors.

\section{Regulation 55 \\ Power for Going Astern}

A passenger ship shall have sulficient power for going astern to secure proper control of the ship in all normal circumstances.

\section{Regulation 56}

\section{Steering Gear}

(a) A passenger ship shall be provided, with main steering gear and auxiliary steering gear to the satisfaction of the Administration.

(b) The auxiliary apparatus shall be capable of being brought speedily into action in an emergency and shall be of adequate strength and of sufficient power to steer the ship at navigable speed. It shall be operated by power in any ship in which the Administration ivould require a rudder stock of over 9 inches (or $22 \cdot 86$ centimetres) diameter in way of the tiller.

(c) A duplicate main steering gear power unit and connections shall be acceptable as an auxiliary apparatus. 


\section{Règle 53}

Equivalences

Chaque fois qu'est prévu, dans le présent chapitre, un type déterminé d'appareil, d'agent extincteur ou d'installation, tout autre type d'appareil ou d'installation, etc., peut être autorisé pourvu que l'Administration estime qu'il n'est pas moins efficace.

\section{PARTIE F.-DIVERS}

La partie $F$ n'est applicable qu'aux navires à passagers.

\section{Règle 54}

\section{Echappées}

(a) Dans tous les locaux pour passagers et équipage, des escaliers et des échelles doivent être prévus de manière à constituer un moyen d'évacuation rapide depuis chacun des locaux jusqu'au pont des embarcations. En particulier. les dispositions suivantes doivent être observées:

(i) Sous le pont de cloisonnement, chaque compartiment étanche doit être pourvu d'échappées suffisantes, aisément accessibles et offrant une retraite qui n'exige pas la traversée de portes étanches.

(ii) Au-dessus du pont de cloisonnement, chaque local limité par les cloisons principales d'incendie doit être pourvu d'au moins deux échappées, dont l'une au moins doit accéder à un escalier formant une échappée verticale.

(iii) La largeur, le nombre et la disposition des escaliers doivent être à la satisfaction de l'Administration.

(b) Toute chambre des machines, tout tunnel d'arbre, toute chaufferie et tout autre local de service, doit être pourvu d'une échappée praticable offrant au personnel un moyen de retraite qui n'exige pas la traversée de portes étanches.

\section{Règle 55}

\section{Marche Arrière}

La puissance en marche arrière d'un navire à passagers doit être suffisante pour lui assurer des aptitudes de manœuvre convenables dans toutes les circonstances normales.

\section{Règle 56}

\section{Appareil ì gouverner}

(a) Tout navire à passagers doit être équipé d'un appareil à gouverner principal et d'un appareil à gouverner auxiliaire à la satisfaction de l'Administration.

(b) L'appareil auxiliaire doit pouvoir être mis rapidement en fonction en cas d'urgence; il doit être d'une construction assez solide et d'une puissance suffisante pour permettre de gouverner le navire à une vitesse de navigation acceptable; il doit être actionné par une source d'énergie sur tout navire pour lequel l'Administration exige une mèche de gouvernail dont le diamètre. à la hauteur de la barre, est supérieur à $228 \mathrm{~mm}$. ( 9 pouces).

(c) Un ensemble moteur et des liaisons identiques à ceux de l'appareil à gouverner principal, seront considérés comme constituant un appareil à gouverner auxiliaire. dans le sens de la présente Règle. 
CHAPTER 1II.-LIFE SAVING APPLIANCES, \&c.

\section{Regulation I}

\section{Application}

(a) This Chapter. except where it is otherwise expressly provided, applies as follows to new ships engaged on international voyages:-

Part A.-Passenger ships and cargo ships.

Part B.-Passenger ships.

Part C. - Cargo ships.

(b) In the case of existing ships engaged on international voyages and which do not already comply with the provisions of this Chapter relating to new ships, the arrangements on each ship sball be considered by the Administration with a view to securing, so far as this is practicable and reasonable. compliance with the general principles set out in Regulation 4 not later than the Ist January, 1951, and substantial compliance witb the other requirements of this Chapter.

\section{PART A.-GENERAL}

(Part A applies to both passenger ships and cargo ships)

\section{Regulation 2}

\section{Definitions}

For the purposes of this Chapter the expression "short international voyage" means an international voyage in the course of which a ship is not more than 200 miles from a port or place in which the passengers and crew could be placed in safety, and which does not exceed 600 miles in length between the last port of call in the country in which the voyage begins and the tinal port of destination.

\section{Regulation 3}

\section{Exemptions}

(a) Each Administration, if it considers that the sheltered nature and conditions of the voyage are sucb as to render the application of the full requirements of this Chapter unreasonable or unnecessary, may to that extent exempt from the requirements of this Chapter individual ships or classes of ships belonging to its country which, in the course of their voyage, do not go more than 20 miles fron the nearest land.

(b) In the case of passenger ships engaged on international voyages which are employed in the carriage of large numbers of unbertbed passengers in special trades, sucb, for example, as the pilgrim trade, the Administration. if satisfied that it is impracticable to enforce compliance with the requirements of this Chapter, may exempt such ships, when they belong to its country, from those requirements on the following conditions:-

(i) That the fullest provision which the circumstances of the trade will permit shall be made in the matter of lifeboats and orber life-saving appliances and fire protection. 


\section{CHAPITRE II.-ENGINS DE SAUVETAGE, ETC.}

\section{Règle I}

\section{Application}

(a) Le présent chapitre, sauf dans les cas où il en est autrement disposé, s'applique comme suit aux navires neufs faisant des voyages internationaux:

Partie A.-Navires à passagers et navires de charge.

Partie B.-Navires à passagers.

Partie C.-Navires de charge.

(b) Dans le cas de navires existants effectuant des voyages internationaux et ne satisfaisant pas déjà aux prescriptions du présent Chapitre relatives aux navires à passagers neufs, les mesures à prendre pour chaque navire doivent être déterminées par l'Administration de manière à obtenir autant que cela sera pratiquement possible et raisonnable, l'application au plus tard pour le ler janvier 1951 des principes généraux posés dans la Règle 4. et l'application dans une large mesure des autres prescriptions du présent Chapitre.

\section{PARTIE A.-DISPOSITIONS COMMUNES}

(La Partie A s'applique à la fois aux navires à passagers et aux navires de charge)

\section{Règle 2}

\section{Dans ce Chapitre-}

\section{Définitions}

l'expression "voyage international court" désigne un voyage international au cours duquel le navire ne s'éloigne pas de plus de 200 milles d'un port ou d'un lieu où les passagers et l'équipage puissent être mis en sécurité, et au cours duquel la distance entre le dernier port d'escale du pays où le voyage commence et le port final de destination ne dépasse pas 600 milles.

\section{Règle 3}

\section{Exemptions}

(a) Chaque Administration, si elle juge que la nature abritée et les conditions du voyage sont telies qu'elles rendraient l'application de la totalité des prescriptions du présent Chapitre ni raisonnable, ni nécessaire, peut, dans la mesure correspondante, dispenser de ces prescriptions des navires déterminés ou des catégories de navires appartenant à ce pays et qui, au cours de leur voyage, ne s'eloignent pas de plus de 20 milles de la terre la plus proche.

(b) Pour les navires à passagers effectuant des voyages internationaux, et qui sont utilisés à des transports spéciaux d'un grand nombre de passagers sans installation de couchettes, comme, par exemple, le transport de pèlerins, une Adminjstration peut, si elie juge qu'il est pratiquement impossible d'appliquer les prescriptions du présent Chapitre, dispenser ceux de ces navires qui appartiennent à ce pays des prescriptions en question, sous les conditions suivantes:-

(i) On doit appliquer, dans la plus large mesure compatible avec les circonstances du trafic, les prescriptions relatives aux enbarcations de sauvetage et aux autres engins de sauvetage ainsi qu'à la protection contre l'incendie. 
(ii) That all such boats and apparatus shall be readily available within the meaning of Regulation 4.

(iii) That a lifejacket shall be provided for every person on board.

(iv) That steps shall be taken to formulate general rules which shall be applicable to the particular circumstances of these trades. Such rules shall be formulated in concert with such other Contracting Governments, if any. as may be directly interested in the carriage of such passengers in such trades.

Notwithstanding any provisions of the present Convention the Simla Rules, 1931. shall continue in force as between the Parties to those Rules until the rules formulated under sub-paragraph (b) (iv) of this Regulation come into force.

\section{Regulation 4}

\section{Ready Availahility of Lifehoats and Buojam Apparatus}

(a) The general principles governing the provision of lifeboats and buoyant apparatus in a ship to which this Chapter applies are that they shall be readily available in case of emergeucy.

(b) To be readily available, the lifeboats and buoyant apparatus must comply with the following conditions:-

(i) They must be capable of being put into the water safely and rapidly even under unfavourable conditions of list and trim.

(ii) It must be possible to effect embarkation into the lifeboats rapidly and in good order.

(iii) The arrangement of each lifeboat and article of buoyant apparatus must be such that it will not interfere with the operation of other boats and buoyant apparatus.

(c) All life-saving appliances shall be kept in working order and availaole for immediate use before the ship leaves port and at all times during the voyage.

\section{Regulation 5}

\section{Consiruction of Lifeboats}

(a) All lifeboats must be properly constructed and shall be of such form and proportions that they shall have ample stability in a seaway, and sufficient freeboard when loaded with their full complement of persons and equipment.

(b) All lifeboats must be open boats with rigid sides having internal buoyancy only. They shall be not less than 24 feet (or $7 \cdot 3$ metres) in length, excepL where owing to the size of the ship, or for other reasons, the Administration considers the carriage of such lifeboats unreasonable or impracticable. In no ship shall the lifeboats be less than 16 feet (or 4.9 metres) in length.

(c) No lifeboat may be approved the weight of which when fully laden with persons and equipment exceeds 20 tons (or 20,300 kilogrammes).

(d) All lifeboats certified to carry more than 60 persons shall be either motor lifeboats of Class A or Class B, complying with the requirements of 
(ii) Toutes ces embarcations et tous ces engins de sauvetage doivent être rapidement disponibles dans le sens de la Règle 4.

(iii) Il doit y avoir une brassière de sauvetage pour chaque personne présente à bord.

(iv) Des dispositions doivent être prises pour formuler des prescriptions générales qui doivent s'appliquer au cas particulier de ce genre de trafic. Ces prescriptions doivent être formulées d'accord avec ceux des autres Gouvernements contractants, s'il y en a, qui peuvent être directeınent intéressés au transport de ces passagers dans ces trafics.

Nonobstant toute disposition de la présente Convention, les Règles de Simla de 1931 demeureront valables entre les Gouvernements qui y ont adbéré, jusqu'au moment où les Règles mentionnées dans l'alinéa (b) (iv) de lá présente Règle entreront en vigueur.

\section{Règle 4}

Conditions à remplir pour que les Embarcations de Sauvetage et les Engins flottants soient promptement disponibles

(a) Les principes généraux qui règlent l'armement en embarcations de sauvetage et en engins flottants d'un navire régi par le présent chapitre sont qu'ils doivent être promptement disponibles en cas d'urgence.

(b) Pour être promptement disponib!es, les embarcations de sauvetage et engins flottants doivent remplir les conditions suivantes:-

(i) On doit pouvoir les mettre à l'eau sûrement et rapidement, même dans des conditions défavorables de bande et d'assiette.

(ii) Il doit être possible d'embarquer dans les embarcations de sauvetage rapidement et en bon ordre.

(iii) L'installation de chaque embarcation de sauvetage et de chaque engin flottant doit être telle qu'elle ne gêne pas la manæuvre des autres embarcations ou engins flottants.

(c) Tous les engins de sauvetage doivent être maintenus en bon état de service et prêts à être immédiatement utilisés avant que le navire ne quitte le port et à tout moment pendant le voyage.

\section{Règle 5}

\section{Construction des Embarcations de Sauverage}

(a) Toutes les embarcations de sauvetage doivent être bien construites et avoir des formes et des proportions qui leur assurent une large stabilité à la mer et un franc-bord suffisant lorsqu'elles sont en charge avec toutes les personnes qu'elles doivent recevoir et tout leur armement.

(b) Toutes les embarcations de sauvetage doivent être des embarcations ouvertes à bordé rigide avec des flotteurs intérieurs seulement. Elles ne doivent pas avoir une longueur inférieure à $7 \mathrm{~m} .32$ (ou 24 pieds), sauf lorsqu'en raison des dimensions du navire, ou pour d'autres raisons, l'Administration considère l'emploi de telles embarcations de sauvetage comme déraisonnable ou impraticable. Sur aucun navire les embarcations de sauvetage ne doivent être d'une longueur inférieure à $4 \mathrm{~m} .88$ (ou 16 pieds).

(c) Une embarcation de sauvetage ne peut être admise si son poids en pleine charge avec les personnes qu'elle peut recevoir et son armement dépasse 20.300 kilogrammes (ou 20 tonnes anglaises).

(d) Toute embarcation de sauvetage autorisée à transporter plus de 60 personnes doit être, soit une embarcation de sauvetage à moteur de la Classe $A$ ou de la Classe $B$, répondant aux prescriptions de la Règle 9, soit 
Regulation 9 or be lifeboats fitted with other approved means of mechanical propulsion complying with the requirements of Regulation 10.

(e) All lifeboats must be of sufficient strength to enable them to be safely lowered into the water when loaded with their full complement of persons and equipment.

(f) All lifeboats must have a mean sheer at least equal to 4 per cent. of their length.

(g) In lifeboats certified to carry 100 or more persons the volume of the buoyancy shall be increased to the satisfaction of the Administration.

(h) The buoyancy of a wooden lifeboat shall be provided by watertight air-cases, the total volume of which shall be at least equal to one-tenth of the cubic capacity of the boat.

(i) The buoyancy of a metal lifeboat shall not be less than that required above for a wooden lifeboat of the same cubic capacity, the volume of watertight air-cases being increased accordingly.

(i) All thwarts and side-seats shall be fitted as low in the lifeboat as practicable, and bottom boards shall be fitted so that the thwarts shall not be more than 2 feet 9 inches (or 84 centimetres) above them.

\section{Regulation 6}

\section{Cubic Capacity of Lifeboats}

(a) The cubic capacity of a lifeboat shall be determined by Stirling's (Simpson's) Rule or by any other method giving the same degree of accuracy. The capacity of a square-sterned lifeboat shall be calculated as if the lifeboat had a pointed stem.

(b) For example, the capacity in cubic feet (or cubic metres) of a lifeboat, calculated by the aid of Stirling's Rule, may be considered as given by the following formula :-

$$
\text { Capacity }=\frac{L}{12}(4 A+2 B+4 C)
$$

$\mathrm{L}$ being the length of the lifeboat in feet (or metres) from the inside of the planking or plating at the stem to the corresponding point at the stern post; in the case of a lifeboat with a square stern, the length is measured to the inside of the transom.

A. B, C denote respectively the areas of the cross-sections at the quarterlength forward, amidships, and the quarter-length aft, which correspond to the three points obtained by dividing $\mathrm{L}$ into four equal parts (the areas corresponding to the two ends of the lifeboat are considered negligible).

The areas A, B, C shall be deemed to be given in square feet (or cross square metres) by the successive application of the following formula to each of the three cross-sections-

$$
\text { Area }=\frac{h}{12}(a+4 b+2 c+4 d+e)
$$

b being the depth measured in feet (or in metres) inside the planking or plating from the keel to the level of the gunwale, or, in certain cases, to a lower level as determined hereafter.

a. b, c, d. e denote the horizontal breadths of the lifeboat measured in feet (or in metres) at the upper and lower points of the depth and at the three points obtained by dividing $h$ into four equal parts ( $a$ and $e$ being the breadths at the extreme point. and $c$ at the middle point of $h$ ). 
une embarcation munie d'autres moyens approuvés de propulsion mécanique et répondant aux prescriptions de la Règle 10.

(e) Toute embarcation de sauvetage doit présenter une solidité suffisante pour pouvoir sans danger être mise à l'eau avec son plein chargement en personnes et en armement.

(f) Toute embarcation de sauvetage doit avoir une tonture moyenne au moins égale à 4 pour cent de sa longueur.

(g) Dans une embarcation de sauvetage autorisée à porter 100 personnes ou plus. le volume des Bottcurs doit être augmenté à la satisfaction de l'Administration.

(h) La flottabilité d'une embarcation de sauvetage en bois doit être assurée par des caissons à air étanches à l'eau. dont le volume total doit être au moins égal à un dixième de la capacité cubique de l'embarcation.

(i) La flottabilité d'une embarcation de sauvetage métallique ne doit pas être inférieure à celle qui est exigée ci-dessus pour l'embarcation en bois de même capacité cubique; le volume des caissons à air étanches doit être augmenté en conséquence.

(j) Les bancs de nage et les bancs de côté doivent être installés aussi bas que possible dans l'embarcation et les planches de fond doivent être installées de telle façon que les bancs de nage ne soient pas à plus de $84 \mathrm{~cm}$. (ou 2 pieds, 9 pouces) au-dessus d'elles.

\section{Règle 6}

\section{Capacité cubique des Embarcations de Sanverage}

(a) La capacité cubique d'une embarcation de sauvetage doit être déterminée par la Règle de Simpson (Stirling) ou par toute autre méthode donnant une précison du même ordre. La capacité d'une ernbarcation à arrière carré doit être calculée comme si l'embarcation était à arrière pointu.

(b) A titre d'indication, la capacité, en mètres cubes (ou pieds cubes) d'une embarcation de sauvetage, calculée à l'aide de la Règle de Simpson, peut être considérée comme donnée par la formule:-

$$
\text { Capacité }=\frac{L}{12}(4 A+2 B+4 C)
$$

L désignant la longueur de l'embarcation mesurée en mètres (ou pieds) à l'intérieur du bordé en bois ou tôle, de l'étrave à l'étambot: dans le cas d'une embarcation à arrière carré, la longueur doit être mesurée jusqu'à la face intérieure du tableau.

A, B, C désignent respectivement les aires des sections transversales au quart avant, milieu et au quart arrière, qui correspondent aux trois points obtenus en divisant $L$ en 4 parties égales. (Les aires correspondant aux deux extrémités de l'embarcation sont considérées comme négligeables.)

Les aires $\mathrm{A}, \mathrm{B}, \mathrm{C}$ doivent être considérées comme données en mètres carrés (ou en pieds carrés) par l'application successive, à chacune des trois sections transversales, de la formule suivante:-

$$
\text { Aire }=\frac{h}{12}(a+4 b+2 c+4 d+e)
$$

h désigne le creux mesuré en mètres (ou en pieds), à l'intérieur du bordé en bois ou tôle, depuis la quille jusquau niveau du plat-bord, ou, le cas échéant, jusqu'à un niveau inférieur déterminé comme il est dit ci-après.

$a, b, c, d$, e désignent les largeurs horizontales de l'embarcation mesurées en mètres (ou pieds) aux deux points extrêmes du creux ainsi qu'aux trois points obtenus en divisant $h$ en quatre parties égales (a et e correspondant aux deux points extrêmes et $c$ au milieu de $h$ ). 
(c) If the sheer of the gunwale, measured at the two points situated at a quarter of the length of the lifeboat from the ends, exceeds I per cent. of the length of the lifeboat, the depth employed in calculating the area of the cross-sections $A$ or $C$ shall be deemed to be the depth amidships plus 1 per cent. of the length of the lifeboat.

(d) If the depth of the lifeboat amidships exceeds 45 per cent. of the breadth, the depth employed in calculating the area of the amidship crosssection B shall be deemed to be equal to 45 per cent. of the breadth, and the depth employed in calculating the areas of the quarter-length sections $A$ and $C$ is obtained by increasing this last figure by an amount equal to 1 per cent. of the length of the lifeboat, provided that in no case shall the depths employed in the calculation exceed the actual depths at these points.

(c) If the depth of the lifeboat is greater than 4 feet (or 122 centimetres) the number of persons given by the application of this rule shall be reduced in proportion to the ratio of 4 feet (or 122 centimetres) to the actual depth, until the lifeboat has been satisfactorily tested afloat with that number of persons on board, all wearing life-jackets.

(f) Each Administration shall impose, by suitable formula, a limit for the number of persons allowed in lifeboats with very fine ends and in lifeboats very full in form.

(g) Each Administration may assign to a lifeboat, capacity equal to the product of the length. the breadth and the depth multiplied by 0.6 if it is evident that this formula does not give a greater capacity than that obtained by the above method. The dimensions shall then be measured in the following manner:-

Length.-From the intersection of the outside of the planking with the stem to the corresponding point at the stern post or, in the case of a square-sterned boat, to the after side of the transom.

Breadth.-From the outside of the planking at the point where the breadth of the boat is greatest.

Depth.-Amidships inside the planking from the keel to the level of the gunwale. but the depth used in calculating the cubic capacity may not in any case exceed 45 per cent. of the breadth.

In all cases the shipowner has the right to require that the cubic capacity of the lifeboat shall be determined by exact measurement.

(h) The cubic capacity of a motor boat is obtained from the gross capacity by deducting a volume equal to that occupied by the motor and its accessories, and, when carried, the radiotelegraph installation and the searchlight with their accessories.

\section{Regulation 7}

\section{Carrying Capacity of Lifeboats}

(a) The number of persons which a lifeboat can accommodate is equal to the greatest whole number obtained by dividing the capacity in cubic feet by 10 (or in cubic metres by 0.283 ).

(b) This number shall be reduced when it is greater than the number of persons for which there is proper seating accommodation; the latter number shall be determined in such a way that the persons when seated do not interfere in any way with the use of the oars.

(c) In the test for determining the number of persons which a lifeboat can accommodate each person shall be assumed to be an adult person wearing a lifejacket. 
(c) Si la tonture du plat-bord, mesurée en deux points situés au quart de la longueur à partir des extrémités, dépasse un centième de la longueur de l'embarcation, le creux à employer pour le calcul de la surface de la section transversale $\mathrm{A}$ ou $\mathrm{C}$ doit être pris égal au creux au milieu, augmenté du centième de la longueur de l'embarcation.

(d) $\mathrm{Si}$ le creux de l'embarcation de sauvetage au milieu dépasse les 45 centièmes de la largeur, le creux à employer pour le calcul de la surface de la section transversale milieu B doit être pris égal aux 45 centièmes de la largeur et les creux à employer pour le calcul des surfaces des sections transversales $A$ et $C$ situées aux quarts avant et arrière s'en déduisent en augmentant le creux employé pour le calcul de la section B d'un centième de la longueur de l'embarcation. sans pouvoir dépasser toutefois les creux réels en ces points.

(e) Si le creux de l'embarcation de sauvetage est supérieur à 122 centimètres ( 4 pieds) le nombre de personnes que l'application des rígles conduit à admettre doit être réduit dans la proportion de cette limite au creux réel. jusqu'à ce qu'une expérience à flot avec à bord ledit nombre de personnes. toutes munies de leurs brassières de sauvetage, ait permis d'arrêter définitivement ce nombre.

(f) Chaque Administration doit fixer par des formules convenables une limitation du nombre des personnes dans les embarcations de sauvctage à extrémités très fines et dans celles qui présentent des formes très pleines.

(g) Chaque Administration peut attribuer à une embarcation de sauvetage une capacité égale au produit par 0,6 des trois dimensions, s'il est reconnu que ce mode de calcul ne donne pas un résultat approché par excès: les dimensions s'entendent alors mesurées dans les conditions suivantes:

Longueur: hors bordé, entre intersections de celui-ci avec l'étrave et l'étambot: dans le cas d'une embarcation à arrière carré, jusqu'a la facc extérieure du tableau;

Largeur : hors bordé, au fort de la section milieu;

Creux : au milieu, à l'intérieur du bordé, depuis la quille jusqu'au niveau du plat-bord. Mais le creux à faire intervenir dans le calcul de la capacité cubique ne peut, en aucun cas, dépasser les 45 centièmes de la largeur.

Dans tous les cas, l'armateur est en droit d'exiger que le cubage de l'embarcation soit effectué exactement.

(h) La capacité cubique d'une embarcation de sauvetage à moteur se déduit de la capacité brute en retranchant de celle-ci un volume égal à celui qui est occupé par le moteur et ses accessoires, et, le cas échéant. par l'installation radiotélégraphique et le projecteur avec leurs accessoires.

\section{Règle 7 \\ Capacité de Transport des Embarcations de Sauvetage}

(a) Le nombre de personnes qu'une embarcation de sauvetage est appelée à recevoir est égal au plus grand nombrc entier obtenu en divisant sa capacité en mètres cubes par 0,283, ou sa capacité en pieds cubes par 10 .

(b) Ce nombre doit être réduit quand il est plus grand que le nombre de personnes pour lesquelles des places assises ont été prévues. Ce dernier nombre doit être déterminé de telle façon que les personnes, une fois assises, ne gênent en aucune façon l'usage des avirons.

(c) Dans l'essai pour la détermination du nombre de personnes qu'une embarcation est apte à recevoir, il doit être supposé que chacune des personnes est une personne adulte, portant une brassière de sauvetage. 


\section{Regulation 8}

Proportion of Motor Lifeboats and Other Mechanically Propelled Lifeboats to be Carried

(a) Where the number of lifeboats required to be carried in a ship is 20 or more. two shall be motor lifeboats of Class A complying with the requirements of Regulation 9.

(b) Where the number of lifeboats to be carried in a ship is more than 13 but less than 20, one shall be a motor lifeboat of Class $A$ and a second shall be a motor lifeboat of Class A or Class B complying with the requirements of Regulation 9 or an approved mechanically propelled lifeboat com. plying with the requirements of Regulation 10.

(c) All passenger ships not provided under the foregoing provisions with a motor lifeboat shall carry a motor lifeboat of either Class A or Class B, complying with the requirements of Regulation 9 or an approved mechanically propelled lifeboat complying with the requirements of Regulation 10.

(d) All cargo ships of 1,600 tons gross tonnage and upwards shall carry a motor lifeboat of Class A or Class B complying with the requirements of Regulation 9 or a mechanically propelled lifeboat complying with the requirements of Regulation 10.

\section{Regulation 9 \\ Specification of Motor Lifeboat}

(a) Class A

A motor lifeboat of Class A shall comply with the following conditions:-

(i) It shall be fitted with an approved type of compression ignition engine and be provided with fuel sufficient for 24 hours continuous operation, and kept so as to be at all times ready for use.

(ii) The engine and its accessories shall be suitably enclosed to ensure operation under adverse weather conditions, and provision shall be made for going astern.

(iii) The speed ahead shall be at least six knots in smooth water when loaded with its full complement of persons and equipment.

(b) Class B

A motor lifeboat of Class B shall comply with the following conditions:-

(i) It shall be adequately provided with fuel, and kept so as to be at all times ready for use.

(ii) The engine and its accessories shall be suitably enclosed to ensure operation under adverse weather conditions, and provision shall be made for going astern.

(iii) The speed ahead shall be at least four knots in smooth water when loaded with its full complement of persons and equipment. 


\section{Règle 8}

Nombre réglemensaire des Embarcasions de Sauverage à moseur ou à propulsion mécanigue

(a) Quand le nombre des embarcations de sauvetage qu'il est prescrit d'avoir à bord d'un navire à passagers est 20 ou plus, deux d'entre elles doivent étre des embarcations à moteur de la classe $A$, satisfaisant aux prescriptions de la Règle 9.

(b) Quand le nombre d'embarcations de sauvetage qu'il est prescrit d'avoir à bord d'un navire à passagers est supérieur à 13 , mais inférieur à 20 , une des embarcations de sauvetage doit être une embarcation de sauvetage à moteur de la classe $A$ et une seconde doit être une embarcation de sauvetage à moteur de la classe $A$ ou de la classe $B$, satisfaisant dans les deux cas aux prescriptions de la Règle 9. ou une embarcation de sauvetage à propulsion mécanique d'un type approuvé satisfaisant aux prescriptions de la Règle 10.

(c) Tous les navires à passagers qui ne sont pas équipés d'embarcations de sauvetage à moteur, conformément aux prescriptions ci-dessus, doivent être équipés d'une embarcation de sauvetage de la Classe $A$ ou $B$, satisfaisant aux prescriprions de la Règle 9, ou d'une embarcation de sauvetage à propulsion mécanique d'un type approuvé satisfaisant aux prescriptions de la Règle 10.

(d) Tous les navires de charge de 1600 tonneaux de jauge brute et au-dessus doivent avoir à bord, soit une embarcation de sauvetage à moteur de la classe A ou B, satisfaisant aux prescriptions de la Règle 9, soit une embarcation de sauvetage à propulsion mécanique satisfaisant aux prescriptions de la Règle 10.

\section{Règle 9}

\section{Spécification des Embarcasions de Salverage à moteur}

\section{(a) Classe A}

Une embarcation de sauvetage à moteur de la classe $\mathrm{A}$ doit remplir les conditions suivantes:-

(i) Elle doit être équipée avec un type approuvé de moteur à combustion interne; elle doit porter un approvisionnement de combustible suffisant pour 24 heures de marche continue et être maintenue constamment en état de marche.

(ii) Le moteur et ses accessoires doivent être convenablement enfermés, pour en assurer le fonctionnement dans des conditions de temps défavorables; des dispositions doivent être prises pour assurer la marche arrière.

(iii) La vitesse en marche avant doit être d'au moins 6 nœuds, en eau calme, avec son chargement complet en personnes, en combustible et en armement.

(b) Classe B

Une embarcation de sauvetage à moteur de la classe B doit remplir les conditions suivantes:-

(i) Elle doit porter un approvisionnement convenable de combustible et être maintenue constamment en état de marche.

(ii) Le moteur et ses accessoires doivent être convenablement enfermés afin d'en assurer le fonctionnement dans des conditions de temps défavorables, et des dispositions doivent être prises pour assurer la marche arrière.

(iii) La vitesse en marche avant doit être d'au moins 4 nauds en eau calme avec un chargement complet de personnes. de combustible et de son armement. 
(c) The volume of the internal buoyancy appliances of a motor lifeboat shall be at least equal to that of the buoyancy appliances which would be required under these Regulations if the boat were not a motor lifeboat, and shall be increased above that volume, if, and to the extent that such increase is necessary to compensate for the difference between-

(i) the wcight of the engine and its accessories, and, if fitted, the searchlight and the radiotelegraph installation and their accessories. and

(ii) the weight of the additional persons which the lifeboat could accommodate if the motor and its accessories, and, if litted, the searchlight and the radiotelegraph installation and their accessories, were rcmoved.

(d) Where a Class A motor lifeboat is carried voluntarily in place of a Class B motor lifeboat, or other type of approved niechanically propelled lifeboat. in excess of the numbers required, the requirements of paragraph (b) (i) of this Regulation in regard to fuel shall apply.

\section{Regulation 10}

Specification of a Mechanically Propelled Lifeboat other than a Motor Lifeboat

A mechanically propelled lifeboat, other than a motor lifeboat, shall comply with the following conditions:-

(a) The propelling gear shall be of an approved type and shall bave sufficient power to enable the lifeboat to be readily cleared from the ship's side when launched and to be able to hold course under adverse weather conditions. If the gear is manually operated it shall be capable of being worked by persons untrained in its use and shall be capable of being operated when the lifeboat is flooded.

(b) Provision shall be made for going astern.

(c) The volume of the internal buoyancy of a mechanically propelled lifeboat, other than a motor lifeboat. shall be increased to compensate for the weight of the propelling gear.

\section{Regulation 11}

\section{Equipment of Lifeboats}

(a) The normal equipment of every lifeboat shall consist of :-

(i) a single banked complement of oars, two spare oars, and a steering oar: one set and a half of thole pins or crutches, attached to the lifeboat by lanyard or chain; a boat hook;

(ii) two plugs for each plug bole (plugs are not required when proper automatic valves are fitted) attached to the lifeboat by lanyards or chains; a baler, and two buckets of approved material;

(iii) a rudder attached to the lifeboat and a tiller;

(iv) two hatchets, one at each end of the lifeboat:

(v) a lamp, with oil sufficient for 12 hours: two boxes of suitable matches in a water-tight container: 
(c) Le volume des tlotteurs intérieurs d'une embarcation de sauvetage à moteur doit être au moins égal à celui des flotteurs qui seraient prescrits d'après les présentes règles si l'embarcation n'était pas une embarcation de sauvetage à moteur, et il doit être augmenté s'il y a lieu et dans la mesure nécessaire pour compenser la différence entre:

(i) le poids du moteur, de ses accessoires, et, le cas échéant, du projecteur. de l'installation radiotélégraphique et de leurs accessoires; et

(ii) le poids de personnes supplémentaires que l'embarcation de sauvetage pourrait recevoir. si le moteur, ses accessoires, et, le cas échéant, le projecteur, l'installation radiotélégraphique et leurs accessoires étaient enlevés.

(d) Lorsqu'une embarcation de sauvelage à moteur de la classe $A$ est mise à bord, volontairement, au lieu d'une embarcation de sauvetage à moteur de la classe B ou d'un autre type d'embarcation de sauvetage à propulsion mécanique d'un type approuvé, en plus du nombre requis, les stipulations du paragraphe (b) (i) de la présente Règle doivent être appliquées en ce qui concerne le combustible.

\section{Règle 10}

Spécificasion des Embarcations de sauverage à propulsion mécanique aurres que les Embarcasions de Sauverage à moreur

Une embarcation de sauvetage à propulsion mécanique qui n'est pas à moteur, doit satisfaire aux conditions suivantes:

(a) Le dispositif de propulsion doit ètre d'un type approuvi et doit avoir une puissance suffisante pour permettre à l'embarcation de sauvetage de s'éloigner promptement du navire lors de la mise à l'eau, ainsi que de maintenir la direction de la marche dans des conditions de temps défavorables. Si le dispositif de propulsion a une commande à main, il doit être tel qu'il puisse être manœuvrable par des personnes inexpérimentées, et il doit également pouvoir être manœuvré quand l'embarcation de sauvetage est pleine d'eau.

(b) Des dispositions seront prises pour la marche arrière.

(c) Le volume des flotteurs intérieurs d'une embarcation de sauvetage à propulsion mécanique, autre qu'une embarcation de sauvetage à moteur, doit être augmenté pour compenser le poids du dispositif de propulsion.

\section{Règle 11}

\section{Armement des Embarcarions de Sauverage}

(a) L'armement normal de chaque embarcation de sauvetage sera le suivant: -

(i) Un nombre suffisant d'avirons pour la nage en pointe, plus deux avirons de rechange, et un aviron de queue: un jeu et demi de dames de nage ou de tolets, attachés à l'embarcation par une aiguillette ou chaine; une gaffe;

(ii) Deux lampons pour chaque nable (il n'est pas exigé de lampons pour les nables munis de soupapes automatiques convenables). attachés à l'embarcation par des aiguillettes ou chaines; une écope et deux seaux faits d'une matière approuvée;

(iii) Un gouvernail attaché à l'embarcation par une aiguillette, et une barre franche:

(iv) Deux hachettes, une à chaque bout de l'embarcation:

(v) Un fanal avec de l'huile pour 12 heures d'éclairage, deux boîtes d'allumettes appropriées dans un récipient étanche à l'eau; 
(vi) a mast or masts, with galvanised wire stays together with sails (coloured orange);

(vii) an efficient compass in binnacle, to be luminised or fitted with suitable means of illumination;

(viii) a life-line becketed round the outside of the lifeboat;

(ix) a sea-anchor of approved size;

(x) two painters of sufficient length. One shall be secured to the forward end of the lifeboat with sirop and toggle so that it can be released. and the other shall be firmly secured to the stem of the lifeboat and be ready for use;

(xi) a vessel containing one gallon (or four and balf litres) of vegetable, fish or animal oil. The vessel shall be so constructed that the oil can be easily distributed on the water, and so arranged that it can be attached to the sea-anchor;

(xii) an air-tight receptacle containing two pounds (or one kilogramme) of provisions for each person:

(xiii) one pound (or half a kilogramme) of condensed milk or its equivalent for each person;

(xiv) water-tight receptacles containing three quarts (or three litres) of fresh water for each person; a dipper with lanyard;

(xv) two parachute signals of approved type capable of giving a brigbt red light at a high altitude; six hand flares of an approved type giving a bright red light;

(xvi) two buoyant smoke signals of an approved type (for day-time use) capable of giving otf a volume of orange-coloured smoke;

(xvii) approved means to enable persons to cling to the boat should it be upturned, in the form of bilge keels or keel rails, together with grab lines secured from gunwale to gunwale under the keel, or other approved arrangements;

(xviii) an approved first aid outfit in a watertight case.

(xix) an electric torch suitable for morse-signalling together with two spare batteries and two spare bulbs:

(xx) a dayligbt-signalling mirror of an approved type:

(xxi) a jack-knife fitted with a tin opener to be kept attached to the boat with a lanyard;

(xxii) two light buoyant heaving lines;

(xxiii) a manual pump of an approved type; and

(xxiv) a suitable locker for stowage of small items of equipment.

(b) In the case of ships engaged on voyages of such duration that in the opinion of the Administration concerned the items specified in subparagraphs (vi), (xii), (xiii), (xx) and (xxi) of paragraph (a) of this Regulation are unnecessary, the Administration may allow them to be dispensed with.

(c) Notwithstanding the provisions of paragraph (a) of this Regulation. motor lifeboats or other approved mechanically propelled lifeboats need not carry a mast or sails or more than half the complement of oars, but they shall carry two boat hooks.

(d) All lifeboats certified to carry more than 60 persons shall be fitted with suitable means to enable persons in the water to climb into the lifeboat. 
(vi) Un màt, ou des màts, avec des étais en fil d'acier galvanisé et des voiles de couleur orange;

(vii) Un compas efficace enfermé dans un habitacle qui sera lumineux ou muni de moyens convenables d'iclairage;

(viii) Une flière en guirlande extérieure à l'cmbarcation;

(ix) Une ancre flottante de dimension approuvée;

(x) Deux bosses de longueur sulfisante: une d'elles sera tenue à l'extrême avant au moyen d'une estrope et d'un cabillot de manière à ce qu'elle puisse étre larguẻe, et l'autre sera frappée solidement à l'étrave et prête à servir;

(xi) Un récipient contenant quatre litres et demi (ou un gallon anglais) d'huile végétale, de poisson, ou animale; le récipient doit être disposé de façon à permettre de répandre aisément l'huile sur l'eau et construit de manière à pouvoir être amarré à l'ancre flottante;

(xii) Un récipient étanche à l'air contenant des vivres à raison de deux livres anglaises (906 grs.) de vivres par personne;

(xiii) Une livre anglaise ( 453 grammes) de lait condensé par personne, ou son équivalent;

(xiv) Un réceptacle étanche à l'eau contenant trois quarts anglais (équivalent à trois litres) d'eau douce par personne; un gobelet fixé par une aiguillette;

(xv) Deux signaux parachutes d'un type approuvé, capables de produire une lumière rouge brillante à une haute altitude; six feux à main d'un type approuvé donnant une lumière rouge brillante;

(xvi) Deux signaux fumigènes flottants d'un type approuvé (pour emploi durant le jour) capables de produire une quantité de fumée de couleur orange:

(xvii) Des dispositifs d'un type approıvé, permettant aux personnes de s'accrocher à l'embarcation si elle se retourne, sous la forme de quilles de roulis, de tringles, de quilles, ainsi que des filières de platbord à plat-bord en passant sous la quille de l'embarcation, ou tout autre dispositif approuve;

(xviii) Un coffre étanche de médicaments de première urgence, d'un type approuvé:

(xix) Une lampe électrique capable d'être utilisée pour des signaux morses; deux batteries de réserve, deux ampoules de reserve:

(xx) Un miroir de signalisation d'un type approuvé pour être utilisé durant le jour:

(xxi) Un couteau de poche avec un ouvre-boite attaché à l'embarcation par une aiguillette;

(xxii) Deux halins légers flottants;

(xxiii) Une pompe à main d'un type approuvé:

(xxiv) Un coffre convenable pour recevoir le petit-matériel d'armement.

(b) Dans le cas de navires effectuant des voyages d'une durée telle que dans l'opinion de l'Administration intéressée. les articles spécifiés dans les alinéas (vi). (xii), (xiii), (xx), ( $x x i)$ du paragraphe (a) de la présente Règle sont considérés commc superflus, l'Administration peut en permettre la dispense.

(c) Malgré les dispositions du paragraphe $(a)$ de la présente Règle, les embarcations de sauvetage à moteur ou toutes autres embarcations de sauvetage à propulsion mécanique d'un type approuvé ne sont pas tenucs de porter au mât ou des voiles, ou plus de la moitié de l'armement en avirons. mais elles doivent porter deux gaffes.

(d) Toutes les embarcations de sauvetage admises à transporter plus de 60 personnes doivent être munies de dispositifs convenables pour permettrc à une personne se trouvant dans l'eau de se hisser dans l'embarcation de sauvctage. 


\section{Regulation 12 \\ Security of Lifeboas Equipment}

All items of lifeboat equipment not kept in the lockers, with the exception of the boat hook which shall be kept free for fending off purposes, shall be suitably secured within the lifeboat. The lashing shall be earried out in such a manner as to ensure the security of the equipment and so as not to interfere with the lifting hooks or to prevent ready loading of, or impede ready entry into, the lifeboat.

\section{Regulation 13}

\section{Lifebuas Porrable Radio Apparatus}

(a) Ships carrying less than 20 lifeboats shall be provided with an approved portable radiotelegraph apparatus complying with the requirements set out in Regulation 14 of Chapter IV. All this equipment shall be kept together in the chart room or other suitable place ready to be moved to one or other of the lifeboats in the event of an emergency.

(b) In the case of ships engaged on voyages of such duration that, in the opinion of the Administration. lifeboat portable radio apparatus is unnecessary, the Administration may allow such equipment to be dispensed with.

\section{Regulation 14}

\section{Embarkation into the Lifeboass}

Suitable arrangements shall be made for embarkation into the lifeboats, which shall include:-

(a) a suitable ladder at each set of davits, to afford access to the lifeboats when waterborne;

(b) suitable means for illuminating the launching gear and lifeboats during the process of launching:

(c) suitable arrangements for warning the passengers and crew that the ship is about to be abandoned. and

(d) suitable means situated outside the engine room whereby any discharge of water into the lifehoats can be prevented.

\section{Regulation 15}

\section{Marking of Lifeboats and Buoyant Apparasus}

(a) The dimensions of a lifeboat and the number of persons which it is authorised to carry shall be marked on it in clear permanent characters. The name of the ship to which the lifeboat belongs shall be painted on the bows.

(b) Buoyant apparatus (and life rafts carried in lieu of buoyant apparatus) shall be marked with the number of persons in the same manner.

(c) No lifeboat or buoyant apparatus shall be marked for a greater number of persons than that obtained in the manner specified in these Regulations. 


\section{Règle 12}

\section{Maintien en bon ordre de l'Armement des Embarcations de Sauvetage}

Tout le matériel d'armement des embarcations de sauvetage qui n'est pas enfermé dans des caissons, doit être convenablement saisi dans l'embarcation, à l'exception de la gaffe qui sera gardée claire pour déborder l'embarcation. Les saisines doivent être disposées de manière à assurer le maintien du matériel, sans engager les crocs de hissage, ni empêcher le rapide chargement ou l'accès immédiat dans les embarcations.

\section{Règle 13}

\section{Appareil porlatif de Radio pour Embarcation de Sauletage}

(a) Les navires ayant moins de 20 embarcations doivent être mnunis d'un appareil portatif de radio d'un type approuvé et satisfaisant aux prescriptions de la Règle 14 du Chapitre IV. Tout cet équipement doit être conservé dans la chambre des cartes ou dans tout autre lieu convenable, et prêt à être transporté dans n'importe laquelle des embarcations en cas d'urgence.

(b) Dans le cas de navires effectuant des voyages d'une durée telle que, dans l'opinion de l'Administration, un appareil portatif de radio serait superflu. l'Administration peut en accorder la dispense.

\section{Règle 14}

\section{Accès aux Embarcations}

Des dispositions convenables doivent être prises pour permettre l'accès aux embarcations.

Ces dispositions comprennent:

(a) une échelle appropriée, correspondant à chaque jeu de bossoirs, pour permettre l'accès aux embarcations lorsqu'elles sont à l'eau;

(b) des dispositifs appropriés pour éclairer les appareils de unise à l'eau et les embarcations, lors de la mise à l'eau;

(c) des dispositions appropriées pour avertir les passagers et l'équipage que le navire est sur le point d'être abandonné; et

(d) des dispositifs appropriés situés en dehors de la chambre des machines, permettant d'arrêter toute décharge d'eau dans les embarcations.

\section{Règle 15}

\section{Inscriptions sur les Embarcations de Sauvetage et les Engins flottants}

(a) Les dimensions de l'embarcation de sauvetage, ainsi que le nombre de personnes qu'elle est autorisée à recevoir, doivent être inscrits sur l'embarcation de sauvetage en caractères indélébiles et faciles à lire. Le nom du navire auquel l'embarcation de sauvetage appartient doit être peint sur l'avant et les deux bords.

(b) On inscrira de la même manière le nombre de personnes sur les engins Gottants (et les radeaux transportes au lieu des engins flottants).

(c) On ne doit pas inscrire sur une embarcation de sauvetage ou sur un engin flottant un nombre de personnes plus grand que celui qui est obtenu en application des présentes Règles. 


\section{Regulation 16}

Specification of a Lifebuoy

(a) A lifebuoy shall satisfy the following requirements:-

(i) It shall be of solid cork or any other equivalent material:

(ii) It shall be capable of supporting in fresh water for 24 hours at least 32 pounds (or 14.5 kilogrammes) of iron.

Lifebuoys filled with rushes, cork shavings or granulated cork, or any other loose granulated material, or whose buoyancy depends upon air compartments which require to be inflated, are prohibited.

(b) Lifebuoys shall be fitted with beckets securely seized. At least one lifebuoy on each side shall be fitted with a life-line of at least 15 fathoms (or 27.5 metres) in length. Not less than one-half of the total number of lifebuoys, and in no case less than six shall be provided with efficient self-igniting lights which cannot be extinguished by water, and these shall be kept near the buoys to which they belong. with the necessary means of attachment.

(c) All lifebuoys shall be so placed as to be readily accessible to the persons on hoard.

(d) Lifebuoys shall always be capable of being rapidly cast loose and shall not be permanently secured in any way.

\section{Regulation 17}

\section{Lifejackets}

(a) Ships shall carry for every person on board a lifejacket of a type approved by the Administration, and in addition, unless these lifejackets can be adapted for use by children, a sufficient number of lifejackets suitable for children.

(b) A lifejacket shall not be approved by an Administration unless it satisfies the following requirements:-

(i) It shall be constructed with proper workmanship and materials,

(ii) It shall be capable of supporting in fresh water for 24 hours 16.5 pounds (or 7.5 kilogrammes) of iron.

(iii) It shall be reversible.

(iv) It shall be capable of holding up the head of an unconscious person in the water.

Lifejackets, the buoyancy of which depends on air compartments, are prohibited.

(c) Lifejackets shall be so placed as to be readily accessible and their position shal! be plainly indicated.

\section{Regulation 18}

\section{Line-Throwing Appliances}

(a) Ships shall carry a line-throwing appliance of a type approved by the Administration.

(b) The appliance shall be capable of carrying a line not less than 250 yards (or 230 metres) with reasonable accuracy, and shall include not less than four projectiles and four lines. 


\section{Règle 16}

Caractéristique des Bouées de Sauveluge

(a) Une bouée de sauvetage doit remplir les conditions suivantes :

(i) ètre soit en liège massif, soit en toute autre matière équivalente;

(ii) être capable de soutenir, en eau douce, pendant 24 beures un poids de fer d'au moins $14 \mathrm{kgs} .5$ (32 livres anglaises);

Sont prohibées les bouées de sauvetage dont le remplissage est constitué par du jonc, du liège en copeaux ou en grains, ou par toute autre substance à l'état de déchets et sans cohésion propre ainsi que les bouées dont la flottabilité est assurée au moyen de compartiments à air nécessitant une insufflation préalable.

(b) Les bouées doivent être pourvues de guirlandes solidement amarrées. Il doit y avoir une bouée au moins, de chaque bord, qui soit pourvue d'une ligne de sauvetage longue de $27 \mathrm{~m}, 50$ (ou 15 brasses) au moins. Le nombre des bouées de sauvetage lumineuses ne doit pas être inférieur à la moitié du nombre total des bouées de sauvetage et ne doit en aucun cas Jescendre au-dessous de six. Les appareils lumineux correspondants doivent être automatiques, efficaces et ne doivent pas s'éteindre par l'effet de l'eau; ils doivent être disposés au voisinage de leurs bouées avec les organes de fixation nécessaires.

(c) Toutes les bouées de sauvetage doivent être installées à bord de façon à être à portée immédiate des personnes embarquées.

(d) Les bouées de sauvetage doivent pouvoir toujours être larguées instantanément et ne comporter aucun dispositif de fixation permanente.

\section{Règle 17}

\section{Brassières de Sawierage}

(a) Les navires doivent avoir, pour chaque personne présente à bord, une brassière de sauvetage d'un type approuvé par l'Administration, et, en outre, un nombre convenable de brassières spéciales pour enfants, à moins que les brassières précédentes ne puissent être ajustables à la taille des enfants.

(b) Une brassière de sauvetage ne doit pas être approuvée par l'Administration à moins de remplir les conditions suivantes:-

(i) être de matière et de construction appropriées;

(ii) être capable de soutenir en eau douce pendant 24 heures un poids de fer de $7 \mathrm{kgs}$. 5 (ou $16 \frac{1}{2}$ livres anglaises);

(iii) être reversible:

(iv) être capable de soutenir la tête d'une personne évanouie se trouvant dans l'eau.

Sont prohibées les brassières dont la flottabilité est assurée au moyen de compartiments à air.

(c) Les brassières doivent être installées à bord de manière à être rapidement accessibles; leur position doit être clairement indiquée.

\section{Règle 18}

\section{Appareil Lance-amarre}

(a) Tout navire doit être muni d'un appareil lance-amarre d'un type approuvé par l'Administration.

(b) Cet appareil doit être capable de lancer avec une précision suffisante une ligne à une distance d'au moins 230 mètres (ou 250 yards) et doit comprendre au moins 4 fusćes et 4 lignes. 


\section{Regulation 19}

\section{Ships' Distress Signals}

Ships shall be provided, to the satisfaction of the Administration, with means of making effective distress signals by day and by nigbt, including parachute signals capable of giving a bright red light at a high altitude.

\section{Regulation 20}

\section{Muster Lisi and Emergency Procedure}

(a) Special duties to be undertaken in the event of an emergency shall be allotted to each member of the crew.

(b) The muster list shall show all these special duties and shall indicate. in particular, the station to which each member must go, and the duties that he has to perform.

(c) Before the vessel sails, the muster list shall be drawn up. Copies shall be posted in several parts of the ship, and in particular in the crew's quarters.

(d) The muster list shall assign duties to the different members of the crew in connection with:-

(i) the closing of the watertight doors. valves and closing mechanisms of scuppers, ash shoots, \&c.;

(ii) the equipping of the lifeboats, including the portable radio apparatus. and buoyant apparatus generally;

(iii) the launching of the lifeboats attached to davits;

(iv) the general preparation of the other boats, and buoyant apparatus;

(v) the muster of the passengers; and

(vi) the extinction of fire.

(e) The muster list shall assign to the members of the stewards' department their several duties in relation to the passengers in time of emergency. These duties shall include:-

(i) warning the passengers;

(ii) seeing that they are dressed and have put on their lifejackets in a proper manner;

(iii) assembling the passengers at muster stations;

(iv) keeping order in the passages and on the stairways, and, generally. controlling the movements of the passengers; and

(v) seeing that a supply of blankets is taken to the lifeboats.

(f) The muster list shall specify definite signals for calling all the crew to their boat and fire stations. and shall give full particulars of these signals.

\section{Regulation 21}

\section{Practice Musters and Drills}

(a) (i) In passenger ships, musters of the crew for boat drill and fire drill sball take place weekly when practicable. In passenger ships in which the voyage exceeds one week, there shall be such a muster before the ship leaves the final port of departure. 


\section{Règle 19}

\section{Signaux de Deitresse du Navire}

Tout navire doit être muni, à la satisfaction de l'Administration. de moyens lui permettant d'elfectuer des signaux de détresse efficaces, de jour et de nuit comprenant des signaux parachutes capables de produire une lumière rouge brillante à une haute altitude.

\section{Règle 20}

\section{Róle d'Appel et Consignes en Cas d'Urgence}

(a) Des fonctions spéciales à remplir en cas d'urgence doivent être assignées à chaque membre de l'équipage.

(b) Le rôle d'appel doit fixer ces fonctions spéciales et indiquer, en particulier, à quel poste chaque homme devra se rendre, ainsi que les fonctions qu'il aura à remplir.

(c) Le rôle d'appel doit être rédigé avaut le départ du navire. Des copies en seront affchées dans diverses parties du navire, et en particulier dans les locaux de l'équipage.

(d) Le rôle d'appel doit fxer les fonctions des divers membres de l'équipage en ce qui concerne :

(i) la fermeture des portes étanches, des vannes, les dispositifs de fermeture des dalots, des escarbilleurs, etc.;

(ii) l'armement des embarcations de sauvetage, y compris l'appareil de radio portatif et des engins flottants en général;

(iii) la mise à l'eau des embarcations sous bossoirs;

(iv) la préparation générale des embarcations et engins flottants:

(v) le rassemblement des passagers:

(vi) l'extinction de l'incendie.

(e) Le rôle d'appel doit fixer les devoirs respectifs des membres du personnel du Service Général envers les passagers en cas d'urgence. Ces devoirs compremnent :

(i) avertir les passagers;

(ii) vérifier qu'ils sont habillés et qu'ils ont mis leurs brassières de sauvetage d'une manière convenable;

(iii) réunir les passagers aux postes de rassemblement:

(iv) maintenir l'ordre dans les coursives et les escaliers et contrôler d'une manière générale les mouvements des passagers; et

(v) vérifier qu'un approvisionnement en couvertures a été placé dans les embarcations.

(f) Le rôle d'appel doit prévoir des signaux distincts pour l'appel de tout l'équipage aux postes d'embarcations et d'incendie, et donner les caractéristiques de ces signaux.

\section{Règle 21}

\section{Appels et Exercices}

(a) (i) Sur les navires à passagers, l'appel de l'équipage pour les exercices relatifs aux embarcations et à l'incendie doivent avoir lieu une fois par semaine, quand cela est praticable. Sur les navires à passagers qui effectuent des voyages d'une longueur supérieure à une semaine, ces appels auront lieu avant que le navire ne quitte le dernier port de départ; 
(ii) In cargo ships, a muster of the crew for boat drill and fire drill shall take place at intervals of not more than one month.

(iii) The dates upon which musters are held shall be recorded in such log book as may be prescribed by the Administration; and, if in any week (for passenger ships) or month (for cargo ships) a muster is not held, an entry shall be made stating why a muster was not practicable.

(b) In passcnger ships, except thosc engaged on short international voyages, a muster of the passengers shall be held within twenty-four hours after leaving port.

(c) Different groups of lifeboats shall be used in turn at successive boat drills. The drills and inspections shall be so arranged that the crew thoroughly understand and are practised in the duties they have to perform.

(d) The emergency signal for summoning passengers to muster stations shall be a succession of more than six short blasts followed by one long blast on the whistle or siren. This shall be supplemented on passenger ships, except those engaged in short international voyages, by other electrically operated signals throughout the ship controlled from the bridge. The meaning of all signals affecting passengers, with precise instructions on what they are to do in an emergency, shall be clearly stated in appropriate languages on cards posted in their cabins and in conspicuous places in other passenger quarters.

\section{P.ART B.-PASSENGER SHIPS ONLY}

(Part B applies to Passenger Ships only)

\section{Regulation 22}

\section{Lifeboats and Broyant Apparatus}

(a) Subject to the provisions of the following paragraphs of this Regulation, there must, in passenger ships, be accommodation in lifeboats for all persons on board, and there must, in addition, be buoyant apparatus for 25 per cent. of the persons on board. No more lifeboats shall be required on any passenger ship than are sulficient to accommodate all persons on board.

(b) In the case of passenger ships engaged on short international voyages, lifeboats and buoyant apparatus must be provided in accordance with the requirements set out for such ships in Regulations 23 and 24 . If the Administration considers that the carriage of passengers in excess of the lifeboat capacity so provided is necessitated by the volume of traffic, the Administration may permit this if the ship complies with the provisions applicable to this class of ship laid down in Regulation 1 (d) of Chapter $\Pi$.

(c) An Administration may permit individual ships or classes of ships with short international voyage certificates to proceed on voyages in excess of 600 miles, but not exceeding 1,200 miles, if such ships comply with the provisions of paragraph (b) of this Regulation and if they carry lifeboats which provide for at least 75 per cent. of the persons on board. 
(ii) Sur les navires de charge, un appel de l'équipage pour les exercices -embarcation et d'incendie doit avoir lieu à des intervalles ne dépassant pas in mois:

(iii) Les dates auxquelles ces appels ont lieu doivent être mentionnées à tel sumal de bord qui pourra être prescrit par l'Administration et, si. pendant ne semaine quelconque (pour les navires à passagers) ou d'un mois (pour es navires de charge), ces appels n'ont pas lieu. mention sera faite au journal le bord de la raison pour laquelle il a fallu s'en dispenser.

(b) Sur les navires à passagers. sauf sur ceux qui effectuent des voyages nternationaux courts, un appel des passagers doit avoir lieu dans les 24 leures qui suivent le départ.

(c) Divers groupes d'embarcations de sauvetage doivent ètre utilisées à our de rôle au cours des exercices successifs d'embarcations. Les exercices :t les inspections doivent être effectués de façon à ce que l'équipage comprenne plainement les fonctions qu'il sera appelé à remplir et s'y exerce.

(d) Le signal d'alerte pour l'appel des passagers aux postes de rassemblenent se compose d'une suite de plus de six coups brefs suivis d'un coup long du sifflet ou de la sirène. Sur les navires à passagers sauf sur ceux effectuant des voyages internationaux courts, ce signal sera complété par d'autres signaux produits électriquement dans tout le navire et mancuvrés de la passerelle de navigation. La signification de tous les signaux intéressant les passagers, avec des instrucrions précises sur ce qu'ils ont à faire en cas d'urgence. doivent étre clairement indiquées en langues appropriées dans des avis qui doivent être affichés dans leurs cabines et dans les endroits bien visibles dans d'autres parties des locaux à passagers.

\section{PARTIE B.-NAVIRES A PASSAGERS SELLEMENT}

(La partie B s'applique aux navires à passagers seulement)

\section{Règle 22}

\section{Embarcations de Sauvetage et Engins flottants}

(a) Sous réserve des prescriptions des paragraphes ci-dessous de la présente Règle, sur les navires à passagers, il doit y avoir dans les embarcations de sauvetage une place pour chaque personne présente à bord, et. en outre, des engins tlottants pour 25 pour cent des personnes présentes à bord. Sur aucun navire à passagers il ne peut être exigé plus d'embarcations de sauvetage qu'il n'est nécessaire pour recevoir toutes les personnes présentes à bord.

(b) Dans le cas de navires à passagers effectuant des voyages internationaux courts, des embarcations de sauvetage et des engins flottants doivent ètre installés de façon à satisfaire aux prescriptions formulées pour ces navires dans les Règles 23 et 24 . Si l'Administration considère que le transport de passagers. dépassant la capacité des embarcations prévue ci-dessus. est nécessité par le volume du trafic, cette Administration peut la permettre. à condition que le navire satisfasse aux prescriptions applicables à cette classe de navires, formulées dans la Règle I $(d)$ du Chapitre II.

(c) Une Administration peut permettre à des navires déterminés ou à des calégories de navires, en possession de certificats de voyage international court, d'effectuer des voyages dépassant 600 milles, mais ne dépassant pas 1,200 milles, pourvu que de tels navires satisfassent aux prescriptions du paragraphe (b) de la présente Règle et qu'ils portent des embarcations de sauvetage capables de contenir au moins 75 pour cent des personnes à bord. 
Regulation 23

Number of Davits and Capacity of Lifeboats and Buoyant Apparatus

(a) (i) A passenger ship shall be provided with sets of davits in accordance with its length as provided in Column $A$ of the Table in Regulation 24 except that a number of sets of davits greater than the number of lifeboats necessary for the accommodation of all the persons on board shall not be required.

(ii) Each set of davits shall have a lifeboat attached. If these lifeboats do not provide sufficient accommodation for all persons on board, additional sets of davits with lifeboats attached shall be fitted if practicable. If the lifeboats attached to davits do not provide accommodation for all persons on board, additional lifeboats shall be carried under the lifeboats attached to davits so that accommodation for all persons is provided.

(iii) When in the opinion of the Administration it is impracticable or unreasonable to place on a ship the number of sets of davits required by Column A of the Table in Regulation 24, the Administration may authorise. under exceptional conditions, a smaller number of sets of davits as specified in Column B of the Table.

(b) (i) A passenger ship engaged on a short international voyage shall be provided with sets of davits in accordance with its length as specified in Column $A$ of the Table in Regulation 24. Each set of davits shall have a lifeboat attached to it and these lifeboats shall provide at least the minimum capacity required by Column $C$ of the Table or the capacity required to provide accommodation for all persons on board if less. In the case of ships certified to carry a number of persons in excess of the lifeboat capacity specified in Column C. additional lifeboats under davits or approved buoyant apparatus shall be provided so that the total accommodation afforded by all the lifeboats, together with the buoyant apparatus, shall be sufficient for all on board. In addition there shall be buoyant apparatus for 10 per cent. of all on board.

(ii) When in the opinion of the Administration it is impracticable or unreasonable to place on a ship engaged on short international voyages the number of sets of davits required by Column A of the Table in Regulation 24. the Administration may authorise, under exceptional conditions, a smaller number of sets of davits, except that this number shall never be less than the minimum number fixed by Column $B$ of the Table, and that the total capacity of the lifeboats on the ship will be at least up to the minimum capacity required by Column $\mathrm{C}$ or the capacity required to provide for all persons on board if less.

(c) Passenger ships shall carry two boats attached to davits - one on each side of the ship-for use in an emergency. These boats shall be of a type approved by the Administration and shall normally be not more than 26 feet (or 8 metres) in length. They may be counted for the purposes of Regulation 22. provided that they comply fully with the requirements of this Chapter for lifeboats. They shall be kept ready for immediate use while the ship is at sea. In ships in which the requirements of Regulation $26(j)$ are met by means of appliances fitted to the sides of the lifeboats. such appliances shall not be required to be fitted to the two boats provided to meet the requirements of this Regulation. 
Règle 23

\section{Nombre de Bossoirs el capacité des Embarcations de Sauverage ef des Engins Rorrcints}

(a) (i) Tout navire à passagers doit avoit un nombre de jeux de bossoirs déterminé d'après sa longueur, par la colonne $A$ du tableau inséré à la Règle 24, sous réserve qu'il ne sera pas exigć un nombre de jeux de bossoirs supérieur à celui des embarcations de sauvetage nécessaires pour recevoir toutes les personnes présentes à bord.

(ii) Sous chaque jeu de bossoirs doit être attaché une embarcation de sauvetage. Si ces embarcations de sauvetage ne fournissent pas une place suffisante pour recevoir toutes les personnes présentes à bord. des jeux de bossoirs additionels auxquels seront attachées des embarcations de sauvetage. doivent éure installés si possible. Si les embarcations de sauvetage attachées aux bossoirs ne fournissent pas une place suffisante pour toutes les personnes présentes à bord, des embarcations de sauvetage additionnelles seront installées au-dessous des embarcations de sauvetage attachées aux bossoirs de façon à fournir une place pour chaque personne présente à bord.

(iii) Lorsque dans l'opinion d'une Administration, il est impraticable ou déraisonnable de mettre sur un navire le nombre de jeux de bossoirs exigé par la colonnne A du tableau insérć à la Règle 24, cette Administration peut. dans certains cas exceptionnels, autoriser une réduction du nombre de jeux de bossoirs, comme spécifié dans la colonne B du tableau.

(b) (i) Un navire à passagers affecté à des voyages internationaux courts doit avoir un nombre de jeux de bossoirs déterminé d'après sa longueur par la colonne A du tableau inséré à la Règle 24. Une embarcation de sauvetage doit étre attachée à chaque jeu de bossoirs. Ces embarcations de sauvetage doivent avoir au moins la capacité minimum prescrite par la colonne $C$ du tableau. ou la capacité suffisante pour recevoir toutes les personnes présentes à bord. si ce nombre est inférieur au premier. Dans le cas de navires admis à transporter un nombre de personnes dépassant la capacité des embarcations de sauvetage

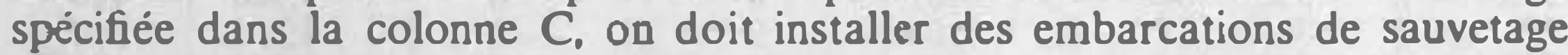
additionnelles sous bossoirs ou des engins flottants d'un type approuvé, de façon à ce que la place fournie par toutes les embarcations de sauvetage, y compris les engins flottants, soit suffisante pour recevoir toutes les personnes présentes à bord. En outre, il doit y avoir des engins flottants pour 10 pour cent des personnes présentes à bord.

(ii) Lorsque, dans l'opinion d'une Administration, il n'est ni praticable, ni raisonnable de mettre sur un navire effectuant des voyages internationaux courts le nombre de jeux de bossoirs exigé par la colonne A du tableau inséré à la Règle 24, l'Administration peut. dans certains cas exceptionnels. autoriser une réduction dans le nombre de jeux de bossoirs. pourvu toutefois. que ce nombre soit au moins égal au nombre réduit exigé par la colonne B du tableau, et aussi que la capacité totale des embarcarions de sauvetage du navire soit au moins égale au minimum exigé par la colonne $C$ ou égale à la capacité nécessaire pour recevoir toutes les personnes présentes à bord, si le nombre de celles-ci est inférieur au premier.

(c) Les navires à passagers doivent porter deux embarcations attachées aux bossoirs - une de chaque bord du navire-pour servir en cas d'urgence. Ces embarcations doivent être d'un type approuvé par l'Administration et ne dépasseront pas normalement une longueur de 8 mètres (ou 26 pieds). Elles peuvent entrer en compte pour satisfaire à la Règle 22, pourvu qu'elles répondent complètement aux conditions des embarcations de sauvetage du present chapitre. Elles doivent êtres tenues prêtes pour un usage immédiat pendant que le navire est en mer. Sur les navires sur lesquels. en conformité avec la Règle 26 (j). des dispositifs sont fixés aux côtés des embarcations de sauvetage il n'est pas nécessaire de munir de ces dispositifs les deux embarcations mises à bord pour satisfaire aux stipulations de la présente Règle. 
Chap. III

156

Regulation 24

Table relating to Davits and Lifeboat Capacity

The following table fixes according to the length of the ship-

(A) The minimum number of sets of davits to be provided to each of which must be attached a lifeboat in accordance with Regulation 23 above;

(B) the smaller number of sets of davits which may be authorised exceptonally under Regulation 23; and

(C) the minimum lifeboat capacity required for a ship engaged on short international voyages.

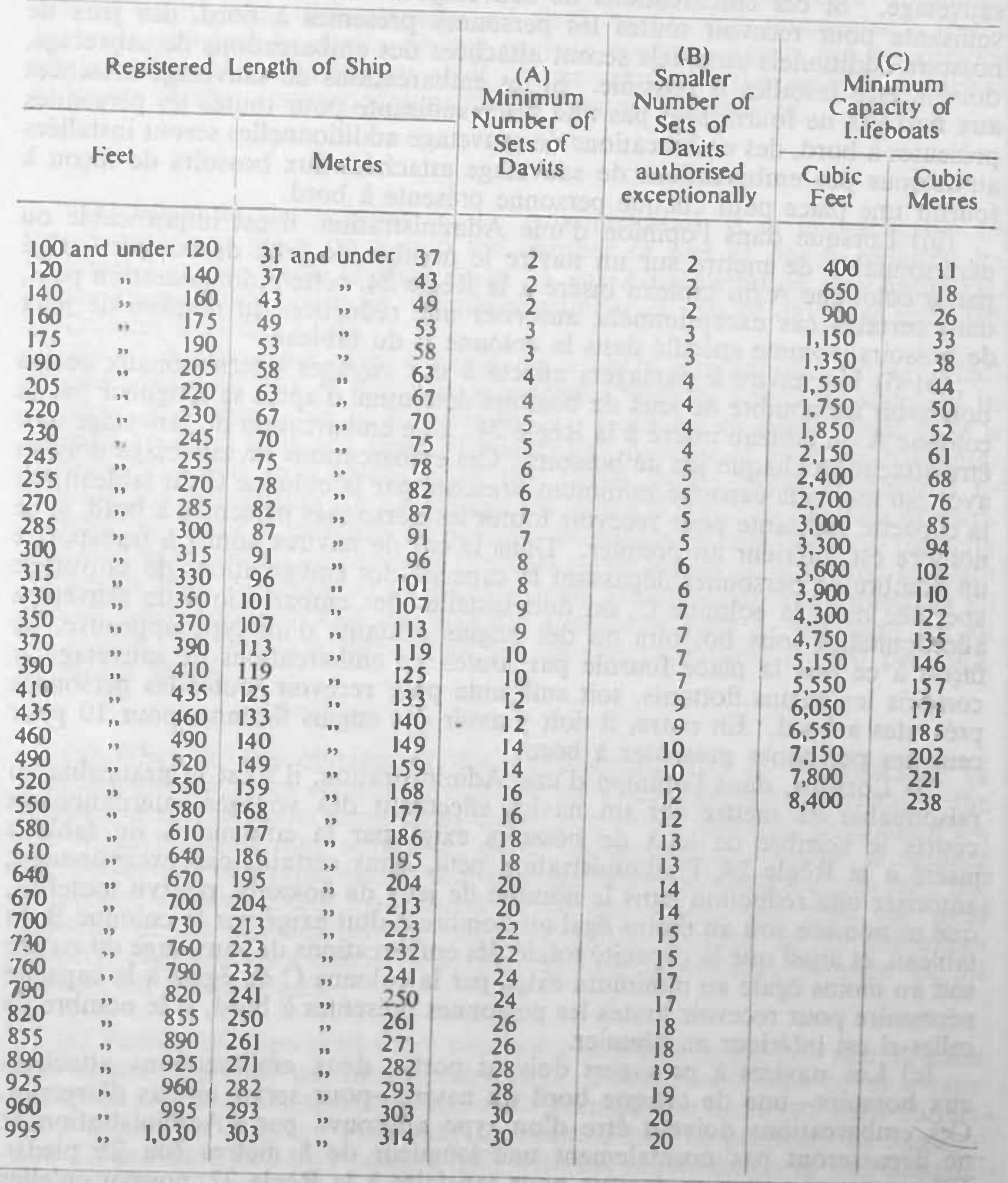

Note on (A) and (B). - When the length of the ship exceeds I,030 feet (or 314 metres) the Administration shall determine the minimum number of sets of davits for that ship. Note on (C). - When the length of the ship is under 100 feet (or 31 metres) or over 550 feet (or 168 metres) the cubic capacity of the lifeboats shall be prescribed by the Administration. 


\section{Regulation 25}

\section{Radio Apparatus and Searchlights in Molor Lifeboats}

(a) Every motor lifeboat of Class A. required to be carried in compliance with paragraphs $(a)$ and $(b)$ of Regulation 8 . must be filled with a radiotelegraph installation complying with the requirements set out in this Regulation and in Regulation 13 of Chapter IV. and also with a searchlight complying with paragraph $(f)$ of this Regulation.

(b) The radio installation shall be installed in a cabin large enough to accommodate both the equipment and the person using it.

(c) The arrangements shall be such that the efficient operation of the transmitter and receiver shall not be interfered with by the engine while it is running. whether a battery is on charge or not.

(d) The radio battery shall not be used to supply power to any enginestarting motor or ignition systcm.

(e) The motor lifeboat cngine shall be flted ivith a dynamo for recharging the radio battery, and for other services.

(f) The searchlight shall include a lamp of at least 80 watts, an efticient reflector and a source of power which will give effective illumination of a light-coloured object having a width of about 60 feet (or 18 metres) at a distance of 200 yards (or 180 metres) for a total period of six hours and shall be capable of working for at least three hours continuously.

\section{Regulation 26}

\section{Sronage and Handling of Lifeboars}

(a) Lif eboats shall be stowed to the satisfaction of the Administration in such a way that -

(i) they can be launched in the shortest possible time;

(ii) they will not impede in any way the prompt bandling of any of the other lif ebo:tts attached to davits or stowed under lif eboats attaclied to davits or the buoyant apparatus or the marshalling of the persons on board at the launching stations, or their embarkation: and

(iii) even under conditions of list and trim unfavourable from the point of view of the handling of the lifeboats, as large a number of persons as possible can be embarked in them.

(b) Where practicable not more than one lifeboat shall be served by a single set of davits. In ships where this arrangement is impracticable. the lifeboats may, subject to the foregoing provisions, be stowed one above the other, or they may, subject to such conditions as the Administration may impose. be fitted one within another, but where lifeboats so fitted require lifting before being launched mechanical power appliances for lifting shall be provided.

(c) Where a lifeboat is stowed underneath another lifeboat. there shall be provided approved removable supports or other approved appliances. so as to secure that the weight of a lifeboat is not unduly supported by the lifeboat underneath it.

(d) Lifeboats may only be stowed on more than one deck on condition that proper measures are taken to prevent lifeboats on a lower deck being fouled by those stowed nn a deck above. 


\section{Règle 25}

\section{Appareil de Radio el Projecteur dans les Embarcurions de Sauverage à moreur}

(a) Toute embarcation de sauvetage à moteur de la Classe $\mathrm{A}$, lorsqu'elle est exigée pour satisfaire aux paragraphes $(a)$ et $(b)$ de la Règle 8. doit être munie dune installation radiotélégraphique, satisfaisant aux prescriptions de la présente Règle et de la Règle 13 du Chapitre IV et d'un projecteur répondant aux prescriptions du paragraphe $(f)$ de la présente Règle.

(b) L'équipement de radiotélégraphie doit être installé dans une cabine assez grande pour contenir en même temps l'équipement et son utilisateur.

(c) Des mesures doivent être prises pour que le fonctionnement de l'émetteur et du récepteur ne soit pas gêné par le moteur en marche, que la batterie soit sur la charge ou non.

(d) La batterie de la radio ne doit pas être utilisée pour alimenter un dispositif de lancement de moteur ou un système d'allumage quel qu'il soit.

(e) Le moteur de l'embarcation de sauvetage doit être équipé avec une dynamo pour la recharge de la batterie de la radio, et pour tout autre usage.

(f) Le projecteur doit comporter une lampe d'au moins 80 watts, un réflecteur efficace et une source d'énergie permettant d'éclairer efficaceinent un objet de couleur claire d'une largeur d'environ 18 mètres (ou 60 pieds) à une distance de 180 mètres (ou 200 yards) pendant une durée totale de 6 heures, et pourra fonctionner sans interruption pendant au moins 3 heures.

\section{Règle 26}

\section{Installasion et Mancuuve des Embarcasions de Salverage}

(a) Les embarcations de sauvetage doivent être installées à la satisfaction de l'Administration, de telle façon que:

(i) elles puissent être mises à l'eau dans un temps aussi court que possible;

(ii) elles n'empêcheront d'aucune manière la manœuvre rapide des autres embarcations de sauvetage attachées aux bossoirs, ou arrimées sous les embarcations de sauvetage attachées aux bossoirs, ou les engins flottants, le rassemblement des personnes présentes à bord aux postes d'évacuation ou leur embarquement: et

(iii) même sous des conditions défavorables de bande et d'assiette, au point de vue de la manouvre des embarcations de sauvetage, un nombre de personnes aussi grand que possible puisse y être embarqué.

(b) Lorsque cela est possible une embarcation de sauvetage seule sera desservie par un seul jeu de bossoirs. Sur les navires où cette disposition n'est pas réalisable les embarcations de sauvetage peuvent, sous réserve des dispositions qui précèdent, être placées l'une au-dessus de l'autre; ou sous certaines conditions que pourra imposer l'Administration, elles peuvent étre placées l'une dans l'autre; toutefois. quand des embarcations de sauvetage ainsi disposées doivent être soulevées avant d'être mises à l'eau, des appareils mécaniques à moteur seront prévus pour les soulever.

(c) Quand une embarcation de sauvetage est placée sous une autre, elle doit être munie de supports appropriés amovibles ou de tout autre dispositif d'un modèle aprouvé. en vue d'éviter que le poids de l'embarcation de sauvetage supérieure soit mal réparti sur l'embarcation de sauvetage inférieure.

(d) Les embarcations de sauvetage ne peuvent être placées sur plus d'un pont que si des mesures approprices sont prises pour éviter que les embarcations de sauvetage d'un pont inférieur ne soient gênées par les embarcations de sauvetage placées sur le pont au-dessus. 
(e) Lifeboats shall not be placed in the bows of the ship. They shall bx stowed in such positions as to ensure safe launching.

(5) Davits shall be of approved form and shall be suitably placed to the satisfaction of the Administration. They shall be so disposed on one or more decks that the lifeboats placed under them can be safely lowered without interference from the operation of any other davits.

(g) In ships over 150 feet (or 46 metres) in length, the davits shall be as follows:-

(i) luffing or gravity type for operating lifeboats weighing not more than 4 tons (or 4,064 kilogrammes) in their turaing out condition;

(ii) gravity type for operating lifeboats weighing more than 4 tons (or 4.064 kilogrammes) in their turning out condition.

(h) In ships not exceeding 150 feet (or 46 metres) in length, the davits if of radial type shall be fitted with approved means to prevent them from being jerked from their sockets.

(i) The davits, falls, blocks and all other gear shall be of such strength that the lifeboats can be safely lowered with the full complement of persons and equipment, with the ship listed to 15 degrees either way.

(i) In ships in which the boat deck is more than 15 feet (or 4.6 metres) above the deepest sea-going draught arrangements shall be made to facilitate launching the lifeboats against an adverse list.

(k) The iifeboats. except the emergency boats referred to in Regulation 23 shall be served by wire rope falls, together with winches of an approved type. but the Administration may allow manila rope falls with or without winches to be Gitted in ships where, having regard, for example, to the height of the boat deck above the lightest sea-going draught, they are satisfied that manila rope falls are adequate.

(l) Two lifelines shall be fitted to the davit spans, and the falls and lifelines shall be long enough to reach the water with the ship at its lightest sea-going draught and listed to 15 degrees either way. Lower fall blocks shall be fitted with a suitable ring or long link for attaching to the sling hooks unless an approved type of disengaging gear is fitted.

(m) Lifeboats attached to davits shall have the falls ready for service, and arrangements shall be made for speedily, but not necessarily simultaneously. detaching the lifeboats from the falls. The points of attachment of the lifeboats to the falls shall be so situated as to ensure the lifeboats being easily swung clear of the davits.

(n) If more than one lifeboat is served by the same set of davits, separate falls shall be provided to serve each lifeboat. unless the falls are of wire rope. The appliances used shall be such as to ensure lowering the lifeboats rapidly and in turn. Where mechanical power appliances are fitted for the recovery of the falls, eflicient hand gear shall also be provided. 
(e) On ne doit pas mettre d'embarcations de sauvetage à l'extrême avant du navire. Les embarcations de sauvetage doivent être disposées de telle manière qu'elles puissent être mises à l'eau avec sécurité.

$(f)$ Les bossoirs doivent être de forme approuvée, et doivent être disposés à la satisfaction de l'Administration. Is doivent être disposés sur un ou plusieurs ponts de telle sorte que les embarcations de sauvetage placées audessous d'eux puissent être mises à l'eau avec sécurité sans être gênées par la manouvre des autres bossoirs.

(g) Sur les navires de plus de 46 metres (ou 150 pieds) de longueur les bossoirs doivent être:

(i) du type oscillant ou du type à gravité pour la manæuvre des embarcations de sauvetage d'un poids ne dépassant pas $4064 \mathrm{~kg}$. (ou 4 Tonnes anglaises) dans leur état de mise à l'eau sans passagers:

(ii) du type à gravité pour la manœuvre d'embarcations d'un poids supérieur à $4064 \mathrm{~kg}$. (ou 4 Tonnes anglaises) dans leur citat de mise à l'eau sans passagers.

(h) Sur les navires dont la longueur ne dépasse pas 46 mètres (ou 150 pieds) lorsqu'ils sont équipis de hossoirs du type pivotant, ceux-ci doivent être munis de dispositifs d'un modèle approuvé, qui les empécheront de sortir de leur crapaudine.

(i) Les bossoirs, garants, poulies, et autres appareils doivent avoir une résistance suffisante pour permettre de mettre à l'eau avec sécurité les embarcations de sauvetage avec leur complet chargement de personnes et de matériel, même si le navire a une bande de $15^{\circ}$ d'un bord queiconque.

(j) Sur les navires dont le pont des embarcations est d'unc hauteur supérieure à $4 \mathrm{~m}$. 60 (ou 15 pieds) au-dessus de la ligna de flottaison correspondant au tirant d'eau maximum en eau de mer, des mesures seront prises pour faciliter la mise à l'eau sous des conditions défavorablis de bande.

(k) Les embarcations de sauvetage. à l'exception des embarcations de secours, mentionnées à la Règle 23, seront desservies par des garants métalliques, ainsi que par des treuils d'un modèle approuvé. Mais l'Administration peut permettre l'installation de garants en cordage de manille avec ou sans treuils sur des navires, quand elle estime que des garants en cordage de manille sont suffisants, tout en tenant compte, entre autres, de la hauteur du pont des embarcations au-dessus de la ligne de flottaison correspondant au tirant d'eau minimum en eau de mer.

(l) Deux tireveilles doivent être attachées aux extrémités des bossoirs: les garants et les tireveilles doivent être assez longs pour atteindre l'eau lorsque le navire est à son tirant d'eau le plus faible en eau de mer et avec une bande de $15^{\circ}$ d'un bord ou de l'autre. Les poulies inférieures doivent être munies d'un anneau ou d'une maille allongée disposés pour être passés dans les crocs de suspente, à moins que ne soit installé un dispositif d'échappement d'un modèle approuvé.

(in) Les embarcations de sauvetage attachées aux bossoirs doivent avoir leurs palans prêts à être utilisés et des dispositions doivent être prises pour que les embarcations soient rapidement libérées des palans, sans qu'il soit nécessaire que cette manauvre soit simultanée pour les deux palans. Les points d'attache des embarcations de sauvetage aux palans seront placés de telle sorte que les embarcations de sauvetage puissent être facilement dégagées des bossoirs.

(n) Lorsque le même jeu de bossoirs sert pour plus d'une embarcation de sauvetage il doit y avoir des palans distincts pour chaque embarcation de sauvetage, à moins que les garants ne soient métalliques. Les appareils employés doivent permettre de mettre à l'eau les embarcations de sauvetage à tour de rôle et rapidement.

43055 


\section{Regulation 27}

Lighsing for Decks. Lifeboars, \&c.

(a) Provision shall be made for an electric or other system of lighting, sufficient for all requirements of safety, in the different parts of a passenger ship. and particularly upon decks on which the lifeboats are stowed. Provision shall also be made for the illumination of the launching gear, and the lifeboats in process of, and immediately after, being launched. The selfcontained emergency source of electrical power required by Regulation 22 of Chapter II shall be capable of supplying, when necessary. this lighting system.

(b) The exit from every main compartment occupied by passengers or crew shall be continuously lighted by an emergency lamp. The power for these emergency lamps shall be so arranged that they will be supplied from the emergency source of power referred to in paragraph $(a)$ of this Regulation in the event of failure of the main generating plant.

\section{Regulation 28}

\section{Manning of Lifeboars}

(a) A deck officer or certilicated lifeboatman shall be placed in charge of each lifeboat and a second-in-command shall also be nominated. The person in charge shall have a list of the lifeboat's crew, and shall see that the men placed under his orders are acquainted with their several duties.

(b) A man capable of working the motor shall be assigned to each motor lifeboat.

(c) A man capable of working the radio and searchlight installations shall be assigned to each lifeboat carrying this equipment in accordance with Regulation 25.

\section{Regulation 29}

\section{Cerrificased Lifeboasmen}

(a) In passenger ships there must be, for every lifeboat carried in order to comply with this Chapter. a number of lifeboatmen at least equal to that specified in the following table:-

\section{Prescribed Complemens of Lifeboas}

The Minimum Number of Cerrificased Lifeboar-

Less than 41 persons

From 41 to 61 persons

From 62 to 85 persons

Above 85 persons men shall be

(b) The allocation of the certificated lifeboatmen to each lifeboat remains within the discretion of the master.

(c) By "certificated lifeboatman" is meant any member of the crew who holds a certificate of efficiency issued under the authority of the Administration.

(d) In order to obtain this certificate. the applicant must prove that he has been trained in all the operations connected with launching lifeboats and the use of oars; that he is acquainted with the practical handling of the boats themselves; and, further. that he is capable of understanding and answering the orders relative to lifeboats. 
Lorsqu'un dispositif mécanique à moteur est employé pour rentrer les garants, il dnit être complété par une commande à main efficace.

\section{Règle 27}

Eclairage des Ponts. Embarcations, etc.

(a) Un eclairage électrique ou autre, suffisant pour satisfaire aux exigences de la sécurité, doit être prévu dans les diverses parties d'un navire à passagers et particulièrement sur les ponts où se trouvent les embarcations de sauvetage. Des dispositions doivent ètre prises également pour l'éclairage des dispositifs de mise à l'eau, et des embarcations de sauvetage pendant leur mise à l'eau immédiatement après. La source autonome de secours du groupe électrique prescrite par la Règle 22 du Chapitre II, doit être capable d'alimenter, le cas écheant, les appareils de cet éclairage.

(b) La sortie de chaque tranche principale de cloisonnement occupée par les passagers ou l'équipage. doit étre éclairée en permanence par une lampe de secours. L'alimentation de ces lampes de secours doit pouvoir être fournie par la source autonome de secours visée au paragraphe (a) de la présente Règle en cas d'arrêt de la source principale d'éclairage du navire.

\section{Règle 28}

\section{Personnel des Embarcations de Sauverage}

(a) Un officier de pont ou un canotier breveté doit être chargé de chaque embarcation de sauvetage et il lui sera également désigné un suppléant. Celui qui est chargé d'une embarcation doit avoir la liste de son personnel et s'assurer que les hommes placés sous ses ordres sont au courant de leurs diverses fonctions.

(b) A toute embarcation de sauvetage à moteur doit être affecté un homme sachant conduire le moteur.

(c) Un homme capable de faire fonctionner l'installation radiotélégraphique et le projecteur, doit étre affecté à chaque embarcation de sauvetage comportant ces appareils conformément à la Règle 25.

\section{Règle 29}

\section{Canotiers bievetés}

(a) Sur tout navire à passagers il doit y avoir four chaque embarcation mise à bord conformément aux prescriptions du présent chapitre, un nombre de canotiers au moins égal à celui qui est prévu au tableau ci-après:-

Nombre de persomes prévues par embarcation

Moins de 41 personnes

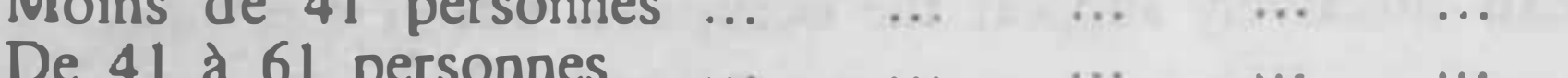

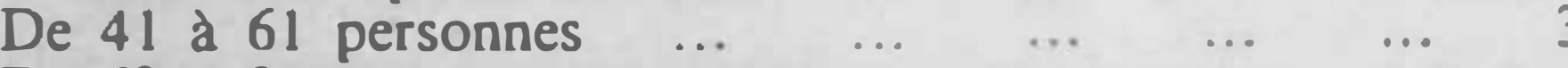

$\begin{array}{llllllll}\text { De } 62 \text { à } 85 \text { personnes } & \ldots & \ldots & \ldots & \ldots & \ldots & 4\end{array}$

Au-dessus de 85 personnes $\quad \ldots \quad$...

(b) La désignation pour chaque embarcation de sauvetage des canotiers brevetés est laissée à la discrétion du capitaine.

(c) L'expression "canotier breveté" désigne tout membre de l'équipage qui est possesseur d'un certificat d'aptitude délivré avec l'autorisation de l'Administration.

(d) Pour obtenir ce certificat le candidat doit prouver qu'il a été entrainé à toutes les mancuuvres relatives à la mise à l'eau des embarcations de sauvetage et à l'usage des avirons, et qu'il est familier avec les mancuvres des embarcations elles-mèmes; et de plus qu'il est capable de comprendre les ordres relatifs aux embarcations de sauvetage et de les exécuter.

43055 


\section{Regulation 30}

\section{Buojane Apparatus and Liferalts}

(a) The expression "buoyant apparatus" means flotation equipment (other than lifeboats, lifebuoys and lifejackets) designed to support a specified number of persons who are in the water and of such construction that it retains its shape and properties.

(b) No type of buoyant apparatus may be approved unless it satisfies the following conditions:-

(i) It shall be of such size and strength that it can be thrown from the place where it is stowed into the water without being damaged.

(ii) It shall not exceed $400 \mathrm{lbs}$. in weight (or 180 kilograms) unless suitable means to the satisfaction of the Administration are provided to enable it to be launched without lifting by hand.

(iii) It shall be of approved material and construction.

(iv) It shall be effective and stable when floating either way up.

(v) The air cases or equivalent buovancy shall be placed as near as possible to the sides of the apparatus, and such buoyancy shall not be dependent upon inflation.

(vi) It shall be fitted with a painter and have a line securely becketed round the outside.

(c) The number of persons for which buoyant apparatus is certified shall be the number,

(i) ascertained by dividing the number of pounds of iron which it is capable of supporting in fresh water by 32 (or the number of kilogrammes divided by $14 \cdot 5$ ). or

(ii) equal to the number of feet (equivalent to 30.5 centimetres) in the perimeter

whichever is the less.

(d) Liferafts mav be carricd in lieu of buoyant apparatus, provided that, in addition to complying with the requirements of sub-paragraphs (ii), (iii), (iv). (v) and (vi) of paragraph (b) of this Regulation each liferaft satisfies the following conditions:

(i) It shall be of such strength that it can be launched or thrown from the place where it is stowed into the water without being damaged.

(ii) It shall have not less than three cubic feet (or 85 cubic decimetres) of air cases or equivalent buoyancy for each person it is certified to carry.

(iii) It shall have a deck area of not less than four square feet (or 3.720 square centimetres) for each person it is certified to carry, and it shall effectively support the occupants out of the water.

(iv) It shall be equipped with two paddles.

\section{Regulation 31}

\section{Number of Lifebuoys to be Provided}

The minimum number of lifebuoys with which passenger ships are to be provided is lixed by the following table:-

$$
\text { in Feet Length of Ship in Metres Minimum Number }
$$

\section{in Merres}

Under 200

200 and under 400

400 and under 600

600 and under 800

800 and over
Under 61

61 and under 122

122 and under 183

183 and under 244

244 and over 


\section{Règle 30 \\ Engins flottants el Radeaux de Sauverage}

(a) L'expression "engin flottant" désigne un matériel flottant (autre que les embarcations de sauvetage les bouées et les brassières de sauvetage). destiné à supporter un nombre déterminé de personnes que se trouvent dans l'eau, et d'une construction telle qu'il conserve sa forme et ses caractéristiques.

(b) Un type d'engin flottant ne peut être approuvé s'il ne satisfait aux conditions suivantes:

(i) il doit avoir des dimensions et une résistance telle qu'il puisse être jeté dans l'eau sans dommage de l'endroit où il est arrimé;

(ii) il ne sera pas d'un poids superieur à $180 \mathrm{~kg}$. (ou 400 livres anglaises) à moins que des dispositifs appropriés ne soient installés à la satisfaction de l'Administration afin d'en permettre la mise à l'eau sans qu'il y ait besoin de le soulever à la main;

(iii) il doit être de matière et de construction approuvées:

(iv) il doit être utilisable et stable, quelle que soit la face sur laquelle il flotte;

(v) les caissons à air ou les flotteurs équivalents doivent être placés aussi près que possible des côtés de l'engin et il ne faut pas que la flottabilité de cet engin dépende d'une insufflation préalable;

(vi) il sera muni d'une bosse et aura une filière en guirlande solidement attachée autour de la paroi extérieure.

(c) Le nombre de personnes pour lesquelles un engin flottant est autorise doit être le plus petit des deux nombres obtenus en divisant :

(i) le nombre de kilogrammes de fer qu'il est capable de supporter en eau douce par 14.5 (ou le nombre de livres anglaises par 32); et

(ii) le périmètre de l'engin. exprimé en centimètres, par 30.5 .

(d) Des radeaux de sauvetage peuvent être einbarqués au lieu d'engins flottants à la condition qu'ils satisfassent d'abord aux prescriptions des alinéas (ii), (iii), (iv). (v) et (vi) du paragraphe (b) de la présente Règle et en outre aux conditions suivantes:

(i) ils doivent avoir une résistance suflisante pour être lancés ou jetés à l'eau sans avarie de l'endroit où ils sont arrimés:

(ii) ils ne doivent pas avoir moins de 85 décimètres cubes ( 3 pieds cubes) de caissons à air ou de flotteurs équivalents, pour chaque personne qu'ils sont autorisés à porter:

(iii) ils doivent avoir une surface de pont d'au moins 3.720 centimètres carrés (ou 4 pieds carrés) pour chaque personne qu'ils sont autorisés à porter, et les personnes qu'ils portent doivent être effectivement hors de l'eau;

(iv) ils seront munis de deux pagaies.

\section{Règle 31}

Nombre de Bouées de Sauverage

Le nombre minimum de bouées de sauvetage dont il faut munir les navires à passagers est fixé par le tableau suivant:

\section{Longueur du Navire}

en mètres

Au-dessous de 61

61 et au-dessous de 122

122 et au-dessous de 183

183 et au-dessous de 244

244 et au-dessus en pieds

Au-dessous de 200

200 et au-dessous de 400

400 et au-dessous de 600

600 et au-dessous de 800

800 et au-dessus
Nombre minimum de Bouées

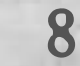

12

18

24

30 


\section{PART C.-CARGO SHIPS ONLY}

(Part C applies to cargo ships only)

\section{Regulation 32}

Number and Capacity of Lifeboats

(a) Cargo ships, except those employed as whale factory ships, shall carry lifeboats attached to davits on each side of the ship of such aggregate capacity as will accommodate all persons on board.

(b) Every ship employed as a whale factory ship shall carry lifeboats attached to davits on each side of the ship of such aggregate capacity as will acommodatc every member of the crew engaged to work the ship. In addition, every such ship shall carry lifeboats of aggregate capacity sulficient to accommodate the total number of additional persons which the ship carries. These additional lifeboats shall. where practicable, be attached to davits. If not attached to davits, they shall be stowed under lifeboats attached to davits.

(c) Every tanker of 3.000 tons gross tonnage and upwards shall carry not less than four lifeboats attached to davits, two of which shall be carried aft and two amidships.

\section{Regulation 33}

\section{Davits and Launching Arrangements}

(a) In cargo ships lifeboats attached to davits shall be stowed to the satisfaction of the Administration.

(b) Lifeboats shall not be placed in the bows of the ship. They shall be stowed in such positions as to ensure safe launching.

(c) Davits shall be of approved form and shall be suitably placed to the satisfaction of the Administration.

(d) In ships of over 150 feet (or 46 metres) in length the davits shall be as follows:-

(i) Luffing or gravity type for operating lifeboats weighing not more than 4 tons (or 4.064 kilogrammes) in their turning out condition:

(ii) gravity type for operating lifeboats weighing more than 4 tons (or 4,064 kilogrammes) in their turning out condition.

(e) In cargo ships not exceeding 150 feet (or 46 metres) in length, the davits if of radial type shal] be fitted with approved means to prevent them from being jerked from their sockets.

$(f)$ The davits, falls, blocks and all other gear shall be of such strength that the lifeboats can be safely lowered with the full complement of persons and equipment, with the ship listed to 15 degrees either way.

(g) In cargo ships in which the boat deck is more than 15 feet above the deepest sea-going draught arrangenients shall be made to facilitate launching the lifeboats against an adverse list. 


\section{PARTIE C.-NAVIRES DE CHARGE SEULEMENT}

\section{(La partie $C$ s'applique exclusivement aux navires de charge)}

\section{Règle 32}

\section{Nombre et capacité des Embarcations de Sauvetage}

(a) Les navires de charge excepté les navires employés comme naviresusines dans la chasse à la baleine, doivent avoir des embarcations de sauvetage attachées aux bossoirs, de chaque bord, d'une capacité totale telle qu'elles puissent recevoir toutes les personnes présentes à bord.

(b) Tout navire employé comme navire-usine dans la pêche à la baleine. doit avoir des embarcations attachées aux bossoirs, de chaque bord, d'une capacité totale telle qu'elles puissent recevoir tous les membres de l'équipage engagés pour armer le navire. En outre, les navires de cette catégorie doivent avoir à bord des embarcations de sauvetage d'une capacité totale suffisante pour recevoir la totalité des personnes supplémentaires présentes à bord. Ces embarcations de sauvetage additionnelles seront, quand il est possible, attachées aux bossoirs. Si elles ne sont pas attachées aux bossoirs. elles doivent être placées sous les embarcations de sauvetage attachées aux bossoirs.

(c) Tout navire-citerne de 3,000 tonneaux de jauge brute et au-dessus doit avoir à bord, au moins 4 embarcations de sauvetage attachées aux bossoirs. dent deux seront à l'arrière et deux au milieu du navire.

\section{Règle 33}

\section{Bossoirs et Dispositils de Mise ḋ l'Eun}

(a) Sur les navires de charge, toutes les embarcations de sauvetage attachées aux bossoirs doivent être disposées à la satisfaction de l'Administration.

(b) Les embarcations de sauvetage ne doivent pas êtres placées à l'extrême avant du navire. Elle doivent être disposées de manière à pouvoir être mises à l'eau avec sécurité.

(c) Les bossoirs doivent être d'une forme approuvée ct disposés d'une manière convenable à la satisfaction de l'Administration.

(d) Sur les navires de plus de $46 \mathrm{~m}$. (ou 150 pieds) de longueur, les bossoirs doivent être :

(i) du type oscillant ou du type à gravité pour la manœuvre des embarcations de sauvetage d'un poids ne dépassant pas $4064 \mathrm{Kg}$. (ou 4 tonnes anglaises) dans leur état de mise à l'eau sans passagers:

(ii) du type à gravité pour la ruanauvre des embarcations d'un poids supérieur à $4064 \mathrm{Kg}$. (ou 4 tonnes anglaises) dans leur état de mise à l'eau sans passagers.

(e) Sur les navires de charge dont la longueur ne dépasse pas $46 \mathrm{~m}$. (ou 150 pieds) les bossoirs, s'ils sont du type pivotant, doivent être munis de dispositifs d'un modèle approuvé qui les empêchent de sortir de leur crapaudine.

(f) Les bossoirs, garants, poulies, et autres appareils doivent avoir une résistance suffisante pour pernnettre de mettre à l'eau avec sécurité, les embarcations de sauvetage avec leur chargement complet de personnes et de matériel. si le navire a une bande de $15^{\circ}$ d'un bord quelconque.

(g) Sur les navires de charge dont le pont des embarcations est à une hauteur supérieure à $4.50 \mathrm{~m}$. (ou 15 pieds) au-dessus de la ligne de flottaison correspondant au tirant d'eau maximum en eau de mer, des mesures doivent être prises pour faciliter la mise à l'eau dans des conditions défavorables de bande. 
(h) The lifeboats shall be served by wire rope falls together with winches of an approved type, but the Administration may allow manila rope falls with or without winches to be fitted in ships where, having regard, for example, to the height of the boat deck above the lightest sea-going draught, they are satisfied that manila rope falls are adequate.

(i) Two lifclines shall be fitted to the davit spans and the falls and lif elines shall be long enough to reach the water with the ship at her lightest sea-going draught and listed to 15 degrees either way. Lower fall blocks shall be fitted with a suitable ring or long link for attaching to the sling hooks unless an approved type of disengaging gear is fitted.

(j) Lifeboats attached to davits shall have the falls ready for service. and arrangements shall be made for speedily, but not necessarily simultaneously. detaching the lifeboats from the falls. The points of attachment of the lifeboats to the falls shall he so situated as to ensure the lifeboats being easily swung clear of the davits.

\section{Regulation 34}

\section{Number of Lifebuoys 10 be Provided}

(a) At least eight approved lifebuoys of a type which satisfies the requirements of Regulation 16 shall be carried. All the lifebuoys shall be fitted with beckets securely seized.

(b) At least half the lifebuoys shall be provided with approved self-igniting lights which cannot be extinguished by water. Self-igniting lights shall be kept near the lifebuoys to which they belong. with the necessary means of attachment. At least one lifebuoy on each side of the ship shall be fitted with a lifeline at least 15 fathoms (or 27.5 metres) in length.

(c) In the case of tankers, the self-igniting lights shall be of the electric battery type. 
(h) Les embarcations de sauvetage doivent être desservies par des garants métalliques, ainsi que par des treuils d'un modèle approuvé; mais l'Administration peut permettre l'installation de garants en cordage de manille avec ou sans treuils quand elle estime que des garants en cordage de manille sont suffisants. tout en tenant compte. entre autres, de la hauteur du pont des embarcations à partir de la ligne de flottaison correspondant au tirant d'eau en eau de mer.

(i) Deux tireveilles doivent être attachées aux extrémités des bossoirs et les garants et ces tireveilles doivent être assez longs pour atteindre l'eau lorsque le navire est à son tirant d'eau minimum à la mer et a une bande de $15^{\circ}$ d'un bord quelconque. Les poulies inférieures doivent être munies d'un anneau ou d'une maille allongée disposés pour être passés dans les crocs de suspente. à moins que ne soit installé un dispositif d'échappement d'un modèle approuvé.

(j) Les embarcations de sauvetage attachées aux bossoirs doivent avoir leur palans prêts à être utilisés et des dispositions doivent être prises pour que les embarcations de sauvetage soient rapidement libérées des palans, sans qu'il soit nécessaire que cette manœuvre soit simultanée pour les deux palans. Les points d'attache des embarcations de sauvetage aux palans seront placés Je telle sorte que les embarcations de sauvetage puissent être facilement dégagées des bossoirs.

\section{Règle 34}

\section{Nombre de Bouées de Sanverage}

(a) On doit mettre à bord au moins 8 bouées de sauvetage approuvées d'un type qui satisfasse aux exigences de la Règle 16 . Toutes les bouées de sauvetage seront munies de guirlandes solidement amarrées.

(b) Au moins la moitié des bouées de sauvetage doivent être munies d'appareils à éclairage automatique d'un type approuvé. ne devant pas s'éteindre par l'effet de l'eau. Ces appareils doivent ĉtre disposés près des bouées auxquelles ils appartiennent. avec les dispositifs d'attache nécessaires.

Il doit y avoir une bouée au moins, de chaque bord. qui soit pourvue a'une ligne de sauvetage longue de $27,50 \mathrm{~m}$. (ou 15 brasses) au moins.

(c) Dans le cas de navires-citernes les appareils automatiques d'éclairage doivent être du type à batterie électrique. 


\section{CHAPTER IV.-RADIOTELEGRAPHY AND RADIOTELEPHONY}

\section{PART A.-APPLICATION AND DEFINITIONS}

\section{Regulation 1}

\section{Application}

(a) Unless expressly provided otherwise, this Chapter applies to all ships to which the present Convention applies.

(b) No provision in this Chapter shall prevent the use by a ship or survival craft in distress of any means at its disposal to attract attention, make known its position and obtain help.

\section{Regulation 2}

\section{Definitions}

For the purpose of this Chapter. unless expressly provided otherwise-

(a) "Radio Regulations" means tbe General Radiocommunication Regulations annexed to the International Telecommunication Convention (Madrid, 1932) or any regulations which have been, or which from time to time in the future may be, substituted for such regulations.

(b) "Alarm Signal" means the automatic alarm sigoal prescribed by the Radio Regulations for radiotelegraphy.

(c) "Auto Alarm" means an automatic alarm receiver which responds to the alarm signal and has been approved.

(d) "Distress frequencies" means the distress frequencies designated for radiotelegraphy and radiotelephony respectively by the Radio Regulations."

(e) "Distress Signal" means a distress signal prescribed by the Radio Regulations.

(f) "Qualified Operator" means a person holding an appropriate certifcate complying with the provisions of the Radio Regulations.

(g) An existing installation is one already installed on board a ship at the time the present Convention comes into force.

(h) A new installation is an installation which replaces an existing installation or one installed on a ship after the date on which the present Convention comes into force.

\section{Regulation 3}

\section{Radiotelegraph Installation}

Passenger ships irrespective of size and cargo ships of 1,600 tons gross tonnage and upwards, unless exempted under Regulation 5 , shall be fitted with a radiotelegraph installation complying with the provisions of Regula. tions 9 and 10 .

- Note.-The frequencies prescribed at the present time are $500 \mathrm{kc} / \mathrm{s}$ (Radiotelegraphy) and, when the Radio Regulations annexed to the Intennational Telocommunication Convention (Atlantic City. 1947) come into force, $2.182 \mathrm{kc} / \mathrm{s}$ (Radiotelepbony). 


\section{CHAPITRE IV.-RADIOTELEGRAPHIE ET RADIOTELEPHONIE}

\section{PARTIE A.-APPLICATION ET DEFINITIONS}

\section{Règle 1}

\section{Application}

(a) Le présent Chapitre, à moins de dispositions expresses contraires, s'applique à tous les navires auxquels s'applique la Convention.

(b) Aucune disposition de ce Chapitre ne pourra einpécher un navire ou une embarcation rescapée d'employer tous les moyens disponibles pour atcirer l'attention, signaler sa position et obtenir du secours.

\section{Règle 2}

\section{Définisions}

Pour l'application du présent Chapitre, à moins de dispositions expresses contraires-

(a) L'expression "Règlement des Radiocommunications " désigne le Règlement général des Radiocornmunications annexé à la Convention Internationale des Télécommunications (Madrid 1932) ou tout règlement qui y a été substitué. ou qui pourra y être substitué dans l'avenir à un moment quelconque.

(b) L'expression "Signal d'Alarme" désigne le signal d'alarme automatique prescrit par le Règlement des Radiocommunications relatif à la Radiotélégraphie.

(c) L'expression "Auto-Alarme" désigne un appareil automatique d'alarme qui est déclanché par le signal d'alarme, et aura été approuvé par l'Administration.

(d) L'expression "Fréquences de détresse" désigne les fréquences respectiveınent assignées à la Radiotélégraphie et à la Radiotéléphonie par le Règlement des Radiocommunications."

(e) L'expression "Signal de détresse" désigne un signal de détresse prescrit par le Règlement des Radiocommunications.

$(f)$ L'expression "Opérateur qualifié" désigne une personne possédant le certificat requis conformément aux dispositions du Règlement des Radiocommunications.

(g) Une installation existante est une installation déjà en place au moment de l'entrée en vigueur de la présente Convention.

(h) Une installation nouvelle est une installation qui remplacera une installation existante ou qui sera installée sur un navire aprés l'entrée en vigueur de la présente Convention.

\section{Règle 3 \\ Installations radiotélégraphiques}

Les navires à passagers, quelle que soit leur dimension, et les navires de charge d'une jauge brute égale ou supérieure à 1.600 tonneaux doivent, à moins qu'ils n'en soient exemptés par la Règle 5, être pourvus d'une installation radiotélégraphique conforme aux dispositions des Règles 9 et 10.

* N.B. - La fréquence prescrite est actuellement de 500 kcs. Radiotélégraphie. Elle sera de 2,182 kcs. en Radiotéléphonie lorsque le Rèlement des Radiocommunications (Atlantic City. 1947) entrera en vigueur. 


\section{Regulation 4}

\section{Radiorelephone Installation}

Cargo ships of 500 tons gross tonnage and upwards but less than 1.600 tons gross tonnage, unless fitted with a radiotelegraph installation complying with the provisions of Regulations 9 and 10, shall, provided they are not exempted under Regulation 6 . be fitted with a radiotelephone installation complying with the provisions of Regulation 15.

\section{Regulation 5}

\section{Exemptions from Regulasion 3}

(a) The Contracting Governments consider it highly desirable not to deviate from the application of Regulation 3, nevertheless each Administration may grant to individual passenger and cargo ships belonging to its country exemptions of a partial and/or conditional nature, or complete exemption from the requirements of Regulation 3.

(b) The exemptions permitted under paragraph (a) of this Regulation shall be granted only to a ship engaged on a voyage where the maximum distance of the ship from the shore. the length of the voyage, the absence of general navigational hazards, and other conditions affecting safety are such as to render the full application of Regulation 3 unreasonable or unnecessary.

(c) Each Administration shall submit to the Organisation as soon as possible after the first of January in each year a report showing all exemptions granted under sub-paragraphs $(a)$ and $(b)$ of this Regulation during the previous calendar year.

\section{Regulation 6}

\section{Exemptions from Regulasion 4}

Each Administration may, if it considers that the route and conditions of the voyage are such as to render a radiotelephone installation unreasonahle or unnecessary, exempt ships belonging to its country from the requirements of Regulation 4.

\section{PART B.-WATCHES \\ Regulation 7 \\ Watches-Radiotelegraph}

(a) (i) Each ship which in accordance with Regulation 3 is required to to be fitted with a radiotelegraph installation shall, while at sea, carry at least one qualified operator* and, if not fitted with an auto alarm, shall. subject to the provisions of paragraph (d) of this Regulation, listen continuously on the radiotelegraph distress frequency in the medium frequency band by means of a qualified operator using some aural method.

(ii) However, in order to permit the installation of auto alarms developed in accordance with the specification in Regulation 11 in existing passenger ships below 3,000 tons gross tonnage and existing cargo ships below 5.500 tons gross tonnage, not fitted with an auto alarm. Administrations may on such ships permit the hours of listening to he limited to those shewn in paragraphs (b)

\footnotetext{
- NotE.-In some countries called radio officer.
} 


\section{Règle 4}

\section{Installations radiotéléphoniques}

Les navires de charge d'une jauge brute égale ou supérieure à 500 tonneaux, mais inférieure à 1.600 tonneaux. à moins d'être pourvus d'une installation radiotélégraphique, conformément aux dispositions des Règles 9 et 10, doivent. s'ils n'en sont pas exemptés aux termes de la Règle 6, être pourvus d'une installation radiotéléphonique conformément aux dispositions de la Règle 15.

\section{Règle 5}

\section{Exemprion des Prescriptions de la Règle 3}

(a) Les Gouvermements Contractants estiment qu'il est particulièrement indiqué de ne pas s'écarter des dispositions de la Règle 3; cependant chaque Administration aura le droit d'accorder à certains navires à passagers et à certains navires de charge apparienant à son pays, des exemptions de caractère partiel et/ou conditionnel, ou même une excmption totale des prescriptions de la Règle 3.

(b) Les exemptions accordées en vertu du paragraphe (a) de la présente Règle ne seront accordées qu'à des navires effectuant un voyage au cours duquel la distance maxima à laquelle le navire s'éloignera de la cóte. la longueur du voyage, l'absence des risques habituels de la navigation et autres conditions affectant la sécurité sont telles que l'application intégrale de la Règle 3 n'est ni raisonnable ni nécessaire.

(c) Chaque Administration soumettra à l'Organisation, dès que possible, après le ler janvier de chaque année un rapport indiquant toutes les exemptions accordées en vertu des alinéas $(a)$ et $(b)$ de la présente Règle, au cours de l'année civile précédente.

\section{Règle 6}

\section{Exemption des Prescriptions de la Règle 4}

Toute Administration peut. si elle estime que la route suivie et les conditions du voyage sont telles qu'une installation radiotéléphonique n'est ni raisonnable ni nécessaire. exempter des navires appartenant à son pavs des prescriptions de la Règle 4.

\section{PARTIE B.-SERVICES D'ÉCOUTE}

\section{Règle 7}

\section{Services d'écoute radiotélégraphiques}

(a) (i) Tout navire qui, conformément aux dispositions de la Règle 3. doit être obligatoirement pourvu d'une installation radiotélégraphique, doit avoir à bord, lorsqu'il est à la mer, au moins un opérateur qualifiét et, s'il n'est pas muni d'un auto-alarme, doit. sous réserve des dispositions du paragraphe (d) de la présente Règle, assurer un service d'écoute permanent sur la fréquence de détresse radiotélégraphique dans la bande des fréquences moyennes, au moyen d'un opérateur qualifié effectuant la veille à l'écoute.

(ii) Cependant en vue de permettre l'installation d'auto-alurmes réalisés conformément à la nouvelle spécification contenue dans la Règle 11 les Administrations pourront permettre que les heures d'écoute soient limitecs à celles prévues aux paragraphes $(b)$ et $(c)$ (i) de la présente Règle pendant une période n'excédant pas deux ans à partir de la mise en vigueur de la

$\uparrow$ N.B.-Appelé dans certains pays: officier-radiotélégraphiste. 
and (c) (i) of this Regulation for a period not exceeding two years from the date of coming into force of the present Convention.

\section{Passenger Ships}

(b) Each passenger ship which in accordance with Regulation 3 is required to be fitted with a radiotelegraph installation, if fitted with an auto alarm shall. subject to the provisions of paragraph (d) of this Regulation, and while at sea, listen on the radiotelegraph distress frequency in the medium frequency band by means of a qualified operator using some aural method, as follows:-

(i) if carrying or certificated to carry 250 passengers or less, at least 8 hours listening a day in the aggregate;

(ii) if carrying or certificated to carry more than 250 passengers and engaged on a voyage exceeding 16 hours duration between two consecutive ports, at least 16 hours listening a day in the aggregate. In this case the ship shall carry at least two qualified operators:

(iii) if carrying or certificated to carry more than 250 passengers and engaged on a voyage of less than 16 hours duration between two consecutive ports, at least $\mathbf{8}$ hours listening a day in the aggregatc.

\section{Cargo Ships}

(c) (i) Each cargo ship which in accordance with Regulation 3 is required to be fitted with a radiotelegraph installation, if fitted with an auto alarm shall, subject to the provisions of paragraph (d) of this Regulation and. while at sea, listen on the radiotelegraph distress frequency in tbe medium frequency band by means of a qualified operator using some aural method. as follows :-

(a) if of 5.500 tons gross tonnage and upwards. for at least 8 hours a day in the aggregate;

(b) if of 1,600 tons gross tonnage and upwards but less than 5,500 tons gross tonnage for at least 8 hours a day in the aggregate. Administrations which on account of their special conditions find it impracticable to impose 8 hours listening shall take steps to ensure the maximum hours of listening possible and not less than 2 hours a day in the aggregate.*

(ii) Each cargo ship of 500 tons gross tonnage and upwards but less than 1.600 tons gross tonnage and fitted with a radiotelegraph installation as a consequence of Regulation 4, shall carry at least one qualified operator and shall, subject to the provisions of paragraph (d) of this Regulation, and while at sea, listen on the radiotelegraph distress frequency in the medium frequency band, by means of a qualified operator using some aural method. during such periods as may be determined by the Administration.

(d) During the period when a qualified operator is required by this Regulation to listen on the distress frequency the operator may discontinue

* Note: The Netherlands Administration find it impracticable to comply entirely with this sub-paragraph, in respect of cargo ships of 1,600 tons gross tonnage and upwards but less than 3,500 tons gross tonnage. Nevertheless this Administration agrces to take steps to ensure the maximum possible hours of listening in sucb ships. 
présente Convention, sur les navires à passagers existants de moins de 3000 tonneaux et sur les navires de charge existants de moins de 5500 tonneaux, qui ne seraient pas déjà pourvus d'un auto-alanne.

\section{Navires à passagers}

(b) Tout navire à passagers qui doit être obligatoirement muni d'une installation radiotélégraphique en vertu de la Règle 3 doit s'il est pourvu d'un auto-alarme, sous réserve des dispositions figurant au paragraphe $(d)$ de la présente Règle et tant qu'il est à la mer, assurer un service d'écoute sur la fréquence de détresse radiotélégraphique dans la bande des fréquences moyennes, au moyen d'un opérateur qualifié effectuant la veille à l'écoute dans les conditions suivantes:-

(i) s`il transporte ou est autorisé à transporter jusqu’à 250 passagers, un total d'au moins 8 beures d'écoute par jour:

(ii) s'il transporte ou est autorisé à transporter plus de 250 passagers et s'il effectue un voyage entre deux ports consécutifs dont la durée dépasse 16 heures, un total d'au moins 16 heures d'écoute par jour. Dans ce cas le navire devra avoir à bord au moins deux opérateurs qualifiés;

(iii) s'il transporte ou est autorisé à transporter plus de 250 passagers et s'il effectue un voyage entre deux ports consécutifs d'une durée de moins de 16 heures, un total d'au moins 8 heures d'écoute par jour.

\section{Navires de charge}

(c) (i) Tout navire de charge qui, conformément à la Régle 3, doit être pourvu d'une installation radiotélégraphique, s'il est muni d'un auto-alarme, doit, sous réserve des dispositions du paragraphe $(d)$ de la présente Règle et lorsqu'il est à la mer. assurer un service d'écoute sur la fréquence de détresse radiotélégraphique, dans la bande des fréquences moyennes, au moj'en d'un opérateur qualifié effectuant la veille à l'écoute dans les conditions suivantes:-

(a) à bord des navires d'une jauge brute égale ou supérieure à 5500 tonneaux, pendant au moins 8 heures par jour au total;

(b) à bord des navires d'une jauge brute égale ou supérieure à 1600 tonneaux mais inférieure à 5500 tonneaux, pendant au moins huit heures par jour au total. Les Administrations qui, en raison de conditions qui leur sont particulières, se trouvent dans l'impossibilité d'imposer un service d'écoute de 8 heures devront prendre des dispositions pour assurer le nombre maximum possible d'heures d'écoute, qui ne sera pas inférieur à 2 heures par jour au total.(*)

(ii) Tout navire de charge d'une jauge brute égale ou supérieure à 500 tonneaux mais inférieure à 1600 tonneaux, pourvu d'une installation radio. télégraphique par application de la Règle 4, doit avoir à bord au moins un opérateur qualifé et doit, sous réserve des dispositions du paragraphe $(d)$ de la présente Règle et lorsqu'il est à la mer, assurer un service d'écoute sur la fréquence de détresse radiotélégraphique, dans la bande des fréquences moyennes, au moyen d'un opérateur qualifié faisant la veille à l'écoute, pen. dant les périodes qui pourront être prescrites par l'Administration.

(d) Aux heures où un opérateur qualifié devra, en vertu de la présente Règle, écouter sur la fréquence de détresse, cet opérateur pourra interrompre

* N.B.-L'Administration des Pays-Bas estime pratiquement impossible de se conformer entièrement aux termes de cet alinéa, en ce qui concerne les navires de charge de 1,600 conneaux de jauge brute el au-dessus, et de moins de 3,500 conneaux de jauge brule. Néanmoins, cette Administration est d'accord pour prendre des mesures destinées à assurer le nombre maximum possible d'heures d'écoute à bord de ces navires. 
such listening during the time when he is handling traffic on other frequencies, or performing other essential radio duties, but only if it is impracticable to listen by some aural means such as split headphones or loud speaker. When this aural listening is impracticable, the auto alarm if fitted shall be in operation. The provisions of this paragraph shall not relieve the ship from compliance with the provisions of the Radio Regulations in regard to the "silence periods".

(e) In all ships fitted with an auto alarm this auto alarm shall, while the ship is at sea, be in operation whenever there is no listening being done under paragraphs $(b) .(c)$ or $(d)$.

(f) The listening periods provided for by this Regulation, including those which are determined by the Administration. should be maintained preferably during periods prescribed for radiotelegraph service by the Radio Regulations.

\section{Regulation 8}

\section{Watches-Radiotelephone}

Each ship which is fitted with a radiotelephone installation in accordance with Regulation 4 shall, for safety purposes. carry at least one qualified operator (who nay be a member of the crew holding only a certificate for radiotelephony) and shall. while at sea. listen on the radiotelephone distress frequency in the medium frequency band during such periods as may be determined by the Administration.

\section{PART C.-TECHNICAL REQUIREMENTS \\ Regulation 9}

\section{Radiotelegraph Stations}

(a) The ship's radiotelegraph station sliall be so located that no harmful interference from extraneous mechanical or other noise will be caused to the proper reception of radio signals. The station shall be placed as high in the ship as is practicable, so that the greatest possible degree of safety may be secured.

(b) There shall be provided between the radiotelegraph operating room and the bridge and one other place. if any, from which the ship is navigated, an efficient two-way system for calling and voice communication which shall be independent of the nlain communication system on the ship.

(c) A reliable clock, equipped with a dial not less than 5 inches in diameter and provided with a concentric seconds hand. shall be securely mounted in the radiotelegraph operating room in such a position that the entire dial can be easily and accurately observed by the operator from the telegraph operating position and the auto alarm testing position.

(d) A reliable emergency light shall be provided in the radiotelegraph operating room permanently arranged so as to provide satisfactory illumination of the operating controls of the main and emergency radiotelegraph installations and of the clock required by paragraph (c) of this Regulation.

(e) If a separate emergency radiotelegraph operating room is provided the requirements of paragraphs $(b)$. (c) and (d) shall apply to it.

(f) The ship's radiotelegraph station shall be provided with such spare parts. tools and testing equipment as will enable the radiotelegraph installation to be maintained in efficient working condition while at sea. 
ce service. lorsqu'il assurera le service du trafic sur d’autres fréquences, ou accomplira d'autres fonctions essentielles relatives à la Radio ; il ne pourra le faire que si en pratique il lui est impossible d'assurer l'écoute par quelque autre moyen, tels que: casque à deux branchements ou haut-parleur. Si cette veille à l'écoute est impossible dans la pratique, l'auto-alarme, s'il y en a un à bord, devra être mis en service. Les dispositions du présent paragraphe ne dispensent pas le navire de se conformer aux dispositions du Règlement des Radiocommunications relatives " aux périodes de silence."

(e) A bord de tous les navires munis d'un auto-alarme, cet auto-alarme devra, lorsque le navire est à la mer, être mis en service à tous les moments où il ne sera pas effectué de veille en vertu du paragraphe (b). (c) ou (d).

(f) Les périodes d'écoute prévues par la présente Règle, y compris celles fixées par l'Administration. devront être observées de préférence aux heures fixées par le Règlement des Radiocommunications pour la service radiotélégraphique.

\section{Règle 8}

\section{Service d'Écoute-Radiotéléphonie}

Tout navire muni dune installation radiotéléphonique, conformément à la Règle 4, doit, pour des raisons de sécurité, avoir à bord au moins un opérateur qualifié (qui pourra être un membre de l'équipage ne possédant qu'un certificat de Radiotéléphoniste) et assurer, lorsqu'il est à la mer, un service d’écoute sur la fréquence de détresse radiotéléphonique, dans la bande des fréquences moyennes, pendant les périodes qui pourront ètre tixées par l'Administration.

\section{PARTIE C.-CONDITIONS TECHNIQUES REQUISES}

\section{Règle 9}

\section{Stations de Radiotélégraphie}

(a) La station de radiotélégraphie doit ètre placée de telle manière qu'aucun brouillage nuisible provenant d'un bruit extérieur, d'origine mécanique ou autre, n'empêche une réception convenable des signaux radiotélégraphiques. La station doit étre placée aussi haut que possible sur le navire afin d'assurer la plus grande sécurité possible.

(b) On doit prévoir entre la cabine de radiotélégraphie et la passerelle et un autre endroit, s'il en existe, d'où l'on dirige le navire, une liaison bilatérale. efficace pour appeler et converser, qui doit être indépendante du réseau principal du navire.

(c) Une pendule d'un fonctionnement súr dont le diamètre de cadran ne sera pas inférieur à $12.5 \mathrm{~cm}$ (ou 5 pouces), munie d'une aiguille centrale battant la seconde, sera solidement fixée dans la cabine de radiotélégraphie. Sa position doit être telle que le cadran entier puisse être observé facilement et avec précision par l'opérateur, de la position de travail télégraphique et de la position d'essai de l'auto-alarme.

(d) La cabine de radiotélégraphie doit avoir un éclairage de secours d'un fonctionnement sûr, installé en permanence de façon à foumir un éclairage satisfaisant des appareils de commande et de contrôle des installations principales et de secours ainsi que de la pendule exigée par le paragraphe $(c)$ de la présente Règle.

(e) S'il existe une cabine de radiotélégraphie de secours distincte, elle doit être soumise aux dispositions des paragraphes $(b)$. (c) et (d).

(f) La station de radiotélégraphie du navire doit être pourvue des pièces de rechange, de l'outillage et des appareils de contrôle nécessaires pour maintenir en bonne condition de fonctionnement l'installation radio. télégraphique pendant que le navire est à la mer.

43055 


\section{Regulation 10}

\section{Rudiorelegraph Installations}

(a) Except as otherwise expressly provided in this Regulation-

(i) The radiotelegraph installation shall comprise a main installation and an emergency (reserve) installation, electrically separate and electrically independent of each other.

(ii) A main and an emergency aerial shall be provided and installed. provided that the Administration may except any ship from the provision of an emergency aerial if it is satisfied that the fitting of such an aerial is impracticable or unreasonable, but in such case a spare aerial completely assembled for immediate replacement shall be carried.

The main aerial shall be suitably protected against breakage caused by whipping of the mast or masts.

(iii) The main installation shall include a main transmitter, main receiver. and main source of energy.

(iv) The emergency (reserve) installation shall include an emergency transmitter, emergency receiver, and emergency source of energy.

(b) In the case of existing installations on passenger ships the application of the requirement for a separate emergency transmitter and a separate emergency source of energy may, if the main transmitter and main source of energy comply with all the requirements for the emergency transmitter and emergency source of energy as defined in this Regulation, be delayed for a period not exceeding three years from the coming into force of the present Convention.

(c) In the case of-

(i) existing installations on cargo ships. and

(ii) new installations on cargo ships of 500 tons gross tonnage and upwards but less than 1,600 tons gross tonnage,

if the main transmitter and main source of energy comply with all the requirements for the emergency transmitter and the emergency source of energy, the latter are not obligatory.

(d) The main and emergency (reserve) installations shall be capable of being quickly connected with either the main aerial or the emergency aerial if installed.

(e) All parts of the emergency (reserve) installation shall be placed as high in the ship as is practicable so that the greatest possible degree of safety may be secured.

(f) The main and emergency (reserve) transmitters shall be capable of transmitting on the radiotelegraph frequency, and of using a class of emission, assigned by the Radio Regulations for the purpose of distress in the medium frequency band, and shall have a depth of modulation of not less than 70 per cent. In addition, the main transmitter shall be capable of transmitting on the frequencies, and of using a class of emission, assigned by the Radio Regulations for the purpose of safety of navigation in the medium frequency band.

(g) In new installations the main and emergency (reserve) transmitters shall have a note frequency of more than 450 and less than 1.350 cycles per second. 


\section{Règle 10}

\section{Installations radiotélégraphiques}

(a) Sauf dispositions expresses contraires de la présente Règle:

(i) L'installation radiotélégraphique doit comprendre une inslallation principale et une installation de secours (réserve), électriquement séparées et électriquement indépendantes l'une de l'autre.

(ii) Un aérien principal et un aérien de secours doivent être prévus et installés, étant entendu toutefois que l'Administration peut exempter tout navire des prescriptions relatives à l'aérien de secours si elle considère que l'installation de cet aérien n'est ni praticable ni raisonnable. Mais en ce cas on doit prévoir à bord un aérien de secours cornplètement assemblé, en vue d'un remplace. ment immédiat.

L'aérien principal doit être correctement protégé d'une rupture causée par les vibrations du ou des mâts.

(iii) L'installation principale doit comprendre un émetteur principal, un récepteur principal et une source principale d'énergie.

(iv) L'installation de secours (réserve) doit comprendre un émetteur de sccours, un récepteur de secours et une source d'ćnergie de secours.

(b) Pour les installations existantes sur les navires à passagers et dans le cas où l'émetteur principal et la source d’énergie principale remplissent toutes les conditions requises de l'émetteur de secours et de la source d'énergie de secours, tels qu'ils sont définis dans la présente Règle, l'application de la prescription concernant l'existence d'un émetteur de secours séparé et d'une source d'énergie de secours séparée peut être différée pendant une période n'excédant pas trois ans à partir de la mise en vigueur de la présente Convention.

(c) En ce qui concerne:

(i) les installations existantes sur les navires de charge.

(ii) les installations nouvelles sur les navires de charge d'une jauge brute égale ou supérieure à 500 tonneaux mais inférieure à 1.600 tonneaux,

si l'émetteur principal et la source d'énergie principale remplissent toutes les conditions requises pour l'émetteur de secours et pour la source d'énergie de secours, ces derniers ne sont pas obligatoires.

(d) Les installations principales et de secours doivent pouvoir être connectées rapidement soit avec l'aérien principal, soit avec l'aérien de secours. s'il en existe un.

(e) Tous les élćments de l'installation de secours (réserve) doivent être placés sur le navire aussi haut que possible pour assurer la plus grande sécurité possible.

(f) L'émetteur et l'émetteur de secours (réserve) doivent pouvoir ćmettre sur la fréquence radiotélégraphique, et utiliser une classe d'émission. assignées par le Règlement des Radiocommunications, dans la bande des fréquences moyennes, aux besoins de la détresse et doivent avoir un taux de modulation d'au moins 70 pour cent. De plus, l'émetteur principal doit pouvoir émettre sur les fréquences et utiliser une classe d'émission assignées par le Règlement des Radiocommunications, dans la bande des fréquences moyennes, aux besoins de la sécurité de la navigation.

(g) Dans les installations nouvelles, l'émetteur principal et l'émetteur de secours (réserve) doivent avoir une fréquence de modulation supérieure à 450 et inférieure à 1,350 cycles par seconde. 
(h) The main and emergency (reserve) transmitters shall have a minimum normal range as specified below, that is to say. they must be capable of transmitting clearly perceptible signals from ship to ship by day and under normal conditions and circumstances over the specified ranges.* (Clearly perceptible signals will normally be received if the R.M.S. value of the field strength at the receiver is at least 50 miciovolts per metre.)

\begin{tabular}{l|c|c|}
\hline \multirow{2}{*}{} & \multicolumn{2}{|c|}{ Minimum normal range in miles } \\
\cline { 2 - 3 } & $\begin{array}{c}\text { Main } \\
\text { transmitter }\end{array}$ & $\begin{array}{c}\text { Emergency } \\
\text { transmitter }\end{array}$ \\
\hline $\begin{array}{c}\text { All passenger ships, and cargo ships of } 1,600 \\
\text { tons gross tonnage and over } \ldots\end{array}$ & 150 & 100 \\
Cargo ships below 1,600 tons gross tonnage & 100 & 75 \\
\hline
\end{tabular}

(i) (i) The main and emergency receivers shall be capable of receiving the radiotclegraph frequency, and the classes of emission, assigned by the Radio Regulations for the purpose of distress in the medium frequency band.

(ii) In addition, the main receiver shall permit of the reception of such of the frequencies and classes of emission used for the transmission of time signals, meteorological messages and such other communications relating to safety of navigation as may be considered necessary by the Administration.

(iii) The auto alarm receiver may be used as the emergency receiver.

- In the absence of a direct measurement of the field strength the following data may be used as a guide for approximately determining the nornal range:-

\begin{tabular}{c|c|c}
\hline Normal range in miles & Metre-amperest & $\begin{array}{c}\text { Total aerial } \\
\text { power (watts) } \$\end{array}$ \\
\hline 200 & 128 & 200 \\
175 & 102 & 125 \\
150 & 76 & 71 \\
125 & 58 & 41 \\
100 & 45 & 14 \\
75 & 34 & 14 \\
\hline
\end{tabular}

+ This figure represents the product of the maximum height of the aerial above the deepest load water line in metres and the aerial current in amperes (R.M.S. value).

The values given in the second column of the table correspond to an average value of the ratio

$$
\frac{\text { effective aerial height }}{\text { maximum aerial height }}=0.47
$$

This ratio varies with local conditions of the aerial and may vary betwoen about 0.3 and 0.7 .

\pm The values given in the third column of the table correspond to an average value of the ratio

$$
\frac{\text { radiated aerial power }}{\text { total aerial power }}=0.08
$$

This ratio varies considerably according to the values of effective aerial height and aerial resistance. 
(h) Les émetteurs principal et de secours (réserve) doivent avoir une portée normale minimum telle qu'elle est spécifiée ci-dessous, c'est-à-dire qu'ils doivent pouvoir transmettre aux distances spécifiées des signaux clairement perceptibles de navire à navire, de jour, et dans des conditions et des circonstances normales. * (Des signaux clairement perceptibles doivent normalement pouvoir être reçus si la valeur efficace de l'intensité de champ au récepteur est au moins de 50 microvolts par mètre.)

Portèe minimum normale en milles marins

Tous navires à passagers, et navires de charge de J,600 conneaux et au-dessus

Emetteur
principal

Navires de charge de moins de 1,600 tonneaux

(i) (i) Le récepteur principal et le récepteur de secours doivent pouvoir recevoir sur la fręquence radiotélégraphique et dans les classes d'émissions assignées par le Règlement des Radiocommunications. dans la bande des fréquences moyennes, aux besoins de la détresse.

(ii) En outre. le récepteur principal doit permettre la réception des fréquences et des classes d'émissions utilisées pour la transmission des signaux horaires. des messages météorologiques et de toutes autres communications relatives à la sécurité de la navigation que l’Administration peut considérer comme nécessaires.

(iii) Le récepteur de l'auto-alarme peut tenir lieu de récepteur de secours.

* En l'absence d'une mesure directe de l'intensité de champ, les données suivantes peuvent servir de guide pour déterminer approximativement la portée normale:

\begin{tabular}{c|c|c}
\hline $\begin{array}{c}\text { Portée normale } \\
\text { en milles marins }\end{array}$ & Mètres-Ampèrest & $\begin{array}{c}\text { Puissance totale dans } \\
\text { I'árien (watts): }\end{array}$ \\
\hline & & \\
200 & 128 & 200 \\
175 & 102 & 125 \\
150 & 76 & 71 \\
125 & 58 & 41 \\
100 & 45 & 25 \\
75 & 34 & 14 \\
\hline
\end{tabular}

† Ce nombre représente le produit de la hauteur maximum, exprimée en mètres, de l'aérien au-dessus de la ligne de charge maximum par le courant de laérien exprimé en ampères (valeur efficace).

Les valeurs données dans la table (colonne 2 ) correspondent à une valeur moyenne du rapport:

$$
\frac{\text { hauteur effoctive d'aérien }}{\text { hauteur maximum d'aérien }}=0,47
$$
environ.

Ce rapport varie avec les conditions locales de l'aérien et peut varier entre 0,3 et 0,7

$\$$ Les valeurs données par le tableau (colonne 3 ) correspondent a une valeur moyenne du rapport:

$$
\frac{\text { puissance rayonnée par l'aérien }}{\text { puissance totale dans l'aérien }}=0,08
$$

Ce rapport varie considérablement suivant les valeurs de la hauteur effective et de lad résistance de l'aérien. 
(i) The main receiver shall have sufticient sensitivity to produce signals in headphones or by means of a loudspeaker when the receiver input is as low as 100 inicrovolts. The emergency receiver shall have the same sensitivity except in cases where an approved auto alarm is used as the emergency receiver.

(k) There shall be available at all times, while the ship is at sea, a supply of electrical power sufficient for operating the main installation over the normal range required by paragraph $(h)$ of this Regulation as well as for the purpose of charging any batteries forming part of the radiotelegraph installation. The voltage of the supply for the main installation shall be maintained as near the rated voltage as possible, and if practicable within \pm 10 per cent.

(l) The emergency (reserve) installation shall be provided with a source of energy independent of the propelling power of the ship and of the ship's electricity system. The source of energy shall preferably consist of accumulator batteries and shall under all circumstances be capable of being put into operation rapidly and of operating the emergency (reserve) transmitter and receiver for at least six hours continuously under normal working conditions besides any of the additional loads mentioned below.

(m) The emergency source of energy may be used only to supply :

(i) the emergency installation and the automatic alarm signal keying device specitied in paragraph $(s)$ of this Regulation;

(ii) the emergency light specitied in paragraph (d) of Regulation 9:

(iii) the auto alarm: and

(iv) the direction tinder.

(n) Notwithstanding the provisions of paragraph (m) of this Regulation. in cargo ships, an Administration may authorise the use of the emergency source of energy for a small number of low-power emergency circuits which are wholly contined to the upper part of the ship. sucb as emergency lighting on the boat deck, on condition that these can be readily disconnected if necessary.

(o) The emergency source of energy and its switchboard shall be readily accessible to the radio operator and shall wherever possible be placed in close proximity to a radio room.

(p) While the ship is a sea. accumulator batteries, whether forming part of the main installation or emergency (reserve) installation, shall be brought up to the normal fully-charged condition daily.

(q) The radiotelegraph installation shall be provided with a device permitting changeover from transmission to reception and vice versa without manual switching. The application of this requirement may be delayed for one year after the date of the coming into force of the present Convention.

( $r$ ) All steps shall be taken to eliminate so far as is possible the causes of, and to suppress, radio interference from electrical and other apparatus on board.

(s) In addition to means for manually transmitting the auto alarm signal, an automatic alarm signal keying device shall be provided, capable of automatically keying the main and the emergency (reserve) installation so as to transmit the alarm signal. If electrically operated, this keying device shall be capable of operation from the emergency power supply. The application of this requirement may be delayed for two years after the date of the coming into force of the present Convention. 
(6) Le récepteur principal doit avoir une sensibilité suffisante pour donner des signaux dans les écouteurs ou dans un haut-parleur. même lorsque la tension d'e ntrée du récepteur n'est que de 100 nuicrovolts. Le récepteur de secours doil avoir la même sensibilité excepté dans les cas où un système agréé d’auto-alarme est utilisé conme récepteur de secours.

(k) Une alimentation d'énergie électrique, suffisante pour faire fonctionner l'installation principale, à la portée normale requise par le paragraphe $(h)$ de la présente Règle aussi bien que pour charger toutes les batteries d'accumulateurs faisant partie de l'installation radiotélégraphique, doit être disponible à tout moment pendant que le navire est à la mer. La tension de l'alimentation de l'installation principale doit être maintenue aussi près que possible de la tension normale, et si possible à \pm 10 pour cent près.

(l) L'installation de secours (réserve) doit ètre munie d'une source d'énergie indépendante de celle de la puissance propulsive du navire et de son réseau électrique. Cette source doit être constituée de préférence par des batteries d'accumulateurs et doit en toutes circonstances pouvoir être mise en marche rapidement et faire fonctionner l'émetteur et le récepteur de secours (réserve) dans des conditions normales d'exploitation, pendant au moins six heures consécutives. et. en outre. toutes les autres charges supplémentaires mentionnées plus bas.

(m) La source d’énergie de secours ne doit être utilisée que pour alimenter:

(i) linstallation de secours et le dispositif de manipulation automatique du signal d’alarme spícifié au paragraphe $(s)$ de la présente Règle;

(ii) l'éclairage du signal d’alarme spécifie au paragraphe (d) de la Règle 9:

(iii) l'auto-alarme; et

(iv) le radiogoniomètre.

(n) Nonobstant les prescriptions du paragraphe $(m)$ de la présente Règle. une Administration peut, en ce qui concerne les navires de charge. autoriser l'usage de la source d'énergie de secours pour alimenter un petit nombre de circuits de secours de faible puissance entièrement localisés à la partie supérieure du navire. à la condition que ces circuits puissent être facilement coupés, si nécessaire.

(o) La source d'énergie de secours et son tableau de distribution doivent être facilement accessibles à l'opérateur de radiotélégraphie et doivent, quand cela est possible, se trouver dans le voisinage immédiat de la cabine de radiotélégraphie.

(p) Pendant que le navire est à la mer, les batteries d'accumulateurs, qu'elles fassent partie de l'installation principale ou de l'installation de secours (róserve). doivent être chaque jour chargées à pleine charge.

(q) L'installation radiotélégraphique doit être munie d'un dispositif permettant le passage de l'émission à la réception et vice-versa sans commutation manuelle. L'application de cette prescription peut être différée pendant une annće à dater de la mise en vigueur de la présente Convention.

(r) On prendra toutes dispositions utiles pour éliminer autant que possible les causes de brouillage radioélectriques provenant des appareils électriques et des autres appareils du bord et pour supprimer ce brouillage.

(s) Pour émettre le signal d'alarme, on doit prévoir, outre les moyens d'émission manuelle. un appareil de manipulation automatique capable d'actionner l'installation principale et l'installation de secours (rćserve). Si ce dispositif de manipulation est commandé électriquement, il doit pouvoir fonctionner sur la source d'énergie de secours. L'application de cette prescription peut être différée pendant deux ans doter de la mise en vigueur de la présente Convention. 
(t) At sea, if not used for communications, the emergency transmitter shall be tested daily using a suitable artificial aerial, and at least once during each voyage using the emergency aerial if installed. The emergency power supply shall also be tested daily.

(11) Notwithstanding the provisions of Regulation 4, an Administration may, in the case of cargo ships below 1,600 tons gross tonnage, relax the full requirements of Regulation 9 and this Regulation, provided that the standard of the installation shall in no case fall below the equivalent of that prescribed under Regulation 15 for radiotelephone installations so far as applicable.

\section{Regulation 11 \\ Allio Alarms}

(a) Any new type of auto alarm which is approved after the date of coming into force of the present Convention for use in accordance with the present Regulations shall comply with the following minimum requirements:-

(i) In the absence of interference of any kind it must be capable of being operated, without manual adjustment, by any alarm signal transmitted on the radiotelegraph distress frequency in the medium frequency band using the classes of emission assigned by the Radio Regulations for the alarm signal, provided that the frequency does not vary more than $8 \mathrm{kc} / \mathrm{s}$ from the nominal frequency and the strength of the signal at the receiver input is greater than 100 microvolts and less than 1 volt.

(ii) In the absence of interference of any hind it shall be operated by either three or four consecutive dashes when the dashes vary in length from 3.5 to as near 6 seconds as possible and the spaces vary in length between 1.5 seconds and the lowest practicable value. preferably not greater than 10 milliseconds.

(iii) It must not be actuated by atmospherics or by any signal other than the alarm signal, provided that the received signals do not in fact constitute a signal falling within the tolerance limits indicated in (ii).

(iv) The selectivity of the auto alarm shall be such as to provide a practjcally uniform sensitivity within $8 \mathrm{kc} / \mathrm{s}$ on each side of the distress frequency and to provide outside this band a sensitivity which decreases as rapidly as possible. in conformity with the best engineering practice.

(v) If practicable, the auto alarm in the presence of atmospherics or interfering signals shall automatically adjust itself so that within a reasonably short time it approaches the condition in which it can most readily distinguish the alarm signal.

(vi) When operated by an alarm signal, or in the event of failure of the apparatus, the auto alarm shall cause a continuous audible waming to be given in the radiotelegraph operating room, in the radio operator's cabin, and on the bridge. If practicable, warning shall also be given in the case of failure of any part of the whole alarm receiving system. Only one switch for stopping the warning stall be provided and this shall be situated in the radiotelegraph operating room.

(vii) For the purpose of regularly testing the auto alarm, the apparatus shall include a generator pre-tuned to the distress frequency and a keying device by means of which an alarm signal of the minimum strength indicated in (i) is produced. 
( $t$ ) Pendant que le navire est à la nuer, l'émetteur de secours, s'il n'est pas utilisé pour les communications, doit être essayé chaque jour sur une antenne hictive convenable, et une fois au moins pendant chaque voyage sur l'aérien de secours s'il est monté. La source d'énergje de secours doit aussi être essayće chaque jour.

(u) Nonobstant les prescriptions du Règlement 4 une Administration peut, en ce qui concerne les navires de charge de moins de 1,600 tonneaux de jauge brute, admetre des atténuations à la Règle 9 et à la présente Régle, pourvu qu'en aucun cas la qualité de l'installation ne puisse être inférieure au niveau exigé par la Règle 15 pour les installations radiotéléphoniques. dans la mesure où cette Règle est applicable.

\section{Règle 11}

\section{Auro-Alurmes}

(a) Tout nouveau type d'auto-alarme qui sera approuvé aprés la date d'eatrée en vigueur de la présente Convention, pour être utilisé conformément à la présente Règle, devra répondre aux conditions minimum suivantes:

(i) En l'absence de brouillage de toute nature, il doit être mis en action, sans réglage manuel. par tout signal d'alarme transmis sur la fréquence radiotélégraphique de détresse en utilisant les classes d'émission assignées dans la bande des fréquences moyennes par le Règlement des Radiocommunications pour le signal d'alarme. pourvu que la fréquence ne s'écarte pas de plus de $8 \mathrm{kcs}$. de la fréquence nominale et que l'intensité du signal à l'entrée du récepteur soit supérieure à 100 microvolts et inférieure à 1 volt.

(ii) En l'absence de brouillage de toute nature il doit être actionné par trois ou quatre traits consécutifs quand la durée des traits varie de 3,5 secondes a une valeur aussi proche que possible de 6 secondes et quand la durée de l'intervalle varie entre 1,5 seconde et la plus petite valeur possible ne dépassant pas de préférence 10 milli. secondes.

(iii) Il ne doit pas être actionné par les atmosphériques ou par tout signal autre que le signal d'alarme pourvu que les signaux reçus ne constituent pas en fait un signal tombant dans les limites de tolérance indiquées en (ii).

(iv) La sélectivité de l'auto-alarme doit être telle qu'elle produise une sensibilité pratiquement uniforme dans une bande de $8 \mathrm{Kc} / \mathrm{s}$ de chaque côté de la fréquence de détresse et. en dehors de cette bande. une sensibilité décroissant aussi rapidement que possible, conformément aux meilleures règles de la technique.

(v) Si possible, l'auto-alarme en présence d'atmosphériques ou de brouillage, doit automatiquement se régler pour que, dans un délai raisonnablement court, il se rapproche des conditions dans lesquelles le signal d'alarme peut le plus facilement être distingué.

(vi) Quand l'appareil est actionné par un signal d'alarme ou de défaillance de l'appareil, l'auto-alarme doit produire un avertissement audible continu dans la cabine de radiotélégraphie, dans la cabine des opérateurs et sur la passerelle. Si possible, l'avertissement doit aussi être donné dans le cas d'une défaillance d'un élément quelconque du système récepteur d'alarme. Un seul interrupteur doit permettre de couper l'avertissement et cet interrupteur doit être placé dans la cabine de radiotélégraphie.

(vii) Aux fins d'essais périodiques de l'auto-alarme, l'appareil doit comprendre un générateur préalablement réglé sur la fréquence de détresse et un dispositif de manipulation pernettant de produire un signal d'alarme dont l'intensité minimum est indiquée en (i). 
(viii) The auto alarm shall be capable of witbstanding vibration, humidity, and changes of temperature, equivalent to severe conditions experienced on board ships at sea, and shall continue to operate under such conditions.

(b) Before a new type of auto alarm is approved the Administration concerned must be satisfied, by practical tests made under operating conditions equivalent to those obtaining in practice, that the apparatus complies with paragraph (a) of this Regulation.

(c) In ships fitted with an auto alarm the radio operator sball test the efficiency of the auto alarm at least once every 24 hours while at sea and report to the master or the officer on watch on the bridge whether or not it is in working order.

\section{Regulation 12}

\section{Direcsion finders}

(a) The direction-tinding apparalus required by Regulation 12 of Cbapter $\mathbf{V}$ shall he efficient and capable of receiving signals with the minimum of receiver noise and of taking bearings from which the true bearing and direction may be determined.

(b) It shall be capable of receiving signals on the medium frequencies assigned by the Radio Regulations for the purposes of distress and directionfinding and for maritime radio beacons.

(c) In the absence of interference the apparatus shall have a sensitivity sufficient to permit of accurate bearings being taken on a signal baving a field strength as low as 50 microvolts per metre.

(d) Efficient communication shall be provided between the directionfinding apparatus and the bridge.

(e) All direction finders shall be calibrated to the satisfaction of the Administration on first installation and the calibration shall be verified whenever any changes are made in the position of any aerials or of any structures on deck which might affect appreciably the accuracy of the direction finder. The calibration particulars shall be checked at yearly intervals, or as near thereto as possible. A record shall be kept of the calibrations and of any checks made of their accuracy.

\section{Regulation 13}

\section{Radio Equipment for forsing in Motor Lifeboass}

(a) The apparatus required by Regulation 25 of Chapter IU shall be capable of transmiting and receiving on the radiotelegraph frequency assigned by the Radio Regulations for the purpose of distress in the medium frequency band. The transmitter shall be capable of using a class of emission assigned by the Radio Regulations for the purpose of distress in the medium frequency band and shall be modulated to a deptb of at least 70 per cent. The receiver shall be capable of receiving the classes of emission assigned by the Radio Regulations for the purpose of distress in the medium frequency band. In new installations the apparatus shall also be capable of transmitting on the high frequency and the class of emission prescribed for survival craft by the Radio Regulations. An Administration may delay the application of the requirement for high frequency for a period not exceeding one year from the date of coming into force of the present Convention. 
(viii) L'auto-alarme doit pouvoir supporter des conditions de vibrations, d'humidité, et des variations de température équivalentes aux conditons sévères rencontrées à bord des navires à la mer, et doit continuer à fonctionner dans de telles conditions.

(b) Avant d'agréer un auto-alarme, l'Administration intéressée doit s'être assurée, par des essais pratiques faits dans des conditions de fonctionnement équivalentes à celles de la pratique, que l'appareil est conforme aux prescriptions du paragraphe $(a)$ de la présente Règle.

(c) Sur les navires munis d'un auto-alarnıe, l'opérateur de radiotélégraphie doit verifier l'efficacité de l'auto-alarme au moins une fois toutes les 24 heures pendant que le navire est à la mer et rendre compte au capitaine ou à l'officier de quart sur la passerelle si cet auto-alarme est ou non en ordre de marche.

\section{Règle 12}

\section{Radiogoniomètres}

(a) Le radiogoniomètre exigé par la Règie 12 du Chapitre $V$ doit être efficace et capable de recevoir des signaux avec le minimun! de bruit de rêcepteur et de prendre des relèvements à partir desquels le relèvement vrai et la direction pourront être déterminés.

(b) Il doit pouvoir recevoir des signaux sur les fréquences moyennes assignées par le Règlement des Radiocommunications pour les besoins de ta détresse et de la radiogoniométrie, ainsi qu'aux radiophares maritimes.

(c) En l'absence de brouillage, l'appareil doit avoir une sensibilité suffisante pour permettre de prendre des relèvements précis même sur un signal n'ayant que 50 microvolts par mètre d'intensité de champ.

(d) Un moyen de communication efficace doit être établi entre le radiogoniomètre et la passerelle.

(e) Tous les radiogoniomètres doivent être étalonnés lors de leur installation à la satisfaction de l'Administration et l'étalonnage doit être vérifié chaque fois que des modifications seront apportées à la position de tout aérien ou de toute structure sur le pont, qui pourraient affecter de manière appréciable l'exactitude du radiogoniomètre. Les caractéristiques de l'étalonnage doivent être vérifiées à des intervalles d'une année ou aussi rapprochés que possible d'une année. On tiendra un relevé de ces étalonnages et de toutes les vérifications de leur exactitude.

\section{Règle 13}

Equipement radiotélégraphique pour les Embarcations de Saunetage ì moreur

(a) Les appareils exigés par la Règle 25 du Chapitre III doivent pouvoir émettre et recevoir sur la fréquence radiotélégraphique assignée par le Règlement des Radiocommunications, dans la bande des fréquences moyennes. aux besoins de la détresse. L'émetteur doit être capable d'utiliser une classe d'émission assignée aux besoins de la détresse, dans la bande des fréquences moyennes, par le Règlement des Radiocommunications, et doit être modulé à un taux d'au moins 70 pour cent. Le récepteur doit être capable de recevoir les classes d'émission assignées aux besoins de la détresse dans la bande des fréquences moyennes par le Règlement des Radiocommunications. Dans les installations nouvelles, les appareils doivent aussi pouvoir émettie sur la haute fréquence et dans la classe d'émission prescrite par le Règlement des Radiocommunications pour les embarcations rescapées. Une Administration peut différer l'application de la prescription relative à la haute fréquence pendant une période ne dépassant pas une année à dater de la mise en vigueur de la présente Convention. 
(b) The apparatus shall be so designed that it can be used in an emergency by an unskilled person. The transmitter shall be fitted with an automatic keying device for the transmission of the alarm signal and the distress signal, as well as a key for manual transmissions. An Administration may delay the application of the requirement for an automatic keying device for a period not exceeding one year from the date of coming into force of the present Convention.

(c) A fixed-type aerial shall be provided together with means for supporting it at the maximum practicable height. In addition an aerial supported by a kite or balloon shall be provided if practicable.

(d) On the distress frequency the transmitter shall have a minimum normal range (as defined in paragraph $(/ /)$ of Regulation 10 ) of 25 miles using the fixed aerial.*

(e) In new installations the note frequency shall be between 450 and 1,350 cycles per second.

(f) The radio apparatus shall be operated from an accumulator battery with sufficient capacity to supply the transmitter for four hours continuous? under normal working conditions. If the battery is of a type that requires charging, means shall be available for charging the battery from the ship's power supply. In addition there shall be means for charging the battery after the lifeboat has been launched.

(g) When the power for the radio apparatus and the searchlight are drawn from the same battery, the battery shall have sufficient capacity to provide for the additional load of the searchlight.

(h) At sea a qualitied operator shall at weekly intervals bring the battery up to full charge if the battery is of a type which requires charging. and in any case shall test the transmitter using a suitable artificial aerial.

\section{Regulation 14}

\section{Lifeboas Porsable Radio A pparasus}

(a) The apparatus required by Regulation 13 of Chapter III shall be capable of ransmitting and receiving on the radiotelegraph frequency assigned by the Radio Regulations for the purpose of distress in the medium frequency band. The transmitter shall be capable of using a class of emission assigned by the Radio Regulations for the purpose of distress in the medium frequency band and shall be modulated to a depth of at least 70 per cent. The receiver shall be capable of receiving the classes of emissinn assigned by the Radio Regulations for the purpose of distress in the medium frequency band. In new equipment the apparatus shall also be capable of transmitting on the high frequency and the class of emission prescribed for survival craft by the Radio Regulations. An Administration may delay the application of the requirement for high frequency in the case of new equipment for a period not exceeding one year from the date of coming into force of the present Convention.

(b) The apparatus shall be so designed that it may be used in an emergency by an unskilled person. The transmitter shall be fitted with an automatic keying device for the transmission of the alarm signal and the distress signal, as well as a key for manual transmissions. An Administration

- In the absence of a measurement of the field strength, it may be assumed that this range will be obtained if the product of the height of the aerial above the water line and the aerial current is 10 metre-amperes. 
(b) Les appareils doivent être conçus de façon à pouvoir être utilisés, en cas d'urgence. par une personne inexpérimentée. L'émetteur doit être muni d'un dispositif de manipulation automatique pour l'émission du signal d'alarme et du signal de détresse, ainsi que d'un manipulateur pour l'émission manuelle. Une Aớministration peut différer l'application de la prescription relative à un manipulateur automatique pendant une période ne dípassant pas une année à dater de la mise en vigueur de la présente Convention.

(c) Un aérien du type fixe ainsi que les supports nécessaires pour le maintien à la bauteur maximum possible doivent se trouver à bord. En outre, un aérien supporté par un cerf-volant ou un ballon doit se trouver si possible à bord.

(d) Sur la fréquence de détresse l'émetteur doit avoir une portée minimum normale (telle que spécifiée au paragraphe $(/ 2)$ de la Règle 10) de 25 milles en utilisant l'aérien fixe.*

(e) Dans les installations nouvelles, la fréquence de modulation doit être comprise entre 450 et 1,350 cycles par seconde.

(f) L'appareil de radio doit être actionné par une batterie d'accumulateurs d'une capacité suffisante pour alimenter l'émetteur pendant 4 heures consécutives, dans des conditions normales d'exploitation. Si la batterie est d'un modèle à rechargement, on doit disposer de moyens permettant de charger la batterie sur le réseau électrique du navire. En outre, on doit disposer des moyens nécessaires pour charger la batterie après la mise à la mer de l'embarcation.

(g) Lorsque l'énergie nécessaire à l'appareil de radiotélégraphie et au projecteur est fournie par la même batterie. cette batterie doit avoir une capacité suffisante pour pourvoir à la charge supplémentaire occasionnée par le projecteur.

(h) Lorsque le navire est à la mer, un opérateur qualitié doit, chaque semaine, amener à pleine charge la batterie, si elle est d'un modèle à rechargement, et dans tous les cas essayer l'émetteur en utilisant une antenne fictive appropriée.

\section{Règle 14}

Appareils radioélectriques portatifs pour Embarcation de Sauverage

(a) Les appareils exigés par la Règle 13 du Chapitre III doivent pouvoir émettre et recevoir sur la fréquence radiotélégraphique assignée dans la bande des fréquences moyennes, par le Règlement des Radiocommunications, aux besoins de la détresse. L'émetteur doit être capable d'utiliser une classe d'émissions assignée aux besoins de la détresse dans la bande des fréquences moyennes par le Règlement des Radiocommunications et doit être modulé à un taux d'au moins 70 pour cent. Le récepteur doit être capable de recevoir les classes d'émissions assignées aux besoins de la détresse dans la bande des fréquences moyenne par le Règlement des Radiocommunications. Dans les équipements nouveaux, l'appareil doit aussi pouvoir émettre sur la haute fréquence et dans la classe d'émission prescrite par le Règlement des Radiocommunications pour les embarcations rescapées. Une Administration peut différer l'application de la prescription relative à la haute fréquence pour les équipements nouveaux pendant une période ne dépassant pas une année à dater de la mise en vigueur de la présente Convention.

(b) Les appareils doivent être conçus de façon à pouvoir être utilisés. en cas d'urgence. par une personne inexpérimentée. L'émetteur doit être muni d'un dispositif de manipulation automatique pour l'émission du signal d'alarme et du signal de détresse, ainsi que d'un manipulateur pour l'émission manuelle.

- A défaut de la mesure de l'intensité du champ, on peut admettre que cette portée sera atteinte si le produit de la hauteur de l'aérien au-dessus du niveau de la mer par l'intensité dans l'aérien est de 10 mètres-ampères. 
may delay the application of the requirement for an automatic keying device in the case of new equipment for a period not exceeding one year from the date of coming into force of the present Convention, and in the case of existing equipment for a period not exceeding three years from the date of coming into force of the present Convention.

(c) In new equipment. the note frequency shall be between 450 and 1,350 cycles per second.

(d) The apparatus shall be readily portable, watertight and capable of foating in sea water and also capable of being dropped into the sea witbout damage.

(e) The transmitter shall have at least 10 watts input to the anode of the final stage. and shall preferably derive its power from a hand generator. If operated from batteries these shall comply with conditions laid down by the Administration to ensure that the hatteries are of a durable type and are of sufficient capacity.

(f) An aerial shall be included. either self-supporting or capable of being supported by the mast of the lifeboat at the maximum practicable height.

(g) At sea a qualified operator shall at weekly intervals bring the battery up to full charge if the hattery is of a type which requires charging and in any case shall test the transmitter, using a suitable artificial aerial.

(h) For the purpose of this Regulation. new equipment means equipment supplied to a ship after the present Convention comes into force.

\section{Regulation 15}

\section{Radiotelephone Installasions}

(a) The ship's radiotelephone station shall be in the upper part of the ship, and, unless situated on the bridge, there shall be efficient communication with the bridge.

(b) The installation shall be capable of transwitting and receiving radiotelephony on the radiotelephone distress frequency and on at least one other frequency available for maritime radiotelephone stations in the medium frequency band under the Radio Regulations. In normal operation the depth of modulation shall be at least 70 per cent. at peak intensity.

(c) The transmitter shall have a minimum normal range of 150 miles, i.e., it shall be capable of transmitting clearly perceptible signals from ship to ship by day and under normal conditions and circumstances over this range. (Clearly perceptible signals will normally be received if the R.M.S. value of the field strength produced at the receiver by the unmodulated carrier is at least 25 microvolts per metre).*

(d) The receiver shall have sufficient sensitivity to receive an incoming signal as low as 50 microvolts by means of a loudspeaker.

(e) While the ship is at sea, there shall be available at all times a source of energy sufficient to operate the installation over the normal range required by paragraph $(c)$ of this Regulation. If batteries are provided they shall have sufficient capacity to operate the transmitter and receiver for at least six hours continuously under normal working conditions. In new installations an

- In the absence of field strength measurements it may be assumed that this range will be obtained by a power in the aerial of 15 watts (unmodulated carrier) with an aerial efficiency of 27 per cent. 
Une Administration peut différer l'application de la prescription relative au dispositif de manipulation automatique pour les equipements nouveaux pendant une période ne dépassant pas une année à dater de la mise en vigueur de la présente Convention, et. pour les équipements existants, pendant une période ne dépassant pas 3 ans à dater de la mise en vigueur de la présente Convention.

(c) Dans les équipements nouveaux. la fréquence de modulation doit être comprise entre 450 et 1,350 cycles par seconde.

(d) Les appareils doivent être facilement transportables, étanches et capables de flotter sur l'eau de mer. lis doivent pouvoir également être jetés à la mer sans être endommagés.

(e) L'émetteur doit fournir au moins 10 watts à l'anode de l'étage final. et doit de préférence être alimenté par un générateur actionné à la main. S il est alimenté par des batteries, ces dernières doivent être conformes aux spécifications établies par l'Administration pour s'assurer que les batteries sont d'un modèle durable et d'une capacité suffisante.

(f) L'équipement devra comporter un aérien, soit auto-supporté, soit pouvant être supporté par le mât de l'embarcation de sauvetage à la hauteur maximum possible.

(g) Lorsque le navire est à la mer. un opérateur qualifić doit, chaque semaine, amener à pleine charge la batterie, si elle est d'un modèle à rechargement, et dans tous les cas essayer l'émetteur en utilisant une antenne fictive appropriée.

(h) Dans le cadre de la présente Règle, l'expression "équipement nouveau" désigne un équipement fourni à un navire après la mise en vigueur de la présente Convention.

\section{Règle 15}

\section{Installations Radiotéléphoniques}

(a) La station de radiotéléphonie du navire doit être située à la partie supérieure du navire et, sauf si elle est placée sur la passerelle. il doit exister un moyen efficace de communication avec ladite passerelle.

(b) L'installation doit pouvoir émettre et recevoir en radiotéléphonie sur la fréquence radiotéléphonique de détresse et au moins sur une autre fréquence disponible pour les stations radiotéléphoniques maritimes dans la bande des moyennes fréquences, d’après le Règlement des Radiocomnunications. En exploitation normale, le taux de modulation doit être au moins de 70 pour cent à l'intensité de pointe.

(c) L'émetteur doit avoir une portée normale minimum de 150 milles, c'est-à-dire pouvoir émettre à cette distance des signaux clairement perceptibles de navire à navire. de jour et dans des conditions et des circonstances normales. (Des signaux clairement perceptibles seront normalement reçus si la valeur efficace de l'intensité de champ produite au récepteur par l'onde porteuse non modulée est au moins de 25 microvolts par mètre.)*

(d) Le récepteur doit avoir une sensibilité suffisante pour recevoir en haut-parleur un signal d'entrée d'une intensité aussi basse que 50 microvolts.

(e) Pendant que le navire est à la mer, une source d’énergie suffisante pour faire fonctionner l'installation sur les portées normales prescrites par le paragraphe $(c)$ de la présente Règle doit être disponible à tout instant. Les batteries, s'il en existe, doivent avoir une capacité suffisante pour faire fonctionner l'émetteur et le récepteur pendant au moins six heures consécu-

- A défaut de mesures d'intensité de champ, on peut admettre que celte portée sera obtenue avec une puissance de 15 ivalts dans l'aérien (onde porteuse non modulée) avec un rendement da l'aérien de 27 pour cent. 
emergency source of energy shall be provided in the upper part of the ship unless the main source of energy is so situated.

(f) While at sea the batteries (if provided) shall be kept charged so as to meet the requirement of paragraph $(e)$ of this Regulation.

\section{PART D.-RADIO LOG}

\section{Regulation 16}

\section{Radio Log}

The radio log (diary of the radio service) required by the Radio Regulations shall be kept in the radio operating room during the voyage. It shall be available for inspection by the officers authorised by the Administration to make such inspections. Every radio operator shall enter in the radio log his name, the times at which he goes on and off watch, and all incidents occurring during his watch connected with the radio service which may appear to be of importance to safety of life at sea. In addition to the entries required by the Radio Regulations there shall be entered in the radio $\log :-$

\section{Radiotelegraph Log}

(i) details of the maintenance, including a record of the charging, of the batteries in such form as may be prescribed by the Administration;

(ii) a daily statement that the requirement of paragraph ( $p)$ of Regulation 10 has been fulfilled:

(iii) details of tests of the emergency transmitter and emergency power supply made under paragraph ( $(t)$ of Regulation 10;

(iv) in ships fitted with an auto alarm details of tests made under para. graph (c) of Regulation 11;

(v) details of the maintenance, including a record of the charging, of the batteries (if applicable), and tests of the transmitters fitted in motor lifeboats, under paragraph $(h)$ of Regulation 13;

(vi) details of the maintenance, including a record of the charging, of the batteries (if applicable), and tests of lifeboat portable transmitters under paragraph ( $g$ ) of Regulation 14;

\section{Radiotelephone Log}

(vii) in ships ftted with a radiotelephone installation details of the maintenance, including a record of the charging, of the batteries (if provided), under paragraph ( $f$ ) of Regulation 15:

(viii) details of the maintenance, including a record of the charging, of the batteries (if applicable), and tests of lifeboat portable transmitters under paragraph $(g)$ of Regulation 14. 
tives dans des conditions normales d'exploitation. Dans les installations nouvelles, on doit prévoir une source d'énergie de secours dans la partie supérieure du navire, à moins que la source principale d'énergie n'y soit déjà située.

(f) Pendant que le navire est à la mer, les batteries, s'il en existe, doivent être maintenues suffisamment chargées pour répondre aux exigences du paragraphe $(e)$ de la présente Règle.

\section{PARTIE D.-JOURNAL DE BORD RADIO \\ Règle 16}

\section{Journal de Bord Radio}

Le journal de bord radio (journal du service radiocommunications) exigé par le Règlement des Radiocommunications devra être conservé dans la cabine de radiotélégraphie pendant le voyage. It devra être tenu pour inspections à la disposition du personnel autorisé par l'Administration à procéder à de telles inspections. Chaque opérateur devra porter au journal de bord radio son nom, les heures où il commence et termine l'ćcoute ainsi que tous les événements survenant pendant son service intéressant la radio et qui semblent avoir de l'importance pour la sécurité de la vie humaine en mer. Outre les inscriptions exigées par le Règlement des Radiocommunications. les indications suivantes devront figurer au journal de bord radio:

\section{Journal de bord radiotélégraphique}

(i) une mention détaillée de l'entretien des batteries, y compris leur chargement, dans la forme prescrite par l'Administration:

(ii) un rapport journalier mentionnant que les prescriptions du paragraphe $(\rho)$ de la Règle 10 ont été observées;

(iii) le détail des essais de l'émetteur de secours et de la source d'énergie de secours effectués conformément au paragraphe $(t)$ de la Règle 10:

(iv) sur les navires équipés d'auto-alarme les détails de tous les essais faits conformément au paragraphe (c) de la Rìgle 11;

(v) une mention détaillée de l'entretien des batteries, y compris leur chargement, s'il y a lieu, et des essais des émetteurs installés dans les embarcations de sauvetage à moteur, conformément au para. graphe $(h)$ de la Règle 13:

(vi) une mention détaillée de l'entretien des batteries, y compris leur chargement, s'il y a lieu, ainsi que des essais de l'émetteur portatif des embarcations de sauvetage selon le paragraphe $(g)$ de la Règle 14.

\section{Journal de Bord Radiotéléphonique}

(vii) sur les navires équipés d'une installation radiotéléphonique une mention détaillée de l'entretien des batteries, s'il en existe, y compris leur chargement, conformément au paragraphe $(f)$ de la Règle 15:

(viii) une mention détaillée de l'entretien des batteries, y compris leur chargement, s'il y a lieu, ainsi que des essais de l'émetteur portatif des embarcations de sauvetage selon le paragraphe $(g)$ de la Règle 14. 


\section{CHAPTER V.-SAFETY OF NAVIGATION \\ Regulation 1 \\ Application}

Notwithstanding the provisions of Regulation 3 of Chapter 1, this Chapter. unless otherwise expressly provided in this Chapter, refers to all ships on all voyages, except ships of war.

\section{Regulation 2}

\section{Danger Messages}

(a) The master of every ship which meets with dangerous ice, a dangerous derelict, or any other direct danger to navigation, or a tropical storm, is bound to communicate the information by all the means at his disposal to ships in the vicinity, and also to the competent authorities at the first point on the coast with which he can communicate. The form in which the information is sent is not obligatory. It may be transmitted either in plain language (preferably English) or by means of the International Code of Signals (Radio Section). It should be broadcast to all ships in the vicinity and sent to the first point on the coast to which communication can be made, with a request that it be transmitted to the appropriate authorities.

(b) Each Administration will take all steps which it thinks necessary to ensure that when intelligence of any of the dangers specified in paragraph (a) is received, it will be promptly brought to the knowledge of those concerned and communicated to other Administrations interested.

(c) The transmission of messages respecting the dangers specified is free of cost to the ships concerned.

(d) All messages issued under this Regulation shall be preceded by the Safety Signal, using the procedure as prescribed by the Radio Regulations.

\section{Regulation 3 \\ Information required in Danger Messages}

The following information is desired in danger messages, the time in all cases being Greenwich Mean Time :

(a) Ice, Derelicts and other Direct Dangers to Navigation.

(i) the kind of ice, derelict or danger observed:

(ii) the position of the ice, derelict or danger when last observed:

(iii) the time and date when the observation was made.

(b) Tropical Storms - Hurricanes in the West Indies. Typhoons in the China Sea, Cyclones in Indian waters, and storms of a similar nature in other regions).

(i) A statement that a tropical storm has been encountered. This obligation should be interpreted in a broad spirit, and information transmitted whenever the master has good reason to believe that a tropical storm exists in his neighbourhood.

(ii) Meteorological Information. Each shipmaster should add to his warning message as much of the following meteorological information as he finds practicable:-

- the Greenwich Mean Time, date and position of the ship when the observations were taken: 


\section{CHAPITRE V.-SECURITE DE LA NAVIGATION}

\section{Règle 1}

\section{Application}

Nonobstant les dispositions de la Règle 3 du Chapitre l, le présent Chapitre s'applique, sauf dispositions expresses contraires qui y figureraient. à tous les navires, excepté les navires de guerre, pour tous les voyages.

\section{Règle 2}

\section{Messages de Dangers}

(a) Le capitaine de tout navire se trouvant en présence de glaces ou d'une épave dangereuses oll de tout autre danger immédiat pour la navigation, ou d'une tempête tropicale, est tenu d'en informer par tous les moyens dont il dispose les navires dans le voisinage, ainsi que les autorités compétentes au premier point de la còte avec lequel il peut communiquer. Aucune forme spéciale de transmission n'est imposée. L'information peut être transmise soit en langage clair (de préférence en anglais), soit au moyen du Code international de Signaux (Section Radio). Elle devrait être transmise à tous les navires dans le voisinage et envoyée au premier point de la côte où la communication peut se faire avec prière de transmettre à l'autorité compétente.

(b) Chaque Administration prendra telles mesures quelle jugera nécessaires pour que toute information reçue conceraant un danger prévu au paragraphe précédent soit promptement portée à la connaissance des intéressés et communiquée aux autres Administrations aurquelles elle peut être utile.

(c) La transmission des messages cuncernant ces dangers est gratuite pour les navires intéressés.

(d) Tous les messages transmis en vertu de la présente Règle seront précédés du signal de sécurité en utilisant la procédure prescrite par le Règlement des Radiocommunications.

\section{Règle 3}

\section{Information requise dans les Messages de Dangers}

Il est désirable de fournir dans les messages de dangers les renseignements suivants, l'beure étant, dans tous les cas, l'heure moyenne de Greenivich:

(a) Glaces, épaves et autres dangers immédiats pour la navigation:

(i) la nature de la glace, de l'épave ou du danger observés;

(ii) la position de la glace, de l'épave ou du danger lors de la dernière observation:

(iii) la date et l'heure où l'observation a été faite.

(b) Tempêtes tropicales (Ouragans aux Antilles, typhons dans les mers de Chine, cyclones dans l'Océan Indien et tempêtes de même nature dans les autres régions):

(i) Message signalant qu'une tempête tropicale a été rencontrée. Cette obligation doit être comprise dans un esprit large et l'information devrait être transmise toutes les fois que le capitaine a lieu de croire qu'une tempête tropicale sévit dans son voisinage.

(ii) Renscignements météorologiques. Tout capitaine de navire devrait ajouter à son message d'avertissement le plus de renseignements météorologiques qu'il lui sera possible parmi les suivants:

-l'heure moyenne de Greenwich, la date et la position du navire au moment où l'observation a été faite: 
-barometric pressure (stating millibars, inches, or millimetrcs, and whether corrected or uncorrected);

-barometric tendency (the change in barometric pressure during the past three hours):

- true wind direction :

- wind force (Beaufort scale) :

- state of the sea (smooth, moderate, rough, high);

- swell (slight, moderate, heavy) and the true direction from which it comes. Period or length of swell (short, average, long) would also be of value :

-true course and speed of ship.

(c) Subsequent Observations. When a master has reported a tropical or other dangerous storm, it is desirable, but not obligatory, that other observations be made and transmitted hourly, if practicable, but in any case at intervals of not more than three hours, so long as the ship remains under the influence of the storm.

Ice

\section{Examples}

TTT Ice. Large berg sighted in 4605 N., 4410 W., at 0800 GMT, May 15.

\section{Derelicto}

TTT Derelict. Observed derelict almost submerged in 4006 N., 1243 W., at 1630 GMT. April 21.

\section{Danger to Navigation}

TTT Navigation. Alpha lightship not on station. 1800 GMT. January 3.

\section{Tropical Storm}

TTT Storm. 0030 GMT. August 18. 2204 N., 11354 E. Barometer corrected 994 millibars, tendency down 6 millibars. Wind NW., force 9. heavy squalls. Heavy easterly swell. Course 067, 5 knots.

TIT Storm. Appearances indicate approach of hurricane. 1300 GMT. September 14. 2200 N., 7236 W. Barometer corrected 29.64 inches, tendency down 015 inches. Wind NE., force 8, frequent rain squalls. Course 035. 9 knots.

TIT Storm. Conditions indicate intense cyclone has formed. 0200 GMT. May 4. 1620 N.. 9203 E. Barometer uncorrected 753 millimetres, tendency down 5 millimetres. Wind S. by W., force 5 . Course 300,8 knots.

TTT Storm. Typhoon to southeast. 0300 GMT. June 12. 1812 N., 12605 E. Barometer falling rapidly. Wind increasing from $\mathbf{N}$.

\section{Regulation 4}

\section{Meteorological Services}

(a) The Contracting Governments undertake to encourage the collection of meteorological data by ships at sea and to arrange for their examination. dissemination and exchange in the manner most suitable for the purpose of aiding navigation. Administrations shall encourage the use of instruments of a high degree of accuracy, and shall facilitate the checking of such instruments upon request. 
- la pression barométrique (en indiquant si elle est évaluée en millibars, en pouces anglais ou en millimètres et si la lecture a été corrigée ou non):

- la tendance barométrique (le changement survenu dans la pression barométrique pendant les trois dernières heures);

-la direction vraie du vent;

-la force du vent (échelle Beaufort);

-l'état de la mer (calme, modérée, forte, démontée);

- la houle (modérée, moyenne. forte) et la direction vraie d'où elle vient. Une indication de la période ou de la longueur de la houle (courte, moyenne, longue) serait également précieuse: -la route vraie et la vitesse du navire.

(c) Observations ultérieures. Lorsqu'un capitaine a signalé une tempête tropicale ou toute autre tempête dangereuse, il est souhaitable mais non obligatoire de relever d'autres observations et de les transmettre toutes les heures si possible, mais en tout cas à des intervalles de trois heures au maximum, aussi longtemps que le navire reste sous l'intluence de la tempête.

\section{Glace}

\section{Exemples}

TTT Glace. Grand iceberg aperçu à 4605 N., 4410 W., ว̀ 0800 GMT. 15 mai.

\section{Épare}

TTT Épave. Épave observée presque submergée à 4006 N., 1243 W., à 1630 GMT. 21 avril.

\section{Danger pour la Navigation}

TTT Navigation. Bateau phare Alpha pas à son poste. 1800 GMT. 3 janvier.

\section{Tempête Tropicale}

TTT Tempête. 0030 GMT. 18 août. 2204 N., 11354 E. Baromètre corrigé 994 millibars, tendance à la baisse 6 millibars. Vent NW., force 9, forts grains. Forte houle de l'Est. Route 067, 5 nceuds.

TTT Tempête. Les apparences indiquent l'approche d'un ouragan. 1300 GMT. 14 septembre. 2200 N., 7236 W. Baromètre corrigé 29,64 pouces, tendance à la baisse 0.015 pouces. Vent NE., force 8. grains de pluie fréquents. Route 035. 9 noeuds.

TTT Tempête. Les conditions indiquent la formation d'un cyclone intense. 0200 GMT. 4 mai. 1620 N., 9203 E. Baromètre non corrigć 753.3 millimètres, tendance à la baisse 5 millimètres. Vent $S$. quart $S W$., force 5 . Route 300,8 nœuds.

TTT Tempête. Typhon dans le SE. 0300 GMT. 12 juin. 1812 N., $12605 \mathrm{E}$. Le baromètre baisse rapidement. Le vent augmente du Nord.

\section{Règle 4}

\section{Services méréurologiques}

(a) Les Gouvernements contractants s'engagent à encourager les navires à la mer à recueillir les renseignements d'ordre mćtéorologique, à les fajre examiner, propager et à se les communiquer de la manière la plus efficace dans le but de venir en aide a la navigation. Les Administrations doivent encourager l'emploi d'instruments présentant un haut degré d'exactitude et faciliter l'inspection de ces instruments, lorsqu'elle sera requise. 
(b) In particular, the Contracting Governments undertake to co-operate in carrying out, as far as practicable, tbe following meteorological arrangements:-

(i) To wam ships of gales, storms and tropical storins, both by the issue of radio messages and by the display of appropriate signals at coastal points.

(ii) To issue daily, by radio, weather bulletins suitable for shipping, containing data of existing weather and ice conditions, forecasts, and when practicable, sufficient additional information to enable simple weather charts to be prepared at sea.

(iii) To prepare and issue such publications as may be necessary for tbe efficient conduct of meteorological work at sea.

(iv) To arrange for selected ships to be equipped with tested instruments (such as a barometer, a barograph, a psycbrometer, and suitable apparatus for measuring sea temperature) for use in this service, and to take meteorological observations at standard synoptic hours (at least four times daily, whenever circumstances permit) and to encourage other ships to take observations in a modified form, particularly when in areas where shipping is sparse; these ships to transmit their observations by radio for the benefit of the various official meteorological services, repeating the information for the benelit of ships in the vicinity. When in the vicinity of a tropical storm, or of a suspected tropical storm, ships should be encouraged to take and transmit their observations at more frequent intervals whenever practicable, bearing in mind navigational preoccupations of ships' officers during storm conditions.

(v) To arrange for the reception and transmission by coast radio stations of weather messages from and to ships. Ships which are unable to communicate direct with shore shall be encouraged to relay their weather messages through ocean weather ships or through other ships which are in contact with shore.

(vi) To encourage all masters to inform ships in tbe vicinity and also shore stations whenever they experience a wind speed of 50 knots or more (force 10 on the Beaufort scale).

(vii) To endeavour to obtain a uniform procedure in regard to the international meteorological services already specified, and, as far as is practicable, to conform to the recommendations made by the International Meteorological Organisation, to which the Contracting Governments may refer for study and advice any meteorological question which may arise in carrying out the present Convention.

(c) The information provided for in this Regulation shall be fumished in form for transmission and transmitted in the order of priority prescribed by the Radio Regulations, and during transmission "to all stations" of meteorological information, forecasts and warnings, all ship stations must conform to the provisions of the Radio Regulations. 
(b) En particulier, les Gouvernements contractants s'engagent à collaborer a l'application, dans la plus grande mesure possible, des dispositions météorologiques suivantes :

(i) Avertir les navires des coups de vents, tempêtes ct tempêtes tropicales. tant par la transmission de messages radioélectriques que p3r l'usage de signaux appropriés sur des points de la côte;

(ii) Transmettre journellement par radio des bulletins sur l'útat du temps à l'usage de la navigation, et donnant des renseignements sur les conditions actuelles du temps et des glaces, ainsi que des privisions, et. si possible. des informations complementaires suffisantes pour permettre l'établissement en mer de cartes météorologiques simples;

(iii) Rédiger et publier toutes publications pouvant être nécessaires à l'exécution efticace du travail météorologique en mer;

(iv) Prendre des mesures pour que certains navires spécialement désignés soient pourvus d'instruments contrôlés (tels que baromètre, barographe, psychromètre. et appareil permettant de mesurer la température de la mer) destinés à être employés à cette fin et prennent des observations météorologiques, à des heures synoptiques convenues (au moins quatre fois par jour lorsque les conditions le permettent); et encourager d'autres navires à prendre des observations sous une forme modifiée, en particulier lorsqu'ils se trouvent dans des régions où la ravigation est peu intense, étant entendu que ces navires transmettront ces observations par radio dans lintérêt des divers services météorologiques officiels et répéteront leurs informations dans l'intérêt des navires se trouvant dans le voisinage. Dans le voisinage d'une tempête tropicale ou d'une tempête tropicale présumée. les navires seront encouragés à prendre et à transmettre chaque fois qu'il est possible leurs observations à des intervalles plus fréuuents. compte tenu cependant du fait que les otficiers du navire peuvent ćtre préoccupés par les tàches de la navigation dans des conditions de tempète.

(v) Assurer la réception et la transmission par les stations cótières de radio des messages météorologiques en provenance et à destination des navires. Les navires qui sont dans l'impossibilité de communiquer directement avec la côte seront encouragés à transmettre leurs messages météorologiques par l'intermédiaire des navires du service météorologique en haute mer ou d’autres navires qui sont en liaison avec la côte;

(vi) Encourager tous les capitaines de navires à prévenir les navires dans le voisinage, ainsi que les stations côtières, lorsqu'ils rencontrent une vitesse de vent égale ou supérieure à 50 nœuds (force 10 de l'échelle Beaufort);

(vii) S'efforcer d'obtenir une procédure uniforme en ce qui concerne les services métiorologiques internationaux déjà spicilicis, et se conformer dans la mesure du possible aux recommandations de l'Organisation météoro'ogique internationale. à qui les Gouvernements contractants pourront se référer pour étude et avis sur toute question d'ordre météorologique pouvant se présenter dans l'application de la présente Convention.

(c) Les informations visées dans la présente Règle doivent être données dans la forme prévue pour leur émission et seront transmises dans l'ordre de priorité prescrit par le Règlement des Radiocommunications; pendant la durée des transmissions "à toutes les stations" de renseignements météorologiques, avertissements et prévisions. toutes les stations de bord doivent se conformer aux dispositions du Règlement des Radiocommunications. 
(d) Forecasts, warnings, synoptic and otber meteorological reports intended for ships shall be issued and disseminated by the national service in the best position to serve various zones and areas, in accordance with mutual arrangements made by the Contracting Governments concerned.

\section{Regulation 5 \\ Ice Patrol Service}

(a) The Contracting Governments undertake to continue an ice patrol and a service for study and observation of ice conditions in the North Atlantic. During the whole of the ice season the south-eastern, southern and south-western limits of the regions of icebergs in the vicinity of the Grand Banks of Newfoundland shall be guarded for the purpose of informing passing ships of the extent of this dangerous region; for the study of ice conditions in general: and for the purpose of affording assistance to ships and crews requiring aid within the limits of operation of the patrol ships. During the rest of the year the study and observation of ice conditions shall be maintained as advisable.

(b) Ships and aircraft used for the ice patrol service and the study and observation of ice conditions may be assigned other duties by the managing Government, provided that such other duties do not interfere with their primary purpose or increase the cost of this service.

\section{Regulatios 6 \\ Ice Putrol. Management and Cost}

(a) The Government of the United States of America agrees to continue the management of the ice patrol service and the study and observation of ice conditions, including the dissemination of information received therefrom. The Contracting Governments specially interested in these services undertake to contribute to the expense of maintaining and operating these services; each contribution to be based, as far as practicable. upon the total gross tonnage of the vessels of each contributing Govemment passing through the regions of icebergs guarded by the Ice Patrol. The Maritime Safety Committee is invited to undertake studies of these tonnages for the purpose of advising the contributing Governments. The Contracting Governments specially interested undertake to contribute to the expense of maintaining and operating these services in the proportions of their respective contributions as agreed to under the terms of the International Convention for the Safety of Life at Sea, 1929. until such contributions are modified as provided for in this Regulation.

(b) Each of the contributing Governments has the right to alter or discontinue its contribution, and other Contracting Governments may undertake to contribute to the expense. The contributing Government which avails itself of this right will continue responsible for its current contribution up to the 1st September following the date of giving notice of intention to alter or discontinue its contribution. To take advantage of the said right it must give notice to the managing Government at least six months before the said Ist September.

(c) If, at any time, the United States Government should desire to discontinue these services, or if one of the contributing Governments should express a wish to relinquish responsibility for its pecuniary contribution. or to have its contribution altered, or another Contracting Government should 
(d) Les prévisions, avertissements, rapports synoptiques et autres rapports météorologiques à l'usage des navires doivent être transmis et propagés par le service national dans la position la plus favorable pour desservir les différentes zones et régions suivant des accords mutuels entre les pays contractants intéressćs.

\section{Règle 5}

\section{Service de Recherche des Glaces}

(a) Les Gouvernements contractants s'engagent à maintenir un service de recherche des glaces et un service d'étude et d'observation du régime des glaces dans l'Atlantique Nord. Pendant toute la saison des glaces, les limites sud-est, sud et sud-ouest des régions des icebergs dans le voisinage des grands bancs de Terre-Neuve seront surveillées dans le but de fournir aux navires qui passent des informations sur l'étendue de la région dangereuse; pour étudier le régime des glaces en général; et pour prêter assistance aux navires et équipages qui ont besoin d'aide dans la zone d'action des navires patrouilleurs. Pendant le reste de l'année. l'ćtude et l'observation des glaces doivent être poursuivies suivant les nécessités.

(b) Les navires et avions affectés au service de recherche des glaces et à l'étude et observation des glaces peuvent se voir assigner d'autres fonctions par le Gouvernement chargé de l'exécution de ce service. à condition que ces autres fonctions ne gênent pas leur objet principal et n'augmentent pas les frais de ce service.

\section{Règle 6 \\ Recherche des Glaces. Gestion et Frais.}

(a) Le Gouvernement des États-Unis d'Amérique accepte de continuer à assumer la gestion du service de recherche des glaces, et de poursuivre l'étude et l'observation des glaces, ainsi que la diffusion des informations ainsi obtenues. Les Gouvernements contractants qui sont spćcialement intéressés à ces services s'engagent à contribuer aux dépenses d'entretien et de fonctionnement de ces services ; la contribution de chacun des Gouvernements participants étant calculée, dans la mesure du possible, en fonction du tonnage brut total de leurs navires respectifs naviguant dans les régions des icebergs où patrouille le Service de Recherche des Glaces. Le Comité de la Sécurifé Maritime est invité à faire des recherches sur ces tonnages. afin de pouvoir donner aux Gouvernements participants des renseignements à ce sujet. Les Gouvernements contractants spécialement intéressés s'engagent à contribuer aux frais d'entretien et de fonctionnement de ce service dans la proportion de leurs quotes-parts respectives telles qu'elles ont été convenues aux termes de la Convention internationale de 1929 pour la Sauvegarde de la Vie Humaine en Mer, jusqu'à ce que ces quotes-parts soient modifiées conformément aux dispositions de la présente Règle.

(b) Chacun des Gouvernements participants a le droit de modifier ou de cesser sa participation, et d'autres Gouvernements contractants peuvent s'engager à participer aux frais. Le Gouvernement participant qui usera de cette faculté restera tenu de sa contribution en cours jusqu'au $1^{\text {or }}$ septembre qui suivra la date de notification de son intention de modifier ou de cesser sa contribution. Pour user de ladite faculté, il devra notifier son intention au Gouvernement responsable six mois au moins avant ledit $1^{\text {er }}$ septembre.

(c) Au cas où. à un moment quelconque, le Gouvernement des États-Unis désirerait cesser de gérer ces services, oll que l'un des Gouvernements participants exprimerait le désir de ne plus assumer la charge de sa contribution pécuniaire ou de la voir modifier, ou si un autre Gouvernement contractant 
desire to undertake to contribute to the expense, the contributing Governments shall settle the question in accordance with their mutual interests.

(d) The contributing Governments shall have the right by common consent to make from time to time such alterations in the provisions of this Regulation and of Regulation 5 as appear desirable.

(e) Where this Regulation provides that a measure may be taken after agreement among the contributing Governments, proposals made by any Contracting Government for effecting such a measure shall be communicated to the managing Government which shall approach the other contributing Governments with a view to ascertaining whether they accept such proposals, and the results of the enquiries thus made shall be sent to the other contributing Governments and the Contracting Government making the proposals. In particular, the scale of contributions to the cost of the services to be made by the Contracting Governments specially interested shall be reviewed by those Governments in consultation at intervals not exceeding three years. The managing Government shall initiate the action necessary to this end.

\section{Regulation 7}

\section{Speed Near lce}

When ice is reported on or near his course the master of every ship at night is bound to proceed at a moderate speed or to alter his course so as to go well clear of the danger zone.

\section{Regulation 8}

\section{North Ailantic Routes}

(a) The practice of following recognised routes across the North Atlantic in both directions has contributed to safety of life at sea and should be recommended to all ships.

(b) The selection of the routes and the initiation of action with regard to them is left to the responsibility of the shipping companies concerned. The Contracting Governments will assist the companies, when requested to do so, by placing at their disposal any information bearing on the routes which may be in the possession of the Governments.

(c) The Contracting Governments undertake to impose on the companies the obligation to give public notice of the regular routes which they propose their ships should follow, and of any changes made in these routes; they will also use their influence to induce the owners of all ships crossing the Atlantic to follow, so far as circumstances will permit, the recognised routes, and to induce the owners of all ships crossing the Atlantic bound to or from ports of the United States or Canada via the vicinity of the Grand Banks of Newfound. land to avoid. as far as practicable, the fishing banks of Newfoundland north of latitude $43^{\circ} \mathrm{N}$. during the tishing season, and to pass outside regions known or believed to be endangered by ice.

(d) The Government managing the ice patrol service is requested to report to the Administration concerned any ship which is observed not to be on any regular, recognised or advertised route, or which crosses the abovementioned fishing banks during the fishing season, or which, when proceeding to or from parts of the United States or Canada, passes through regions known or believed to be endangered by ice. 
désirait s'engager à participer aux frais, les Gouvemements participants régleront la question au mieux de leurs intérêts réciproques.

(d) Les Gouvernements participants ont le droit d'apporter aux dispositions de la présente Règle et de la Règle 5 d'un commun accord et en tout temps les changements qui seraient jugés désirables.

(e) Dans les cas où la présente Règle prévoit la possibilité de prendre une mesure après accord entre les Gouvernements participants, toutes propositions présentées par un Gouvernement contractant quelconque à cet effet, doivent être transmises au Gouvernement chargé de l'exécution du service, qui se mettra en rapport avec les autres Gouvernements participants dans le but de s'assurer s'ils acceptent ces propositions. cl les résultats de l'enquête ainsi faite seront communiqués aux autres Gouvernements participants ainsi qu'au Gouvernement contractant auteur des propositions. En particulier, le barème des participations respectives des Gouvernements contractants spécialement intéressés aux frais du Service, sera révisé par ces Gouvernements au cours de consultations tenues a des intervalles ne dépassant pas trois ans. Le Gouvermement chargé de l'exécution du service doit prendre l'initiative des mesures nécessaires à ces fins.

\section{Règle 7}

Vitesse dans le voisinage des glaces

Lorsque des glaces sont signalées sur la route ou près de la route à suivre. le capitaine de tout navire est tenu de marcher pendant la nuit à une allure modérée ou de changer de route, de manière à s'écarter nettement de la zone dangereuse.

\section{Règle 8}

\section{Roures de l'Atlantique Nord}

(a) La pratique consistant à suivre des routes définies pour la traversée de l'Atlantique du Nord, dans l'un et l'autre sens, a contribué à la sauvegarde de la vie humaine en mer et devait être recommandée à tous les navires.

(b) Le choix des routes et l'initiative des mesures à prendre à cet égard sont laissés à la responsabilité des compagnies de navigation intéressées. Les Gouvernements contractants prêteront leurs concours à ces compagnies, lorsqu'ils en seront sollicités, en ruettant à leur disposition tous les renseigne. ments sur les routes qui peuvent être en possession des Gouvernements.

(c) Les Gouvernements contractants s'engagent à imposer aux compagnies l'obligation de publier les routes régulières qu'elles se proposent de faire suivre à leurs navires ainsi que tous changements qui peuvent leur être apportés. Ils useront égaleınent de leur influence pour inviter les armateurs de tous les navires traversant l'Atlantique à suivre, dans la mesure où les circonstances le pcrmettront, les routes reconnues, et d'inviter les armateurs de tous navires traversant l'Atlantiquc à destination ou en provenance des ports des États-Unis ou du Canada. en passant au voisinage des grands bancs de Terre-Neuve, à éviter, autant qu'il est possible, pendant la saison de pêche, les lieux de péche de Terre-Neuve, au nord du $43^{\text {bmo }}$ degré de latitude Nord et à faire route en dehors des régions où des glaces dangereuses existent ou sont supposées exister.

(d) Le Gouvernement chargé de l'exécution du Service de Recherche des Glaces est invité à signaler à l'Administration intéressée tout navire dont on constate la présence en dehors d'une route régulière reconnue ou annoncée, ou qui traverse les bancs de pêche susmentionnés pendant la saison de pêche, oll qui, faisant route à destination ou en provenance d'un port des Etats-Unis ou du Canada, traverse des régions ou des glaces dangereuses existent ou sont supposées exister. 


\section{Regulation 9 \\ Misuse of Distress Signals}

The use of an international distress signal. except for the purpose of indicating that a ship or aircraft is in distress, and the use of any signal which may be confused with an international distress signal, are probibited on every ship or aircraft.

\section{Regulation 10}

\section{Distress Messages-Procedure}

(a) The master of a ship at sea, on receiving a signal from any source that a ship or aircraft or survival craft thereof is in distress, is bound to proceed with all speed to the assistance of the persons in distress informing them if possible that he is doing so. If he is unable or, in the special circumstances of the case, considers it unreasonable or unnecessary to proceed to their assistance, he must enter in the logbook the reason for failing to proceed to the assistance of the persons in distress.

(b) The master of a ship in distress, after consultation, so far as may be possible, with the masters of the ships which answer his call for assistance, has the right to requisition such one or more of those ships as he considers best able to render assistance, and it shall be the duty of the master or masters of the ship or ships requisitioned to comply with the requisition by continuing to proceed with all speed to the assistance of persons in distress.

(c) The master of a ship shall be released from the obligation imposed by paragraph $(a)$ of this Regulation when he learns that one or more ships other than his own have been requisitioned and are complying with the requisition.

(d) The master of a ship shall be released from the obligation imposed by paragraph $(a)$ of this Regulation, and, if his ship has been requisitioned, from the obligation imposed by paragraph $(b)$ of this Regulation, if he is informed by the persons in distress or by the master of another ship which has reached such persons that assistance is no longer necessary.

(e) The provisions of this Regulation do not prejudice the International Convention for the unification of certain rules with regard to Assistance and Salvage at Sea, signed at Brussels on the 23rd September. 1910. $\left({ }^{5}\right)$ particularly the obligation to render assistance imposed by Article 11 of that Convention.

\section{Regulation 11}

\section{Signalling Lamps}

All ships of over 150 tons gross tonnage, when engaged on international voyages, shall have on board an efficient daylight signalling lamp.

\section{Regulation 12}

\section{Direction-Finding A pparalus}

(a) All ships of 1.600 tons gross tonnage and upwards, when engaged on international voyages, shall be fitted with direction-finding apparatus complying with the provisions of Regulation 12 of Chapter IV. but the provision of such apparatus on ships between 1,600 and 5,000 tons gross tonnage may be deferred for a period of 2 years from the date on which the present Convention comes into force if in the opinion of the Administration this is necessary.

$$
\text { (') "Treaty Series No. } 4 \text { (1913)," Cd. } 6677 .
$$




\section{Règle 9}

\section{Emploi injustifié des signaux de dérresse}

L'emploi d'un signal international de détresse, sauf s'il s'agit de signaler qu'un navire ou un avion est en détresse. ainsi que l'emploi d'un signal pouvant être confondu avec un signal international de détresse sont interdits sur tous les navires et avions.

\section{Règle 10}

\section{Messages de détresse. Procédure}

(a) Le Capitaine d'un navire en mer, qui reçoit, de quelque source que ce soit, un message indiquant qu'un navire ou un avion ou leurs embarcations rescapces se trouvent en détresse, est tenu de se porter à toute vitesse au secours des personnes en détresse en les informant, si possible, de ce fait. En cas d'impossibilité ou si, dans les circonstances spéciales où il se trouve, il n'estime ni raisonnable ni nécessaire de se porter à leur secours, il doit inscrire au livre de bord la raison pour laquelle il ne se porte pas au secours des personnes en détresse.

(b) Le Capitaine d'un navire en détresse, après avoir consulté, autant que cela peut étre possible, les capitaines des navires qui ont répondu à son appel de secours, a le druit de réqusititionner tel ou tels de ces navires qu'il considère les plus capables de porter sccours, et le Capitaine ou les Capitaines des navires réquisitionnés ont l'ubligation de se soumettre à la réquisition en continuant à se rendre à toute vitesse au secours des personnes en détresse.

(c) Le Capitaine d'un navire est libéré de l'obligation imposée par le paragraphe (a) de la présente Règle, lorsqu'il apprend qu'un ou plusieurs navires autres que le sien ont été réquisitionnés et se rendent à la réquisition.

(d) Le Capitaine d'un navire est libéré de l'obligation inposée par le paragraphe $(a)$ de la présente Règle et, si son navire a été réquisitionné, de l'obligation imposée par le paragraphe $(b)$ de la présente Règle, s'il est informé par les personnes en détresse ou par le Capitaine d'un autre navire qui est arrivé auprès de ces personnes, que le secours n'est plus nécessaire.

(e) Il n'est pas dérogé par les prescriptions de la présente Règle aux dispositions de la Convention Internationale pour l'unification de certaines règles en nuatière d'assistance et de sauvetage en mer, signée à Bruxelles le 23 septembre 1910 , particulièrement en cc qui concerne l'obligation de porter secours, imposée par l'Article 11 de ladite Convention.

\section{Règle 11}

\section{Fanal à signawx}

Tous les navires d'une jauge brute de plus de 150 tonneaux eflectuant des voyages internationaux, doivent avoir à bord un fanal à signaux de jour efficace.

\section{Règle 12}

\section{Radiogoniomètre}

(a) Tout navire de 1600 tonneaux de jauge brute et au-dessus, effectuant des voyages internationaux, doit être pourvu d'un radiogoniomètre répondant aux dispositions de la Règle 12. Cliapitre IV, mais l'installation de cel appareil sur des navires de 1.600 à 5.000 tonneaux de jauge brute pourra être différće pendant une période de 2 ans à partir de la date d'entrée en vigueur de la présente Convention. si l'Administration estime que ce délai est necessaire. 
(b) An Administration may, in areas where it considers it unreasonable or unnecessary for such apparatus to be carried, exempt any ships under 5.000 tons gross tonnage from this requirement. due regard being had to the fact that direction-finding apparatus is of value both as a navigational instrument and as an aid to locating ships, aircraft or survival craft.

\section{Regulation 13}

\section{Manning}

The Contracting Governments undertake, each for its national ships, to maintain, or, if it is necessary, to adopt, measures for the purpose of ensuring that, from the point of view of safety of life at sea, all ships shall be sufficiently and efficiently manned.

\section{Regolation 14}

\section{Aids 10 Navigation}

The Contracting Governments undertake to arrange for the establishment and maintenance of such aids to navigation, including radio beacons and electronic aids as, in their opinion, the volume of traffic justifies and the degree of risk requires, and to arrange for information relating to these aids to be made available to all concerned.

\section{Regulation 15}

\section{Search and Rescue}

(a) Each Contracting Government undertakes to ensure that any necessary arrangements are made for coast watching and for the rescue of persons in distress at sea round its coasts. These arrangements should include the establishment. operation and maintenance of such maritime safety facilities as are deemed practicable and necessary having regard to the density of the seagoing traffic and the navigational dangers and should, so far as possible, afford adequate means of locating and rescuing such persons.

(b) Each Contracting Government undertakes to make available information concerning its existing rescue facilities and the plans for changes therein, if any.

\section{Regulation 16}

\section{Life-Saving Signals}

The following signals shall be used by life-saving stations when communicating with ships in distress and by ships in distress when communicating with life-saving stations:-

(a) Replies from shore station 10 distress signals made by a ship :-

\section{Signal}

-By day-White smoke signal.

By night-White star rocket.

\section{Signification}

"You are seen-assistance will be given as soon as possible." 
(b) Toute Administration peut, dans les zones où elle juge qu'il ne serait ni raisonnable ni nécessaire d'imposer cet appareil, dispenser de ces prescriprions tous les navires de moins de 5.000 tonneaux de jauge brute, compte düment tenu du fait que le radicgoniomètre constitue une aide précieuse, tant comme instrument de navigation que comme moyen de déterminer la position de navires, d'avions ou d'embarcations rescapées.

\section{Reyle 13 \\ Equipage}

Les Gouvernements contractants s'engagent, en ce qui concerne leurs navires nationaux, à conserver ou, si c'est nécessaire, à adopter toute mesure ayant pour objet de s'assurer qu'au point de vue de la sécurité en mer, tous les navires aient à bord un équipage suffisant en nombre et en qualité.

\section{Règle 14}

\section{Aides à la navigation}

Les Gouvernements contractants conviennent d'assurer l'installation et l'entretien d'aides à la navigation, y compris les radiophares et les appareils électroniques, le long de leurs côtes dans la mesure où, à leur avis, ces mesures se justifient par l'intensité de la navigation et par le degré de risque : ils conviennent également d'assurer que les renseignements relatifs d ces aides seront mis à la disposition de tous les intéressés.

\section{Règle 15}

\section{Recherche et sauverage}

(a) Tout Gouvernement contractant s'engage à assurer que toutes les dispositions nécessaires seront prises pour la veille sur côtes et pour le sauvetage des personnes en détresse en mer au large de ses côtes. Ces dispositions doivent comprendre l'établissement, l'utilisation et l'entretien de toutes installations de sécurité maritime jugées pratiquement réalısables et nécessaires, eu égard à l'intensité du trafic en mer et aux dangers de la navigation, et doivent, autant que possible. fournir des moyens adéquats pour repérer et sauver les personnes en détresse.

(b) Chaque Gouvernement contractant s'engage à fournir les renseignements concernant les moyens de sauvetage dont il dispose, et, le cas échéant. les projets de modification auxdits moyens.

\section{Règle 16 \\ Signaux des stations de sauverage}

Les signaux suivants devront être employés par les stations de sauvetage dans leurs communications avec les navires en détresse et par les navires en détresse dans leurs communications avec les stations de sauvetage.

(a) Réponses des stations cótières aux signaux de détresse émis par un navire:

\section{Signal}

De jour-signal à fumée blanche

De nuit-fusée à étoiles blanches

\section{Signification}

"Nous vous voyons-secours vous sera porté aussitôt que possible". 
(b) Landing signals for the guidance of small boats bringing away the crew of a wrecked ship :-

Signal

\section{Signification}

-By day-Vertical motion of a white flag or the arms.

By night-Vertical motion of a white light or flare. A range (indication of direction) may be given by placing a steady white light or flare lower and in line with the observer.

"This is the best place to land."

-By day-Horizontal motion of a white flag or arms extended horizontally.

By night-Horizontal motion of a white light or Rare.

- By day-Horizontal motion of a white flag, followed by the placing of the white flag in the ground and the carrying of another white flag in the direction to be indicated.

By nigbt-Horizontal motion of a white light or flare, followed by the placing of the white light or flare on the ground and the carrying of another white light or flare in the direction to be indicated.

(c) Signals to be employed in connection with the use of shore life-saving apparatus :-

Signal

"Landing here highly dangerous."

“Landing here highly dangerous. A more favourable location to land is in the direction indicated."

-By day-Vertical motion of a white flag or the arms.

By night-Vertical motion of a white light or flare.

Signification

In general- " Affirmative." Specifically:-

"Rocket line is held."

"Tail block is made fast."

"Hawser is made fast."

"Man is in the breeches buoy."

"Haul away."

-By day-Horizontal motion of a white flag or arms extended horizontally.

By night-Horizontal motion of a white light or flare.

In general- “ Negative."

Specifically:-

"Slack away."

"Avast hauling."

\section{Regulation 17}

\section{Pilot Ladders}

All ships engaged on voyages in which pilots are likely to be embarked should comply with the following requirements respecting pilot ladders:-

(a) The ladder should be kept in good order and used as far as possible only for embarking and disembarking pilots and other officials while a ship is arriving at or leaving a port. 
(b) Signaux de déharquement destine's ì guider les emburcations irunsporlam l'équipage d'un navire naufragé:

De jour-mouvement vertical d'un pavillon blanc ou des bras.

De nuit-mouvement vertical d'un feu blanc ou d'une flamme blanche. Une ligne de repère (indication de direction) peutêtreétablie en plaçant une lumière ou un feu blanc stable plus bas et en ligne droite avec l'observateur.

De jour-nouvement horizontal d'un drapeau blanc ou des bras étendus horizontalement.

De nuit-mouvement horizontal d'une lumière ou d'un feu blanc.

De jour-mouvement horizontal d'un drapeau blanc, le drapeau étant ensuite piqué dans la terre, et un deuxième drapeau blanc dirigé vers la direction à indiquer.

De nuit-mouvement horizontal d'une lumière ou d'un feu blanc, le feu ou la lumière étant ensuite posé à terre et un autre feu blanc ou lumière étant transporté dans la direction à suivre.

"Cet emplacement est le meilleur endroit oú déharquer."

" 11 est extrêmement dangereux de débarquer ici."

" ll est extrêmement dangereux de débarquer ici. Un emplacement plus favorable au débarquement se trouve dans la direction indiquée."

(c) Signuux d̀ employer en liaison avec l'urilisation d'engins de sauverage ajant leur base sur la côte:

De jour-mouvement vertical d'un drapeau blanc ou des bras.

De nuit-mouvement vertical d'une lumière ou d'un feu blanc.

De jour-mouvement horizontal d'un drapeau blanc ou des bras étendus horizontalement.

De nuit-mouvement horizontal d'une lumière ou d'un feu blanc.
En général-" affirmatif."

Diune manière particulière:

" L'amarre est tenue."

"La poulie à fouet est amarrée."

"Le câble est amarrí."

" ll y a un homme dans la bouée culotte."

"Vire."

En général-“" négatif."

D'une manière particulière:

"Relâchez les amarres."

" Tiens bon virer."

\section{Règle 17}

\section{Echelles de pilure}

Tous les navires effectuant des voyages au cours desquels il ist probable qu'ils auront à embarquer des pilotes devront se conformer aux prescriptions suivantes en ce qui concerne les échelles de pilote:

(a) L'échelle doit être maintenue en bon état et dans la mesure du possible n'être employée que pour l'embarquement et le débarquement des pilotes et autres officiels lorsqu'un navire entre clans un port ou prend la mer. 
(b) The ladder should be of adequate length and strength.

(c) The treads should be of adequate width.

(d) Two man-ropes, properly secured, should, where circumstances so require, be used in conjunction with the ladders.

(e) Arrangements should be such that the pilot can safely pass from the head of the ladder to the ship's deck.

(f) Spreaders at suitable intervals should be provided, if necessary, to prevent the ladder twisting.

(g) At nigbt. a light shining overside should be available and used. 
(b) L'échelle sera de longueur et de solidité suffisantes.

(c) Les échelons seront de largeur suffisante.

(d) Deux tireveilles solidement assujetties seront, lorsque les circonstances le demandent, employées en même temps que les échelles.

(e) Des dispositions seront prises pour que le pilote puisse passer sans danger du haut de l'échelle sur le pont du navire.

(f) Des traverses placées à intervalles raisonnables seront installées, le cas échéant, pour empêcher l'échelle de tourner.

(g) De nuit, on devra tenir prêt et employer un fanal projetant de la lumière hors du bord. 
CHAPTER VI.-CARRIAGE OF GRAIN AND DANGEROUS GOODS

\section{Regulation 1 \\ Application}

Unless expressly provided otherwise, this Chapter applies to ships to which the present Regulations apply.

\section{Regulation 2}

\section{Carriage of Grain}

(a) The term "grain" includes wheat, maize (corn), oats, rye, barley, rice, pulses, and seeds.

(b) Where grain is loaded in a ship, all necessary and reasonable precautions shall be taken to prevent the grain from shifting.

(c) Any compartment which is entirely filled with loose grain in bulk shall be:-

(i) fed by properly constructed feeders which shall contain not less than $2 \frac{1}{2}$ per cent. nor more than 8 per cent. of the capacity of the compartment served, and

(ii) divided by a longitudinal bulkhead or shifting boards, which shall be properly secured and fitted grain tight with proper fillers (fillings) between the beams. In holds such shifting boards shall extend downwards from the underside of the deck to a distance of at least one-third of the depth of the hold or 8 feet. whichever is the greater. In 'tween deck compartments they shall extend from deck to deck. In all cases they shall extend to the top of the feeders of the hold or compartment in which they are situated.

(d) In any conpartment which is partially filled with loose grain in bulk. the grain shall be levelled and topped off with bagged grain or other suitable cargo extending to a height of not less than 4 feet above the top of the loose grain in bulk and supported on suitable platforms laid over the whole surface of the loose grain in bulk. In addition, the compartment shall be divided by a longitudinal bulkhead or shifting boards in line with the keel which shall extend from the bottom of the hold or deck as the case may be to 3 height sufficient to prevent the shifting of the loose grain in bulk. The fitting of a longitudinal bulkhead or shifting boards shall not be required if the grain in bulk does not exceed one-third the capacity of the compartment or, in the case of a compartment divided by a shaft tunnel, one-half the capacity of that compartment.

(e) Loose grain in bulk other than oats, light barley, and cotton seed shall not be carried in the 'tween decks of a two-deck ship, or in the uppermost 'tween decks of ships having more than two decks, except in properly constructed feeders as necessary for feeding the lower compartments. Loose grain in bulk may be carried in positions not otherwise permitted under this Regulation provided that:-

(i) It is carried in one or more bins, which shall be properly constructed and provided with feeders in accordance with the provisions of paragraph $(c)(i)$. 


\title{
CHAPITRE VI.-TRANSPORT DE GRANS ET DE MARCHANDISES DANGEREUSES
}

\author{
Règle I \\ Applicarion
}

Sauf dispositions expresses contraires, ce Chapitre s'applique à tous les navires soumis à l'application des présentes Règles.

\section{Règle 2}

Transpors de Cirain

(a) Le terme "grain" comprend le blé, le maïs ("corn"), l'avoine, le seigle, l'orge, le riz, les légumes secs et les graines de semences.

(b) Lorsque du grain est chargé sur un navire, toutes précautions raisonnables et nécessaires doivent être prises pour empêcher le ripage de la cargaison.

(c) Tout compartiment entièrement rempli de grain en vrac doit être:

(i) alimenté par des "feeders" de construction adéquate qui ne contiendront pas moins de $2 \frac{1}{2}$ pour cent ni plus de 8 pour cent de la capacité. du compartiment desservi, et

(ii) divisé par une cloison longitudinale ou des bardis qui doivent étre solidement assujettis et rendus étanches au grain par des remplissages convenables placés entre les barrots. Dans les cales ces bardis doivent s'étendre, vers le bas, à partir du dessous du pont jusqu'à une distance d'au moins un tiers de la profondeur de la cale ou de $2 \mathrm{~m} .440$ (ou 8 pieds), la plus grande de ces deux distances devant être adoptée. Dans les compartiments d'entrepont, ils doivent s'étendre de pont à pont. Dans tous les cas ils doivent s'étendre jusqu'à la surface supérieure du "feeder" de la cale ou du compartiment dans lequel ils se trouvent.

(d) Dans tout compartiment partiellement rempli de grain en vrac, le grain sera nivelé et couvert de grain en sacs ou autres marchandises appropriées jusqu'à une hauteur d'au moins $1 \mathrm{~m} .220$ (ou 4 pieds) au-dessus de la surface du grain en vrac; ce grain en sacs ou ces marchandises seront placées sur des planchers appropriés disposés sur toute l'étendue de la surface du grain en vrac. En outre ce compartiment doit être divisé par une cloison longitudinale ou des bardis placés parallèlement à la quille, qui iront du fond de la cale ou du pont, selon le cas, jusqu'à une hauteur suffisante pour empêcher le ripage du grain en vrac. L'installation d'une cloison longitudinale ou de bardis ne doit pas être exigée si le volume de grain en vrac ne dépasse pas le tiers de la capacité du compartiment ou, dans le cas d'un compartiment divisé par un tunnel, la moitié de la capacité de ce compartiment.

(e) 11 ne sera pas transporté de grain en vrac autre que de l'avoine, de l'orge léger ou des graines de coton, dans l'entrepont d'un navire à deux ponts ou dans l'entrepont supérieur des navires ayant plus de deux ponts, si ce n'est dans des "feeders" convenablement construits pour alimenter les compartiments inférieurs. Il peut être transporté du grain en vrac dans les locaux autres que ceux autorisés aux termes de la présente Règle, à condition:

(i) qu'il soit transporté dans une ou plusieurs sections spécialement construites à cet effet et munies de "feeders" conformément aux prescriptions du paragraphe $(c)(i)$. 
(ii) The hold or compartment below the bin or bins is properly battened down, clear of the feeder to such hold or compartment.

(iii) The quantity of grain so carried does not exceed the capacity fixed by the Administration.

(f) Each Administration may, if it considers that the sheltered nature and conditions of the voyage are such as to render the application of any of the requirements of paragraphs $(c)$ and $(d)$ of this Regulation unreasonable or unnecessary, exempt from those particular requirements individual ships or classes of ships.

\section{Regnlation 3}

\section{Carriage of Dangerous Goods}

(a) The term "dangerous goods" includes:-

(i) explosives;

(ii) compressed, liquefied and dissolved gases;

(iii) corrosives;

(iv) poisons;

(v) substances giving off inflammable vapours;

(vi) substances which become dangerous by interaction with water or air;

(vii) strong oxidising agents;

(viii) substances which are liable to spontaneous combustion;

(ix) any other substance which experience has shown, or may show, to be of such a dangerous character that the provisions of this Regulation should apply to it.

(b) The carriage of dangerous goods is prohibited except in accordance with the provisions of this Regulation.

(c) Explosives other than the following may not be carried on passenger ships :-

(i) safety cartridges and safety fuses:

(ii) small quantities of explosives not exceeding $20 \mathrm{lbs}$. in the aggregate;

(iii) explosives up to a total of $10 \mathrm{cwt}$. in approved packages on the deck of a passenger ship on a short voyage.

(d) Notwithstanding the provisions of paragraph (c), explosives may be carried on passenger ships on which there are special approved safety measures.

(e) On ships carrying inflammable liquids adequate precautions shall be taken against fire or explosion.

(j) Substances which are liable to spontaneous combustion (including fodder and other vegetable products especially if damp) shall not be carried unless adequate precautions have been taken to prevent outbreak of fire.

(g) Dangerous goods tendered to a ship for transportation shall be accompanied by a written statement by the shipper correctly describing the shipment according to the classification used in paragraph $(a)$ of this Regulation.

(h) Except for parcels of mixed chemicals in limited quantities, shipments of dangerous goods shall be marked with a distinctive label or stencil which 
(ii) que la cale ou le compartiment situés sous le ou les sections soient convenablement condamnés en laissant dégagé le "feeder" desservant cette cale ou ce compartiment.

(iii) que la quantité de grain ainsi transportée ne dépasse pas la capacité fixée par l'Administration.

( $\left.\int\right)$ Chaque Administration, si elle estime que le caractère abrité du voyage et les couditions de ce voyage sont tels que l'application de l'une quelconque des dispositions des paragrapbes $(c)$ et $(d)$ de la présente Règle n'est ni raisonnable ni nécessaire, peut dispenser de ces dispositions particulières certains navires ou certaines classes de navires.

\section{Règle 3}

\section{Transport de Marchandises dangereuses}

(a) Le terme " marchandises dangereuses" comprend:

(i) les explosifs;

(ii) les gaz comprimés, liquétiés et dissous;

(iii) les substances corrosives;

(iv) les poisons;

(v) les substances dégageant des vapeurs inflammables:

(vi) les substances qui deviennent dangereuses au contact de l'air ou de l'eau;

(vii) les oxydants puissants;

(viii) les substances susceptibles de combustion spontanée;

(ix) toute autre substance que l'expérience a révélée, ou pourrait révéler, de nature si dangereuse que les dispositions de la présente Règle devraient s'y appliquer.

(b) Le transport de marchandises dangereuses est interdit, à moins qu'il ne soit effectué conformément aux dispositions de la présente Règle.

(c) Aucun explosif autre que ceux désignés ci-après ne peut être transportè à bord des navires à passagers:-

(i) cartouches et fusées de sûreté;

(ii) petites quantités d'explosifs ne dépassant pas 9 kilos 20 livres anglaises), au total;

(iii) 450 kilos (10 cwt.) a u plus d'explosifs quelconques, dans des emballages approuvés, sur le pont d'un navire à passagers efiectuant un voyage court;

(d) Nonobstant les dispositions du paragraphe (c), les explosifs peuvent être transportés sur des navires à passagers à bord desquels sont appliquées de mesures de sécurité spéciales approuvées.

(e) Toutes précautions nécessaires contre l'incendie et les explosions seront prises à bord de tout navire transportant des liquides inflammables.

$(f)$ Substances susceptibles de combustion spontanée (y compris le fourrage et autres produits végétaux, particulièrement s'ils sont humides) ne doivent être transportées que si toutes précautions nécessaires ont été prises pour éviter qu'un incendie ne se déclare.

(g) Toutes marchandises dangereuses amenées à un navire pour être transportées devront être accompagnées d'une déclaration écrite de l'expéditeur contenant une description exacte du chargement d'après la classification employée au paragraphe (a) de la présente Règle.

(h) Excepté en ce qui concerne les colis de produits cbimiques divers en petites quantités, les chargements de marcbandises dangereuses doivent porter 
shall indicate their dangerous character. Each package of the shipment shall be so marked except in the case of a large shipment which can be stowed and identified as a unit.

(i) Each ship carrying dangerous goods shall carry a special list setting forth. in accordance with paragraph $(a)$ of this Regulation, the dangerous goods on board.

(j) Each Contracting Government shall issue, or cause to be issued. detailed rules to supplement the provisions of this Regulation. Such detailed rules shall provide for the packing and stowage of dangerous goods when carried with other commodities, and for the stowage of various categories of dangerous goods.

(k) The nrovisions of this Regulation do not apply to ship's stores and equipment. 
une marque ou une étiquette distinctive indiquant la nature dangereuse de ces articles. Chacun des colis du chargement doit être ainsi marqué, sauf dans le cas d'un chargement important, pouvant être arrimé et identifié comme un seul lot.

(i) Chaque navire transportant des marchandises dangereuses doit être porteur d’une liste spéciale, les énumérant, conformément au paragraphe $(a)$ de la présente Règle.

( $j$ ) Chaque Gouvernement contractant devra faire paraître, ou provoquer la parution d'un règlement détaillé destiné à compléter les dispositions de la présente Règle. Ce règlement détaillé fxxera l'emballage et la façon d'arrimer des marchandises dangereuses lorsqu'elles sont transportées avec d'autres produits, ainsi que les régles d'arrimage de différentes catégories de marchandises dangereuses.

(k) Les dispositions de la présente Règle ne s'appliquent pasaux provisions de bord ni au matériel d'armement des navires. 


\section{APPENDIX}

Form of Safely Cerifficate for Passenger Ships

\section{SAFETI' CERTIFICATE}

(Official Seal)

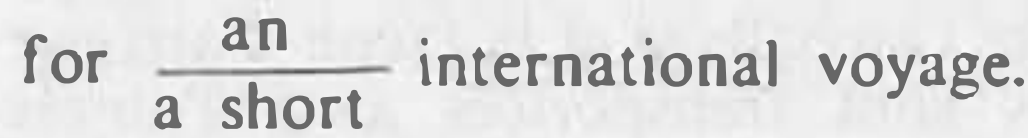

Issued under the provisions of the

International, Convention for the Safety of Life at Sea, 1948

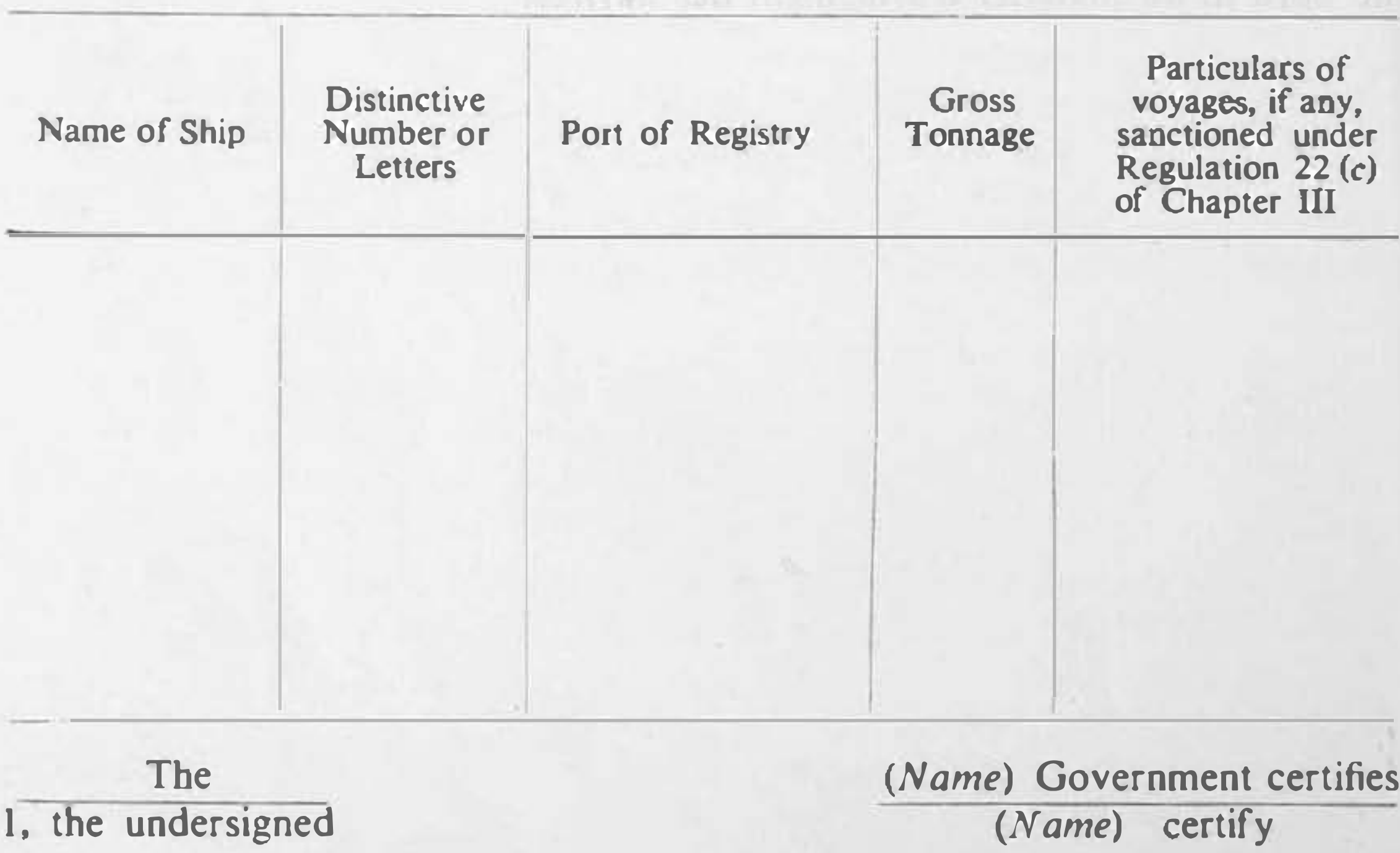

1. That the above-mentioned ship has been duly surveyed in accordance with the provisions of the Convention referred to above.

11. That the survey showed that the ship complied with the requirements of the Regulations annexed to the said Convention as regards:-

(1) the structure, main and auxiliary boilers and machinery;

(2) the watertight subdivision arrangements and details;

(3) the following subdivision loadlines:-

\begin{tabular}{c|c|c}
\hline $\begin{array}{c}\text { Subdivision loadlines assigned and } \\
\text { marked on the ship's side at } \\
\text { amidships (Regulation } 10 \text { of } \\
\text { Chapter II) }\end{array}$ & Freeboard & $\begin{array}{c}\text { To apply when the spaces in which } \\
\text { passengers are carried include the } \\
\text { following alternative spaces }\end{array}$ \\
\hline C. 1 & $\ldots$ & $\ldots$ \\
C. 2 & $\ldots$ & $\ldots$ \\
C. 3 & $\ldots$ & $\ldots$
\end{tabular}


APPENDICE

Modèle de Cerrifical de Sécurilé pour Navires à Passagers CERTIFICAT DE SECCURITÉ

(Cacker Officiel)

(Nationalité)

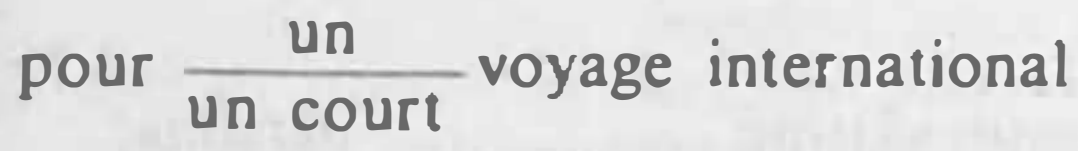

Délivré en vertu des dispositions de la

Convention Internationale pour la Sauiegarde de la Vie Humaine en Mer, 1948

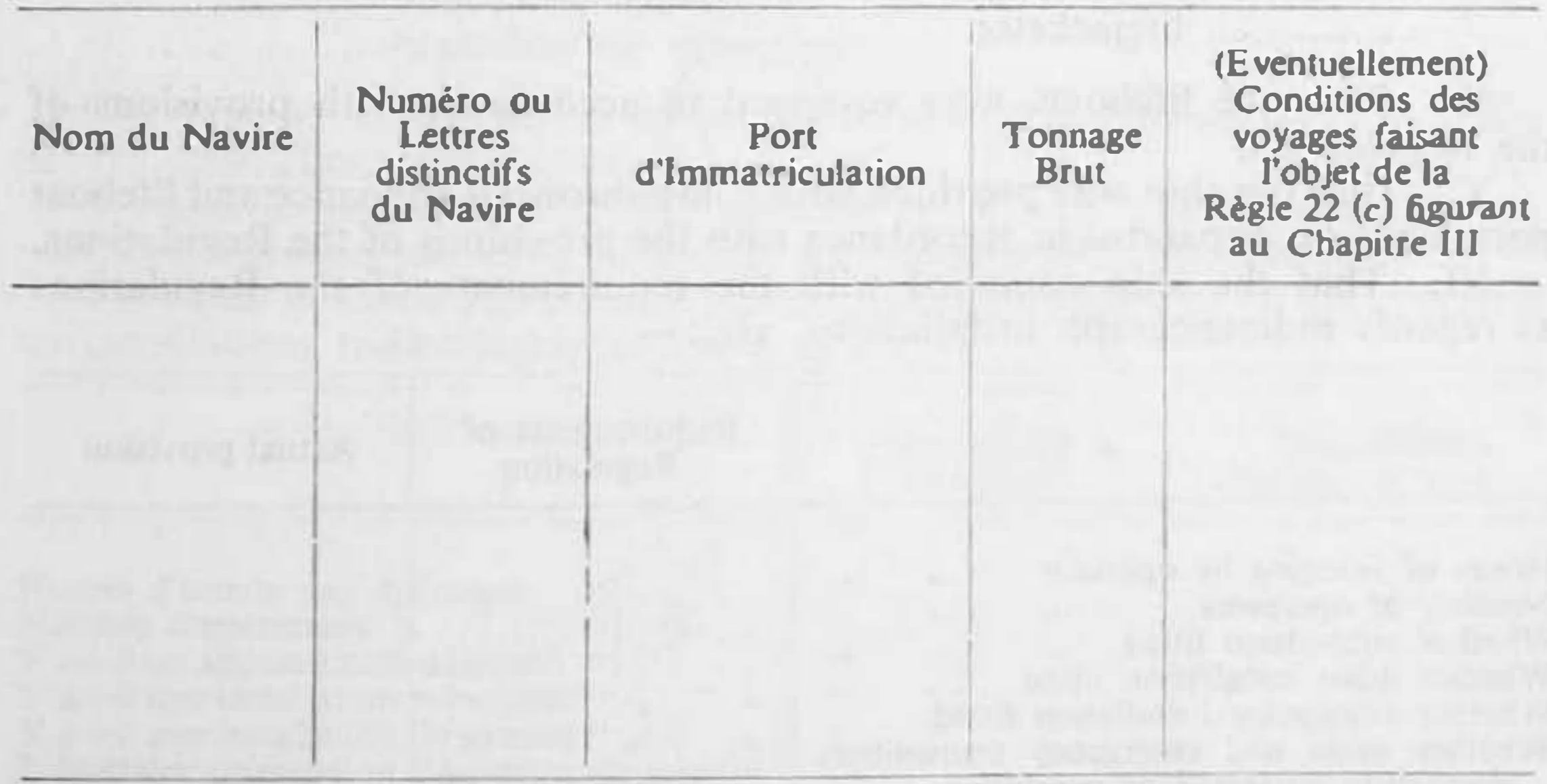

Le Gouvernement

Je, soussigné

(Nom) certifie

(Nom) certifie

1. Que le navire susvișé a été dûment visité conformément aux dispositions de la Convention Internationale précitée.

II. Qu'à la suite de cette visite, il a été constaté que le navire satisfait aux prescriptions des Règles annexées à la dite Convention en ce qui concerne:

(1) La structure, les machines et les chaudières principales et auxiliaires;

(2) les dispositions et les détails relatifs au compartimentage étanche;

(3) les lignes de charge de compartimentage suivantes:

\begin{tabular}{c|c|c}
$\begin{array}{c}\text { Lignes de charge de compartimentage } \\
\text { déterminés et marquées sur la } \\
\text { muraille au milieu du navire } \\
\text { (Règle JO figurant au Chapitre II } \\
\text { de la Convention) }\end{array}$ & Franc-bord & $\begin{array}{c}\text { A utiliser quand les espaces affectés } \\
\text { aux passagers comprennent les } \\
\text { volumes suivants pouvant étre } \\
\text { oocupés soit par des passagers, } \\
\text { soit par des marchandises }\end{array}$ \\
\hline C. 1 & $\ldots$ & $\ldots$ \\
C. 2 & $\ldots$ & $\ldots$ \\
C. 3 & $\ldots$ & $\ldots$ \\
\hline
\end{tabular}


III. That the life-saving appliances provide for a total number of .........................................persons and no more, viz.:-
lifeboats (including ................. motor lifeboats or mechanically propelled lifeboats) capable of accom- modating ............. persons, and ............ motor lifeboats fitted with radiotelegraph installation and searchlight (included in the total lif eboats shown above), requiring .............. certificated lif eboatmen;

liferafts capable of accommodating

persons;

buoyant apparatus capable of supporting

persons;

............... lif ebuoys;

lifejackets;

IV. That the lifeboats were equipped in accordance with provisions of the Regulations.

V. That the ship was provided with a line-throwing appliance and lifeboat portable radio apparatus in accordance with the provisions of the Regulations.

VI. That the ship complied with the requirements of the Regulations as regards radiotelegraph installations, viz.:-

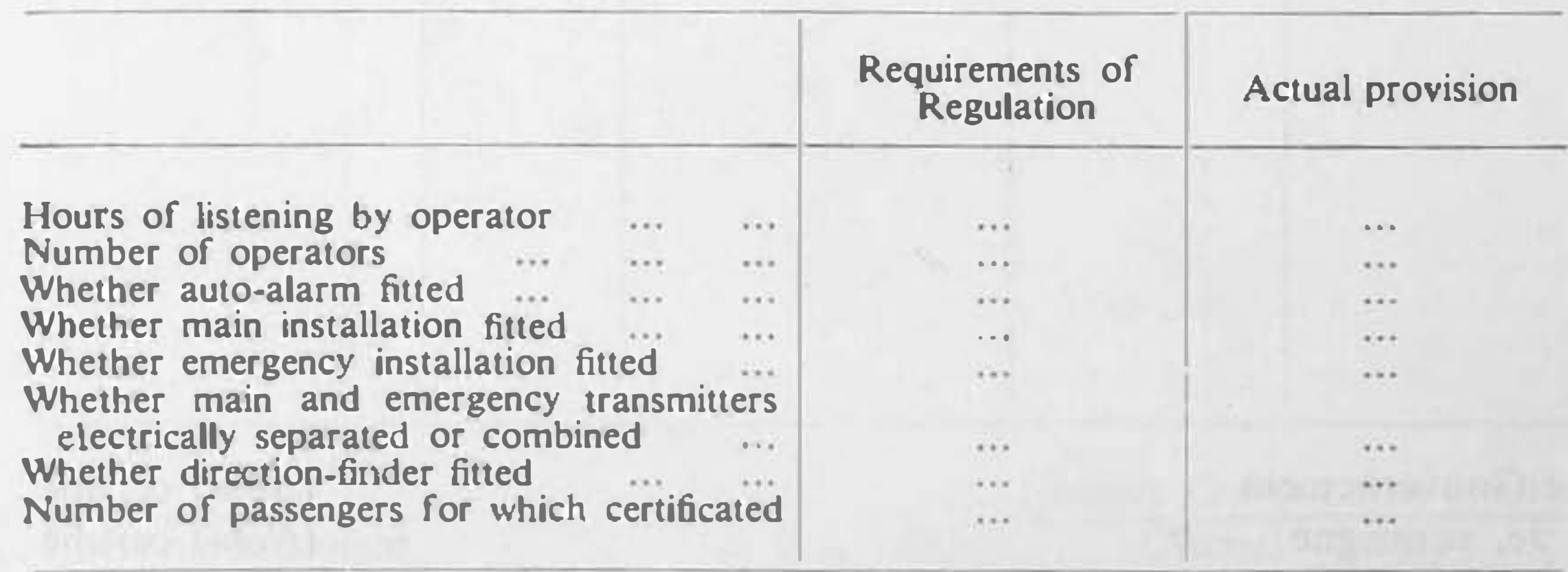

VII. That the ship complied with the requirements of the Regulations, as regards fire-detecting and fire-extinguishing appliances and was provided with navigation lights and shapes, and means of making sound signals and distress signals, in accordance with the provisions of the Regulations and also the International Collision Regulations.

VIII. That in all other respects the ship complied with the requirements of the Regulations, so far as these requirements apply thereto.

This certificate is issued under the authority of the

Government. It will remain in force until

Issued at

the

day of

19.

Here follow's the seal or signature of the authority entilled 10 issue the certificate.

(Seal)

If signed, the following paragraph is 10 be added:-

The undersigned declares that he is duly authorised by the said Government to issue this Certificate.

(Signature) 
III. Que les engins de sauvetage sont suffisants pour un nombre total maximum de personnes, à savoir:

embarcations de sauvetage (y compris

embarcations de sauvetage à moteur ou embarcations de sauvetage à propulsion mécanique) susceptibles de recevoir ............. personnes, et ............. embarcations de sauvetage à moteur munies d'une installation radiotélégraphique et d'un projecteur (compris dans le nombre total des embarcations de sauvetage ci-dessus mentionnées) exigeant .................. canotiers brevetés;

radeaux de sauvetage susceptibles de recevoir .............. personnes;

engins flottants susceptibles de supporter personnes;

bouées de sauvetage;

brassières de sauvetage.

IV. Que les embarcations de sauvetage sont pourvues du matériel prévu par les dispositions des Règles.

V. Que le navire est muni d'un appareil lance-amarre et d'une installation radiotélégraphique portative répondant aux prescriptions des Règles.

VI. Que le navire répond aux prescriptions des Règles en ce qui concerne les installations radiotélégraphiques, à savoir:-

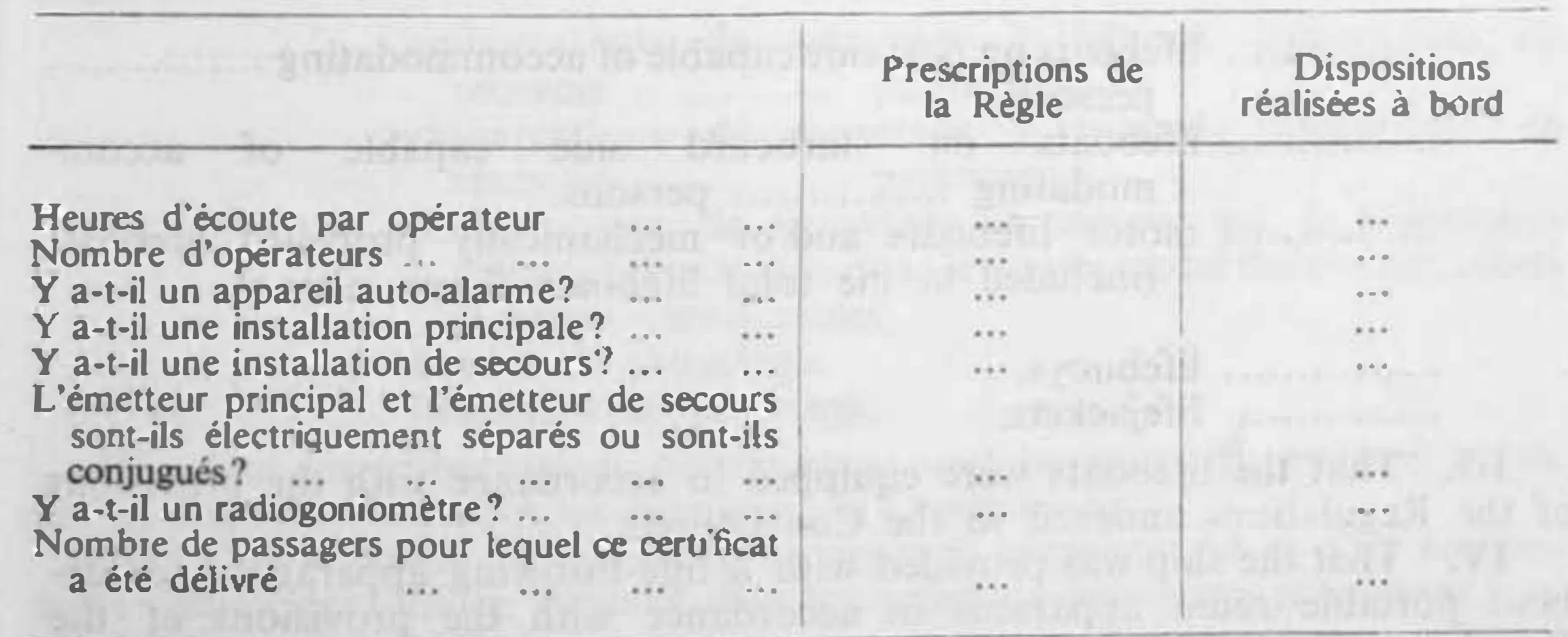

VII. Qu'à la suite de la visite, il a été constaté que le navire satisfait aux prescriptions des dites Règles en ce qui concerne les dispositifs de détection et dextinction de l'incendie, et qu'il est pourvu de feux et de marques de navigation, ainsi que des moyens d'émettre des signaux sonores et des signaux de détresse, conformément aux dispositions des Règles et à celles des Règles Internationales pour prévenir les Abordages en Mer.

VIII. Que le navire répond à toutes les autres prescriptions des Règles dans la mesure où elles lui sont applicables.

Ce certificat est délivré sous l'autorité du Gouvernement

Il est valable jusqu'au
Délivré à
, le

(Placer ici le cachet ou la signature de l'autorité chargée de la délivrance de ce cerfificat.)

(Cacher)

Si ce document est signé, le paragraphe suivant est ajouté:

Le soussigné déclare qu'il est dûment autorisé par le dit Gouvernement à délivrer le présent certificat.

(Signarure) 
Form of Cerlificate for Cargo Ships

\section{SAFETY EQUIPMENT CERTIFICATE}

(Official Seal)

Issued under the provisions of the

International Convention for the Safety of Ltre at Sea, 1948

\begin{tabular}{l|c|c|c} 
Name of Ship & $\begin{array}{c}\text { Distinctive } \\
\text { Number or } \\
\text { Letters }\end{array}$ & Port of Registry & Gross Tonnage \\
\hline
\end{tabular}

\section{The \\ 1 , the undersigned}

(N'ame) Government certifies (Name) certify

1. That the above-mentioned ship has been duly inspected in accordance with the provisions of the Convention referred to above.

11. That the inspection showed that the life-saving appliances provide for a total number of ............. persons and no more, viz.:-

lifeboats on port side capable of accommodating .............. persons.

lifeboats on starboard side capable of accommodating ............. persons.

motor lifeboats and/or mechanically propelled lifeboats (included in the total lifeboats shown above).

............. lifebuoys.

lifejackets.

III. That the lifeboats were equipped in accordance with the provisions of the Regulations annexed to the Convention.

IV. That the ship was provided with a line-throwing apparatus and lifeboat portable radio apparatus in accordance with the provisions of the Regulations.

V. That the inspection showed that the ship complied with the requirements of the said Convention as regards fire-extinguishing appliances and was provided with navigation lights and shapes and means of making sound signals and distress signals, in accordance with the provisions of the Regulations and the International Collision Regulations.

VI. That in all other respects the ship complied with the requirements of the Regulations so far as these requirements apply thereto.

This certificate is issued under the authority of the

Government. It will remain in force until

Issued at the day of

Here follow's the seal or signature of the authority entilled 10 issue the cerificate.

$$
\text { (Seal) }
$$

If signed, the following paragraph is 10 be added:-

The undersigned declares that he is duly authorised by the said Government to issue this Certificate.

(Signarure) 
Modèle de Cerlifical pour Navires de Charge

\section{CERTIFICAT DE SÉCURITÉ POUR LE MATÉRIEL D'ARMEMENT (Cacher Officiel) (Narionaliré)}

Délivré en vertu des dispositions de la

\section{Convention Internationale pour la Sauvegarde de la Vie Humaine en Mer, 1948}

\begin{tabular}{l|c|c|c}
\hline Nom du Navire & $\begin{array}{c}\text { Numéro ou } \\
\text { Lettres Distinctifs } \\
\text { du Navire }\end{array}$ & $\begin{array}{c}\text { Port } \\
\text { d'Immatriculation }\end{array}$ & Tonnage Brut \\
\hline
\end{tabular}

\section{Le Gouvernement}

Je, soussigné

(Nom) certifie

(Nom) certifie

1. Que le navire susvisé a été dūmeat visité conformément aux dispositions de la Convention précitée.

II. Qu'à la suite de cette visite, il a été constaté que les engins de sauvetage sont suffisants pour un nombre total maximum de .............. personnes, à savoir:

embarcations de sauvetage à bâbord susceptibles de recevoir .............. personnes.

embarcations de sauvetage à tribord susceptibles de recevoir .............. personnes.

embarcations de sauvetage à moteur oul à propulsion mécanique(compris dans le nombre total des embarcations ci-dessus mentionnées).

bouées de sauvetage.

.............. brassières de sauvetage.

IL. Que les embarcations de sauvetage sont pourvues du matériel prévu par les dispositions des Règles annexées à la Convention.

IV. Que le navire est pourvu d'un appareil lance-amarre et d'un équipement radiotélégraphique portatif d'embarcation de sauvetage répondant aux prescriptions des Règles.

V. Qu'à la suite de la visite il a été constaté que le navire satisfait aux prescriptions des Règles en ce qui concerne les dispositifs d'extinction de l'incendie, et qu'il est pourvu de feux et de marques de navigation, ainsi que des moyens d'émettre des signaux sonores et des signaux de détresse, conformément aux dispositions des Règles et à celles des Règles Internationales pour prévenir les Abordages en Mer.

V. Que le navire répond à toutes les autres prescriptions des Règles, dans la mesure où elles lui sont applicables.

Ce certificat est délivré sous l'autorité du Gouvernement Il est valable jusqu'au

Délivré à , le

(Placer ici le cachet ou la signarure de l'autorité chargée de la délivrance de ce certificar.)

(Cachet)

Si ce document est signé, le paragraphe suivant est ajouté:

Le soussigné déclare qu'il est dûment autorisé par le dit Gouvernement à délivrer le présent certificat. 


\section{Form of Safety Radiotelephony Certificate}

\section{SAFETY RADIOTELEPHONY CERTIFICATE}

(Official Seal)

Issued under the provisions of the

International Convention for the Safeiy of Life at Sea, 1948

\begin{tabular}{c|c|c|c}
\hline Name of Ship & $\begin{array}{c}\text { Distinctive } \\
\text { Number or } \\
\text { Letters }\end{array}$ & Port of Registry & Gross Tonnage \\
\hline & & & \\
\hline The & (Name) Government certifies \\
\hline I, the undersigned, & (Name) certify
\end{tabular}

That the above-mentioned ship complies with the provisions of the Regulations annexed to the Convention referred to above as regards Radiotelephony:-

\begin{tabular}{|c|c|c|}
\hline & $\begin{array}{l}\text { Requirements of } \\
\text { Regulations }\end{array}$ & Actual provision \\
\hline Hours of listening by & & \\
\hline Number of operators & $\ldots$ & $\ldots$ \\
\hline
\end{tabular}

This certificate is issued under the authority of the Government. It will remain in force until

Issued at the day of

Here follows the seal or signature of the authority entitled 10 issue this certificate.

If signed, the following paragraph is to be added:-

The undersigned declares that he is duly authorised by the said Government to issue this Certificate. 
Modèle de Certificat de Sécurité Radiotéléphonique

\section{CERTIFICAT DE SÉCURITÉ RADIOTÉLÉPHONIQUE}

(Cachet Officiel)

(Nationalité)

Délivré en vertu des dispositions de la

Convention Internationale pour la Sauvegarde de la

VIE HumanNe en MER, 1948

\begin{tabular}{l|c|c} 
Nom du Navire & $\begin{array}{c}\text { Numéros ou } \\
\text { Lettres Distinctifs } \\
\text { du Navire }\end{array}$ & $\begin{array}{c}\text { Port } \\
\text { d'Immatriculation }\end{array}$
\end{tabular}

Le Gouvernement

(Nom) certifie

Je, soussigné

(Nom) certitie

Que le navire susvisé satisfait aux dispositions des Règles annexées à la Convention Internationale précitée en ce qui concerne la Radiotéléphonie:

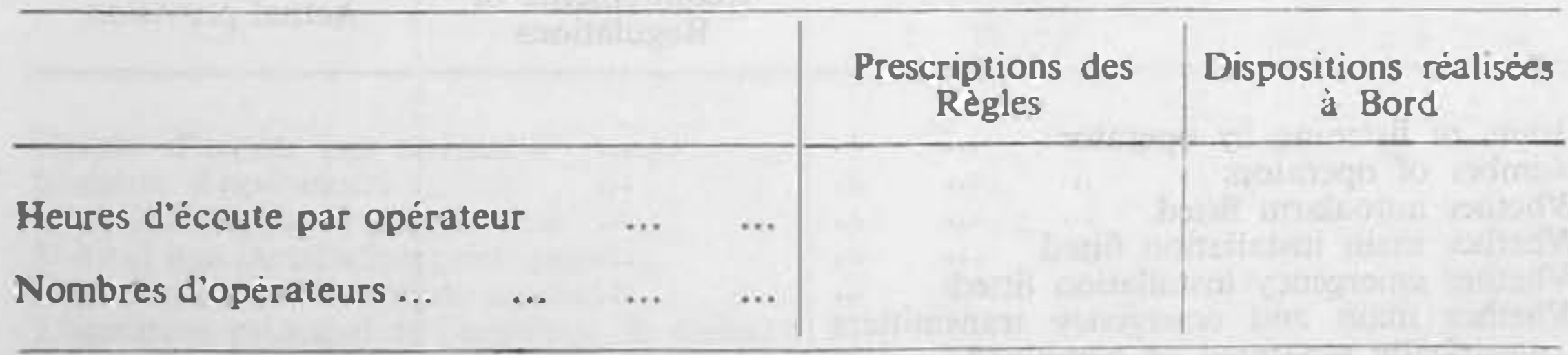

Ce certificat est délivré au nom du Gouvernement

Il est valable jusqu'au

Délivrè à , le

Placer ici le cachet ou la signature de l'autorité chargée de délivrer ce certificat.

(Cachel)

Si le document est signé, le paragraphe suivant est ajouté:

Le soussigné déclare qu'il est dûment autorisé par le dit Gouvernement à délivrer ce certificat.

(Signature) 
Form of Safety Radiotelegraphy Certificate

\section{SAFETY RADIOTELEGRAPHY CERTIFICATE}

(Official Seal)

(Country)

Issued under the provisions of the

International Convention for the Safety of Life at Sea, 1948

\begin{tabular}{l|c|c|c|}
\hline Name of Ship & $\begin{array}{c}\text { Distinctive } \\
\text { Number or } \\
\text { Letters }\end{array}$ & Port of Registry & Gross Tonnage \\
\hline The the undersigned, & (Name) Government certifies \\
\hline Tame) certify
\end{tabular}

That the above-mentioned ship complies with the provisions of the Regulations annexed to the Convention referred to above as regards Radiotelegraphy:-

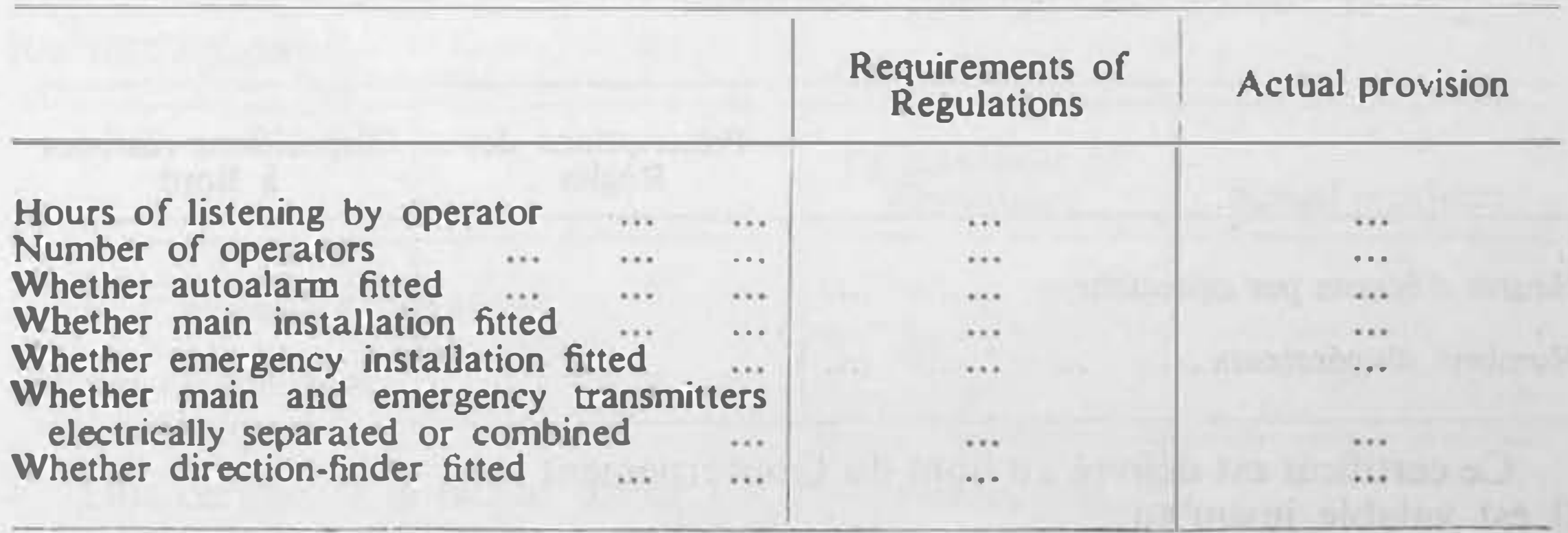

This certificate is issued under the authority of the Government. It will remain in force until

Issued at

the

day of

19 .

Here follows the seal or signature of the authority entirled to issue this cerlificate.

(Seal)

If signed, the following paragraph is 10 be added:-

The undersigned declares that he is duly authorised by the said Government 10 issue this Certificate. 
Modèle de certificat de Sécurité Radiotélégraphique

\section{CERTIFICAT DE SÉCURITÉ RADIOTÉLÉGRAPHIQUE}

(Cachet Officiel)

(Nationalite)

Délivré en vertu des dispositions de la

Convention Internationale pour la SAuvegarde de la Vie Humaine en Mer, 1948

Nom du Navire $\left|\begin{array}{c}\text { Numéro ou } \\ \text { Letores Distinctifs } \\ \text { du Navire }\end{array}\right| \begin{gathered}\text { Port } \\ \text { d'Immatriculation }\end{gathered} \mid$ Tonnage Brut

Le Gouvernement

Je, soussigné

(Nom) certitie

(Nom) certifie

Que le navire susvisé satisfait aux dispositions des Régles annexées à la Convention précitée en ce qui concerne la Radiotélégraphie:

\begin{tabular}{|c|c|c|}
\hline 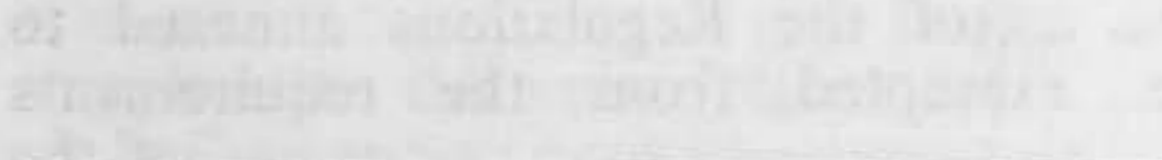 & $\begin{array}{c}\text { Prescriptions des } \\
\text { Regles }\end{array}$ & $\begin{array}{l}\text { Dispositions } \\
\text { réalisées à bord }\end{array}$ \\
\hline 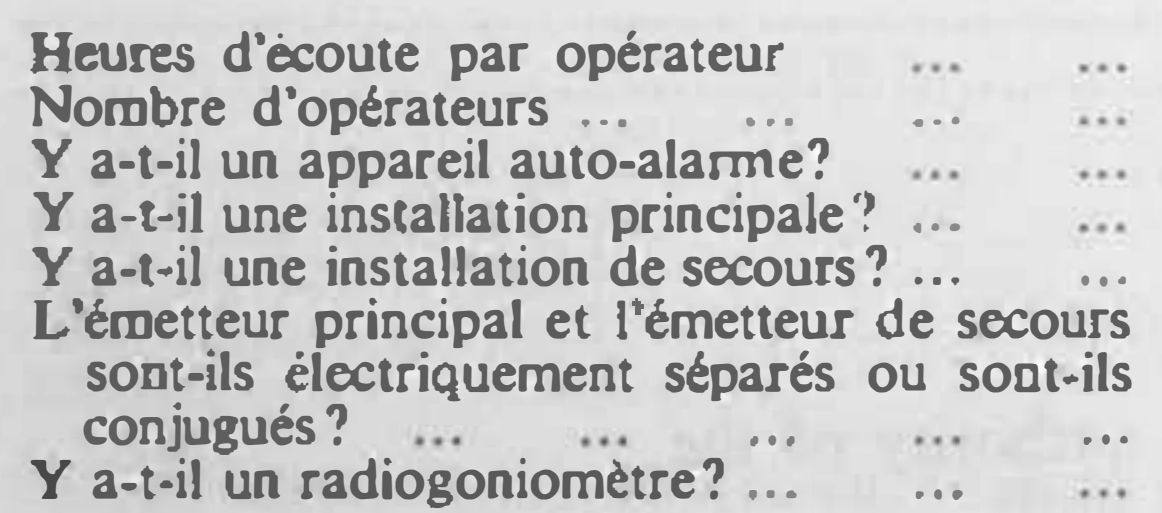 & $\begin{array}{l}\cdots \\
\cdots \\
\cdots \\
\cdots \\
\cdots \\
\cdots\end{array}$ & $\begin{array}{l}\ldots \\
\ldots \\
\ldots \\
\ldots \\
\ldots\end{array}$ \\
\hline
\end{tabular}

Ce certificat est délivré au nom du Gouvernement

Il est valable jusqu'au

Délivré à , le

(Placer ici le cachet ou la signature de l'autorité chargée de délivrer ce certificat.)

(Cachet)

Si ce document est signé, le paragraphe suivant est ajouté:

Le soussigné déclare qu'il est dûment autorisé par le dit Gouvernement à délivrer ce certificat. 


\section{Form of Exemption Cerlificate}

\section{EXEMPTION CERTIFICATE}

(Official Seal)

Issued under the provisions of the

International Convention for the Safety of Life at Sea, 1948

\begin{tabular}{l|c|c|c}
\hline Name of Ship & $\begin{array}{c}\text { Distinctive } \\
\text { Number or } \\
\text { Letters }\end{array}$ & Port of Registry \\
\hline & Gross Tonnage
\end{tabular}

The

I, the undersigned

(Name) Government certifies

(Name) certify

That the above-mentioned ship is, under the authority conferred by Regulation............. of Chapter............. of the Regulations annexed to the Convention referred to above, exempted from the requirements

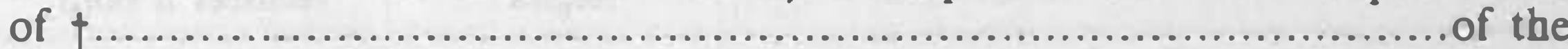
Convention on the voyages.

to

- Insert here the *

conditions, if any, on

which the exemption

certificate is granted.

This certificate is issued under the authority of the Government. It will remain in force until

Issued at the day of

Here follows the seal or signature of the authority entilled 10 issue this certificate.

If signed, the following paragraph is 10 be added:-

The undersigned declares that he is duly authorised by the said Government to issue this certificate.

(Signalure)

† Insert here references to Chapters and Regulations, specifying particular paragraphs. 


\section{Modèle de Cerrifical d'Exemprion}

\section{CERTIFICAT D'EXEMPTION}

(Cachet Officiel)

(Narionalité)

Délivré en vertu des dispositions de la

Convention Internationale pour la Sauvegarde de la Vie Humaine en Mer, 1948

\begin{tabular}{l|c|c|c}
\hline Nom du Navire & $\begin{array}{c}\text { Numéro ou } \\
\text { Lettres Distinctifs } \\
\text { du Navire }\end{array}$ & Tonnage Brut \\
\hline d'Immatriculation & & Tort
\end{tabular}

\section{Le Gouvernement}

Je, soussigné

(Nom) certifie (Nom) certifie

Que le navire susvisé est exempté, en vertu de la Règle Chapitre ............... des Règles annexées à la Convention précitée, de l'application des prescriptions de $†$ de la Convention pour les voyages de à.

* Indiquer ici les conditions, s'ilenexiste, sous lesquelles le certificat d'exemption est accordé.

Ce certificat est délivré au nom du Gouvernement Il est valable jusqu'au

Dé.ivré à , le

(Placer ici le cachet ou la signature de l'aurorité chargée de délivrer ce certificat.)

(Cachet)

Si le document est signé, le paragraphe suivant est ajouté:

Le soussigné déclare qu'il est dûment autorisé par le dit Gouvernement à délivrer ce certificat. 


\section{LIST OF ACCEPTANCES}

Date of deposil

United Kingdom

Canada

New Zealand

South Africa

India

Pakistan

Belgium

Denmark

France

Iceland

Israel

Italy

Japan

Netherlands

Norway

Philippine Republic

Portugal

Sweden

United States of America

Yugoslavia 30th September, 1949.

1st February. 1951.

29th December, 1949.

18th August. 1950.

19th November. 1952.

Ist February, 1951.

5th December, 1951.

15th October, 1951.

8th February, 1950.

19th October, 1950.

2nd July. 1952.

19th November, 1951.

23rd July, 1952.

18th April, 1950.

12th June. 1950.

2nd October. 1952.

30th November. 1950.

16th May, 1950.

Sth January, 1950.

13th November, 1951. 


\section{GOVERNMENT PUBLIGATIONS}

NAUTICAL ALMANAC AND ASTRONOMICAL EPHEMERIS

$$
\text { FOR } 1951
$$

Standard Edition, cloth cover ... out of print

Abridged Edition for the Use of Seamen $\quad . . \quad \ldots \quad \ldots \quad \ldots$ 6s. 0d. (6s. 6d.)

INSTRUCTIONS AS TO THE SURVEY OF LIFB SAVING APPLIANCES

1936. Reprinted $\overline{1951} \ldots$ 4s. 6d. (4s. 9d.) Supplement No. 1. 1936. Reprinted 1952 ... $\quad \ldots \quad \ldots . \quad$ 2s. 6d. (2s. 7 fd.)

THE MARINB OBSBRVBR

Published Quarterly $\ldots . \ldots$ 5s. 0d. (5s. 11d.) Annual Subscription ... $\quad$... 21s. Od. including postage

THE METEOROLOGICAL MAGAZINE

Published Monthly _.. ... 2s. 0d. (2s. 1 $1 \frac{1}{2}$ d.) Annual Subscription ... ... 25s. Od. including postage

Obrainable from

HER MAJESTY'S STATIONERY OFFICE LONDON W.c. 2 ... ... ... York House, Kingsway (Post Orders-P.O. Box No. 569, London, S.E.1.)

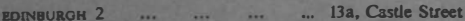

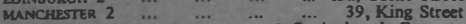
$\begin{array}{llllll}\text { CARDITF } & \ldots & \ldots & \ldots & \ldots & \text { I, St. Andrew's Cresceat }\end{array}$ $\begin{array}{llllll}\text { BELPAST } & \ldots & \ldots & \ldots & \ldots & 1, \text { St, } \\ \text { Ben, Chichester Street }\end{array}$ $\begin{array}{lllllll}\text { BeustoL } 1 & \ldots & \ldots & \ldots & \ldots & & \ldots \\ & \ldots & \ldots & \ldots & \ldots & \ldots & \ldots .\end{array}$ OR THROUGHANY BOOKSELLER 
PRNTED AND PUBLISHED BY MER MANESTY'S STATIONERY OFHCE

To be purchased from

York House, Kingsway, LONDON, w.c.2 423 Oxford Street, LONDON, w.1 P.O. BOX 569, LONDON, S.E.1

13a Castle Street, EOINBURGH, 2 i St. Andrew's Crescent, CARDIfF

39 King Stroet, MANCHISTER, 2 Tower Lane, BessTor, 1

2 Edmund Street, BRmingham, 380 Chichester Street, Belfast

or from any Bookseller

1953

Price 6s. 6d. net

PRINTED IN GREAT DRITAIN 